Historic, Archive Document

Do not assume content reflects current scientific knowledge, policies, or practices. 



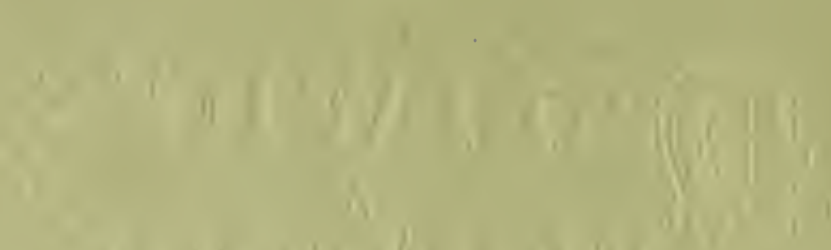

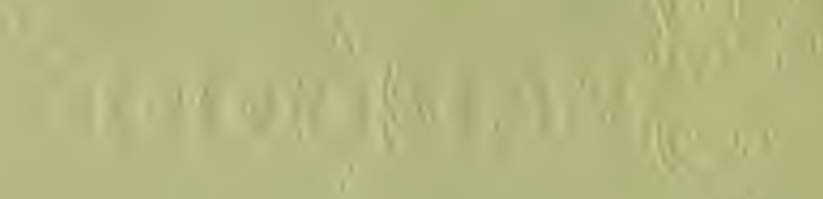




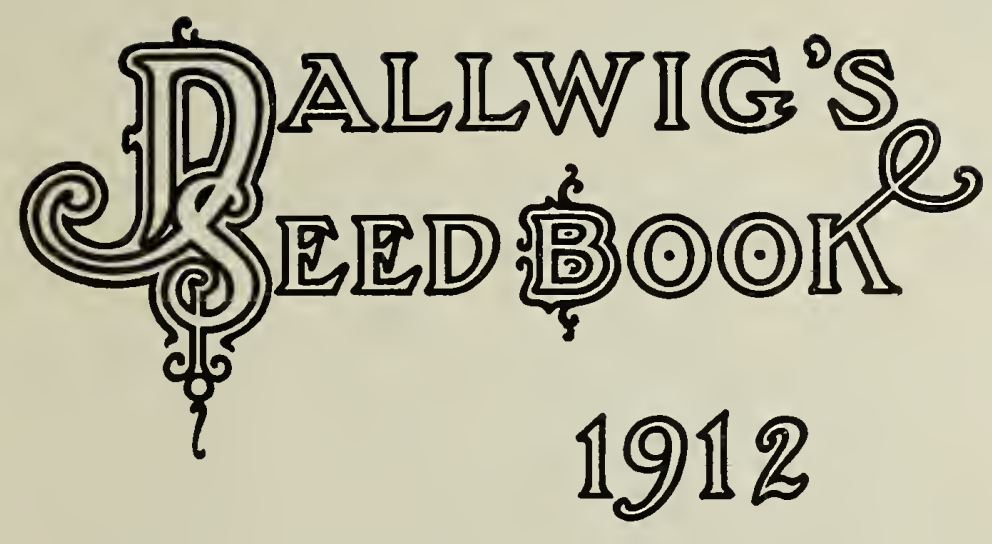

THIS book has been carefully revised with a view of presenting to the garden-maker a list of varieties in choosing from which he cannot go wrong. It does not offer sorts of years ago, if newer and better types have since been produced. It contains ready reference planting tables, and many useful and time-saving classified lists. Being based on a lifelong experience in horticultural lines, and careful observation, the information it contains is accurate and reliable. To those who love the great outdoors, and who believe with us, that the pleasantest days of our lives are those we spend close to nature, this book is dedicated in the firm belief that it will prove helpful and profitable.

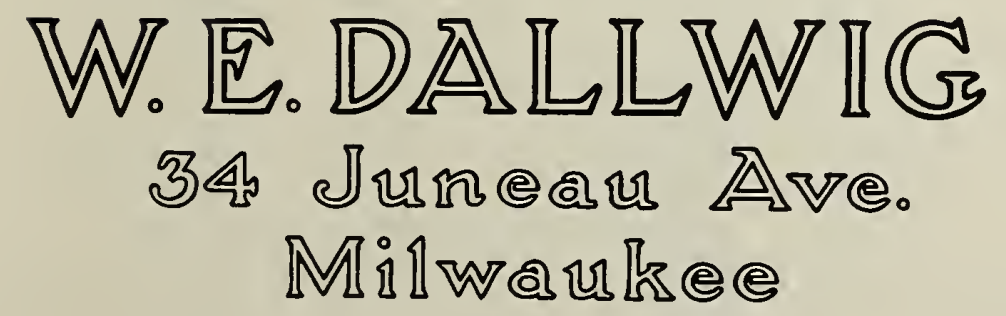




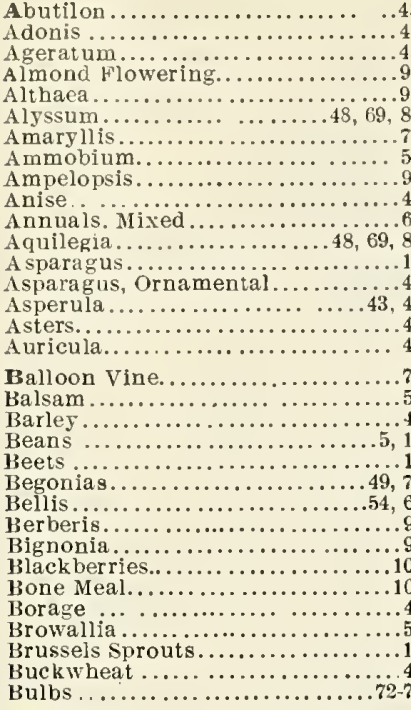

Cabbage ............... 5, 6, 17, 18,19

Caladium ............... $5,6,17,18,19$

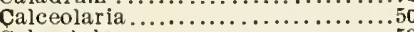

Calendula $\ldots \ldots \ldots \ldots \ldots \ldots \ldots \ldots \ldots \ldots$

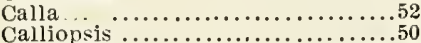

Campanula $\ldots \ldots \ldots \ldots \ldots \ldots \ldots \ldots \ldots, 6 \ldots \ldots, 82$

Canary-bird Flower..............

Canes, Bamboo.................... 107

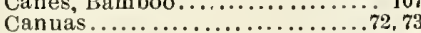

Canterbury Bell..................... $69,82,73$

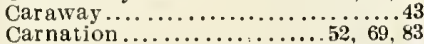

Carnation ................

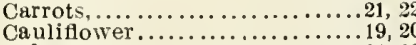

Celery $\ldots \ldots \ldots \ldots \ldots \ldots \ldots \ldots \ldots \ldots, 7,21,22$

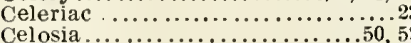

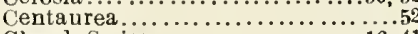

Chard, swiss....................... 41

Chervil..........................43

Chionanthus .........................

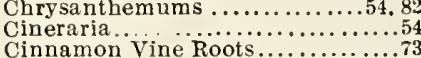

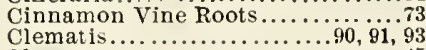

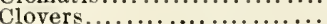

Cobaea ................................

Cocksenmb.............................

Columbine...................... $48,69.81$

Coreopsis................ $50,69,82$

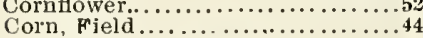

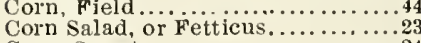

Corn. Sweet....................24

Cornus............................. ${ }^{96}, 54$

Cress

Cucumber.

Cultivators

Currants...

Cyclamen

Cyperus

Cypress vine.

Dahlia.

Dandelion

Delphinium.

Deutzia.

Dianthus.

Dibbles.

Dimorphotheca ...................

Dolichos.

Duster, Little Giant..................

Eggplant....................26

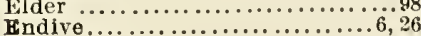

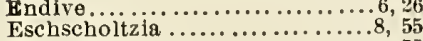

Everlastings....................... 55

Farm Seeds..................44, 45

Fennel........................
Fertilizers....................106

Flower Sceds, Culture of ..............46 Flow er Seeds. General List of ...48-71 Flower Seeds, 'Tables............47 Flower Pots ......................

furget-me-not....................56, 86

Forsythia.

Four o'clock.

Foxglore .........................

Fringe....................... 96

Fruits, small...................... 101

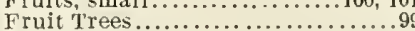

Gaillardia ................56, 69, 83

Gladiolus........................

Glazing points.......................

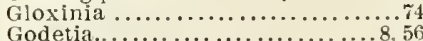

Gomphrena... .................. 55

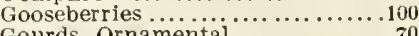

Gourds, Ornamental.............70

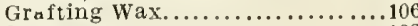

Grapes........................ 100

Grass Seed mixtures..................

Gypsophila...................... 69,89

Hardy Perennial Plants . . . . . . .80-89

Helianthus .................... 58,8

Helichrysum.................

Heliotropium

Herbs.

Herbs.............................

Hibiscus .................58, 69, 84

Holly hock................ $57,58,69,84$

Honeysuckle.................93, 97

Hotbeds.

Humulus............................

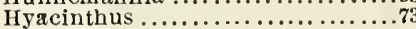

Hydrangea ..................99

Iberis...................50,51, 84

Ice Plant.................................

implements..............................

Insecticides ....................... 100

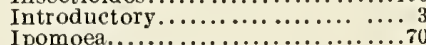

I pomoea......

Japanese:Morning-glory......... . . 1

Japan Quince...................96

Kal

Kochia

$\ldots 28$

Kohlrabi.......................,

Knives....................... 106

Labels.........................106

Larkspur...................

Lawn grass Seed................. 4

Lawn Rollers..........................

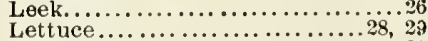

Lilac

Lilies..................................

Lily of the, Valley ...................

Linum.................... 58

Lophospermum.....................

Lophospermum...........................

Love-in a-mist $\ldots \ldots \ldots \ldots \ldots \ldots \ldots \ldots \ldots \ldots \ldots, 5$

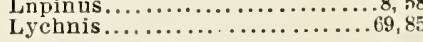

Madeira Vine................... 5

Mangel-Wurzels ................ 15

Marigold..........................

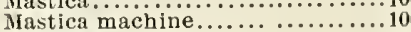

Matricaria ...................... 56

Matrimony Vine............... . 9

Maurandla....................

Mesembryanthemum Ice Plänt........

Mesembryanthemum Ice Plant..... ns

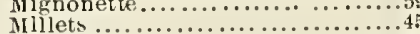

Mimosa............................

Mimulus ..........................

Mina Lobata...................

Mock Orange...................

Momordlea....................

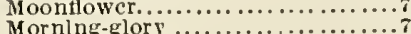

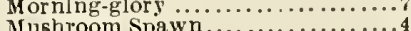

.

Musk Melon .............

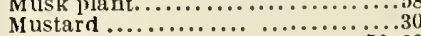

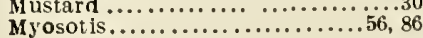

Nasturtiums.................60

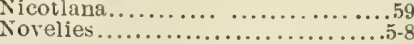

Oats......................... 45

Okra...............................

Ornamental Trees...........

Pansy .......................61

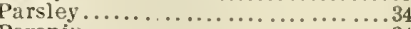

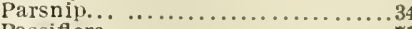

Passiflora.......................

Peanut ................................

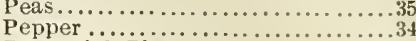

Perennial, Plants .................. 80-89

Perennials, Seeds of................ 69

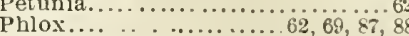

Philadelphus.....................

Pinks......................... 55

Planet Jr. implements $\ldots$

Plant Stakes.................... 10

Poppy ..................... 63, 69, 88

Portulaca .......................6 63

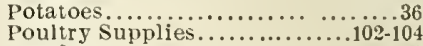

Powder gun....................... 10

Primrose....................64

Pruners, Tree...................107

Prunus ......................97

pyrethrum........................

radish .................. $37-40$

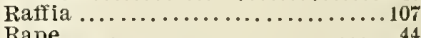

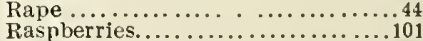

Raspberries.............................

Ricinus..................... 64

Roses .......................929 9

Rudbeckia ....................... 88

Rutabaga..........................40

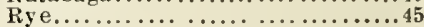

Salpiglossis.................. 65

Salsify or Vegetable Oyster........ 40

Salvia.................... 8, 65, 89

Scabiosa .........................65, 69. 88

Scorzonera...................... 40

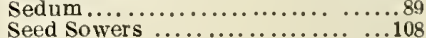

Shears............................

Shrubs.....................95-98

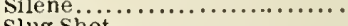

Slug Shot ........................

Smllax...

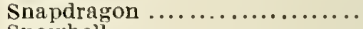

Snowball $\ldots \ldots \ldots \ldots \ldots \ldots \ldots \ldots \ldots \ldots$
snow berry $\ldots \ldots \ldots \ldots$

Snow berry.................... 98

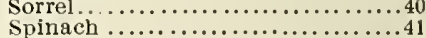

Spirea..........................98

Spray pumps and sprayers.......10

Squash .........................41

Stocks

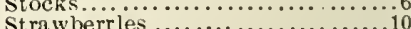

Surar Peets .

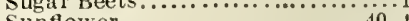

Sunflower........................

Sweet Sultan .....................

Sweet Sultan..................
Sweet William .............

Thermometers...............104, 10 \%

'Tobacco seed .......................t

Tomato .......................

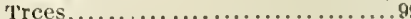

Trowels................................

Tuberose..........................

'lurnip.........................4

Vegeta ble Seeds.............. 13-4

Vegetables, Culture of ...............

Vegetables seed tables............. 10-12

Verbena.....................68 68

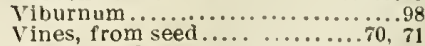

Vincs, liardy .....................90-93

violets.......................68 68

wallflower......................68

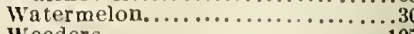

Weeders........................ 107

Welgelia ......................98

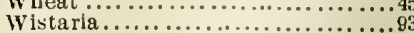

Yucca......................... 89

Zea.........................68

Zinnia............................. 


\section{Announcement}

IN PRESENTING this our annual Catalog, we desire to thank our many friends and patrons for the generous support and encouragement that has been given us in the past. Great advances have been made in Horticulture in recent years, and it has been our constant endea vor to keep pace with these, and to procure, as soon as introduced, every novelty at home and abroad that promises to be worthy of cultivation. We have purposely omitted from this catalog many varieties which have been either found inferior, or have been superseded by improved strains or varieties. Our descriptions and illustrations are conservative-nothing exaggerated. Many of our illustrations are direct from photographs of the grown product.

\section{SEED BUYING}

comes but once a year for most home gardens and should not be decided on the mere claim of cheapness, for the matter of saving a few cents is but a trifle as compared to the loss of labor, ground, and perhaps the entire crop, with much disappointment added, when seeds are bought for low prices rather than on merit.

We handle absolutely nothing which we do not believe to be the best obtainable, and we know that we have unsurpassed advantages for the procurement of the best seeds at a cost which will enable us to offer them to our customers at the lowest prices at which well-grown and selected seeds true to name can be furnished; but we do not claim to compete in prices with those made by irresponsible and haphazard growers and dealers whose sole effort is to secure the lowest priced seeds regardless of quality; such seeds are not cheap, but dear at any price.

We take all possible care to supply only such stock as will, under proper conditions, produce satisfactory results. Still seeds of the best quality will sometimes fail, due to causes entirely beyond our control, such as: sowing too deep or too shallow, in too wet or too dry soil; insects of all descriptions destroying the plants as soon as, or before, they apwear above the ground; cold or dry air may check the growth of young plants or destroy them entirely, and a great many other contingencies may arise to prevent the best seeds from giving satisfaction. For all these reasons it is impossible to guarantee seeds, and we must therefore disclaim all responsibility as to results obtained from any seeds, bulbs, or plants we send out.

WE GIVE NO WARRANTY, EXPRESS OR IMPLIED, AS TO DESCRIPTION, OUALITY, PRODUCTIVENESS, OR ANY OTHER MATTER OF AMY SEEDS, BULBS OR PLANTB WE SEND OUT, AND WE WILL NOT BE IN ANY WAY RESPONSIBLE FOR THE CROP. IF THE PURCHASER DOES NOT ACCEPT THE GOODS ON THESE TERMS, THEY ARE AT ONCE TO BE RETURMED.

\section{General Directions to Correspondents}

Our Terms are strictly Cash with the order. Our goods being of First Quality, and very low in price, we must request our customers to ask no indulgence from us in the way of time.

How to Send Money. Money Order. The rates charged for money orders are now so low that Shis is the best way to remit. They are CHE $\mathrm{P}$ and ABSOLUTELY SAFE. Postage stamps in small amounts are taken as cash, but they must be sent so they will not stick together. If personal checks are sent, the cost of exchange should be added. Letters containing cash should always be registered

Free Delivery. The deliver free to any post-offce in the United states all fower and vegetable Free Delivery. seeds by the packet or ounce. 8 cents per pound should be added for larger quantities, if wanted by mail. If beans, corn and peas are wanted by the pint or quart please add to remittance at the rate of 8 cents per pint and 15 cents per quart. Plants, shrubs, fertilizers, insecticides and sundries are at all times excluded from free delivery.

Packing. No charge is made bor boxes or packing, nor for delivery to Freight Depots or Express Offices in Milwaukee. We charge only for two-bushel cotton bags at 20 cents each.

Name and Address. COUNTY and STATE; also give street number and P. O. Box if any; alCOUNTY and STATE; also give stree
so NEAREST EXPRESS OFFICE. We try to ship all orders the same or the next day after receipt, but during
Prompt Delivery. the busy season slight delays may sometimes occur; for this we ask the indulgence of our customers.

$\overline{\text { Market Gardeners }}$

and Truckers, Public Institutions and others who need seeds in larger quantities, will on application, be supplied with a:Special Price List. 


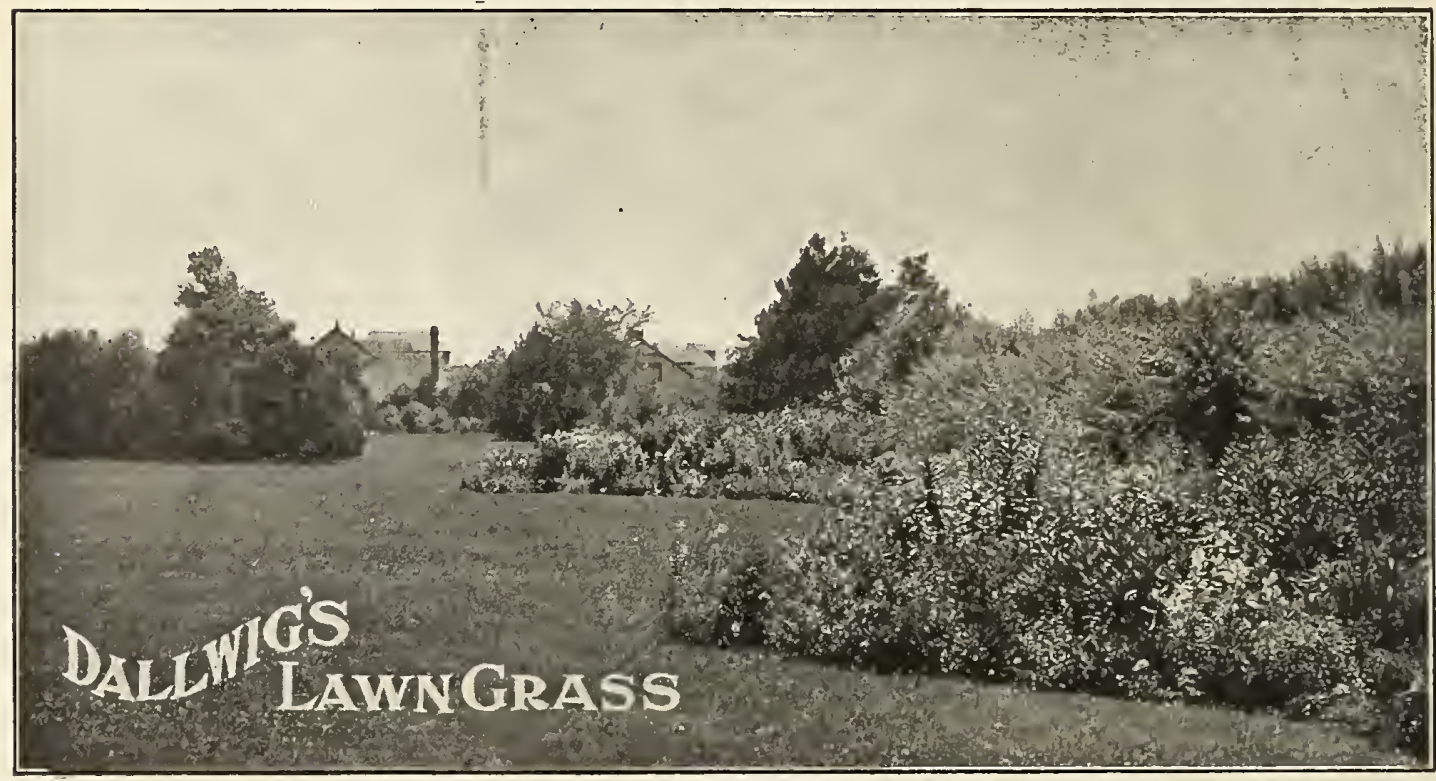

There is nothing which adds more to the external attractiveness of a home than a beautiful lawn. Anyone can have it. It will grow in the back yard of a city house as well as in the front. It will grow in the village as well as in the meadow or on the hillside. It is the world-wide covering of the earth as beautiful as flowers, more durable, less costly, nature's own blanket over the rocky soil. Little trouble to prepare the soil to receive the seed, always a fair certainty of its growing, and when established a thing of beauty and a joy.

There exists no reason for unsightly or bare spots in yard or lawn, no reason except indifference to the beautiful. Put down grass seed wherever it is wanted and you will be amply repaid in the satisfaction of having beautified your grounds.

The Lawn Grass Mixture which we offer should not be compared with the cheaper preparations advertised. Our prescription is of the best chosen varieties as respects color, texture and permanency, and will in the shortest time possible produce a beautiful, dwarf, compact turf, which will endure the summer heat, and insure a rich, deep green sward throughout the season. In making up this mixture, we are extremely careful to use only the very best quality seed, which has been thoroughly recleaned, the light seeds and chaff being removed, and only clean, heavy, pure seeds retained. Much low priced grass seed is always offered, but close examination will generally reveal the fact that this consists largely of chaff, or of the coarse growing, cheap varieties of grasses which are not adapted for fine lawns. Anyone who purchases cheap, badly mixed Lawn Grass will soon realize that it was a poor investment, as the error will stand out for years is glaring ugliness.

1 pound for 400 square feet of lawn, $\$ .30$

5 pounds for 2000 square feet of lawn, 1.35

10 pounds for 4000 square feet of lawn, 2.60

25 pounds for one-fourth acre of lawn, $\$ 6.25$ 50 pounds for one-half acre of lawn, $\quad 12.00$ 100 pounds for one acre of lawn,

23.00

For renovating old lawns use about half of above quantities.

MIXTURE FOR SHADED PLACES. This mixture is especially prepared for use in shaded places, under trees, etc. 1 pound $35 \mathrm{c}, 5$ pounds $\$ 1.50,10$ pounds $\$ 2.75,25$ pounds $\$ 6.50,50$ pounds $\$ 12.50$. MIXTURE FOR TERRACES AND EMBANKMENTS. Prices same as for Shade Grass.

WHITE CLOVER. Best grade, per pound 50c.

LAWNS and how to make them. A booklet which tells how to make and care for a lawn,preparing the soil, fertilizing, seeding, mowing, watering, rolling, - free on request.

\section{FERTILIZERS FOR LAWNS}

Lawn grass is a heavy feeder and will not thrive and hold its beautiful dark green color and velvety appearance unless it receives a sufficient supply of suitable food. Because few appreciate this fact is the reason there are so many poor, rusty lawns. Stable manure is unpleasant to handle, ill-looking and full of waste material. It contains weed seeds, and it often takes years to eradicate the weeds, causing an unnecessary amount of labor. All these objections are obviated by the use of Pure Bone Meal and Pulverized Sheep Manure. These will be found listed under Sundries. 


\title{
NOVELTIES AND SPECIALTIES
}

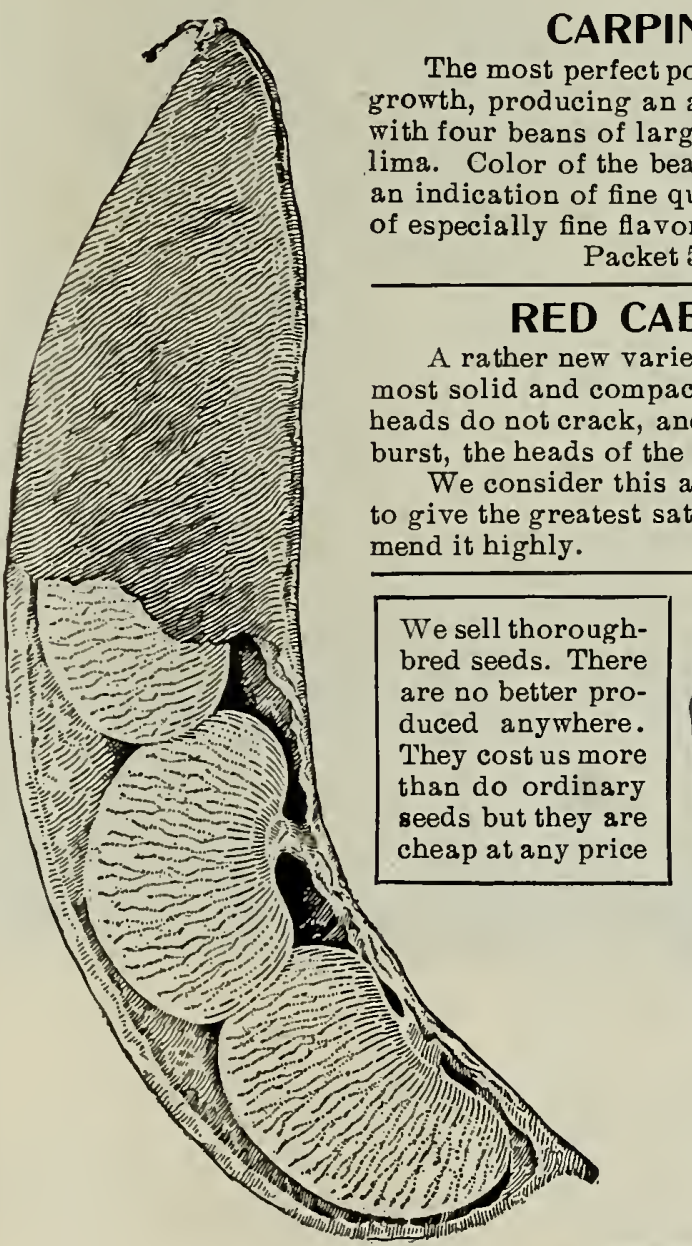

\begin{abstract}
The most perfect pole lima yet introduced. Vine strong, of vigorous 列 s largest size, and much thicker than the average pole bean is distinctive in having a decided greenish tint, an indication of fine quality. Are very thin skinned, extremely tender and

Packet 5c, pint $10 \mathrm{c}$, pint $20 \mathrm{c}$, quart $35 \mathrm{c}$, postage extra.
\end{abstract}

\section{RED CABBAGE, "Danish Stonehead"}

ther new variety, put on the market only recently. It is the largest pact of all red varieties, sure heading and tender. The heads do not crack, and even in late spring, when all other varieties have urst, the heads of the "Danish Stonehead" remain hard and. sound.

We consider this a great improvement upon all existing sorts, bound to give the greatest satisfaction in every case, and therefore we recommend it highly.

Packet 10c, ounce $45 \mathrm{c}$, t pound $\$ 1.40$

\section{CARPINTERIA POLE LIMA \\ CUCUMBER \\ DAVIS PERFECT}

\section{Nothlng Better for Slicing}

The most popular cucumber of the extra long white spine type It combines the most desirable features,-length, slimness and
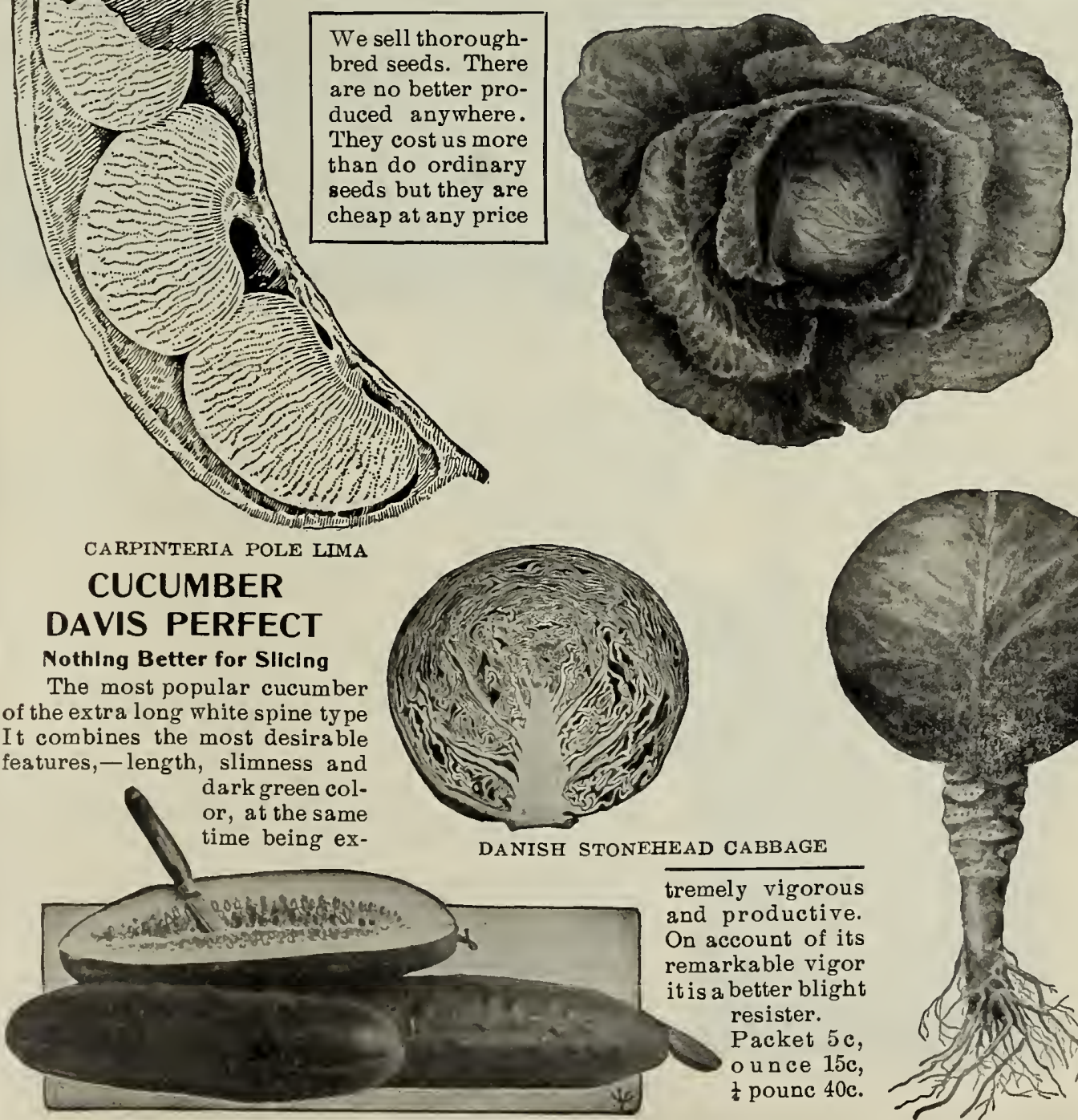

DAVIS PERFECT CUCOMBER 


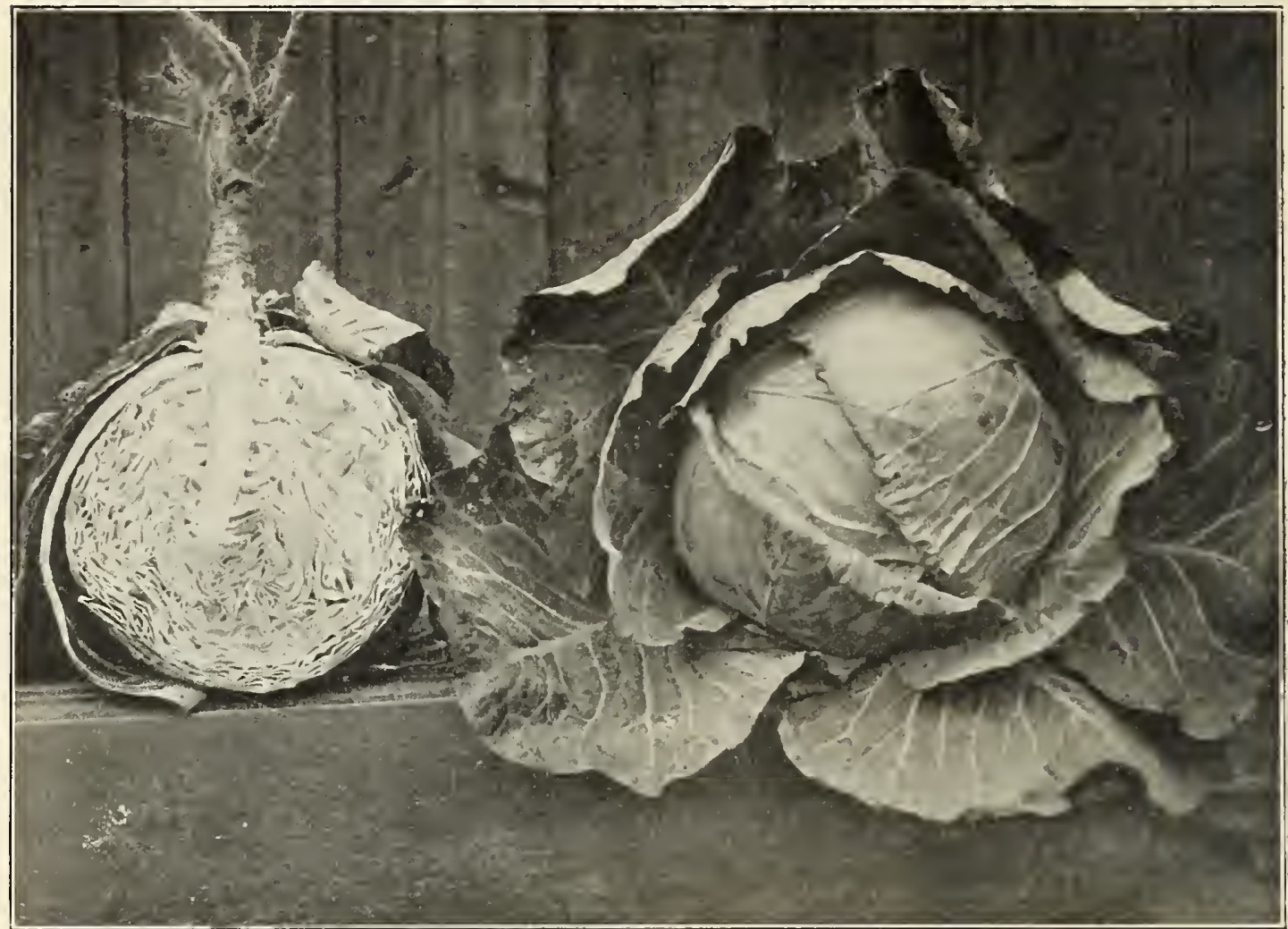

EARLIEST DANISH SUMMER BALLHEAD CABBAGE

\section{CABBAGE, EARLIEST DANISH SUMMER BALLHEAD}

This is an entirely new cabbage, now offered for the first time. It is without a rival as the finest large, round headed, early cabbage, and will prove a most attractive sort, especially for market purposes. It is extremely early-as early as Charleston $\mathrm{W}$ akefield-but, notwithstanding this, the heads are large and solid, and of very fine texture. They are ball-shaped, with but few outside

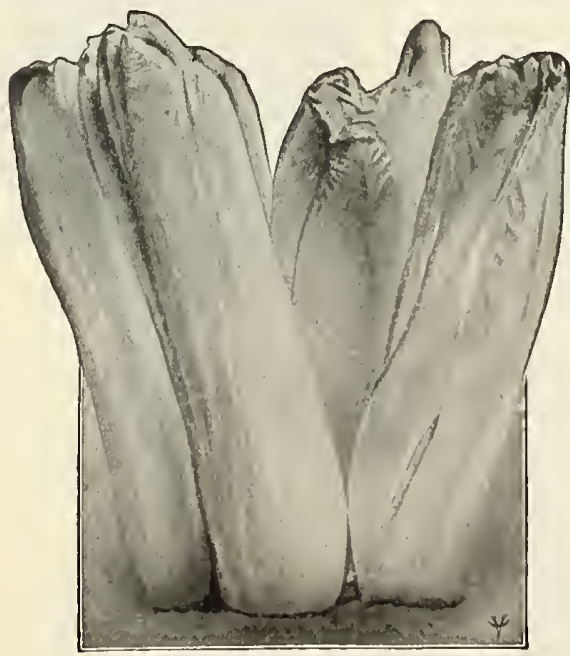

WITLOOF CHICORY leaves. The stem is of medium height.

We believe this new cabbage will soon become as prominent among the early varieties as the "Hollander" ranks high among the later sorts.

Packet $10 \mathrm{c}$, ounce $40 \mathrm{c}$, $\frac{1}{+}$ pound $\$ 1.50$

\section{Witloof Chicory or French Endive A MOST DELICIOUS WINTER SALAD}

A few years ago this salad vegetable was almost unknown in America. It is now on the bill of fare of all first class restaurants. Although mostly imported as yet, it is an easily grown winter vegetable which can be raised in every home.

Without doubt, Witloof Chicory is the finest vegetable for salads grown. It comes on for use at a season to be appreciated, for it furnishes a delicious salad in winter when other fresh vegetables are not readily available.

Full directions for planting and care with each packet. Packet 5c, ounce 20c, t pound 50c

COLUMBIA CELERY. An early maturing sort unof the rich yellow tint of Golden Self Blanching. surpassed in shape and quality. The color has in it much Packet 5c, ounce 35c 
WINTER RELIANCE CELERY. This very desirable variety is considered the most attractive in color and the best in quality of any of the late keeping sorts. The plant is compact, dwarf growing, with solid heart and habit of growth very well adapted for late keeping. When ready for the late market the color is a light creamy yellow, very handsome. Its quality is unsurpassed by that of any variety of its class and is decidedly superior to most of the older long keeping sorts.

\section{The "Hoodoo"}

\section{Musk Melon}

The Hoodoo is the ideal basket and crate melon; the fruits average $1 \frac{1}{3}$ pounds, are thickly netted, as hard as a bullet, of very handsome a ppearance. Flesh very thick, of fine firm texture, rich orange color and sweetest flavor.

Packet 5c, ounce 20c, $\frac{1}{4}$ pound $50 \mathrm{c}$

\section{Musk Melon Milwaukee Market}

Originated as a cross between the old Surprise and a Gem melon. Our strain of it has been improved by careful selection, and we think for a fine home melon and a market-wagon variety it has no superior. The melon is a light green in color, nearly round with only slight sutures, flesh salmon color, wonderfully sweet, with almost no stringiness As a home garden melon we consider this variety ideal.

Pkt. 5c, ounce 15c, $\frac{1}{6}$ pound 50c

\section{Northern Adirondack EARLIANA TOMATO}

Selected for earliness, large size, thick, blocky shape, prolificness, smoothness and color.

In selecting, all fruit not showing very solid meat and small seed cavities was rejected.

Being grown in the far north, near the Canadian line, the short, cool seasons tend to breed in earliness and vigor.

Packet 10c, ounce 50c, $\frac{1}{4}$ pound $\$ 1.75$

Early Detroit Tomato. The largest and best in shape of the early purplish pink tomatoes. Vine vigorous and very productive. Fruit exceptionally uniform in size, nearly globe shaped heavy, firm, smooth and well adapted for shipping.
Packet 5c, ounce 30c

One of the largest of onions. It is a very handsome, oval shaped variety with pale straw-colored skin. For exhibition purposes it is unexcelled. To attain its largest size, it should be sown early in hotbeds, and later transplanted. Very productive, a good keeper, of mild acceptably pungent flavor.

Packet 5c, ounce 35c, $\frac{1}{4}$ pound $\$ 1.25$

\section{ONION SEED}

No vegetable is harder to keep true than the Onion. Not only are there the ordinary dangers from crossing, but if all conditions are not ideal, scallions or plants without true bulbs are very likely to be formed. Moreover, good color and shape are never attained without many seasons of the most painstaking selection; otherwise the shade in the case of reds and yellows is weak and pale, making the Onions much less attractive in the market. Our growers have been breeding onions for half a century and the results are all that the most exacting expert could desire. Our supply is produced from bulbs carefully selected from stocks representing the offspring of numberless generations each the best of its time and kind. In uniformity and excellence of color and shape, and in evenness of maturing there are few Onions in the world equal to those grown from our seed. There is none better.

\section{THOROUGHBRED SEEDS}

We sell thoroughbred seeds. There are no better produced anywhere in the world. They cost us much more than ordinary seeds but are cheap at any price. Does it not seem to you good policy to plant only thoroughbred seeds from the most successful and most extensive plant breeders in the world? 


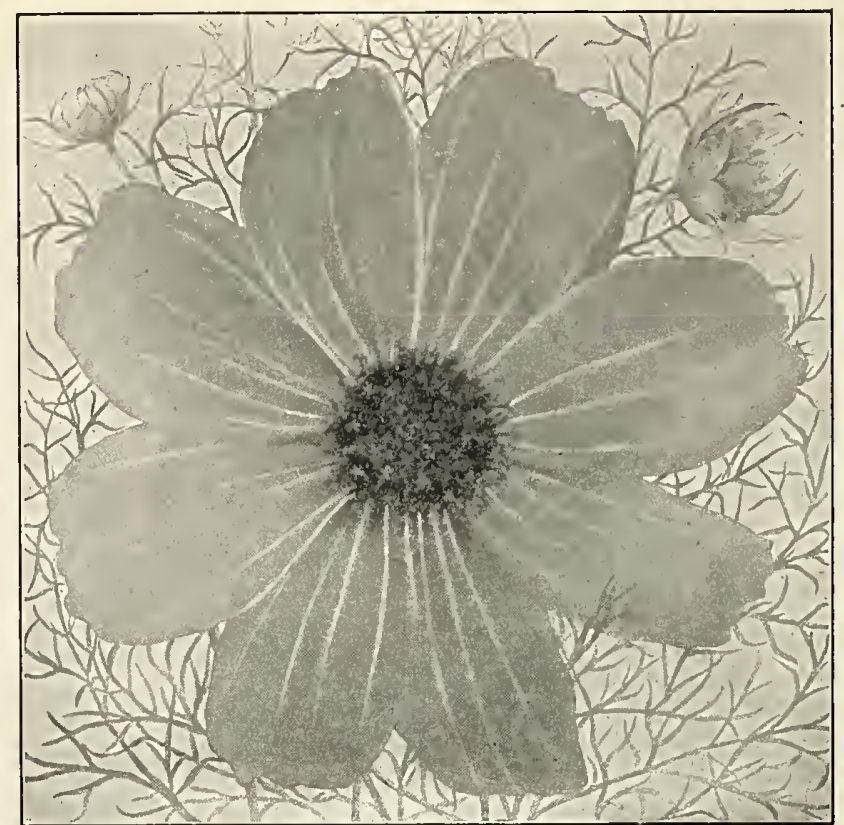

COSMOS, LADY LENOX
COSMOS, LADY LENOX GIGANTIC ORCHID.FLOWERING

An orchid-flowering Cosmos having gigantic blooms of delightful shell-pink color. A strong and vigorous grower, attaining a height of 6 to 7 feet; the flowers may be cut with any length stem up to 5 feet.

Packet $10 \mathrm{c}$

\section{Godetia, "Crimson Glow"}

This splendid new Godetia forms a compact little bush about 9 inches in height completely smothered with fowers of the most dazzling intense crimson. A bed of this variety produces a vivid effect the intensity of which it is impossible to describe, and to be fully appreciated it must be seen growing.

Packet $10 \mathrm{c}$

\section{Lupin "Pink Beauty"}

Easy of culture, graceful in bearing, splendid for cutting, free in blooming, and delicate in color, this new annual is destined to become one of the most popular garden flowers.

Packet 10c

\section{Dimorphotheca Aurantiaca}

An extremely showy annual from Namaqualand, South Africa, of very easy culture. The plants are of neat branchy habit, grow about 12 to 15 inches high and are exceedingly profuse in flowering. Its Marguerite-like blossoms, $1 \frac{1}{2}$ inches in diameter, show a unique glossy rich orange-gold, with a dark-colored disc surrounded by a black zone. Well adapted for groups or borders; produces its pretty flowers very early after being planted out in sunny situations.

Packet 10c

\section{Escholtzia Thorburni}

The grandest of all Escholtzias. In habit it is the same as the California Escholtzia, commonly called California Poppy, but it is decidedly dis-

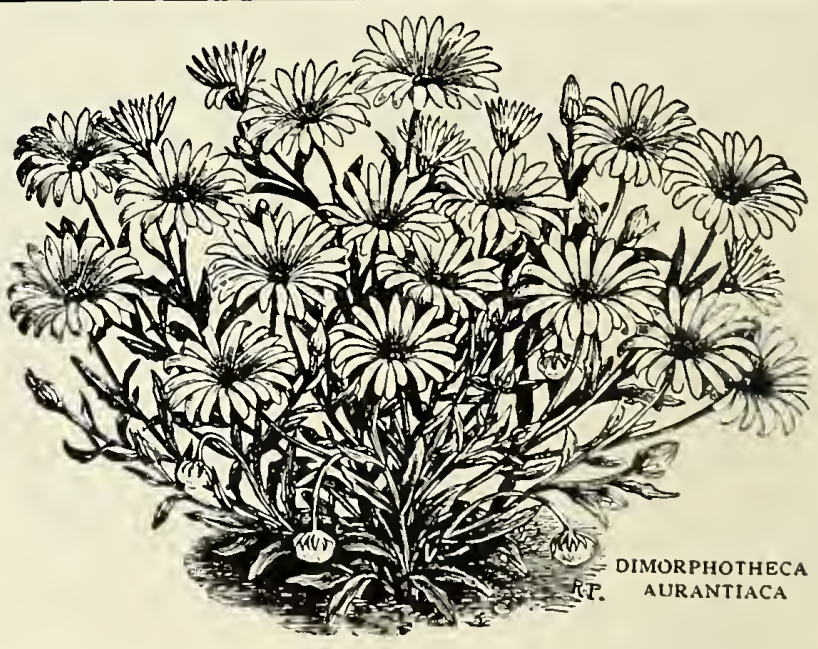
tinct in its coloring, which might almost be described as being barbaric in splendor. The unopened buds on outer side of petals are of the richest deepest possible crimson, toning down on the inner side to bright flame-color and molten-gold. The flowers are lalger than those of other Escholtzias and are borne with equal profusion. Packet 10c

\section{SWEET WILLIAM}

JOHNSON'S GIANT. An extraordinary novelty the individual flower being of the size of half-adollar. Besides this the range of colors includes shades which are not to be found in other strains and the peculiar and delicate markings on the flowers are most attractive. Packet 10c

\section{SWEET WILLIAM}

EVERBLOOMING HYBRID. This beautiful Dianthus is a cross between the China Hink and Sweet William, combining the free and continuous blooming qualities of the former with the hardiness of the latter. Color velvety crimsonscarlet. Blooms from seed first year. Pkt. 10c

SALVIA, ZURICH. One of the best introductions of recent years. Compact and rather dwarf of growth; produces flower spikes as early as July, and stays in bloom until killed by frost, increasing in brilliancy and size as its growth progresses. 


\section{Standard Vegetable Seeds For Market and Standard Vegetable Seeds Home Gardens.}

$\mathbf{A}^{\mathrm{LL}}$ cluNDARD VARIETIES OF REAL VALUE may be found in this department. We ex-

ing descriptions, and do not ofier same varieties under different names. It has ever been our endeavor as seedsmen to make Highest Quality the first consideration and then to fix our prices as low as Good, Reliable Seeds can be sold. Department and other stores sometimes offer seeds in packets at seemingly low prices. Examination will show that the packets though bright and attractive, are small, often containing less than one-fourth as much as one of ours, and trial will often demonstrate that, even if the seeds have sufficient vitality to come up, the product will be unsatisfactory. The use of poor seeds always results in disappointment and loss. The best is always the cheapest. We offer you the very best seeds which can be produced, and at the lowest prices consistent with the highest quality.

All Seeds, except where noted, 5 cents per packet; half packets at 3 cents each.

\section{GENERAL CULTURAL DIRECTIONS}

To secure a good crop of vegetables, three things at least are necessary; viz., a suitable soil, pure seed and clean culture. A rich, sandy loam is the best, but a fair degree of success may be secured from any soil which can be made rich and friable. If the soil be stiff, it should be gradually mellowed by the free use of barnyard manure, or, if convenient, by the addition of sand. If wet, or inclined to hold an excess of moisture, it should be underdrained.

Rich soil and liberal manuring will a vail little without thorough preparation. The soil must be made friable by thorough and judicious working. The ground should be frequently hoed, to kill the weeds and keep the soil mellow, and the proper time to hoe is just when the weeds appear above ground. Not only should every weed be removed as soon as it appears, but the crust which forms after a rain should be broken up and the ground stirred as soon as it is dry enough to permit it. The more frequently and deeply the soil is stirred while the plants are young, the better, but as they develop and the roots occupy the ground, cultivation should be shallower until it becomes a mere stirring of the surface.

Much time may be gained by starting certain kinds of plants in a hot-bed. The construction of these is so simple and the expense so slight that everybody should have one. We give below brief

\section{DIRECTIONS FOR MAKING A HOT.BED}

The best material that is easily available is fresh horse manure, containing a liberal quantity of straw bedding. The manure should be forked over, shaken apart, and if dry, watered and allowed to stand a few days and then be forked over again, piled and allowed to heat a second time, the object being to get the whole mass into a uniform degree of fermentation, and as soon as this is accomplished it is fit for use.

When everything is ready, the manure is placed in the pit, carefully shaking out and spreading each forkful and repeatedly treading down the manure so as to make the bed as uniform as possible in solidity, composition and moisture. Unless this is carefully done, one portion will heat quicker than the other and the soil will settle unevenly, making it impossible to raise good plants.

The manure should be packed to a depth of about two feet. Then put on the frame and sash. The heat will soon rise to 100 degrees or more, which is too hot to sow the seed; but in two or three days it will subside to 90 degrees or a little less, when the soil may be put on to the depth of 6 or 8 inches. The soil should be light and friable, and care should be taken that it is dry. Fresh manure should be carefully packed around the outside of the frame to the very top.

Air must be given every mild day by raising the sashes at the back. Water with tepid water whenever necessary, and during cold nights and snowstorms keep covered with mats or board shutters. The details of management, however, must be learned by experience, but may be easily acquired by anyone who gives the matter careful attention, keeping constantly in mind the essentials given above.

OUR SEED Please show this SEED CATALOG to your friends, and if you should receive an CATALOG. extra copy, be kind enough and hand it to some neighbor interested in seeds. We would be glad to send a copy free to any of your friends likely to want seeds. An order this season, no matter how small, secures our catalog for the next as soon as issued. 


\begin{tabular}{|c|c|c|c|c|c|c|c|c|c|c|c|c|c|c|c|}
\hline 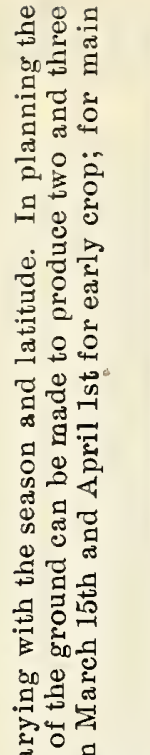 & 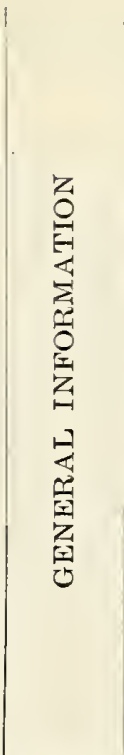 & 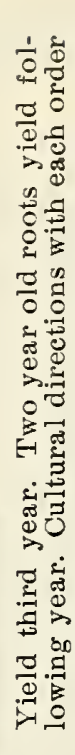 & 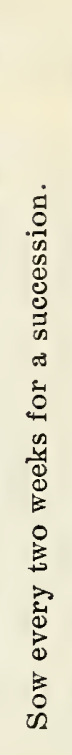 & 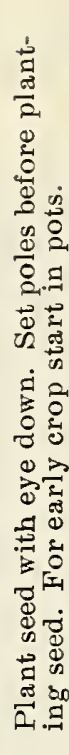 & 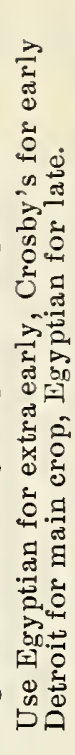 & 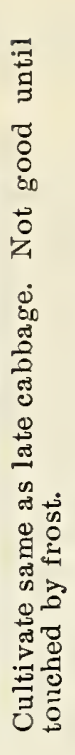 & 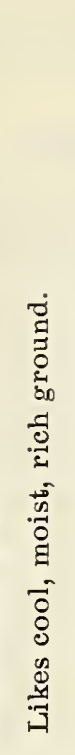 & 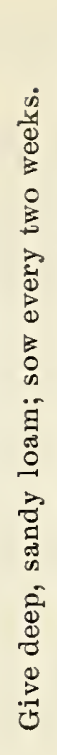 & 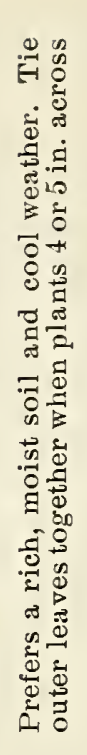 & 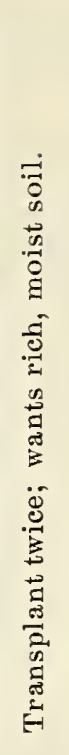 & 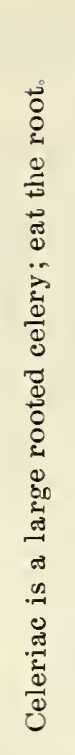 & 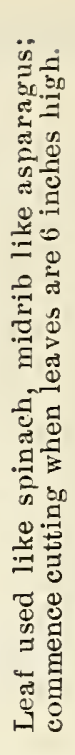 & 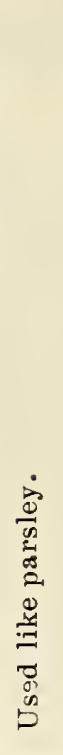 & 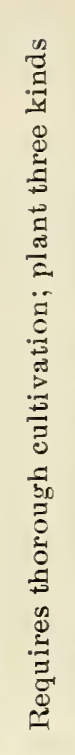 & 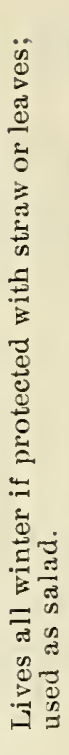 \\
\hline 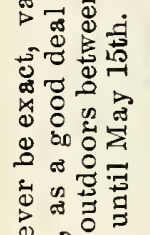 & 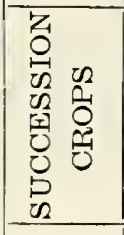 & $\begin{array}{l}\text { J } \\
\text { 之े }\end{array}$ & 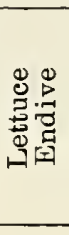 & & 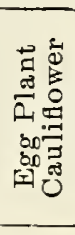 & & 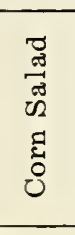 & & 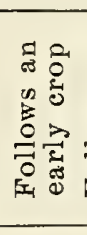 & 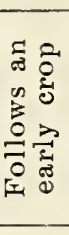 & 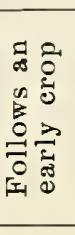 & 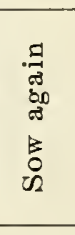 & & 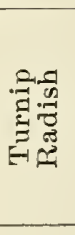 & \\
\hline 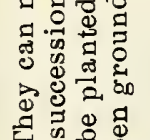 & 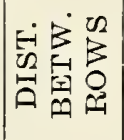 & $\stackrel{\leftrightarrow}{-}$ & $\stackrel{\infty}{\sim}$ & $\ddot{m}$ & $\stackrel{\sim}{-1}$ & స & คి & กี & คి & $\vec{N}$ & त & $\stackrel{\infty}{\sim}$ & $\stackrel{\leftrightarrow}{\sim}$ & 藏 & $\infty$ \\
\hline 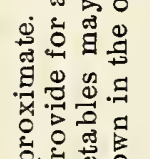 & 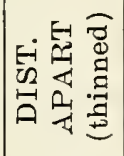 & 0 & $\begin{array}{l}0 \\
\stackrel{0}{+} \\
\qquad\end{array}$ & $\stackrel{\circ}{\circ}$ & 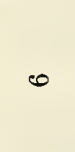 & $\stackrel{\sim}{\sim}$ & คి & $\begin{array}{l}0 \\
\vdots \\
\dot{0}\end{array}$ & $\stackrel{\infty}{\sim}$ & $\begin{array}{l}\infty \\
0 \\
0 \\
0\end{array}$ & $\begin{array}{l}\infty \\
0 \\
0 \\
0\end{array}$ & $\begin{array}{l}\stackrel{\circ}{-1} \\
\stackrel{+}{+} \\
\infty\end{array}$ & H & so & $\begin{array}{l}0 \\
\stackrel{8}{+}\end{array}$ \\
\hline 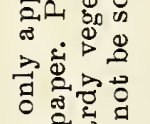 & 四息息 & A & $\begin{array}{l}A \\
\dot{0} \\
\dot{H}\end{array}$ & 田 & A & A & a & $A$ & A & $A$ & A & A & $\theta$ & 可 & A \\
\hline 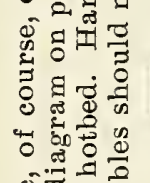 & 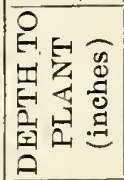 & 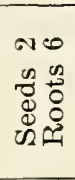 & $\sim$ & $N$ & $\underset{r}{-2}$ & $\lambda N$ & $\mathcal{L N}$ & IN & 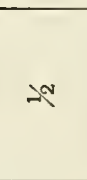 & 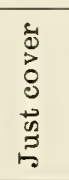 & 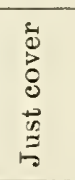 & $\underset{\sim}{2}$ & SN & $\underset{\sim}{-N}$ & $\lambda$ \\
\hline 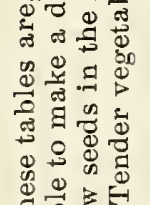 & 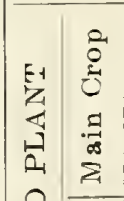 & ") & $\begin{array}{l}\dot{s 0} \\
\sum_{4}^{4} \\
0 \\
\dot{H}-1\end{array}$ & 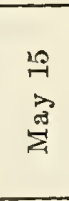 & 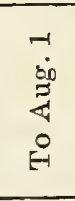 & 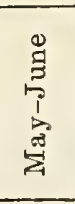 & 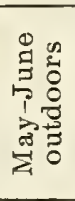 & 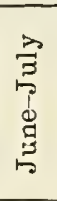 & $\overrightarrow{\vec{a}^{\circ}}$ & $\overline{\vec{c}}$ & 总 & 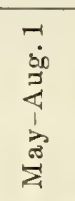 & 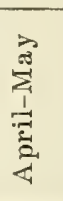 & 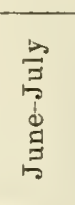 & $\frac{\overrightarrow{3}}{\frac{1}{4}}$ \\
\hline 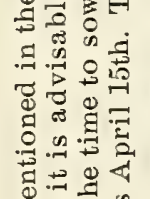 & 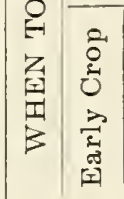 & & $\stackrel{\vec{\Phi}}{\sum^{\infty}}$ & & 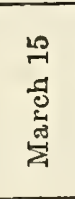 & & 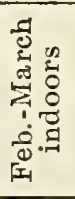 & 苟 & 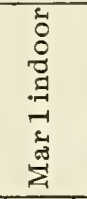 & 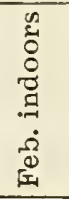 & $\begin{array}{l}0 \\
\tilde{0} \\
0 \\
0 \\
0 \\
0 \\
0 \\
0 \\
1\end{array}$ & $\overline{\frac{a}{4}}$ & & $\stackrel{\vec{\sigma}}{\overrightarrow{\mathrm{\sigma}}}$ & $\begin{array}{l}\dot{3} \\
\dot{0} \\
1 \\
1 \\
\dot{\theta 0} \\
\ddot{z}\end{array}$ \\
\hline 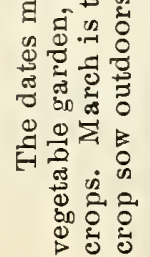 & 窒 & 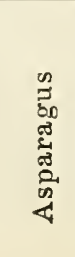 & 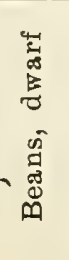 & $\begin{array}{l}\stackrel{0}{0} \\
\vdots \\
\vdots \\
0 \\
0 \\
0 \\
\infty\end{array}$ & 苋 & 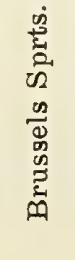 & 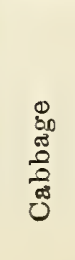 & $\begin{array}{l}\overrightarrow{0} \\
\dot{0} \\
\text { : } \\
\text { రే }\end{array}$ & 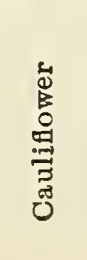 & $\begin{array}{l}\stackrel{\vec{d}}{\vec{d}} \\
\stackrel{0}{0}\end{array}$ & 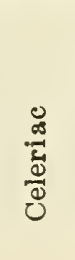 & 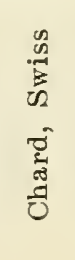 & $\begin{array}{l}\overline{\vec{D}} \\
\stackrel{d}{0} \\
\overline{0}\end{array}$ & $\begin{array}{l}\text { मี } \\
0\end{array}$ & $\begin{array}{l}\frac{\pi}{\pi} \\
\frac{\pi}{\pi} \\
0 \\
0 \\
0\end{array}$ \\
\hline
\end{tabular}




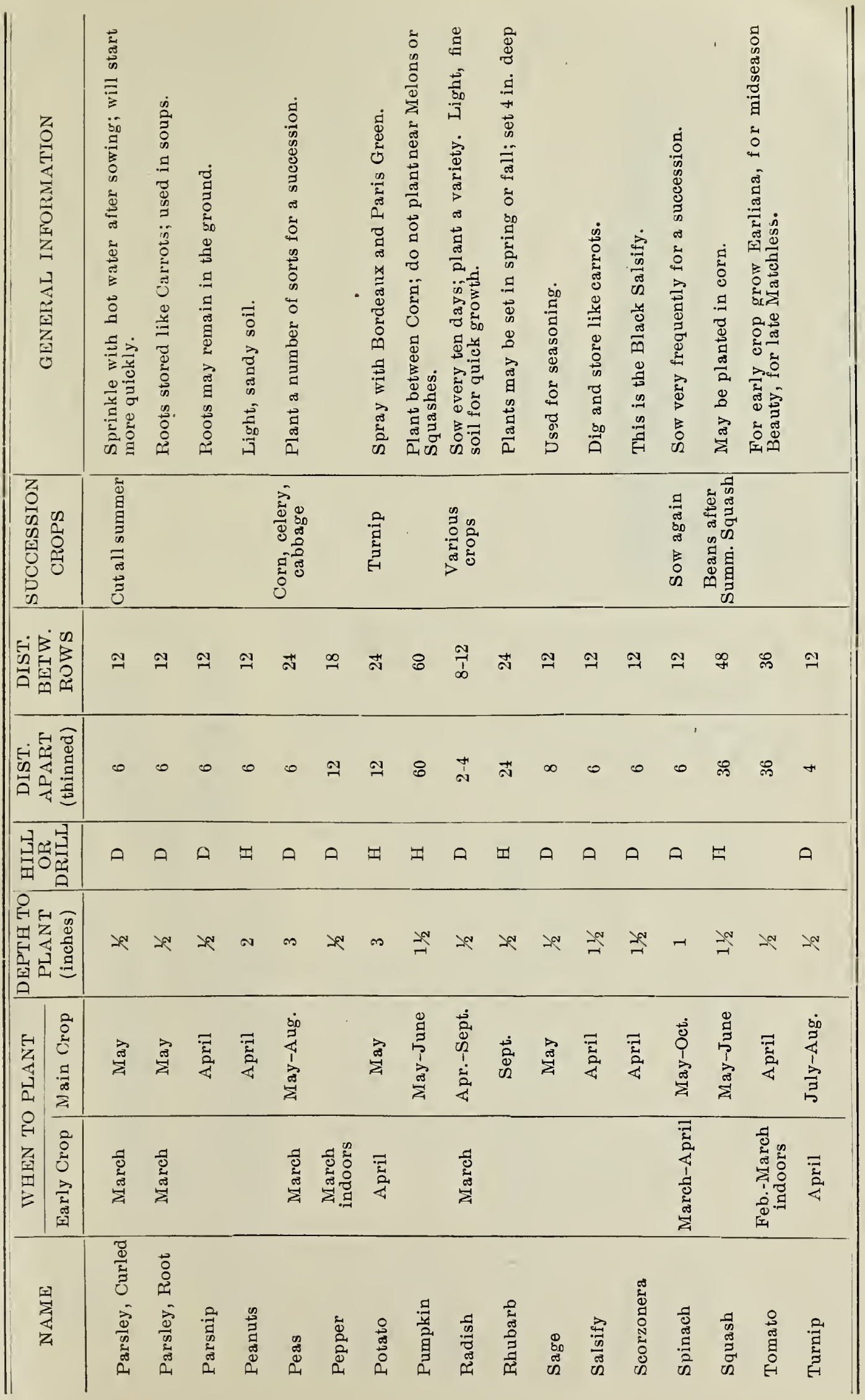




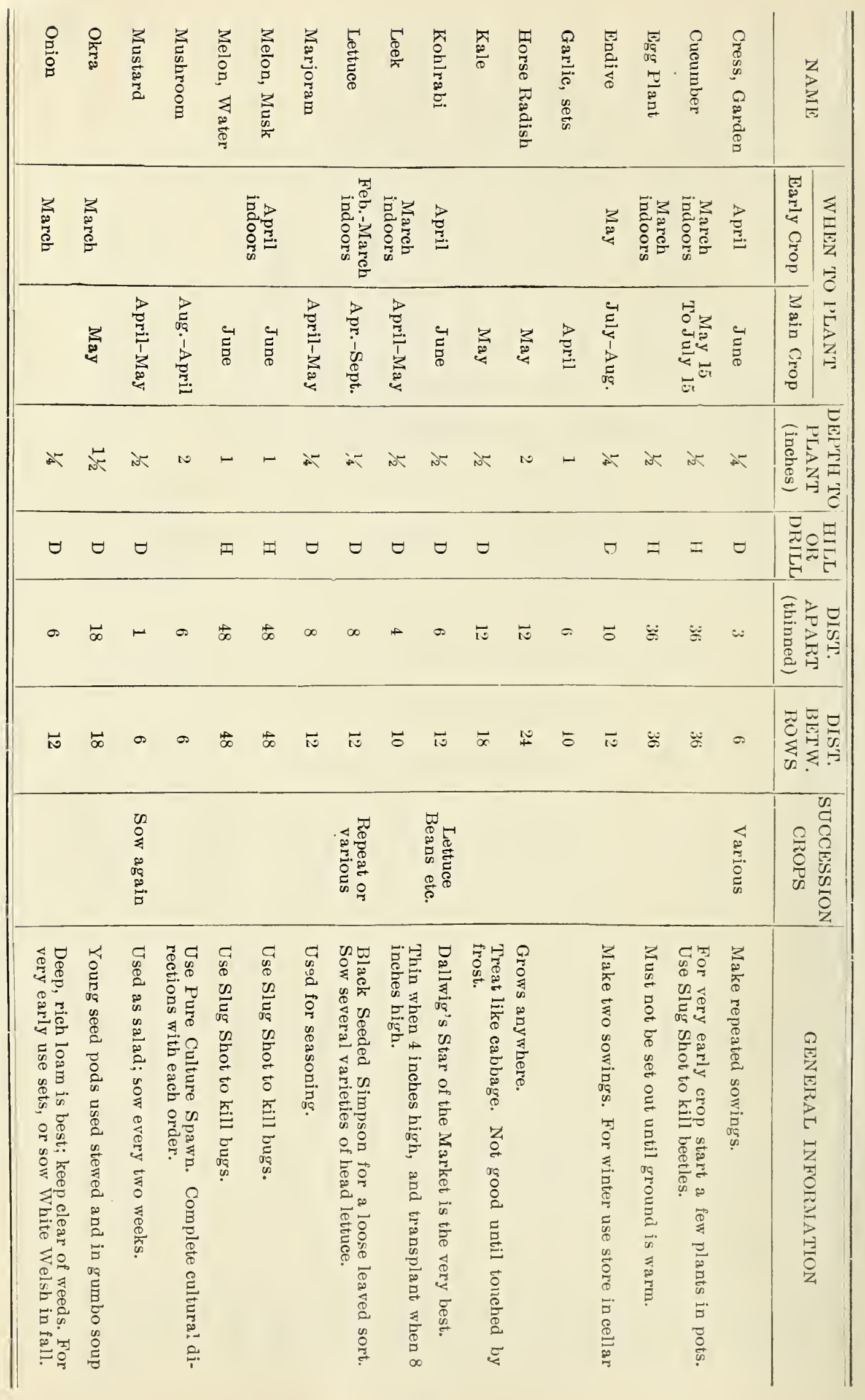




\section{ASPARAGUS SEED}

Cultural directions furnished with each order, if requested.

Columblan Mammoth White.-Shoots are white and remain so without earthing or blanching. It is strong in habit, throws very large and numerous shoots. Packet. 5c, ounce 10c, $\frac{1}{4}$ pound $20 \mathrm{c}$ Conover's Colossal.-A standard variety, of large size, tender and of excellent quality. Packet $5 \mathrm{c}$, ounce $10 \mathrm{c}$, 1 pound $20 \mathrm{c}$ ASPARAGUS ROOTS. If desired by mail, add 50c per 100 ASPARAUUS ROOTS. for postage.

Columbian Mammoth Whlte.- (2-year-old plants. Per dozen 15c, Conover's Colossal.- $\quad\}$ per $100 \$ 1.00$

\section{BEANS DWARF or BUSH}

\section{WAX PODDED VARIETIES}

WARDWELL'S KIDNEY WAX.-One of the best early wax beans. It is almost entirely free from rust. The pods are long and showy, very tender, and of excellent quality, and assume a rich golden color. DAVIS WAX. - AN EXCEEDINGLY HARDY, PRODUCTIVE, WHITE SEEDED WAX BEAN. All of the pods are very long, straight and hand-

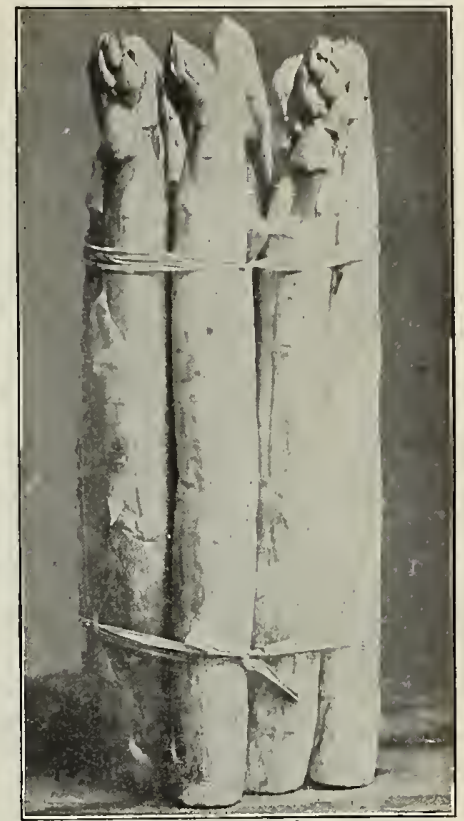

ASPARAGUS, COL. MAM. WHITE some. The vine is vigorous, bear- ASPARA
ing near the center many clusters of pods.

MICHIGAN WHITE WAX.-Briefly described, this is a white seeded Golden Wax, but in several vital features superior to that excellent variety. The vine is a little larger, more robust and vigorous; foliage a little heavier. The light golden, comparatively broad pods are produced in great abundance and are uniform in size and color.

HODSON WAX.-The plants are well loaded with long, straight, handsome pods, which somewhat resemble those of the Davis Wax, but are plumper, straighter and longer; brittle and tender.

Currle's Rust Proof.-Early and productive, of excellent quality, and entirely free from rust.

Improved Golden Wax.-Strong in growth, attractive in appearance, a very excellent and exceedingly popular variety.

PRICE OF ALL WAX BEANS:

Packet 5c, $\frac{1}{2}$ pint $10 \mathrm{c}$, pint $15 \mathrm{c}$, quart $30 \mathrm{c}$, $\frac{1}{2}$ peck $\$ 1.00$, peck $\$ 1.75$

\section{GREEN PODDED VARIETIES}

Stringless Green Pod.-Early, productive, perfectly round, fleshy, 5 to 6 inches in length, and entirely stringless.

Extra Early Refugee.-Has all the good qualities of the Late Refugee and is ready for market at least 10 days earlier.

LATE REFUGEE, OR 1000 TO 1.-The pods are round, green, wa$\mathrm{xy}$, absolutely stringless, and extra fine in flavor. The variety most largely used for pickling.

ABOVE SORTS: Pkt. 5c, pint 15c, quart 25c, $\frac{1}{2}$ peck 75c, peck $\$ 1.40$ Broad Windsor.-Pkt. 5c, pint 20c, quart 35c, $\frac{1}{2}$ peck $\$ 1.25$, peck $\$ 2.25$ FORDHOOK BUSM LIMA.-The only stiffly erect bush form of the Potato Lima. Both pods and beans are twice the size of the Dreer's Bush Lima. Packet 5c, pint 20c, quart 35c, $\frac{1}{2}$ peck $\$ 1.25$, peck $\$ 2.25$

\section{POLE BEANS}

IMPORTED GIANT SWORD.-Bears long, wide, showy green pods in large clusters.

Packet $10 \mathrm{c}$, 青pint $20 \mathrm{c}$, pint $40 \mathrm{c}$, quart $75 \mathrm{c}$

Flageoiet Wax.-Early and tender; very productive. Price as above. Kentucky Wonder.-Long fleshy pod entirely stringless; fine quality. Scarlet Runner.-Favorite both as snap bean and for its flowers.

Carpinteria Lima.-Beans much thicker than the a verage pole lima. Thin skinned, extremely tender, and of especially fine flavor.

ABOVE THREE SORTS: Packet 5c, $\frac{1}{2}$ pint 10c, pint $20 \mathrm{c}$, quart $35 \mathrm{c}$ 


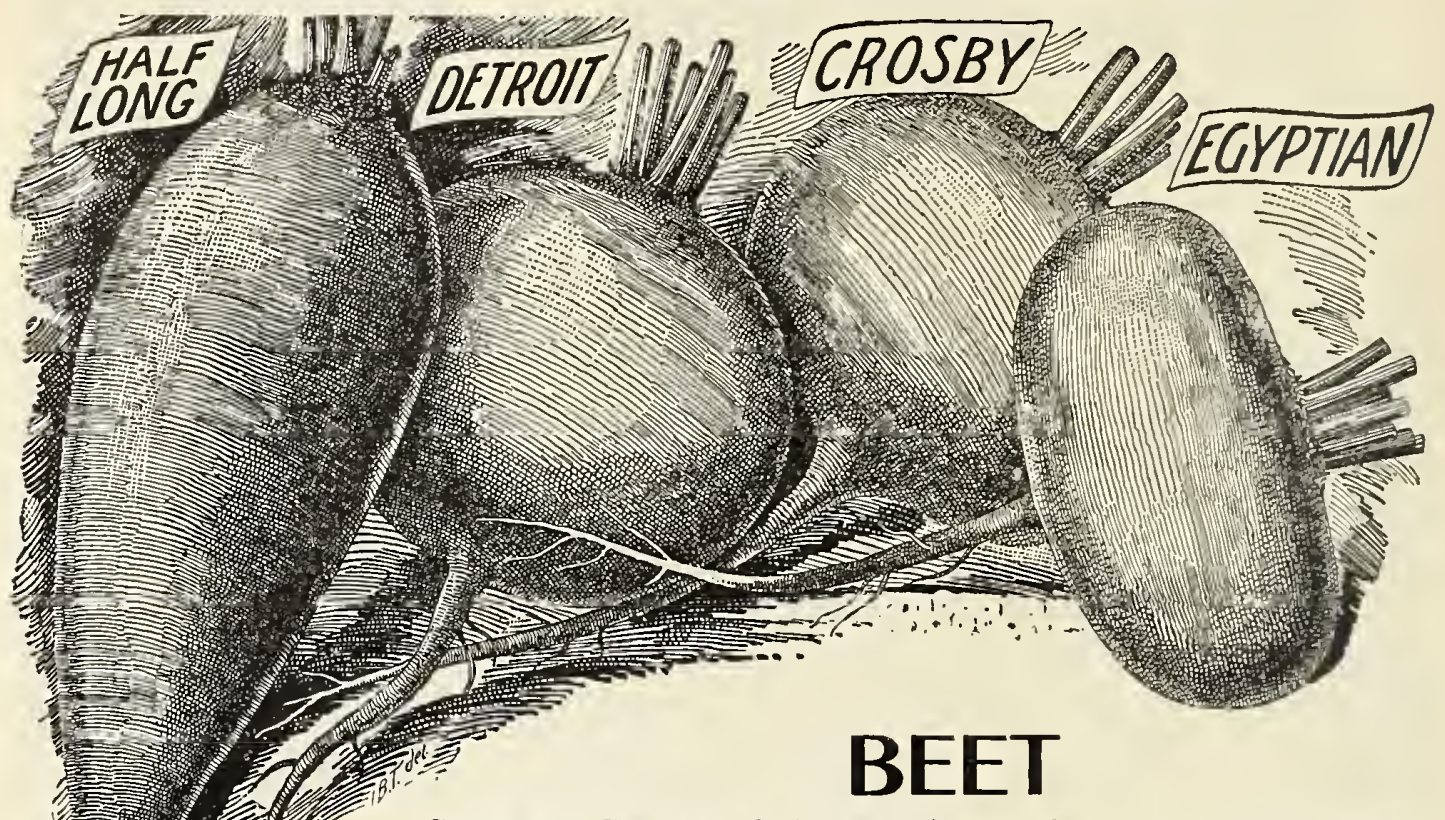

CULTURE. - Sow as early in the spring as the ground can be worked ( 5 to $61 \mathrm{bs}$. to the acre), and every two weeks after for a succession, up to the last week of July. For general crop, sow about middle of MIay. The soil should be light, sandy loam, well enriched with stable manure and plowed and harrowed until very fine. Sow in drills twelve to fifteen inches apart, and when well up thin to from four to six inches.

Extra Early Egyptian Blood Turnip. The earliest, and most excellent in quality. Deep crimson in color. The best variety for forcing, and excellent for firstearly crop out of doors, being very early, with small top. Flesh dark red, zoned with lighter shade, firm, crisp and tender. Packet 5c, ounce 15c 1/4 pound 35c, pound $\$ 1.00$ Crosby's Egyptian. A selection from that standard market beet, Extra Early Egyptian added thickness, giving it a more handsome shape. Very small tap root, deep rich color, splendid quality, and very rapid growth. Much in demand by market gardeners for forcing.

Packet 5c, ounce $15 \mathrm{c}, 1 / 4$ pound $40 \mathrm{c}$, pound $\$ 1.10$

Detroit Dark Red Turnip. Its small, upright growing tops, early maturing, and splendid Detroit Dark Red Turnip. shape and color of the roots make it popular with everyone. Leaf-stems and veins dark red, blade green; roots globular or ovoid, and vely smooth; c ol or of skin dark blood-red; flesh deep vermilion-red, zoned with a darker shade; very crisp, tender a nd sweet, and remaining so for a long time. Packet 5c, ounce 15c, $1 / 4$ pound $45 \mathrm{c}$, pound 81.50 Chicago Market. A most perfect dark blood-red kind. Even the leaves of every beet are of Chicago Market. the darkest glossy red, almost black. It is of turnip shape, first-class in size, smooth. with small tops and fine small tap root. Packet 5c, ounce $15 \mathrm{c}, 1 / 4$ pound $35 \mathrm{c}$, pound $\$ 1.00$

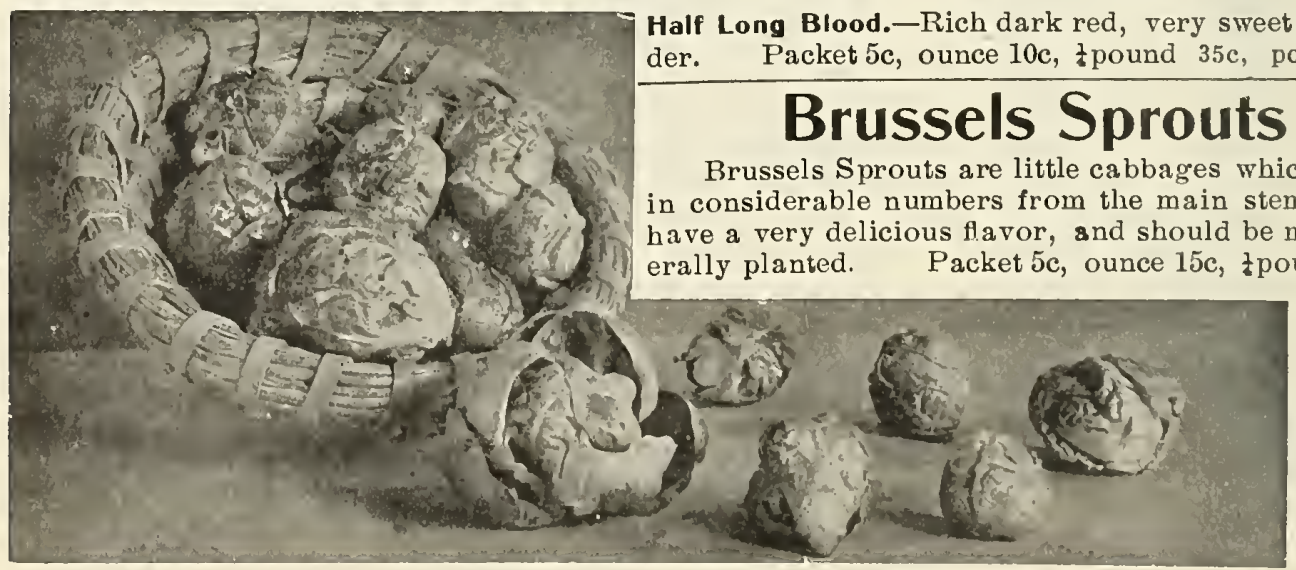




\section{SUGAR BEET. Vilmorin's Improved.-}

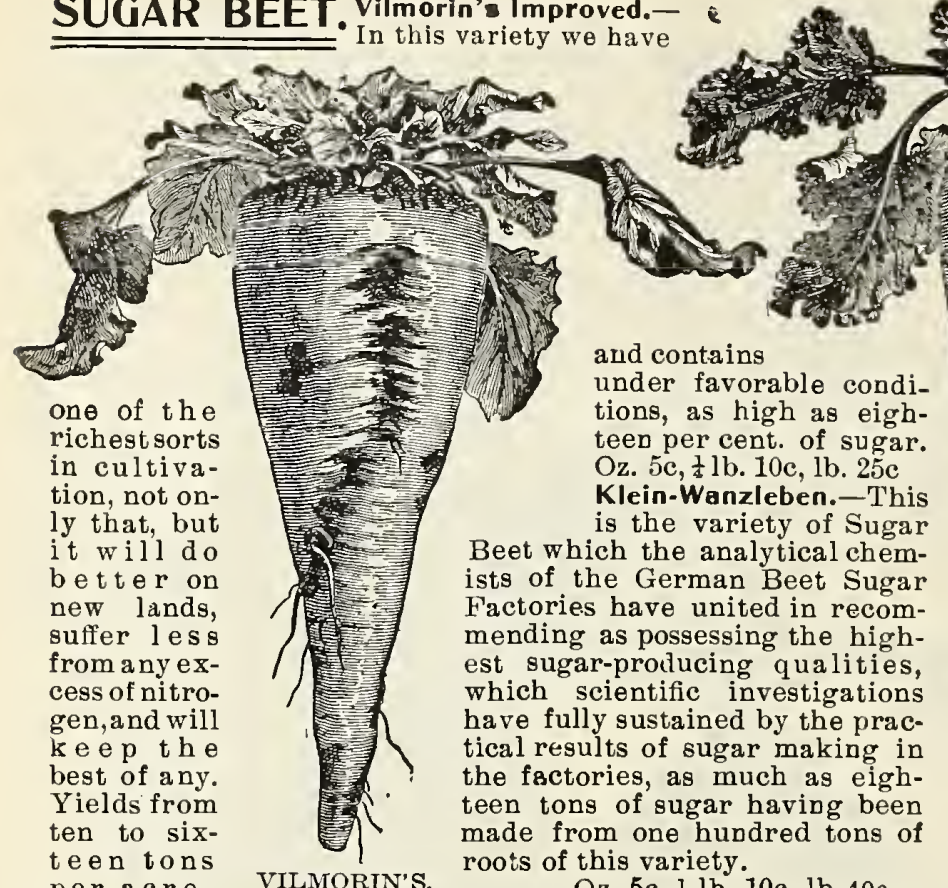

per acre, VILMORIN'S. Oz. 5c, t lb. 10c, lb.40c

\section{Glant Feeding Sugar Beet, or Half Sugar Mangel}

By the same system of careful selection and breeding which accomplished so much with the Sugar Beet, there has been established in the Glant Feeding Sugar a strain of beets which, while giving nearly as large a yield of easily grown and harvested roots as a crop of Mangels, supplies a food of very much higher nutritive value. The roots for feeding purposes are really more valuable, pound for pound, than those of the very best strains of sugar beet and the yield under equally favorable conditions is more than double. The roots are of light bronze green color, grow partly out of the ground, and because of this and their shape the crop can be harvested and stored easily and at less expense than any other root crop. Ounce $5 \mathrm{c}$, 市 pound $10 \mathrm{c}$, pound $40 \mathrm{c}$

See illustration opposite.

\section{ROOT CROPS FOR FARM STOCK}

It is not what an animal eats but what it digests and assimilates, that is of benefit to the owner. When fed on a ration containing something green or fresh, appetite is stimulated; the digestion is improved and the general heaith and restful content greater. Root crops, in addition, contain high quantities of nutritive sugar, and are a necessity in rations of growing and fattening animals.

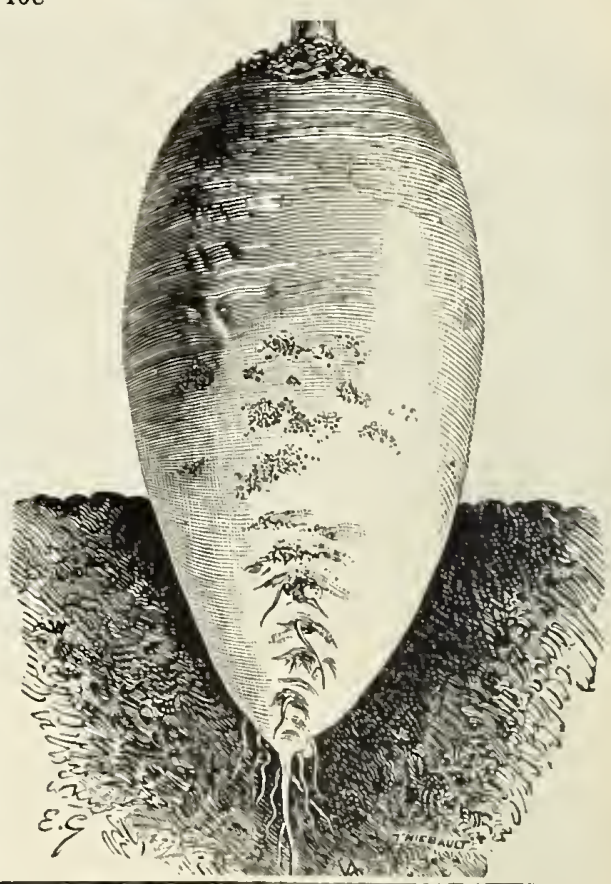

\section{Swiss Chard Beet or Summer Spinach. Nothing Better for the City Garden.}

No vegetable requires less care than this, and it is safe to say that none yields as constantly as this spinach, producing uninterruptedly from July until winter. Also called "Cut and Come Again Spinach". If your garden space is limited, this must have a place, for in ground occupied, Swiss Chard produces more food for the table than almost any other vegetable. The lea ves are used for greens the same as spinach or beet tops; they are equal in quality and easier to prepare than spinach, and far superior to beet greens. It can be used all summer when spinach is not available. Later the leaves grow very large, with broad, flat, pure white stems and mid-ribs which may be cooked like asparagus or made into very good pickles. Pkt 5c, oz. 10c, $\frac{2}{4} \mathrm{th} 20 \mathrm{c}$ 


\section{CABBAGE}

CULT URE. - For very early use sow in January or February in hotbeds; prick out when plants are strong enough into other hotbeds; or sow in cold frames in March, transplant to the open ground when danger from killing frosts is past, in rows 2 feet apart, and 18 inches apart in the rows. For a succession, sow in open ground the last of March or early in April. The autumn and winter varieties sow in April or early May, in shallow drills, 3 or 4 inches apart; transplant into rows $2 \frac{1}{2}$ feet apart, and 2 feet apart in the rows. Cabbage succeeds best in a fresh, rich soil, well manured, and deeply dug or plowed.

Cabbages should be hoed every week and the ground stirred as they advance in growth, drawing up a little earth to the plants each time until they begin to head, when they should be thoroughly cultivated and left to mature. Loosening the roots sometimes retards bursting of full grown heads.

Of late years many crops of early cabbage have been destroyed by maggots at the roots. The best remedy seems to be to remove the earth from around the stem and apply kerosene emulsion. The cabbage worms which destroy the leaves and beads may be killed by dusting with Slug Shot.

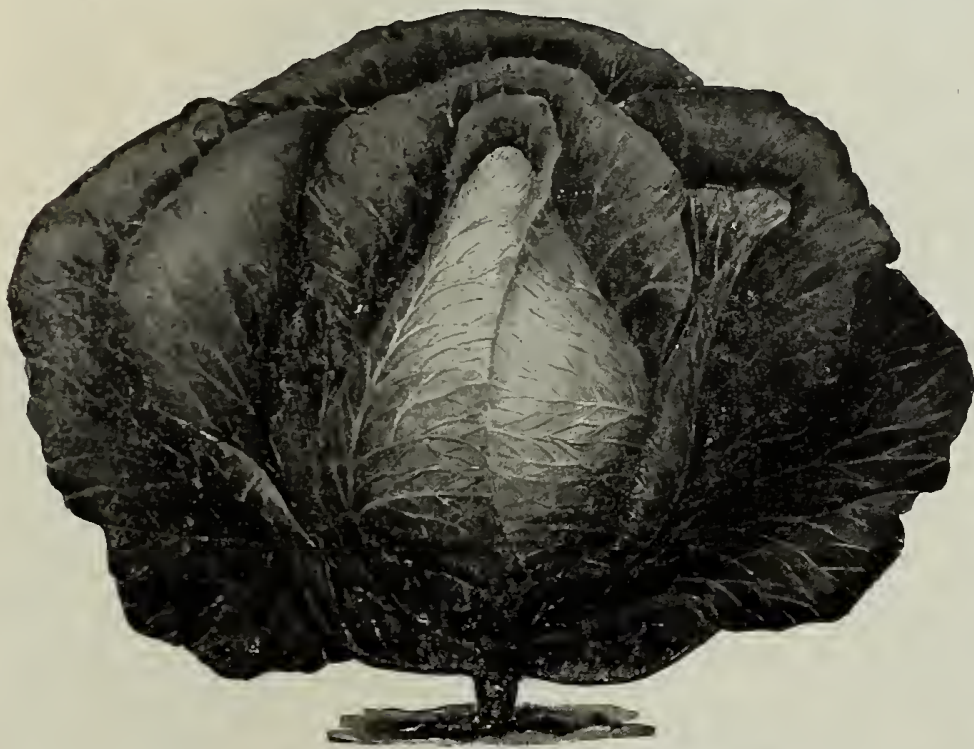

EARLY CABBAGE EARLY JERSEY WAKEFIELD THE EARLIEST AND HARDEST HEADING OF EXTRA EARLY CABBAGES

Among the many extra early $\nabla$ arieties there is none better adapted to American methods of culture and the American market than Early Jersey W a kefield. The plants are very hardy, not only to endure frost, but also unfavorable conditions of soil and moisture. It is safe to ship the heads younger than would be possible with most varieties, and at the same time they will remain in condition for use longer than ordinary early sorts. The leaves are thick, short and of fine quality. The best sort for very early setEARLY JERSEY W AKEFIELD CABBAGE ting. We offer a stock from carefully bred and selected plants, which is much superior to that ordinarily sold.

Packet 5c, ounce 25c, - pound $75 \mathrm{c}$

Pkt. Oz. $\quad+1 b$.

EARLY SPRING.-Becomes solid enough for use almost as early as Jersey Wakefield Similar in form to Flat Dutch. Short stem, compact head..................

CHARLESTON, OR LARGE WAKEFIELD.-Larger than the Jersey Wakefield, a little

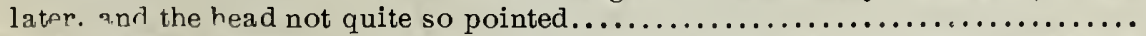

Henderson's Early Summer.-Is about 10 days later than Jersey W akefield. May be classed among the best large second early cabbages; round heads.............

Succession.-About one week later than Henderson's Early Summer, but somewhat

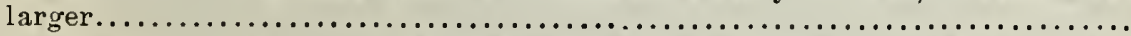

All Seasons.-It is as good for late market or winter as for early. Stands hot sun

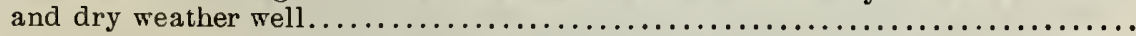

EARLIEST DANISH SUMMER BALLHEAD.-This is an entirely new cabbage, now offered for the first time. It is without a rival as the finest large, round headed, early cabbage, and will prove a most attractive sort especially for market purposes. It is extremely early-as early as Charleston Wakefield-but, notwithstanding this, the heads are large and solid and of very fine texture. They are ball-shaped, with but few outside leaves. The stem is of medium height. We believe this new cabbage will soon become as prominent among the early varieties as the "Hollander" ranks high among the later sorts.............

To preserve cabbages during winter, pull them up on a dry day, and turn them over on the heads a few hours to drain. Set them out in a cool cellar, or bury them in long trenches in a dry situation, covering with boards or straw so as to keep out frost and rain. 
W. E. DALIWIG 34-Juneau Ave. MILWAUKEE है

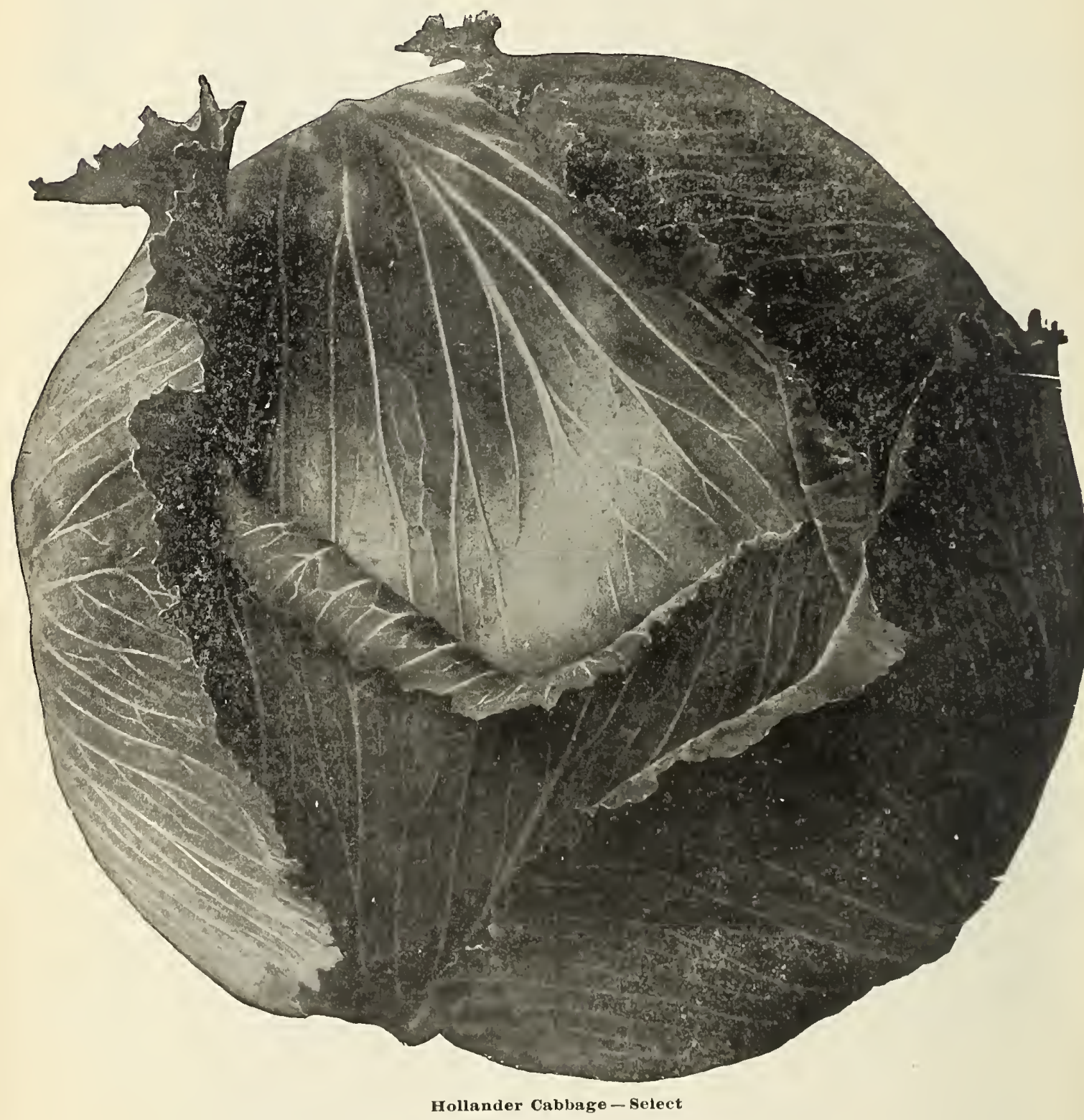




\section{LATE AUTUMN AND WINTER CABBAGE HOLLANDER CABBAGE..Select}

This variety came originally from Europe. The plant is very vigorous, rather compact growing, with a longer stem than most American sorts, and is exceedingly hardy, not only in resisting cold, but dry weather as well. The head is made up of very thick, broad lea ves which overlap each other more than most sorts. It is very solid, and stands shipment so well that it arrives at its destination in very attractive condition. In quality, it is one of the best, being very white, crisp and tender. We have given a great deal of attention to this variety and offer seed which we believe will produce a crop of more uniformly typical heads than can be grown from seed offered by any other dealer.

Packet 5c, ounce 25c, 亲 pound' $90 \mathrm{c}$, pound $\$ 3.00$ LONG KEEPING.-A very handsome and extreemly hardy cabbage; has proved to be one of our best winter sorts. The heads are of good marketable size, not quite so large as those of Flat Dutch, but very hard, round, fine-grained, and will weigh one-fourth more. Packet $5 \mathrm{c}$, ounce $25 \mathrm{c}$, $\frac{1}{4}$ pound $90 \mathrm{c}$ Large Late Flat Dutch.-Standard large, late, flat variety.

Packet 5c, ounce $15 \mathrm{c}$, $\frac{1}{4}$ pound $50 \mathrm{c}$

\section{RED CABBAGE. Dallwig's Early Dark Red. By tar the best medium-}

sized and surest heading early red cabbage. Color a deep, rich red. Many successful market gardeners choose this for their entire crop, pronouncing it the best of all. Pkt. 5c, oz. 25c, $\frac{1}{2} 1 \mathrm{t} 75 \mathrm{c}$

Large Red Hollander. The best late red cabbage. The heads are very solid, of the richest Large Red Hollander. deep blood-red, of good size, fine-ribbed and with few outer leaves. It matures medium late and is a splendid keeper. Mammoth Rock Red.-The heads are as large as the Early Summer, very solid, and of dark red color.

Packet 5c, ounce 20c, 文 pound 60c

\section{SAVOY CABBAGE}

Early Dwarf Ulm.- One of the earliest and sweetest of the Savoys. Heads round and solid; leaves small, thick, fleshy, of fine deep green color, and of most excellent quality.

Packet 5c, ounce 15c, t pound 50c Blumenthaler.-Early, yellow, curled.

Packet 5c, ounce $15 \mathrm{c}$, t pound $50 \mathrm{c}$ Large Late Vertus. - Late green curled. An excellent variety of fine $\mathrm{fl}$ a vor; heads large and showy.

Packet 5c, ounce 15c, pound 50c

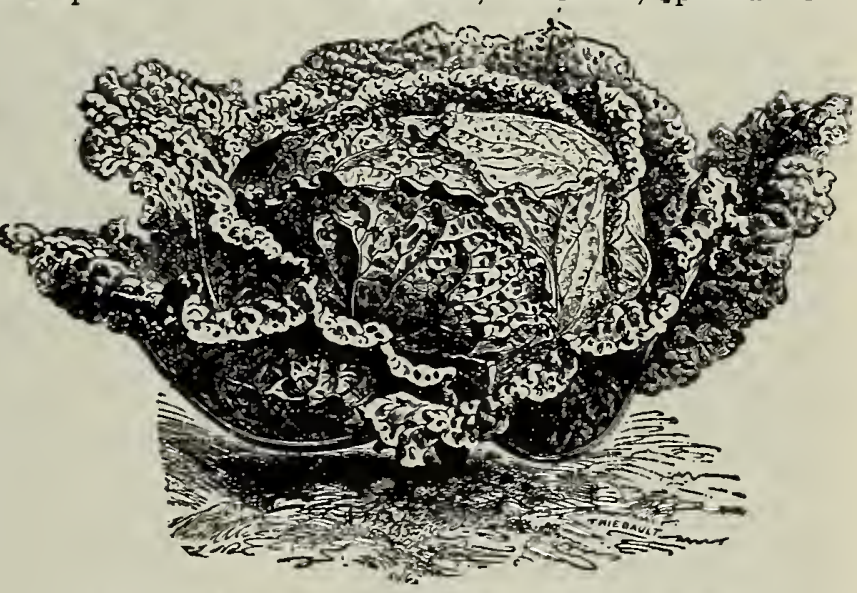

SA VOY CABBAGE, LATE GREEN CURLFD VERTUS

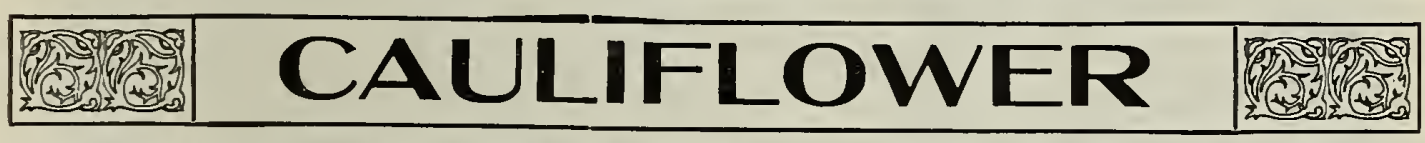

For spring and early summer use, sow about March 1st, in hot-bed, and transplant to cold frame when sufficiently large. and to the open ground as soon as ground is warm enough. For late autumn crop sow in the early part of May and transplant in June. In dry weather water freely, and as they advance in growth hoe deep and draw earth to thestem When heading tie outside leaves loosely over the heads to protect from the sun.

Haage's Earliest Dwarf. The best sort for forcing as well as for outdoor culture. It is exceedingly early and hardy and is the surest to make a solid, compact, large, pure white head, as it is remarkably drought and heat resisting.

Packet 15c, tounce $85 \mathrm{c}$, tounce $\$ 1.50$

Extra Early Dwarf Erfurt. Long the standard of highest excellence, and not surpassed by any variety for field culture. Large, firm, pure white. Plant short-jointed with narrow erect leaves. Our stock of this is the very finest obtainable anywhere.

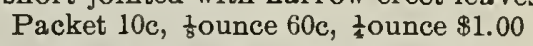
EARLY SNOWBALL.-Admirable in all good qualities; extra early, good size, pure white, dwarf in habit, with few outside leaves.

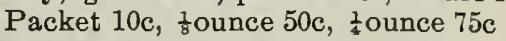

CRES G CURLED, or PEPPER GRASS.-This small salad is much used with lettuce, to CRES. which its warm, pungent taste makes a most agreeable addition. It may be sawn very early, but repeated sowings are necessary to secure a succession. Packet 5c, oz. 10c, $\frac{1}{4}$ to $20 \mathrm{c}$ 
W. E. DALLWIG 34-Juneau Ave. MILWAUKEE हु?

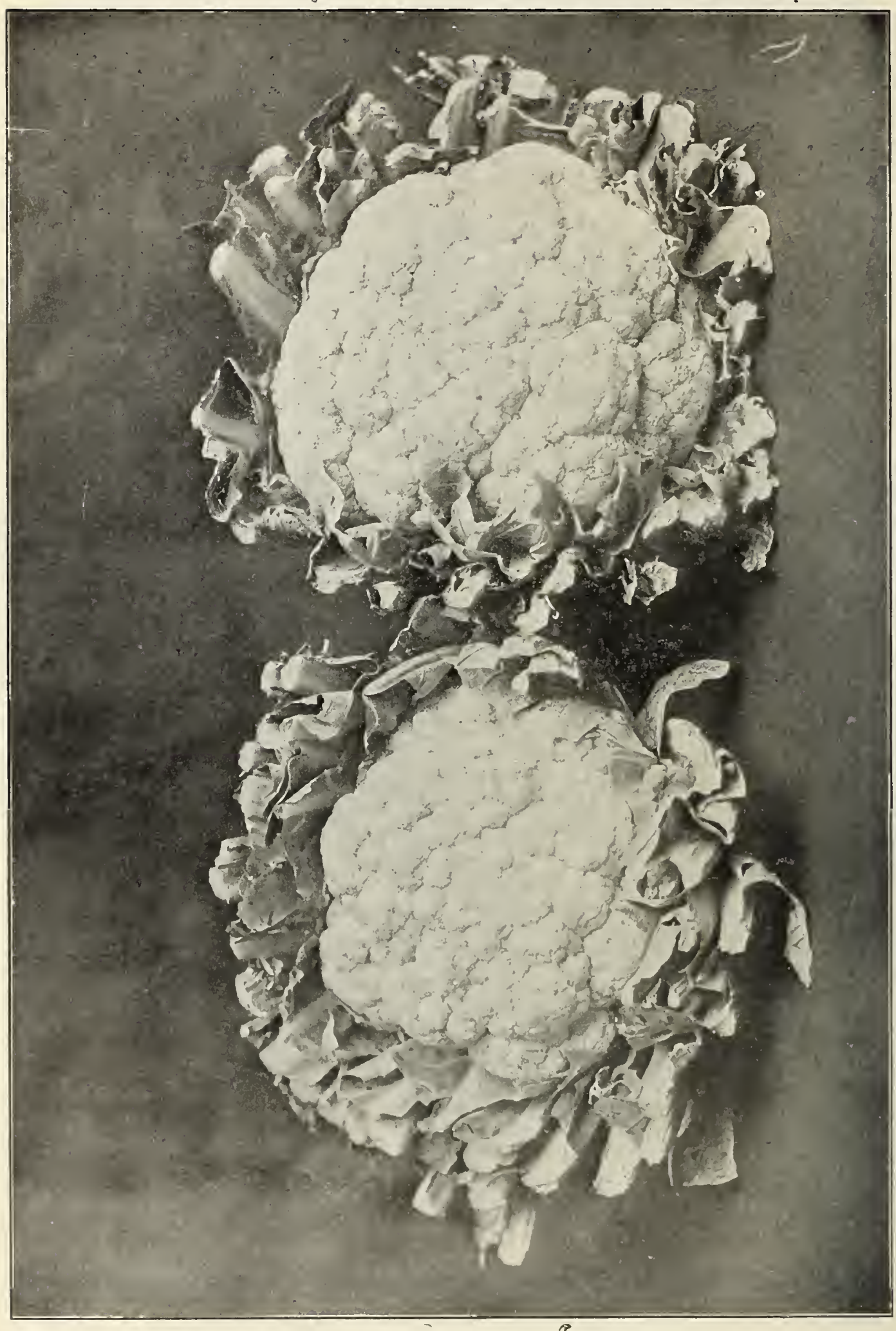

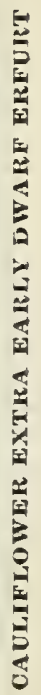




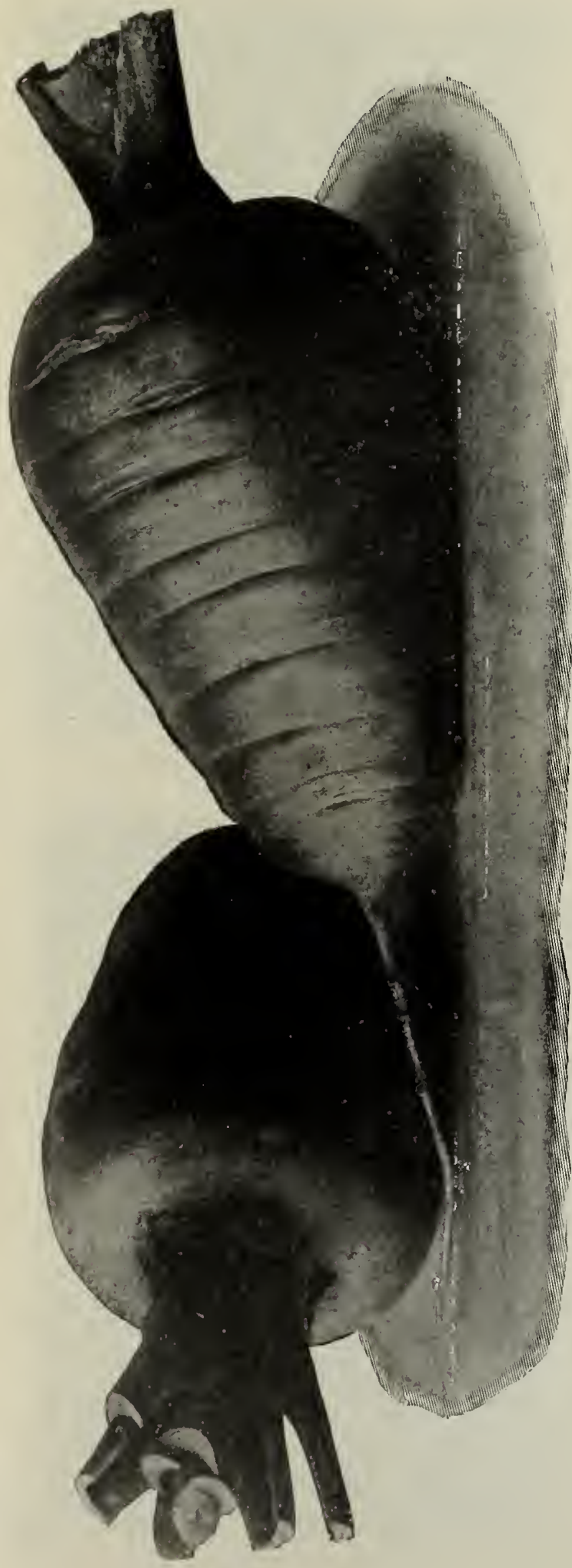

\section{CARROT}

One ounce 100 feet drill; 3 lbs. per acre. For early crops sow as soon as ground can be worked, in drills $1 / 2$ inch deep, and one foot a part ( 3 feet for field culture), from middle of May until first of July, thinning four to eight inches according to varieties. Keep your plants well cultivated.

HALF LONG SCARLET NANTES.- (Stump Rooted). Roots cylindrical, smooth, bright orange.

Early Half Long Scarlet Carentan.-The skin is smooth, flesh red, and without any core or heart.

SELECTED CHANTENAY OR MODEL.-This special strain of Chantenay Carrot is grown from selected, perfect roots only. It will run more uniform in shape and color than any other strain. It is the best early bunching Carrot, stump-rooted, smooth, deep color, and fine grained. A heavy cropper.

See illustration from photograph.

OX HEART OR GUERANDE. - It is interme. diate as to length between the half-long varieties, (such as Danvers) and Scarlet Horn, but much thicker, attaining a diameter of from three to four inches at the top. It is of fine quality for table use. Flesh fine grained bright orange, and sweet.

SELECT ORANGE DANVERS HALF LONG.This strain of Danvers Carrot is selected with greatest care. It runs remarkably true to the correct type, which is of deep orange color, of medium length, and tapering uniformly to a blunt point. Sweet, crisp, tender. ABOVE SORTS: Pkt. 5c, oz. 20c, $1 / 4 \mathrm{lb} .60 \mathrm{c}$ Large White Belglan and Large Yellow Belglan.-These grow to a very large size, and are excellent for stock feeding.

Pkt. 5c, oz. 10c, 1/4 pound 25 c, pound $75 \mathrm{c}$

\section{CELERY}

Celery can be successfully grown in any good garden soil, by using plenty of well rotted manure with a liberal sprinkling of coarse salt worked into it. It delights in low, moist, rich bottom land. $1 \mathrm{oz}$. to 2000 plants Go!den Self Blanchlng.-Close habit, compact growth and straight vigorous stalks. The ribs are perfectly solid, crisp, brittle, and of delicious flavor, surpassed by no other variety, while it has the decided merit of self-blanching to a very remarkable degree. The heart is large, solid and of beauiful rich golden yellow color.

Packet $10 \mathrm{c}$, oz. $75 \mathrm{c}, \mathrm{T} / 4$ pound $\$ 2.75$

White Plume.-Naturally white, so that if requires very little earthing up.

Evans' Triumph.-Large, white, crisp, brittle tender and fine flavored stalks. It is la te, and requires the whole season to develop.

winter Queen.-This is without doubt the most valuable variety of celery for winter and spring use ever introduced. Much stouter, thicker and heavier, with double the amount of heart of any known Celery. Blanches to a beautiful cream white. Ribs perfectly solid, crisp, and of a delicious nutty flavor.

Above sorts-Pkts. 5c, oz. $15 \mathrm{c}, 1 / 4$ lb. $50 \vec{c}$. 
W. E. DALLWIG 34-Juneau Ave. MILWAUKEE है⿴囗十)

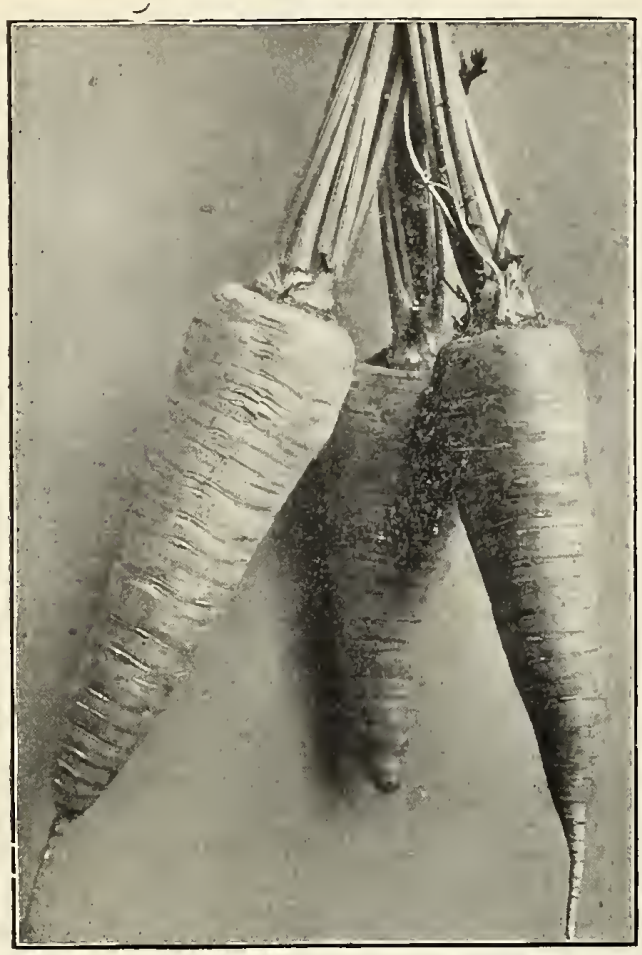

CARROT, Select Orange Danvers Half Long

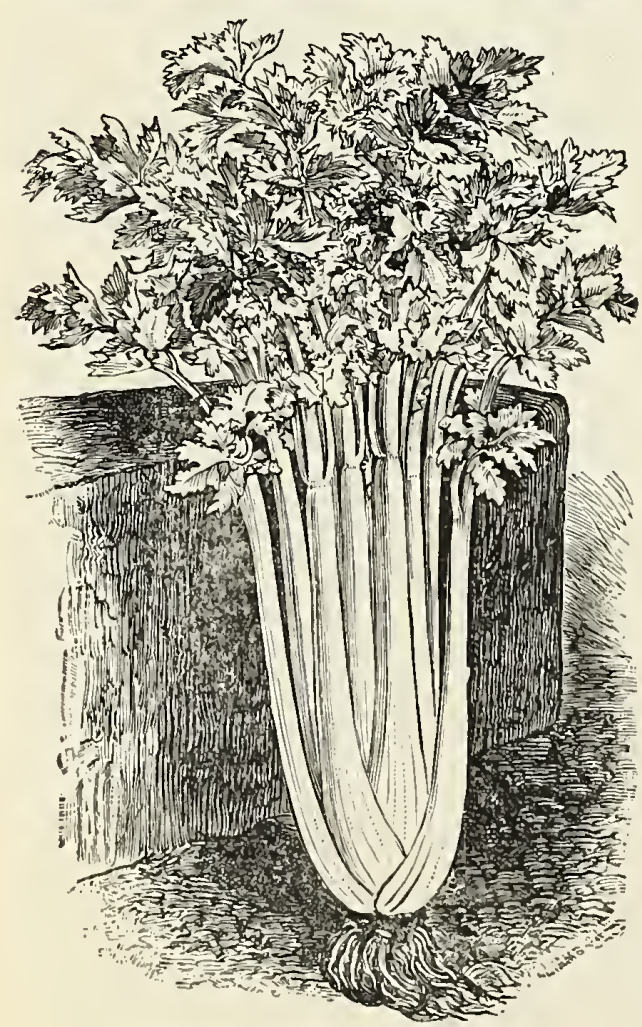

CELERY, Golden Self-Blanohing

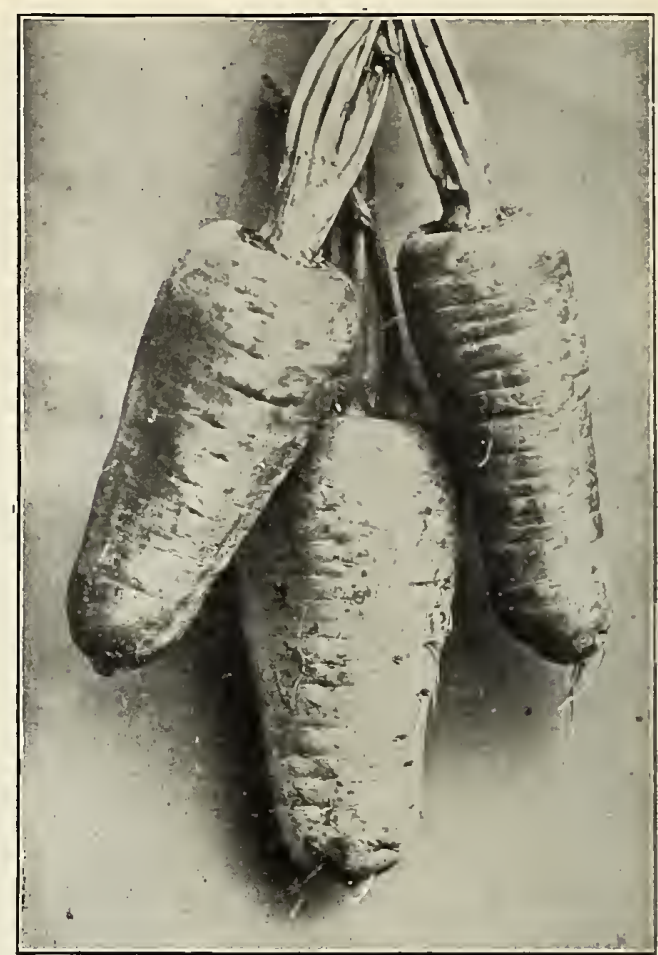

CARROT, Selected Chantenay

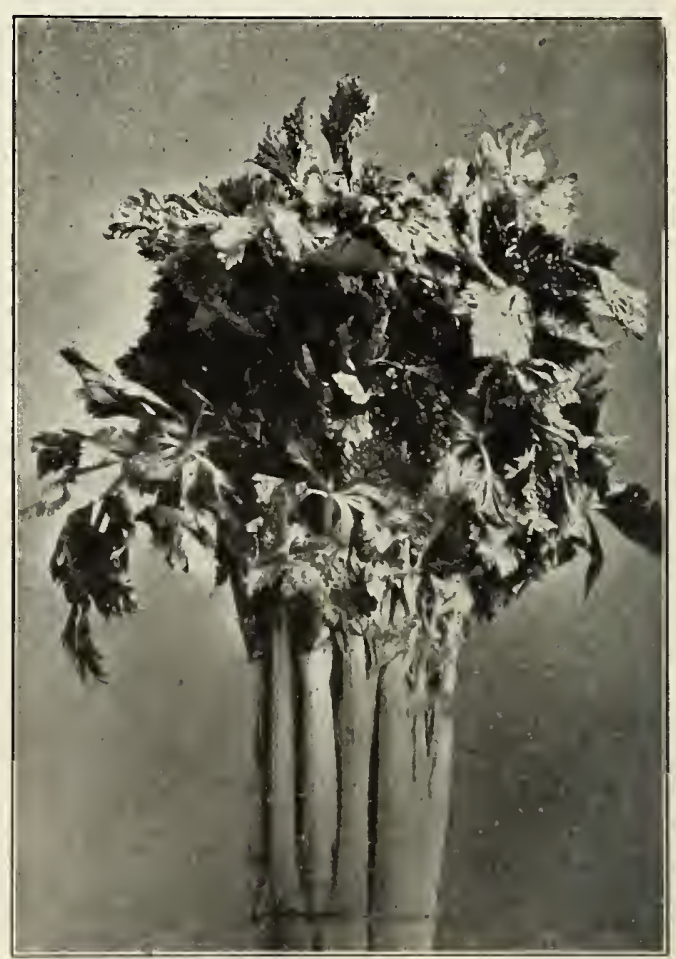

CELEIR, White Plume 


\section{CELERIAC Turrip Rooted}

A popular German vegetable. The roots, which are used in salads and in soups, have a pleasing celery flavor. Keeps well all winter. Give it a light, rich, deeply worked soil.

LARGE SMOOTH PRAGUE.-This is the largest celeriac, and the most popular with American growers. Produces large, smooth, almost globe shaped roots, with very few ride roots; flavor and quality are excellent. Plants vigorous, with large, deep green foliage.

Packet 5c, ounce $15 \mathrm{c}$, \& pound $50 \mathrm{c}$ DELICATESS.-Produces smooth oval shaped roots, without side roots. The flesh is snow-white, tender and of most delicious flavor, and never rusts. Will produce good roots even on poor soil.

Packet 5c, ounce 25c, t pound 75c

\section{CORN SALAD}

Broad Leaved. - Used as a small salad throughout the winter and spring. Sow thickly in drills, cover with straw or coarse litter with the approach of cold weather. Or sow in cold frames; thus it is accessible even when deep snow prevails.

Packet 5c, ounce 10c, pound 20c

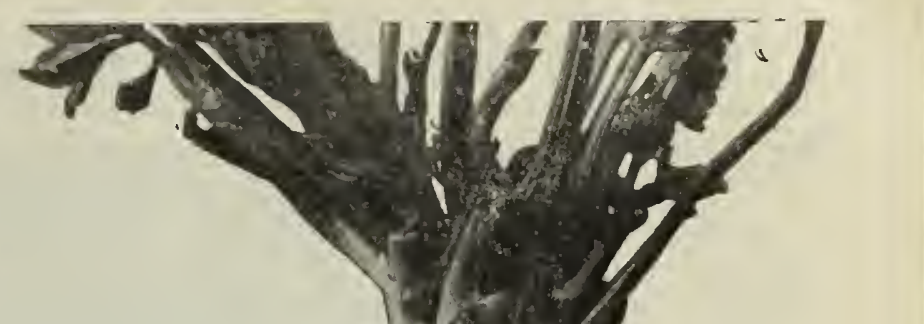

.


FOR TABLE USE. A rich, warm, aluvial soil is best, but excellent sweet deeply and thoroughly worked before planting. Give frequent and thoroug soil if it is Low cultivation until the tassels appear.

Mammoth White Corey.

The Largest and Best

ETRA GARLY SWEET CORN.

\section{NOTHING EARLIER, NOTHING BETTER, NOTHING LARGER,}

The ears are 12 rowed, much larger than the MAMMOTH WHITE COREY.
with large, white grains of good quality. The Beauty and Quality of this variety give it ready sale even when the market Is over stocked. Gardeners should not fail to make their first plautings of this best of extra early sorts. Packet $5 \mathrm{c}, 1 / 2$ pint $10 \mathrm{c}$, pint $15 \mathrm{c}$, quart $25 \mathrm{c}, 4$ quarts $75 \mathrm{c}$.

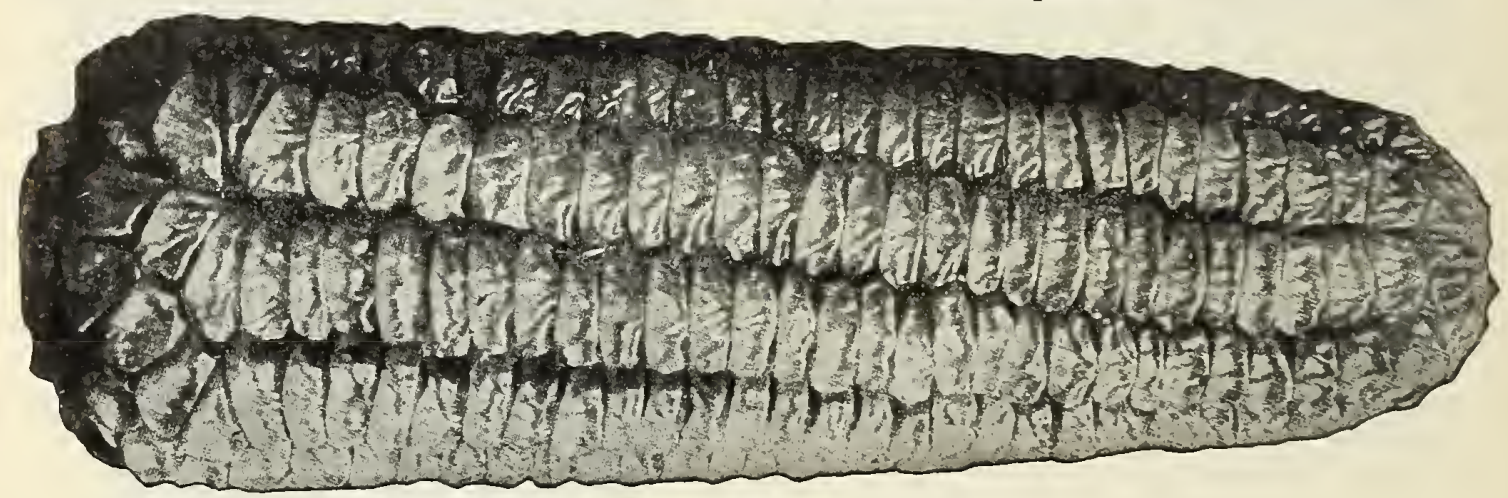

\section{PEEP O'DAY CORN}

PEEP O'DAY.- The two points in which this corn is most remarkable are its extraordinary earliness and unparalleled sweetness, surpassing in these particulars any other known variety. By arranging the plantings a week or two apart, you may have this delicious corn throughout the entire season. It is wonderfully productive, stalks bearing from two to five ears each.

Packet 5c, $\frac{1}{2}$ pint $10 \mathrm{c}$, pint $15 \mathrm{c}$, quart $25 \mathrm{c}, 4$ quarts $75 \mathrm{c}$

GOLDEN BANTAM.-ONE OF THE EARLIEST AND BEST OF EXTREME-EARLIES. DELICIOUS IN FLA VOR Exceptionally hard and firm, hence can be planted earlier than any other true Sweet Corn. Dwarf and sturdy, growing to a height of four feet, and bearing two and three good ears, five to six inches long, well filled to the extreme rounded tip with eight rows of broad yellow grains. As distinct in flavor from that of white varieties as in color, - being almost literally "sweet as hon $\in \mathrm{y}$ ".

Packet 5c, $\frac{1}{2}$ pint $15 \mathrm{c}$, pint $20 \mathrm{c}$, quart $40 \mathrm{c}, 2$ quarts $75 \mathrm{c}, 4$ quarts $\$ 1.25$

COUNTRY GENTLEMAN.-One of the finest sweet corns for private use. A short stalked, productive sort, frequently producing three ears to the plant. Ears large for so small a stalk; grain narrow and very deep, after form of shoe-peg. Highly recommended as one of the very best.

Packet 5c, $\frac{1}{2}$ pint $10 \mathrm{c}$, pint $15 \mathrm{c}$, quart $25 \mathrm{c}, 4$ quarts $75 \mathrm{c}$

Eariy Evergreen.-A valuable variety for market gardeners and the home garden. It ripens 10 days in advance of Stowell's Evergreen, and in quality is fully as good. Ears about 8 inches long with 12 or more rows of kernels, which are sweet and tender. Pkt. 5c, $\frac{1}{2}$ pt. 10c, pt. 15c, qt. 25c, 4 qts. $75 \mathrm{c}$ Early Minnesota.-An old favorite variety of excellent quality; large white grains; extremely productive.

Packet 5c, $\frac{1}{2}$ pint $10 \mathrm{c}$, pint $15 \mathrm{c}$, quart $25 \mathrm{c}, 4$ quarts $75 \mathrm{c}$

Black Mexican.-A medium early variety which, on account of its deliciously sweet and fine grained quality, is becoming more of a favorite every year. For the home garden it is very desirable.

Packet 5c, $\frac{1}{2}$ pint $10 \mathrm{c}$, pint $15 \mathrm{c}$, quart $25 \mathrm{c}, 4$ quarts $75 \mathrm{c}$

Stowell's Evergreen.-The most popular late variety. Remarkably prolific, bearing large, finely flavored ears with deep kernels, white in color. Excellent for market.

Packet 5c, $\frac{1}{2}$ pint $10 \mathrm{c}$, pint $15 \mathrm{c}$, quart 25c, 4 quarts $75 \mathrm{c}$

All of our Sweet Corn is hand-picked, all imperfect and under-sized seeds being carefully removed. IF SWEET CORN IS WANTED BY MAIL, ADD 5 CENTS PER PINT, 10 CENTS PER QUART FOR POSTAGE. 


\section{$C \cup C \cup M B E R S$}

The Cucumber is a tender annual and should never be planted in open ground unless settled weather arrives, for general crop about the middle of May. For pickles, plant from middle of June to the middle of July. By far the hest results are obtained from plantings in warm, rich sandy loam. Prepare hills 4 feet apart each way. and mix with the soil of each a shovelful of well rotted compost. Sow thickly, and when all
danger of insects is past ("Slug Shot" is sure death to the striped cucumber beetle), thin out all but three or four of the stockiest vines in each hill. As the cucumbers attain a sufficient size, both the perfect and the imperfect specimens should be picked at once, as fruit left upon the vines to ripen soon destroy's their vitality, and consequently their productiveness.

IMPROVED EARLY WHITE SPINE.-Uniformly straight and handsome dark green with a few white spines.

ARLINGTON WHITE SPINE.-A strain of White Spine especially recommended for fine shape, uniformity of size, and dark green color. Desirable sort for forcing.

EVERGREEN, OR LONG WHITE SPINE.-The vine is vigorous and productive. The fruit is long,

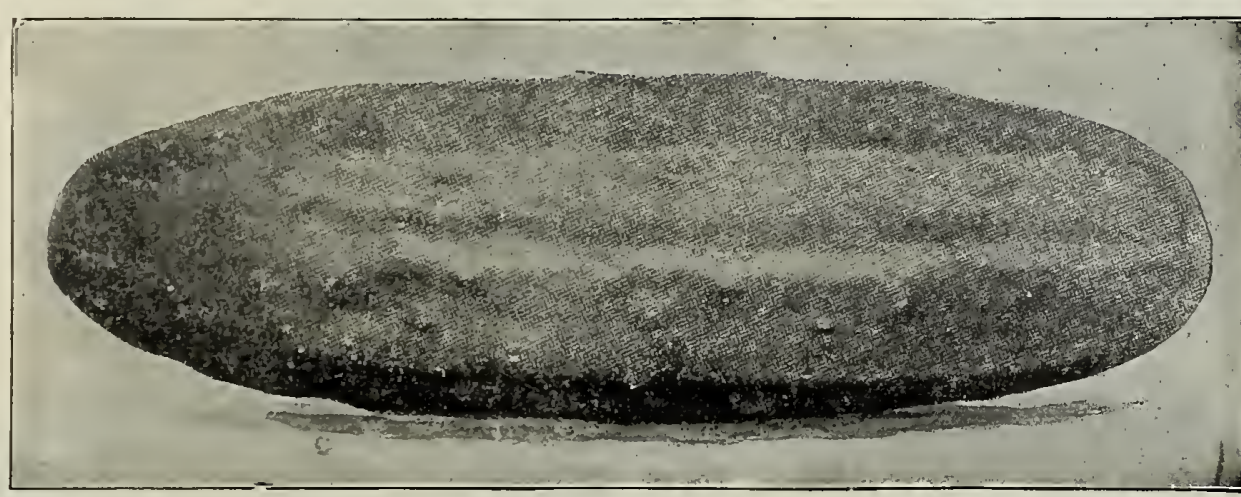
cylindrical, dark green, with white $3 \mathrm{risp}$ and tender flesh. Always remains deep green color. Best slicing sort. Excellent for culture under glass.

Fordhook Famous.-

EVERGREEN WHITE SPINE

The fruit is perfectly

smooth and very dark green, 12 to 17 inches long, straight and solid. Flesh greenish-white. firm and crisp, an enormous cropper and a handsome table fruit, which never turns yellow.

IMPROVED LONG GREEN.-A standard sort for outdoor culture; dark green, firm and crisp, tender and very productive; of uniform size, about twelve inches long. We offer a carefully selected strain.

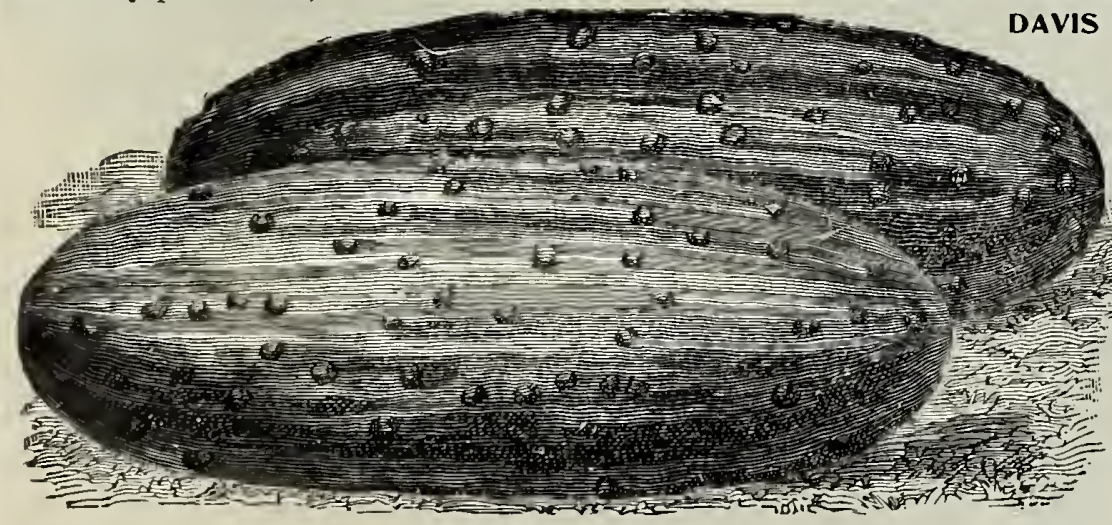

NICHOL'S MEDIUM GREEN

ERFECT. - The best cumber of the extra long white spine type Selected for length, slimness and its dark green color. A vigorous grower and a prolific yielder, besides resisting blight longer than most. It is equally valuable for indoor, frame, and outdoor planting.

Nichol's Medium Green.-It is always straight and smooth,

dark green, tender and crisp.

Chicago Pickle.--Undoubtedly the best cucumber for pickles. Fruit of medium length, pointed at both ends, with large and prominent spines; color deep green.

Jersey Pickle.- Very crisp and tender. Said to "green" better than any other variety.

PRESSING PERFECTED PICKLING.-We believe this new cucumber is just what many picklers want, short pickles which will pack in bottles better than other varieties. The small cucumbers of this splendid new variety are short, cylindrical and blunt ended, making when packed in bottles, very handsome, showy pickles of the very best quality. The vines are vigorous, setting their fruit early and are very productive.

Burpee's Giant Pera.-Very smooth and straight; the skin is a beautiful medium green, perfectly smooth, free from spines, and retains its clear green color until ripe. They are very thick through, perfectly round, and from 15 to 18 inches long when matured. Packet $5 \mathrm{c}$, ounce $15 \mathrm{c}$, $\frac{1}{4}$ pound $35 \mathrm{c}$ Japanese Climblng.-Ten to twelve inches long, of fine green color; extra long vine. Very prolific.

Packet $5 \mathrm{c}$, ounce $15 \mathrm{c}$, $\frac{1}{\mathrm{t}}$ pound $40 \mathrm{c}$

All varieties of Cucumbers except where noted, packet 5c, ounce 10c, $\frac{1}{4}$ pound $30 \mathrm{c}$, pound $90 \mathrm{c}$ 


W. E.DALIWIG 34-Juneau Ave. MILWAUKEE है
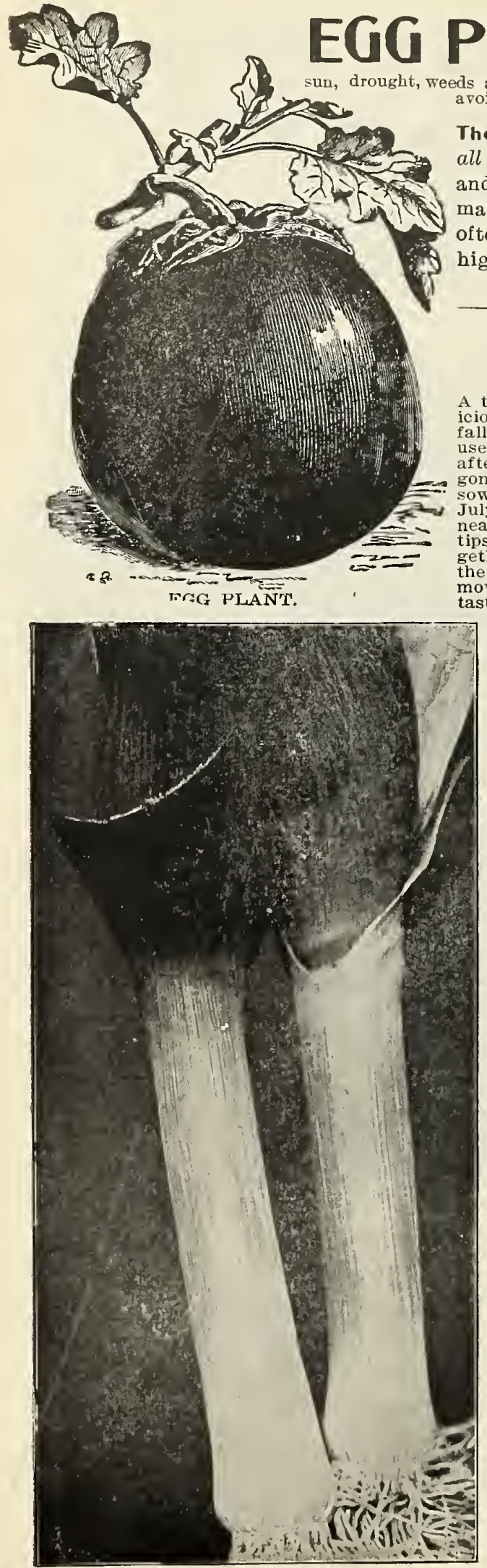

Yellow

Broad Leaf.

Green

Broad Leaf.

Green

Broad Leaf, with Curled

Edge.

DALLWIG'S

YELLOW

Should be sown, if possible in a hot bed, or in a warm light room in March and ported about June 1. Carefully protect from intense A tender and delfall and winter after comes in gone. Should be July and when gether to blanch the heart and remove the bitter Throughout its growth take every precaution to

Thornless Round Purple.-This variety has about superseded quality of its fruit and its extreme productiveness

CURLED. - A very beautiful sort in which the leaves are very light colored. Plants moderately dense with divided leaves.

DALLWIG'S GREEN CURLED. - The leaves are bea utifully cut and curled, easily blanched, and become very crisp, tender and fine flavored.

ALL VARIETIES: Packet 5c, ounce 15c, 1/4 to 40c

KOHIRAB Sow in light, rich soil, in KOHLRABI. arills 12inches a part, and when well established, thin to 6 inches apart in row. Dallwig's Star of the Market.-Much superior to Vienna. It is very early, and is the best for forcing as well as for outdoor culture. Bulb greenish white, smooth, of finest texture and quality. Favorite Market Gardener variety. Pkt. 5c, oz. 20c, th $75 \mathrm{c}$

EARLIEST SHORT LEAVED PURPLE.-Extra for forcing. Similar to above, except in color.

Packet $5 \mathrm{c}$, ounce $20 \mathrm{c}$, $\frac{1}{6}$ pound $75 \mathrm{c}$

Early White Vienna. ) Good market sorts.

Early Purple Vienna. $\{$ Packet $5 \mathrm{c}$, ounce $15 \mathrm{c}$, 1 th $50 \mathrm{c}$

Late Glant White.-Packet $5 \mathrm{c}$, ounce $15 \mathrm{c}$, $\frac{1}{4}$ pound $50 \mathrm{c}$

Late Giant Purple.-Packet 5c, ounce 20c, $\frac{1}{4}$ pound $60 \mathrm{c}$

EFK Sow very early in drills $\frac{1}{3}$ inch deep. LEL. Thin to 1 inch. When 8 inches high, transplant in rows 10 in. apart, as deep as possible. Giant Carentan.-A mammoth growing variety of excellent quality, becoming very white and tender.

Musselburg.-Grows to large size; mild and pleasant 
W. E. DALLWIG 34-Juneau Ave. MILWAUKEE

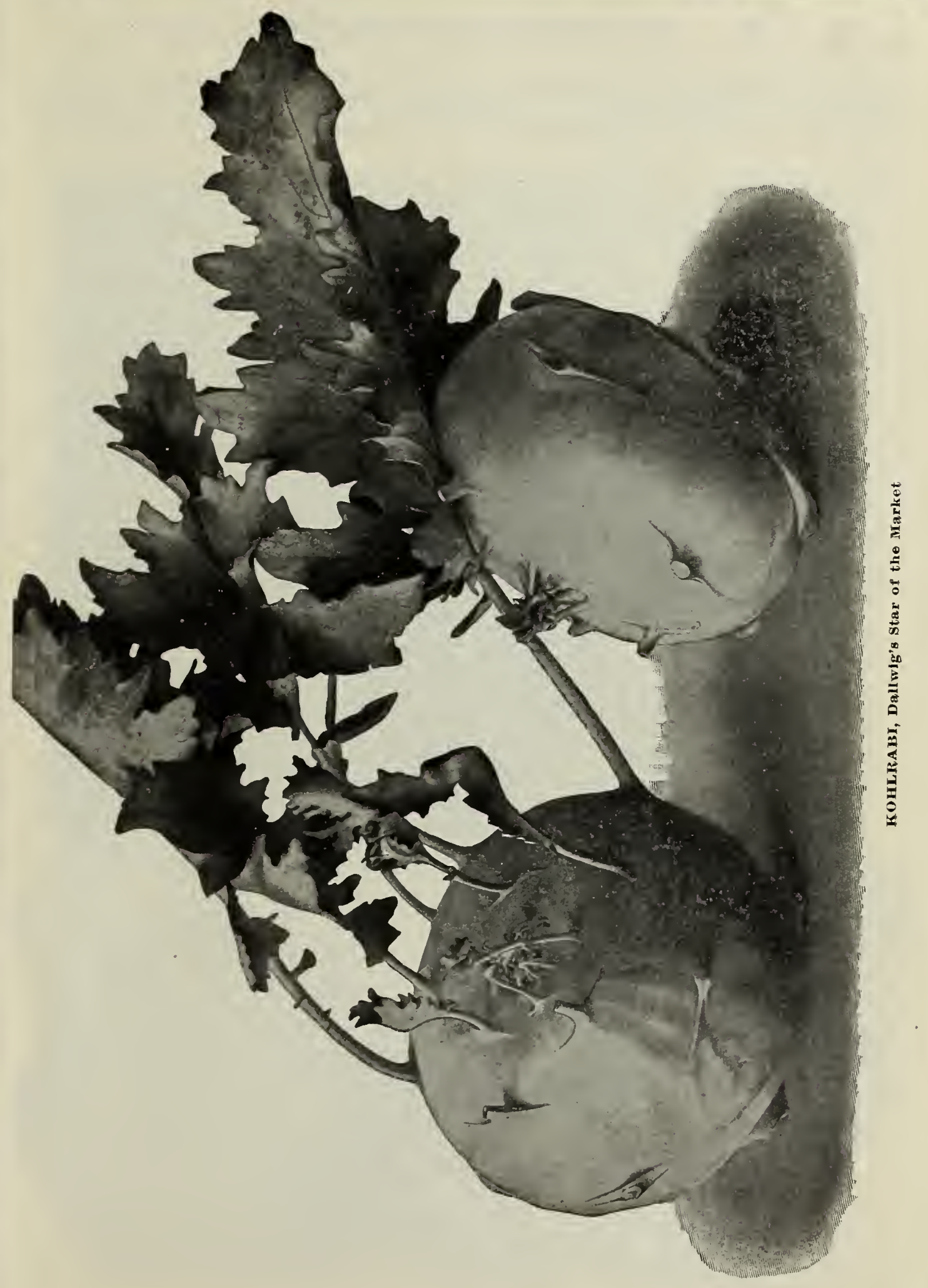




W. E. DALLWIG 34-Juneau Ave. MILWAUKEE है?

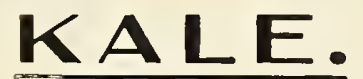

$1 \mathrm{oz}$. to 1,500 plants. Seeds may be sown in a moderately rich soil, in an exposed situation, in April or May. In transplanting treat the plants like young cabbages. The center leaves are used as spinach, and are much improved by frost.

Dallwigs's Dwarf Green Curled.-Plant low and compact, but with large leaves curled, bunch of moss. It would be well worthy of its cultivation simply for its beauty. One of the best sorts for use, and when grown and cooked is one of the most palatable of vegetables. (See half-tone plate5).

Packet $5 \mathrm{c}$, ounce $15 \mathrm{c}$

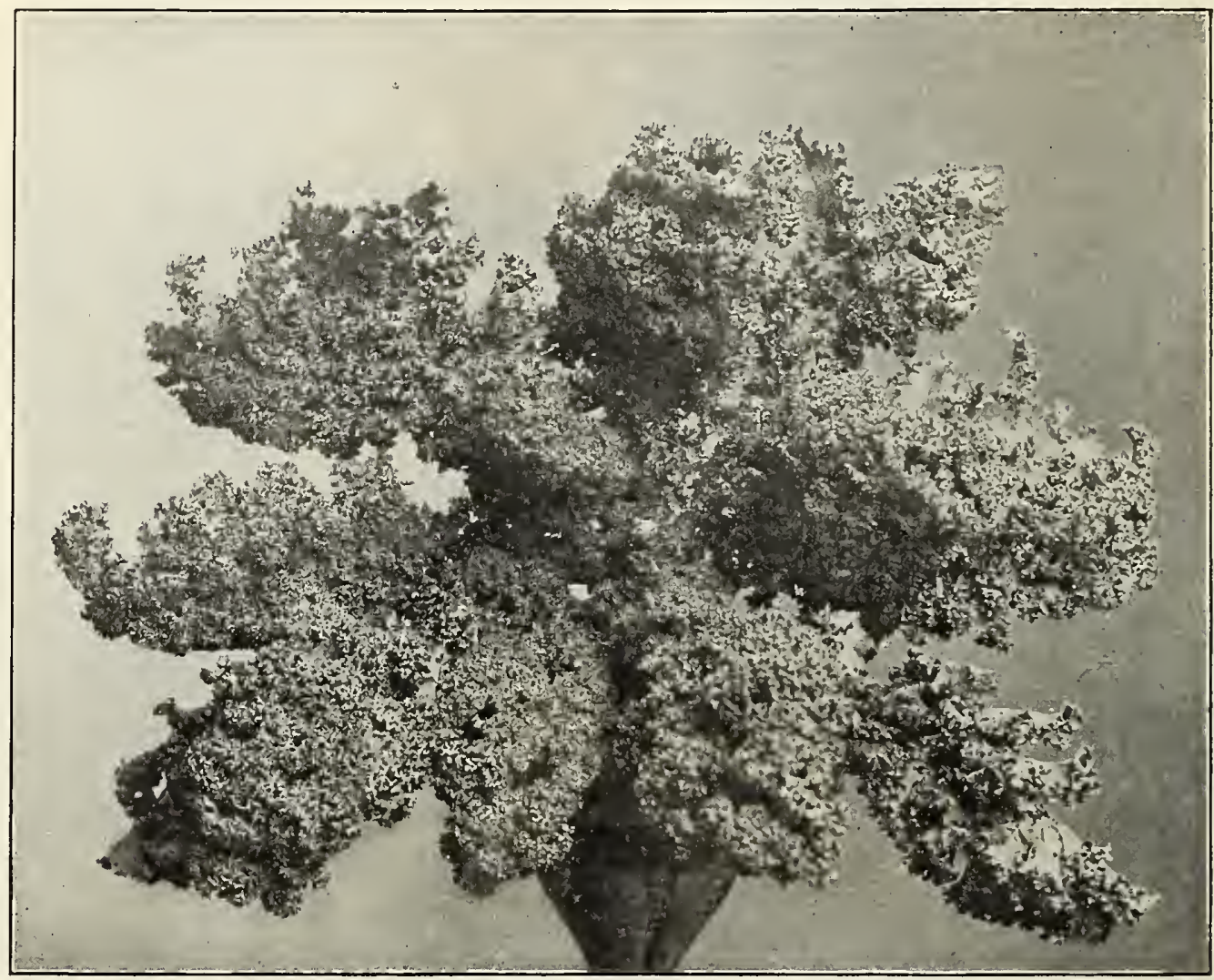

Ka LE, Dall wig's Dwarf Green Curled

\section{LETTUUCE LOOSE LEAVED LETTUCE VARIETIES}

\section{One Ounce will Sow 150 feet of Row}

Black Seeded Simpson.- One of the best ular varieties, as it is attractive, of excellent quality, and continues a long time in condition for use. Packet $5 \mathrm{c}$, ounce $10 \mathrm{c}, 1 / 4$ pound $25 \mathrm{c}$

Grand Rapids. -The best sort for shipping. ing and ventilation, will grow more weight on the same ground and will stand longer after matured, than any other sort. Of handsome appearance, a strong grower, and not apt to rot, and will keep from wilting longer while exposed for sale than any other sort. The seed we offer is true Grand Earliest Cutting.-Medium sized, early variety for cutting, keeps right on growing. Pkt. 5c, oz. 10c

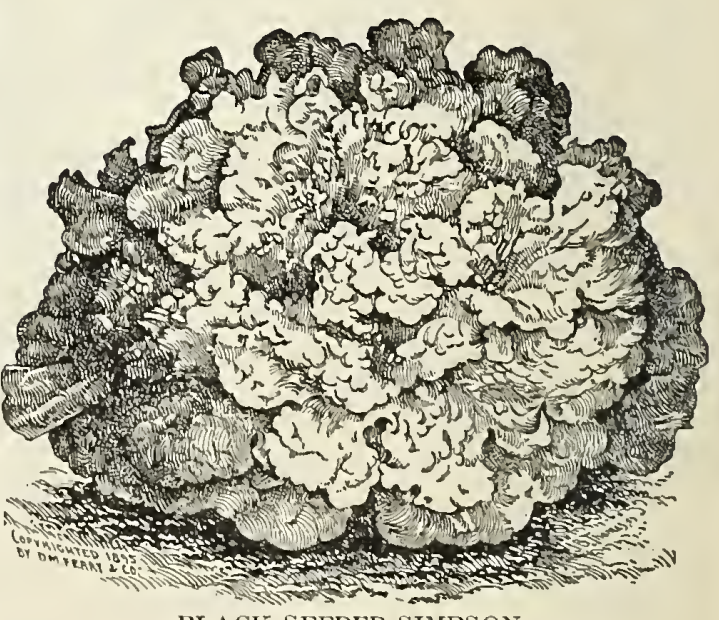

BLACK SEEDED SIMPSON. 


\section{HEAD LETTUCE}

Forcing.-An excellent forcing sort of the butter class. For compactness, solidity and fine form no variety is more desirable.

Packet 5c, ounce $15 \mathrm{c}, 1 / 4$ pound $50 \mathrm{c}$

May King.--Superior early heading sort. Light green head, inner leaves blanched to a rich golden yellow.

Packet $5 \mathrm{c}$, ounce $15 \mathrm{c}, 1 / 4$ pound $40 \mathrm{c}$

Stonehead Golden Yellow.--Rich golden yellow. Heads rather small, but very compact and solid, and of superb quality.

Packet 5c, ounce $20 \mathrm{c}$, $1 / 4$ pound $60 \mathrm{c}$

All Seasons.-Large, handsome, extremely solid head; color light grayish green; leaves broad and the head being large, the inner leaves are beautifully blanched; very slow to run to seed; sure heading; quality excellent, decidedly buttery with thick leaves. Packet 5c, ounce 15c, 1/4 pound 35c

Stubborn Headed Yellow.-One of the best for general use.

Packet 5c, ounce $15 \mathrm{c}, 1 / 4$ pound $40 \mathrm{c}$

Stubborn Headed Brown-Bright brown, interspersed very strikingly with bright green in less exposed or in depressed parts. Buttery and tender.

Packet $5 \mathrm{c}$, ounce $20 \mathrm{c}, 1 / 4$ pound $55 \mathrm{c}$

Select Big Boston.-Superior to the ordinary Big Boston; a very fine strain. Plants large, very hardy and vigorous. Color a light green, edges slightly tinged with reddish brown. Usually heads up under cold weather conditions better than others. Packet 5c, ounce 15c, 1/4 pound 40c

Erfurt Mammoth Yellow.-Large and very firm. Leaves yellowish green bordered yellowish white. Quality excellent; delicate, sweet, buttery in flavor. Packet 5c, ounce 20c, 1/4 pound 65c Defiance Summer.-Stands heat better than most others. Very large solid heads of yellowish green color.

Packet 5c, ounce $15 \mathrm{c}, 1 / 4$ pound $45 \mathrm{c}$

German Incomparable.-Very large and solid. Edges of leaves tinged brown. Of especial value on account of its long standing qualities.

Packet 5c, ounce $15 \mathrm{c}, 1 / 4$ pound $50 \mathrm{c}$

Mammoth Black Seeded Butter.-Large, solid yellow heads. Packet 5c, ounce $15 \mathrm{c}, 1 / 4$ pound $45 \mathrm{c}$

Golden Spotted.- Golden yellow, beautifully spotted brown. Packet 5c, ounce 15c, $1 / 4$ pound 50c Salamander.-Good-sized compact heads; withstands drought and heat. Pkt. 5c, oz. 10c, 1/4 Ib 30c

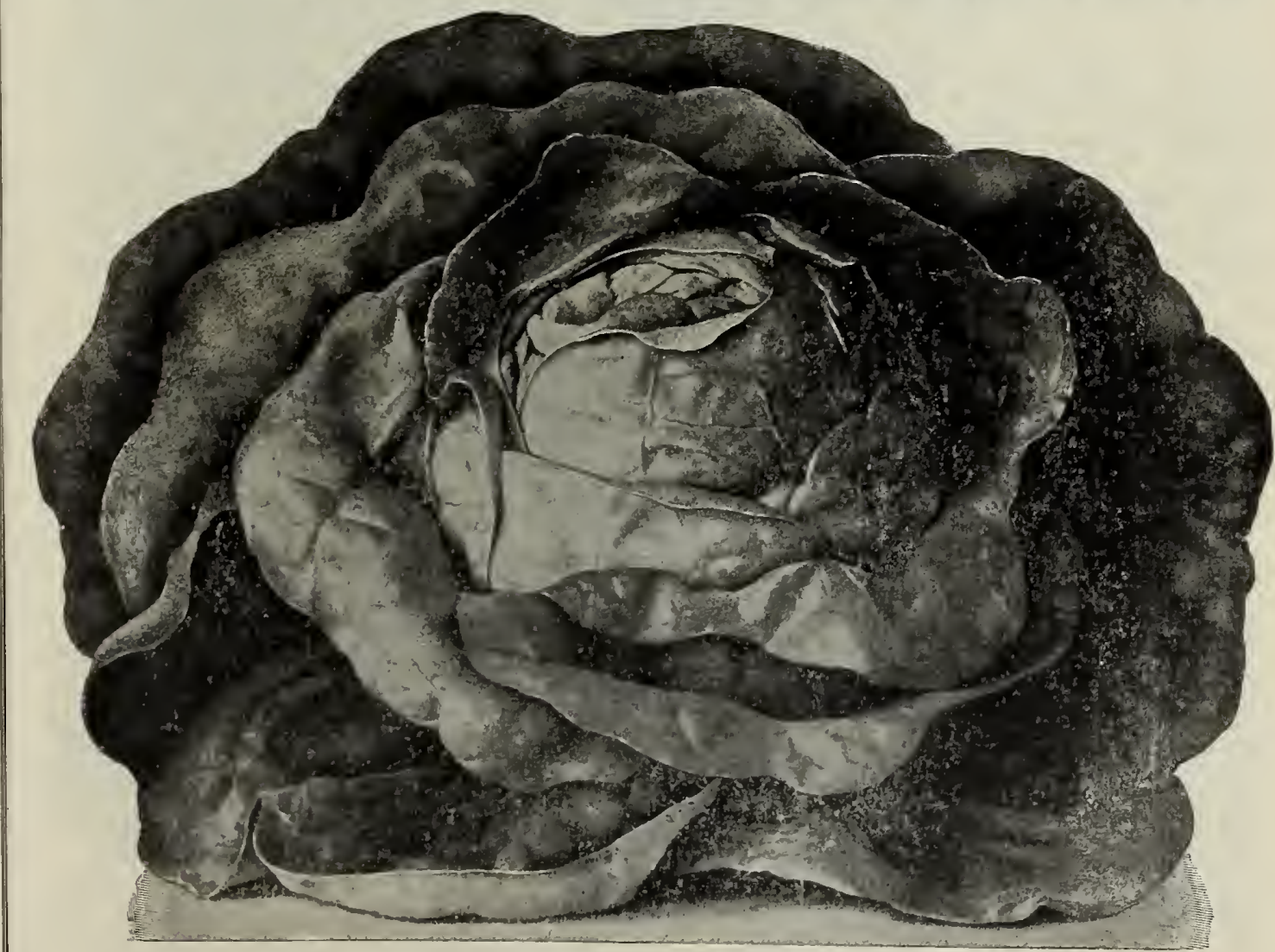

Head Lettuce, May King 


\section{W. E. DALLWIG 34-Juneau Ave. MILWAUKEE}

\section{WATER MELON}

Extra Early.-Fine qualty; very early and therefor suitable for northern climates; medium size; flesh bright red. Packet $5 \mathrm{c}$, ounce $10 \mathrm{c}$, $\frac{1}{6}$ pound $25 \mathrm{c}$

Sweet Heart. - A popular shipping melon. Large, oval, very heavy; rind thin but firm. Flesh bright red, firm but very tender, melting and sweet.

Preserving Citron.-A round melon used for preserving. Packet $5 \mathrm{c}$, ounce $10 \mathrm{c}$, $\frac{1}{6}$ pound $20 \mathrm{c}$ Packet 5c, ounce $10 \mathrm{c}$, $\frac{1}{4}$ pound $20 \mathrm{c}$

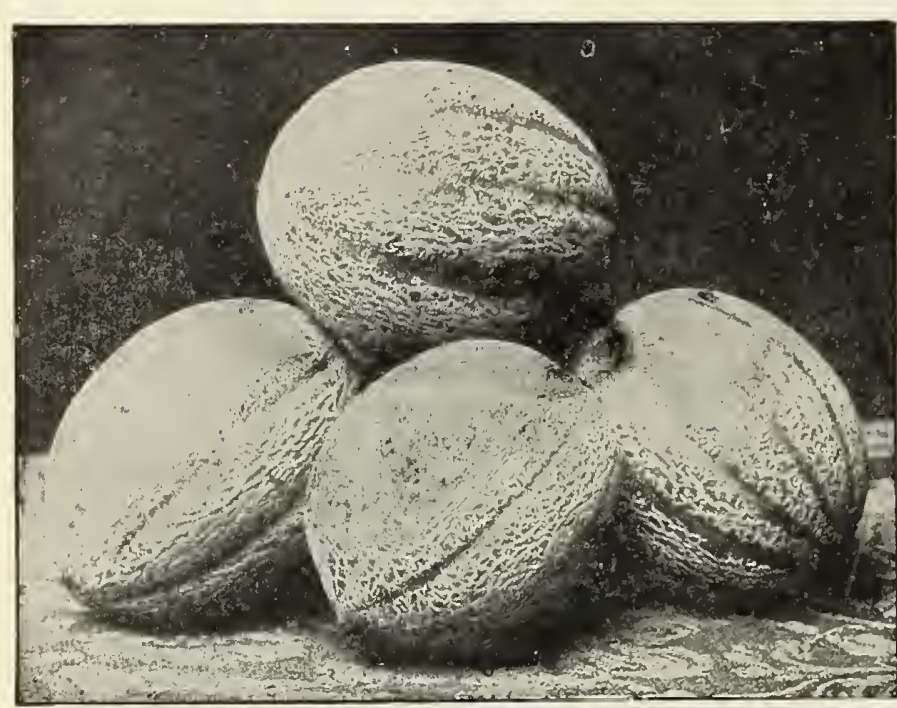

ROCKY FORD.

\section{MUSK MELON}

Musk Melons thrive best in a warm, rich sandy loam. After thorough spading or plowing make hills 5 feet apart each way, and mix with the soil of each 2 shovelsful of well rotted compost. As soon as warm weather becomes established, plant 12 seeds in a hill; thin out when all danger from insects has passed, leaving 3 of the stockıest plants to a hill. Use Slug Shot to. kill bugs.

\section{Green-Fleshed Sorts}

Champion Market.-Large, almost. perfect globe, densely netted, light. green, sweet flavored.

Early Hackensack.-Very sweet and juicy.

Montreal.-Large light green; late. Netted Gem.-Thick-meated, fine luscious flavor; very early.

Netted Nutmeg.-Sweet green, very early.

Rocky Ford.-Has attained national fame for dainty appearance, excellent quality and delicacy of flavor. Flesh light green,exceedingly sweet, and fine grained.

\section{YELLOW - FLESHED VARIETIES}

Osage.-Exceedingly sweet and high-flavored. The most popular of all, and styled the "Queen of Melons". Slightly netted, medium sized and cocoanut-shaped. Flesh of rich salmon color.

Tip Top. Tip Top in Quality Tip Top in Appearance Tip Top in Productiveness Sweet, juicy, finest flavor, firm (but not hard) fleshed, and edible even to the outside coating. The fruit is of large size, nearly round, evenly ribbed and moderately netted.
Paul Rose. Handsome Shape Good Shipper

The fruit is oval, about five inches in diameter. The firm flesh is a rich orange red color. The firm solid flesh and strong rind make it the best shipper we know of, while it is just the size for hotel and table use. PRICES

ALL MELONS LISTED ON THIS PAGE

Packet 5c, ounce $10 \mathrm{c}$, $1 / 4$ pound $30 \mathrm{c}$

\section{MUSTARD}

White London.-Best for salads. $1 / 4$ pound $10 \mathrm{c}$, pound $20 \mathrm{c}$

\section{OKRA}

Cultivated for its

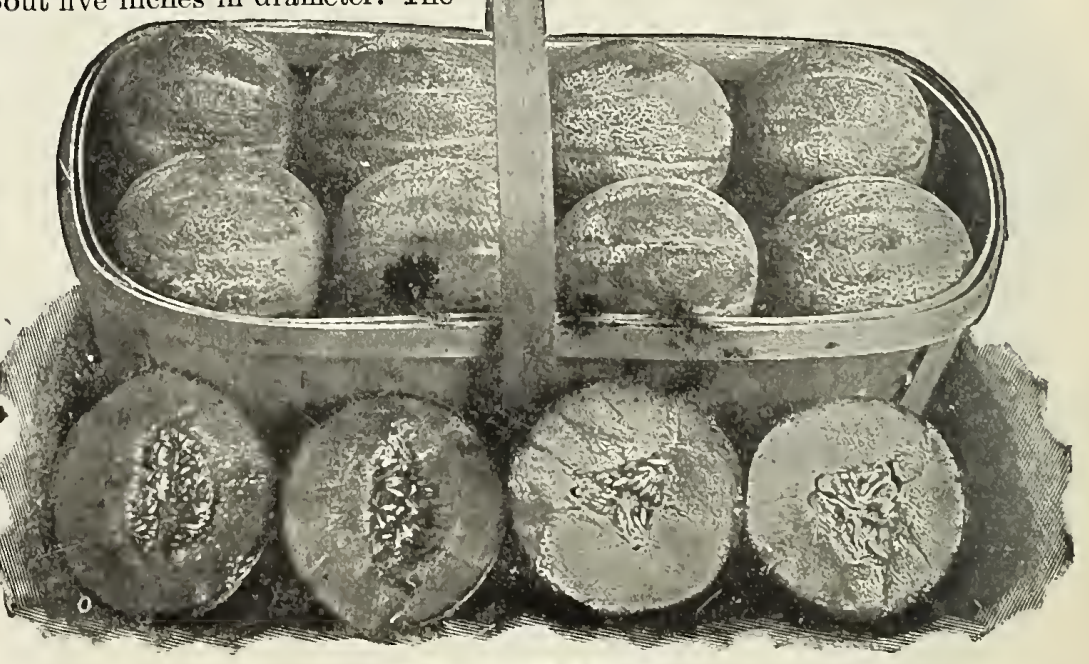

PAUL ROSE MELON.

young seed pods which are used in soups or stewed and served like asparagus. The pods, when young and tender, may be sliced in sections and strung on a thread and hung up in the shade to cure; in this condition they can be used for soup at any time. Packet 5c, ounce 10c, $1 / 4$ pound 20c 


\begin{tabular}{|l|l|l|}
\hline OUR STOCK IS FULLY EQUAL TO ANY AND SUPER- \\
IOR IN QUALITY TO MOST THAT IS OFFERED.
\end{tabular}

A deep. rich loam is best suited to Onions. The ground should be heavily dressed with well-rotted manure, and plowed a moderate depth, taking a narrow furrow in order to more thoroughily mix the manure with the soil; if possible the plowing should be done in the fall. As early in the spring as the ground is in working order, harrow thoroughly and make as level as possible; sow thinly in drills, one-fourth inch deep and twelve inches apart. Keep the surface of the ground open, and free from weeds, but do not ridge up to the growing bulbs. One ounce will sow 100 feet of drill; 4 to 5 pounds per acre.

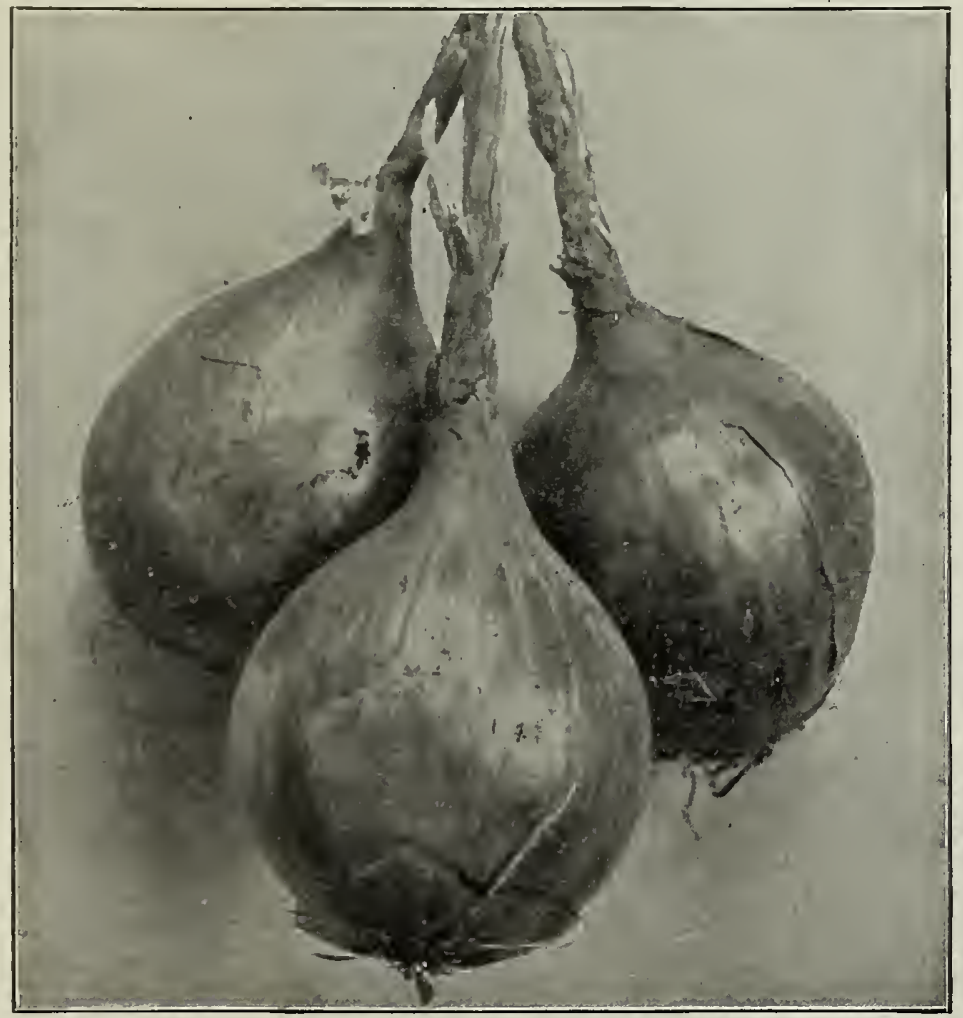

SOUTHPORT YELLOW GLOBE

\section{Southport}

Yellow Globe

A large handsome globeshaped yellow variety, ver y productive, of mild flavor. The outer skin is a beautiful pale yellow; the bulbs are good keepers, uniformly thinnecked, insuring thor ough ripening.

Pkt. 5c, oz. 20c

Yellow Danvers.-A fine, productive, flat variety of medium size; skin straw colored, the flesh white, comparatively mild, and well flavored. An excellent keeper.

Packet 5c, ounce 20c

Large Yellow Strassburg.-A good keeper, valu a ble for shipping. Pkt. 5c, oz. 20c

GIANT ROCCA.-A large globe-shaped onion. The flesh is very sweet and mild. This variety ripens evenly and does well in both northern and southern climates. We offer the yellow variety.

Packet 5c, ounce 20c

Mammoth Yellow Spanish, or PRIZETAKER

A very handsome onion of the largest size and nearly globular in form. Skin is yellowish-brown; flesh white, mild and tender. It is one of the best of the large sorts.

\section{AILSA CRAIG}

One of the largest of onions. It is a very handsome oval shaped variety with pale straw-colored skin. Is very productive, a good keeper for so large an onion, and has a mild and agreeably pungent flavor. To attain largest size it should be sown early in hotbed and later transplanted. For exhibition purposes it is unexcelled-always giving under the same conditions larger and more shapely bulbs than the Prizetaker. Market gardeners who grow this, box them and compete successfully with the imported Spanish Onion.

Packet $10 \mathrm{c}$, ounce $35 \mathrm{c}, 1 / 4$ pound $\$ 1.25$.

\section{Southport Red Globe}

Of medium size, globe shaped with small neck, very deep rich red color, and of superior quality. A large producer and good shipper.

Packet 5c, ounce 20c

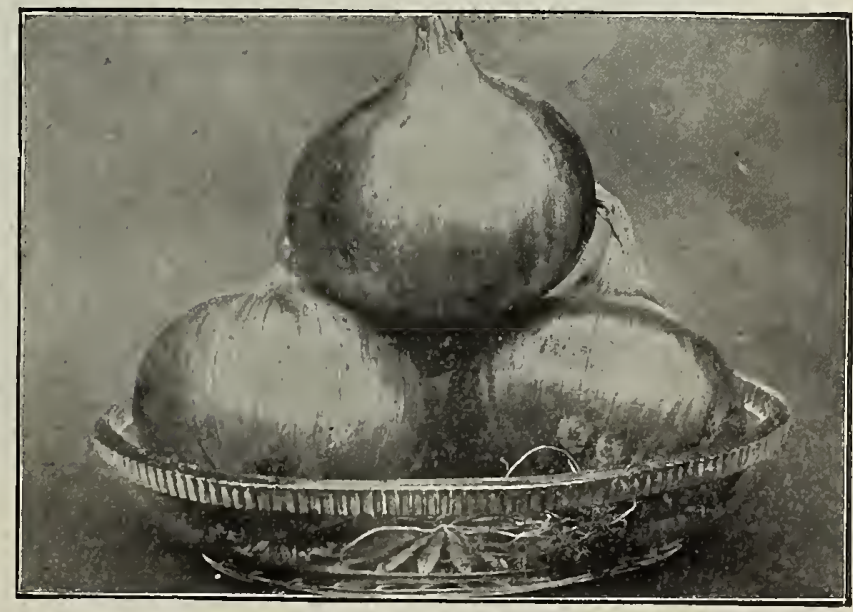

AILSA CRAIG 


\section{W. E. DALLWIG 34-Juneau Ave. MILWAUKEE}

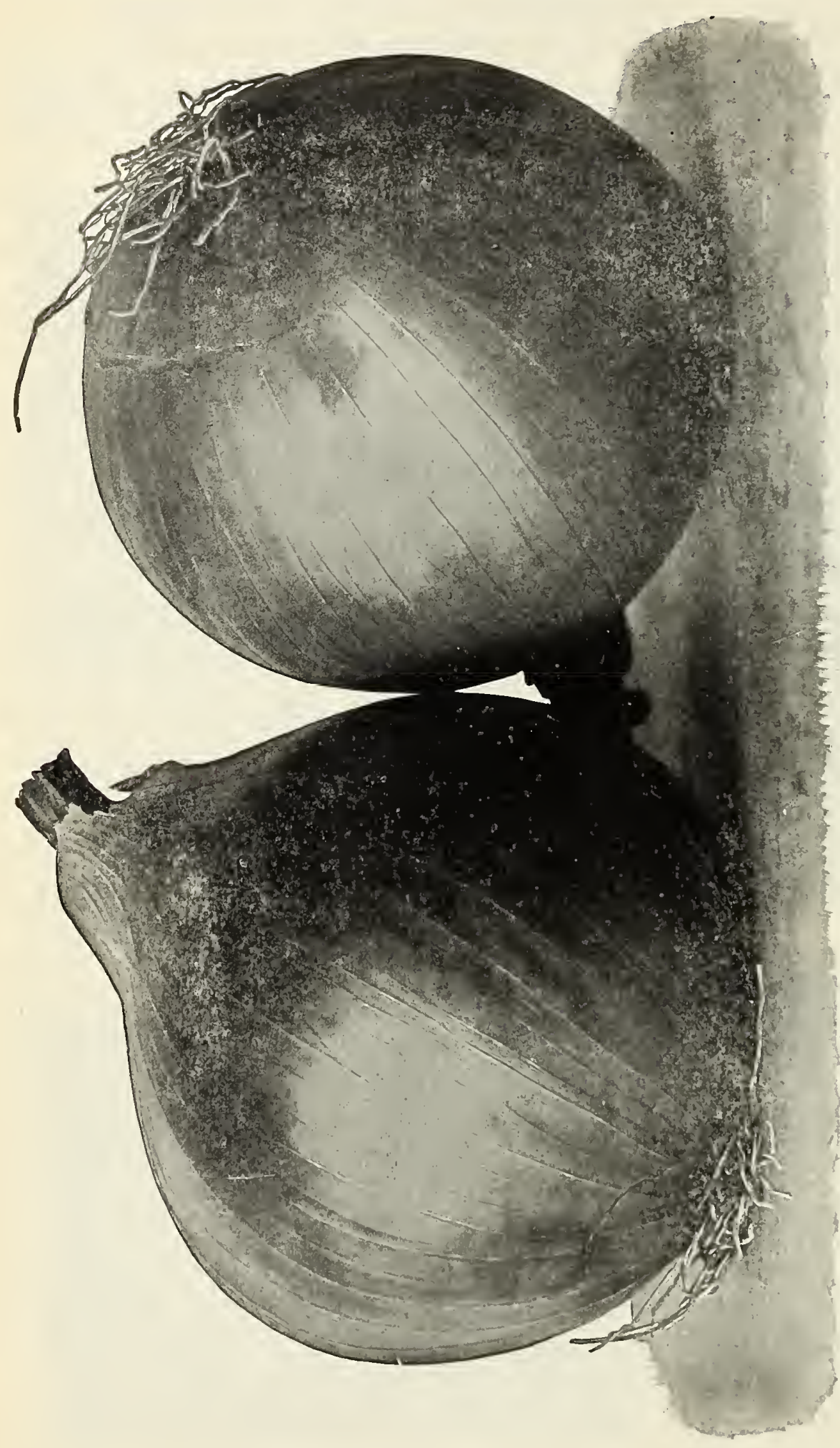

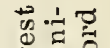

胥兽

듬

๙

\& $\underbrace{\infty}_{0 \rightarrow 0}$

sc

면

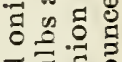

ชี

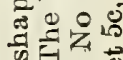

$\stackrel{\infty}{8} \dot{0}$

용

สี

$\rightarrow \rightarrow$

on

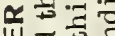

记

एठ ठक के

$\sum_{\infty} \circ$

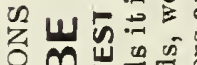

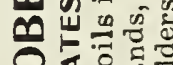

$0, \frac{0}{0} .0$

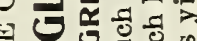

m in

过

3 검효

넝웛

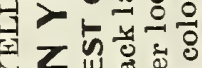

$><w$

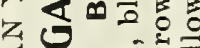

元

元这。

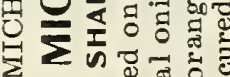

ㄴ

世

4

w क

$1>0$

놀

응

क

๙

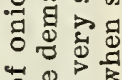

पू

讷

政

虫

sor

.

है 


\section{Order Sheet \\ W. E. Dallwig, 34 Juneau Ave. Milwaukee, Wis.}

Cash Enclosed, \$.

Date.

Your Name,

Address.

Shipping Directions or Freight. $_{\substack{\text { Mail, Exs } \\ \text { Expess }}}$

Express Office

WE GIVE NO WARRANTY, EXPRESS OR IMPLIEO, AS TO DESCRIPTION, GUALTY, PRODUCTIVENESQ, OR ANY OTHER MATTER OF ANY SEEOS, BULBS OR PLANTS WE BENO OUT, AND WE WILL NOT BE IN ANY WAY RESPONSIBLE FOR THE CROP. IF THE PURCHASER DOES NOT ACCEPT THE GOODS ON THESE TERMS, THEY ARE AT ONCE TO BE RETURNEO.

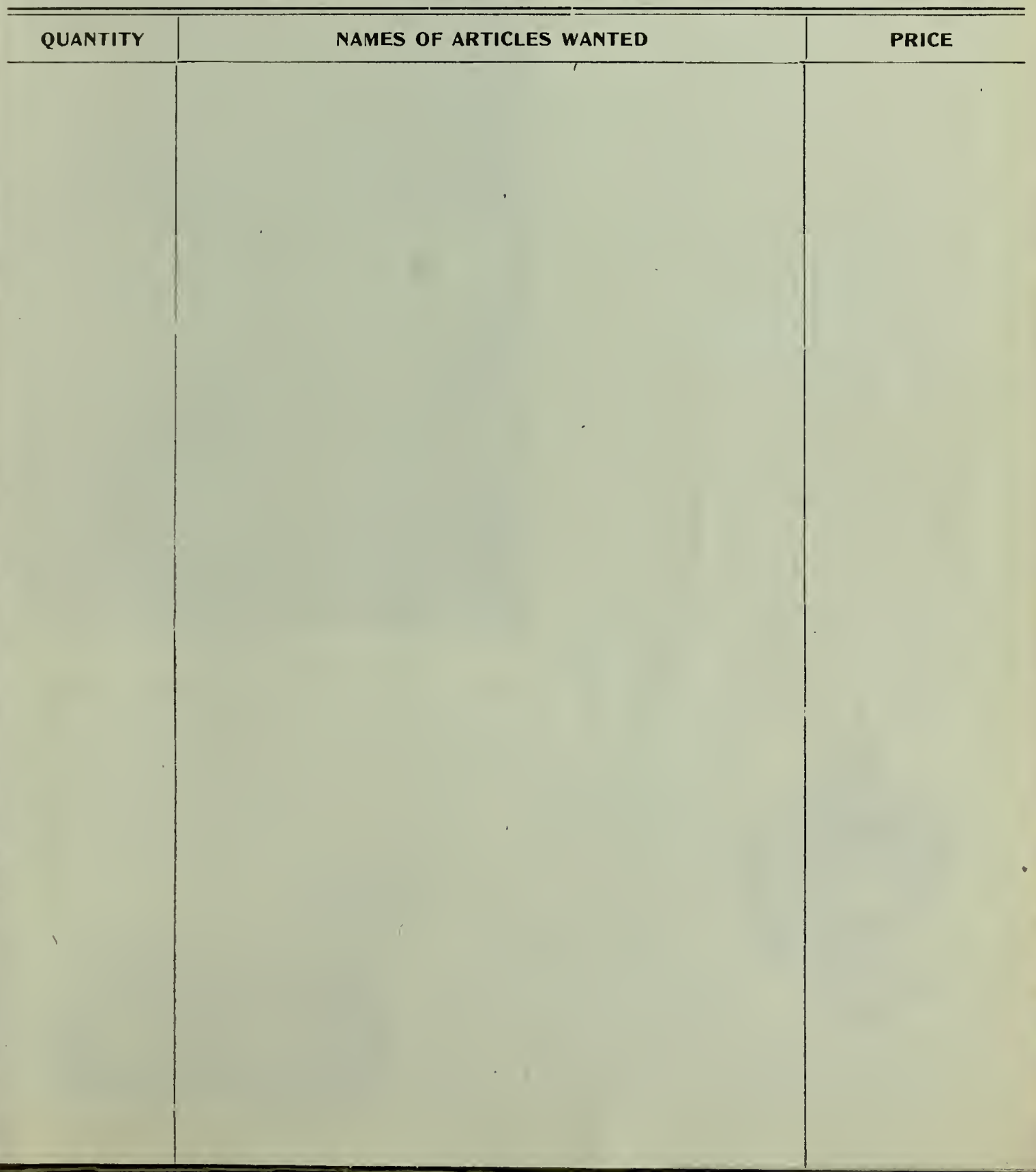




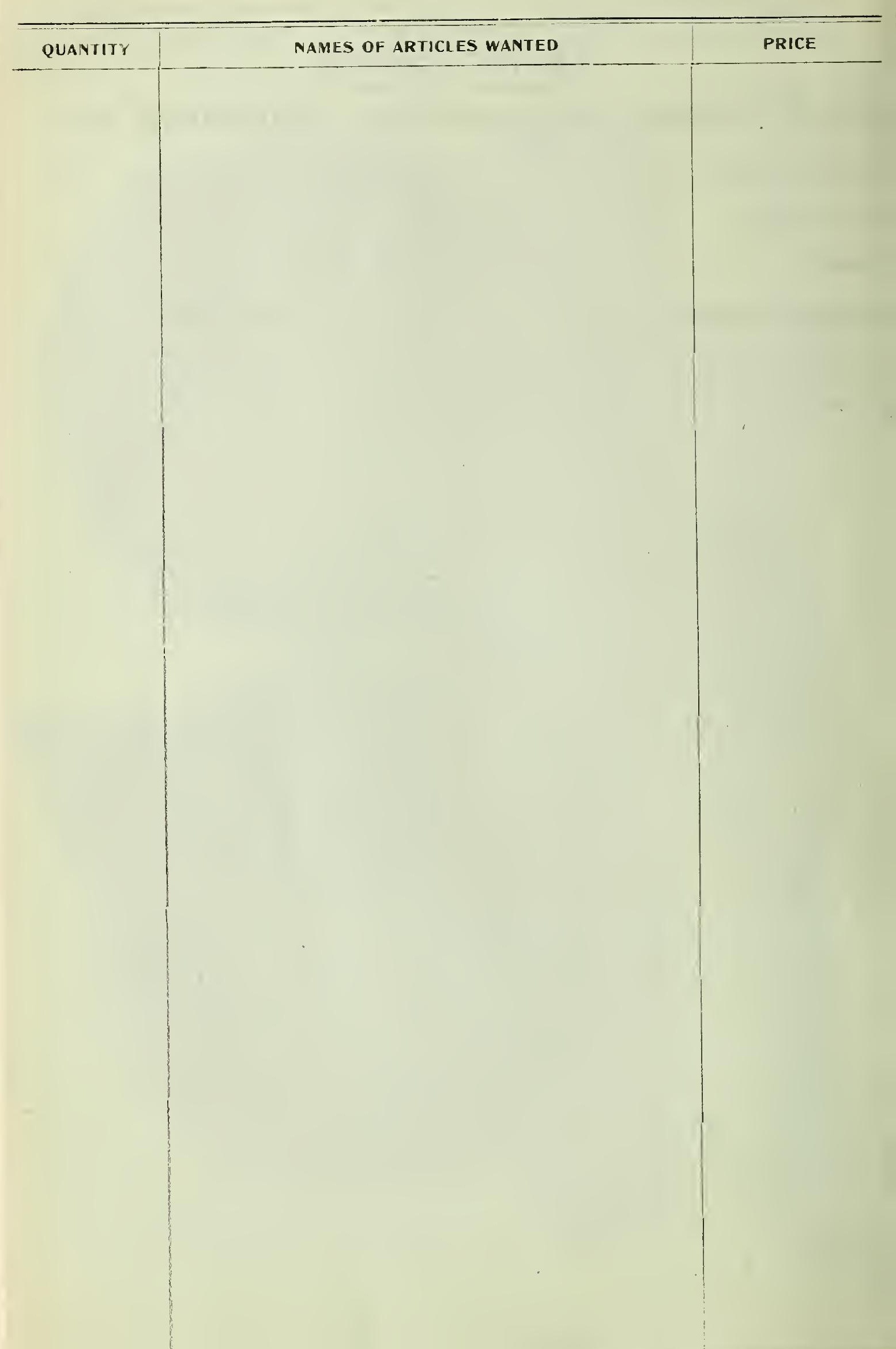




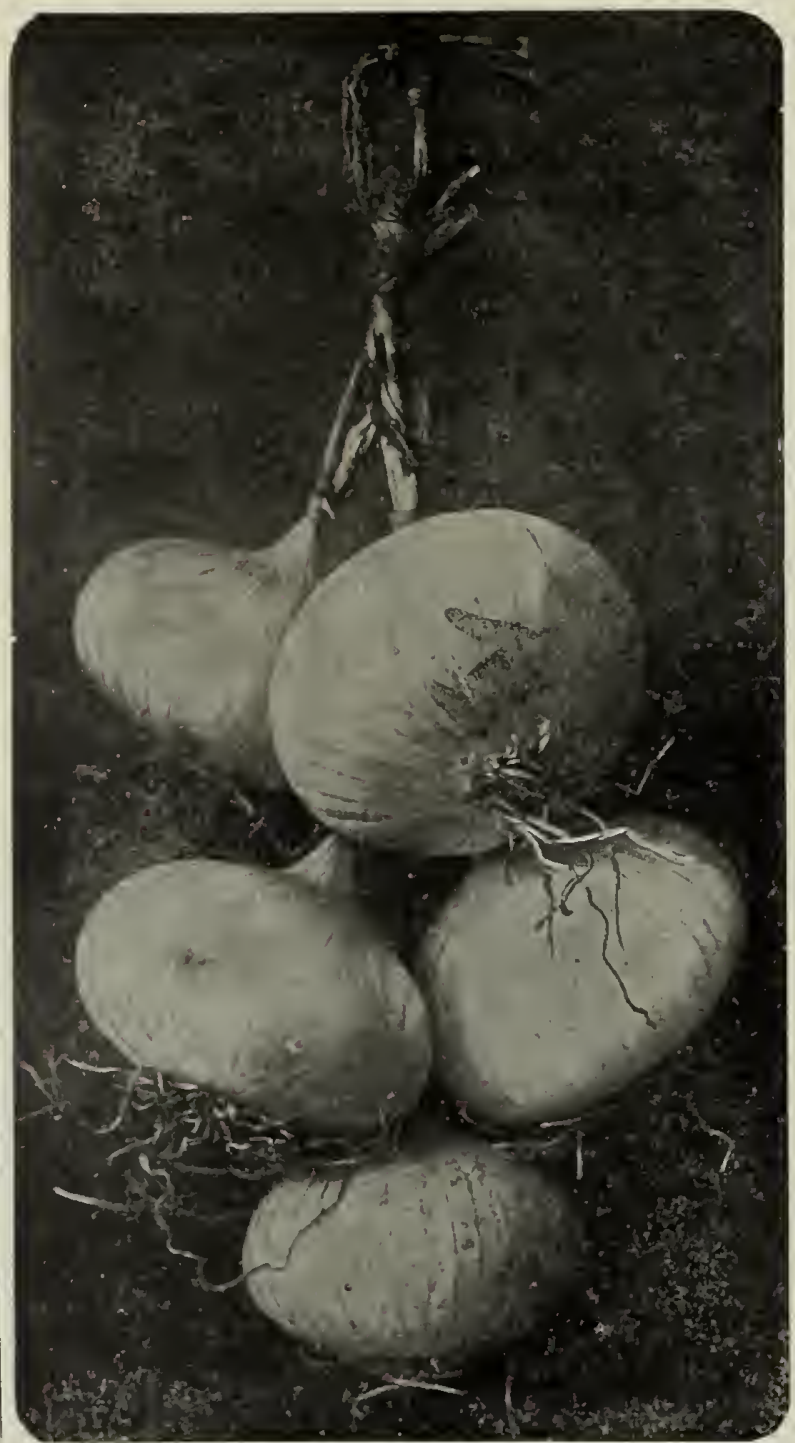

WHITE QUEEN

\section{ONION continued.}

Wethersfleld Large Red.-Large, deep red flat variety. Productive, good keeper.

Packet 5c, ounce 20c

\section{Southport White Globe.}

Yields abundantly, producing handsome and uniformly globe shaped bulbs. The flesh is firm, fine grained, of mild flavor, and as a table variety its clear white color is exceptionally attractive. Our strain has no superior in uniformity and beauty of shape and color. Pkt. 5c, ounce 25c

WHITE PORTUGAL, OR SILVER SKIN.One of the leading white sorts, of beautiful shape and very mild flavor. The bulb is flat in shape and matures early. It is a splendid variety both for family use and the market gardener, and is very largely used for sets on account of its fine shape, and also for its good keeping qualities. It is also extensively used as a pickling onion, for which purpose it seems to be finely adapted. Pkt. 5c, ounce 25c

No vegetable is harder to keep true than the Onion. Not only are there the ordinary dangers from crossing, but if all conditions are not ideal, scallions or plants without true bulbs are very likely to be formed. Moreover, good color and shape are never attained without many seasons of most painstaking selection; otherwise the shade in the case of reds and yellows is weak and pale, making the onions far less attractive. Our strains are all that the most exacting could require.

Extra Early Bloomsdale Pearl.-Earliest of all, growing with rapidity of a summer radish. Pearly white, waxy, translucent, form flat and broad Flavor very mild, indeed, it can be eaten raw almost with the freedom of an apple. On a very rich soil it will grow sometimes 5 and 6 inches across the top. Packet 5c, ounce 25c White Queen.-A rapid growing variety of mild flavor; pure white, and splendid for pickling. They grow small and can be sown thickly. It is best to dry the onions as soon as dug. Packet 5c, ounce 20c

EXCELSIOR PICKLING.-This is an early, small, round, hard variety, with an opaque, white skin. Crisp, tender, and very handsome.

Packet 5c, ounce 20c Round White SIlverskln Pickling.-Early, round variety, with opaque white skin. An excellent sort for bunching or pickling.

Packet 5c, ounce 20c EARLY WHITE WELSH.-For Green Onions. This sort does not form a bulb,

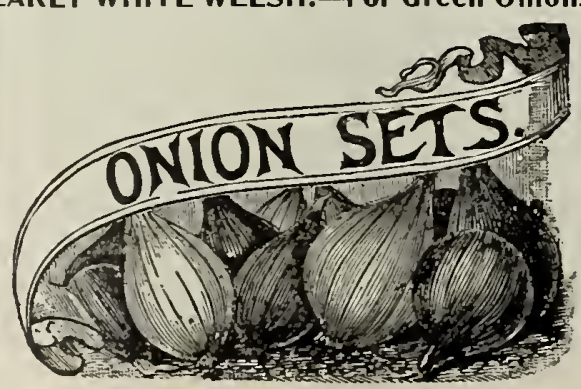
but is one of the best kinds for "Green Onions". The plants are perennial. Packet 5c, oz. 20c

\section{ONION SETS}

Onion Sets may be planted as early in the spring as the condition of the ground will permit, and they will produce onions in the green state by June. Yellow, White and Red Sets. Multlpllers. True Tops. 


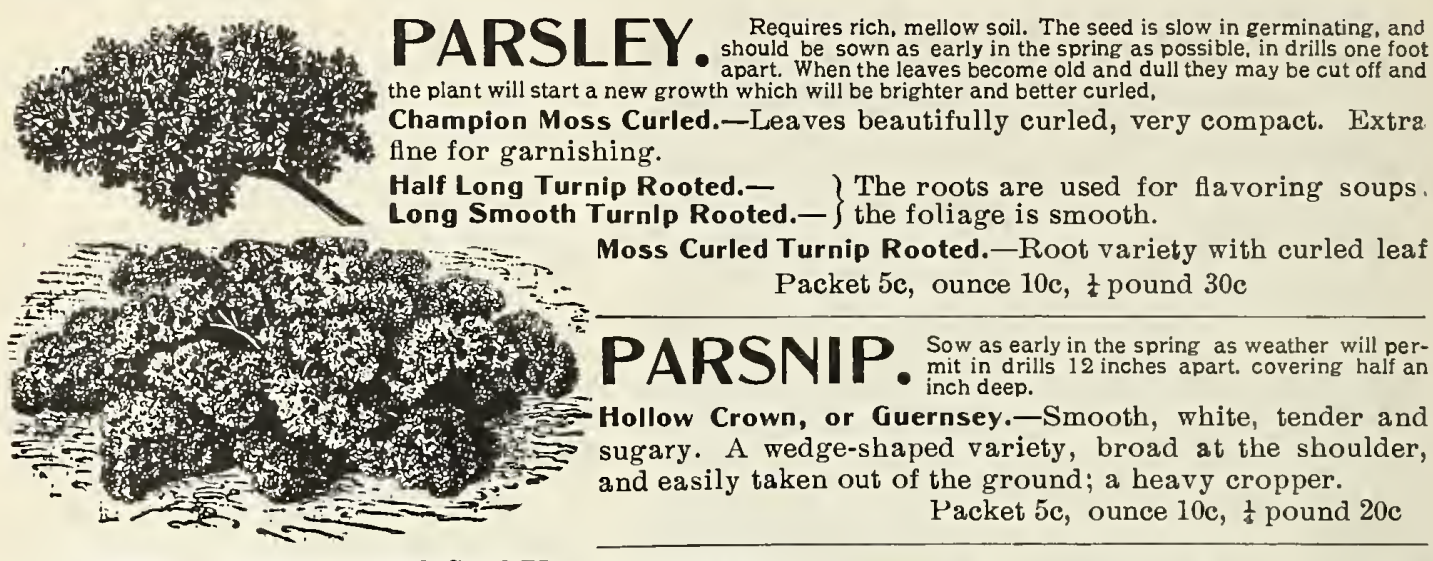

PARSLEY, CHAMPION MOSS CURLED

PEANUTS. Mammoth Virginia.-The most profitable variety to grow. Erect stems and upright foliage and the largest pods and kernels of any variety; also fewer imperfect pods.

Packet 5c, pound $10 \mathrm{c}$, pound $30 \mathrm{c}$

PEPPER. Sow in hotbeds or boxes in the house, and set out about the last of May, in

Long Red Cayenne.-Fruit long, slender, bright red, very hot and pungent; productive.

Large Beli, or Bull Nose.-The fruits are large, with thick, mild flesh of excellent quality for use in salads or stuffed peppers. Deep green when young, bright crimson when ripe.

Ruby King.-One of the most popular; a bright ruby red, and one of the best sorts for stuffed pickles.

ABOVE VARIETIES: Packet $5 \mathrm{c}$, ounce $20 \mathrm{c}$, $\frac{1}{d}$ pound $60 \mathrm{c}$ Upright Sweet Salad.-Early, and so mild that even the seed may be eaten raw; of medium size, just right for stuffing and frying. Of medium height, and bears the peppers upright instead of drooping, making the gathering very easy. Color is a bright shiny green, which turns to a waxen red when ripe.

Packet 5c, ounce $35 \mathrm{c}$, 1 pound $\$ 1.25$
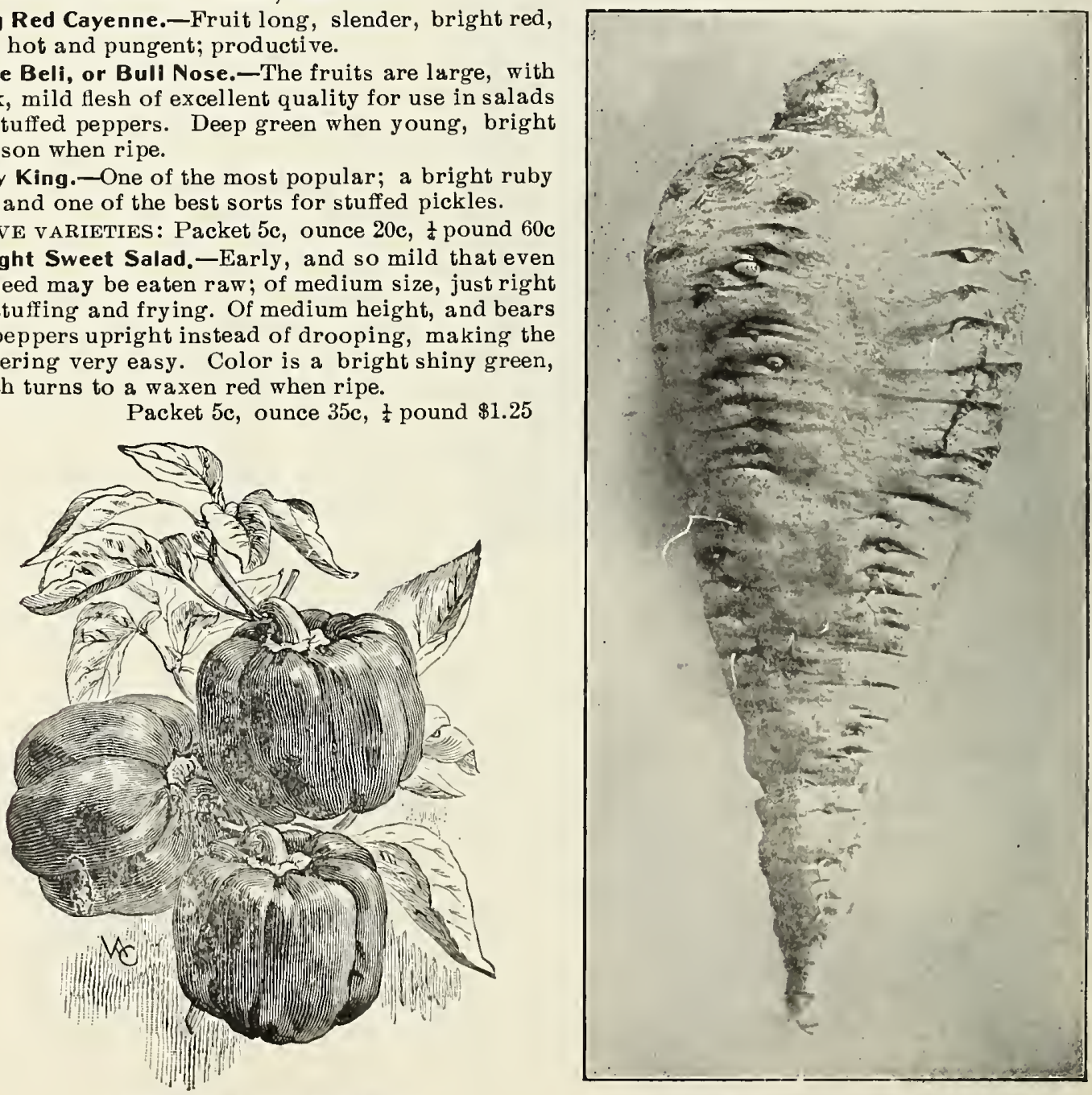
Peas mature earliest in light rich ground; for the main crop a moderately heavy soil is best. Commence sowing the early sorts as soon as the ground can be worked, and continue for a succession every two weeks until August.

Prices do not include postage; if to go by mail add at rate of $15 \mathrm{c}$ per quart. All Peas 5c per Packet.

Landreth's Extra Farly. -Everywhere the standard for earliness, maturing for table fortyLandreth's Extra Earlys from germination and frequently, under peculiar conditions, in thirty-eight days. Vines 2 feet high, sticks not necessary. May be planted in August and still produce a crop.

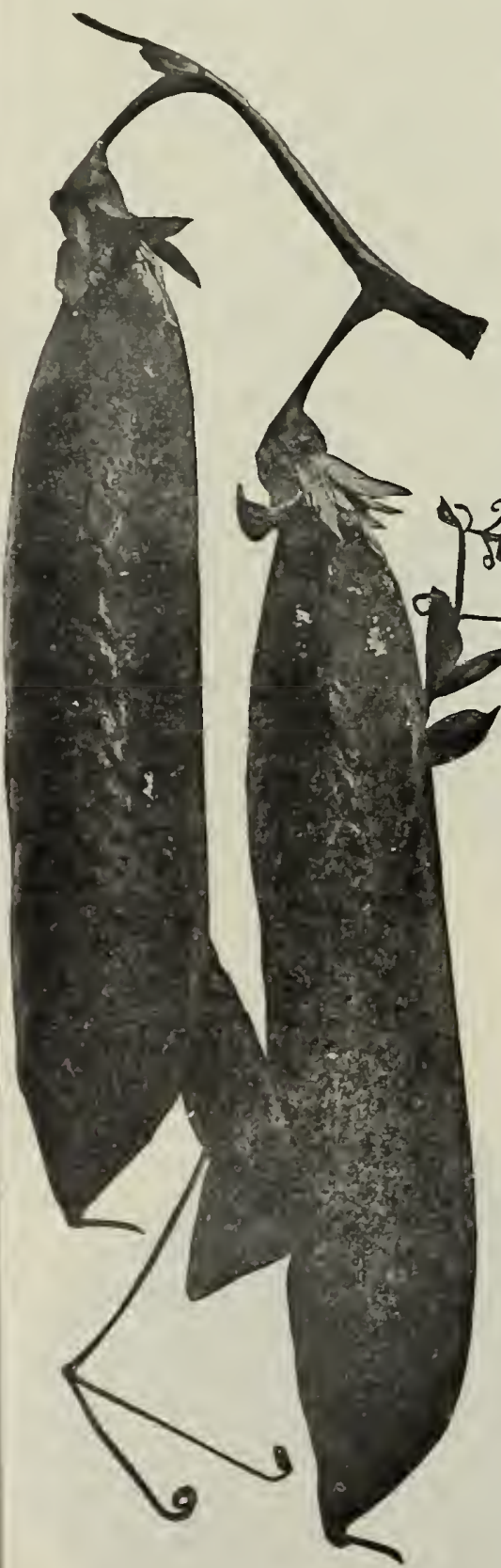

GRADUS

$\frac{1}{2}$ Pint $10 \mathrm{c}$, pint $20 \mathrm{c}$, quart $40 \mathrm{c}$

Extra Early Market.-The earliest and most even stock of white extra early peas, maturing so well together that sometimes a single picking will secure the entire crop. Vines vigorous and hardy, extremely prolific, the pods being numerous, and well filled with peas of good size and fair quality.

$\frac{1}{2}$ Pint $10 \mathrm{c}$, pint $20 \mathrm{c}$, quart $40 \mathrm{c}$

Alaska.-Grows about two feet high and bears pods well filled with medium-sized, bright green peas of good flavor.

$\frac{1}{2}$ Pint $10 \mathrm{c}$, pint $20 \mathrm{c}$, quart $40 \mathrm{c}$

Thomas Laxton.-Of darker color and more hardy than the Gradus, which it resembles. Notwithstanding its earliness, the pods are fully as large as those of Telephone, and well filled with large luscious peas. Height about 3 feet.

$\frac{1}{2}$ Pint $15 \mathrm{c}$, pint $30 \mathrm{c}$, quart $60 \mathrm{c}$

GRADUS.-An Extra Early Wrinkled Pea. The immense pods are as large as those of the Telephone, uniformly well shaped and handsome, and more attractive than those of other first earlies. They ripen slowly and continue fit for use much longer than most varieties. The peas are large, of splendid quality and beautiful color which they retain after cooking.

$\frac{1}{2}$ Pint $15 \mathrm{c}$, pint $30 \mathrm{c}$, quart $60 \mathrm{c}$

AMERICAN WONDER.-The earliest of the dwarf, wrinkled varieties. About nine inches high and covered with well filled pods of medium size, containing five to eight large, exceedingly sweet, tender and well flavored peas.

Pint 20c, quart $40 \mathrm{c}$

Nott's Excelsior.-This is a very fine extra early dwarf Wrinkled pea. The pods a verage fully Bcst Early Dwarf Pea. one-thild larger than those of American Wonder, though not quite so early by a few days. The peas are of unusually sweet, flavor, and so closely are they packed in the pods that they are flattened against each other. A most desirable sort for market gardeners, and unsurpassed for the home garden. Pint 20, quart $40 \mathrm{c}$ Premium Gem.-An improvement upon the Little Gem, larger and more productive.

Pint 20c, quart $40 \mathrm{c}$

Improved Telephone or Alderman.-Vine vigorous, growing about four feet high, with large coarse leaves The pods are of immense size, a fine dark green color, much more desirable than the light green of the ordinary Telephone and the peas are tender and deliciously sweet. Market gardeners are demanding the large podded, dark colored sorts which retain their fine appearance even after shipping a long distance. The Alderman answers these requirements and furthermore is the most productive variety of this class. We recommend it unreservedly.

Pint $25 \mathrm{c}$, quart $50 \mathrm{c}$

\section{SUGAR PEAS WITH EDIBLE PODS}

Improved Early Giant Sword Pole.-The vines grow from four to five feet high. Very productive, with enormous pods which a verage 6 inches in length and $1 \frac{1}{2}$ inches broad. Thick, fleshy, tender and sweet. Broken and boiled like string beans, and served with butter sauce, they have a luscious flavor.

$\frac{1}{3}$ Pint $15 \mathrm{c}$, pint $30 \mathrm{c}$, quart $60 \mathrm{c}$

Fuerst Bismarck.-Dwarf variety, $1 \frac{1}{1}$ feet high, of large size, and excellent quality. Price as above.

NOTE:-If Peas are wanted by mall, add $4 \mathrm{c}$ per half pint, $8 \mathrm{c}$ per pint, $15 \mathrm{c}$ per quart. 


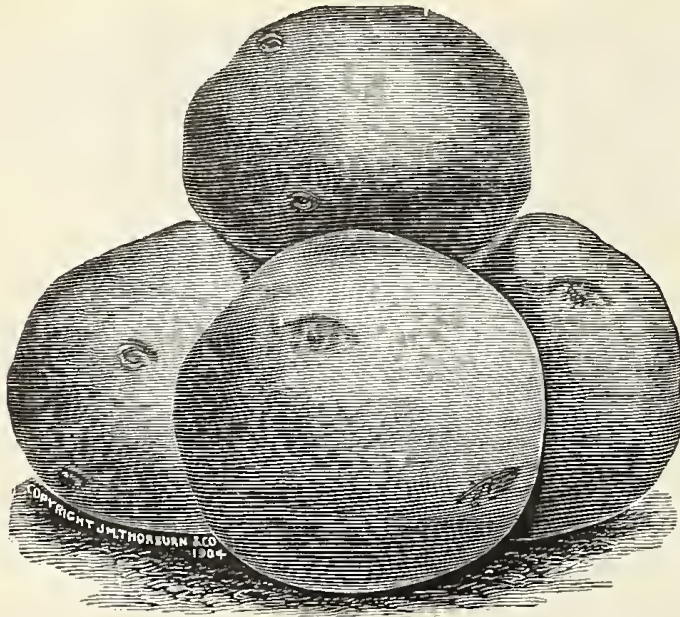

NOROTON BEAUTY
P OTATOES

-One peck will plant about 125 hills-

Our seed potatoes are "Northern Grown" by expert cultivators, and have been selected for quality with the greatest care. Our revised list contains the cream only. Inferior sorts are eliminated. The tubers are large and free from disease. Prices on Application.

White Ohio.-Identical in every way to the best type of old Ohio, except in color, which is a fine white. It has given the best of satisfaction in the past. For every locality where a White Potato is the popular market color this new Ohio is bound to be a winner.

\section{NOROTON BEAUTY}

The Most Valuable Potato Ever Introduced

The earliest potato ever grown, being 16 days earlier than the Early Rose. Yet fully as productive as any main-crop or late sort. This combination of extreme earliness, productiveness and keeping qualities has never before been attained. It is handsome in appearance and more uniform in size and shape than any other variety. The tubers

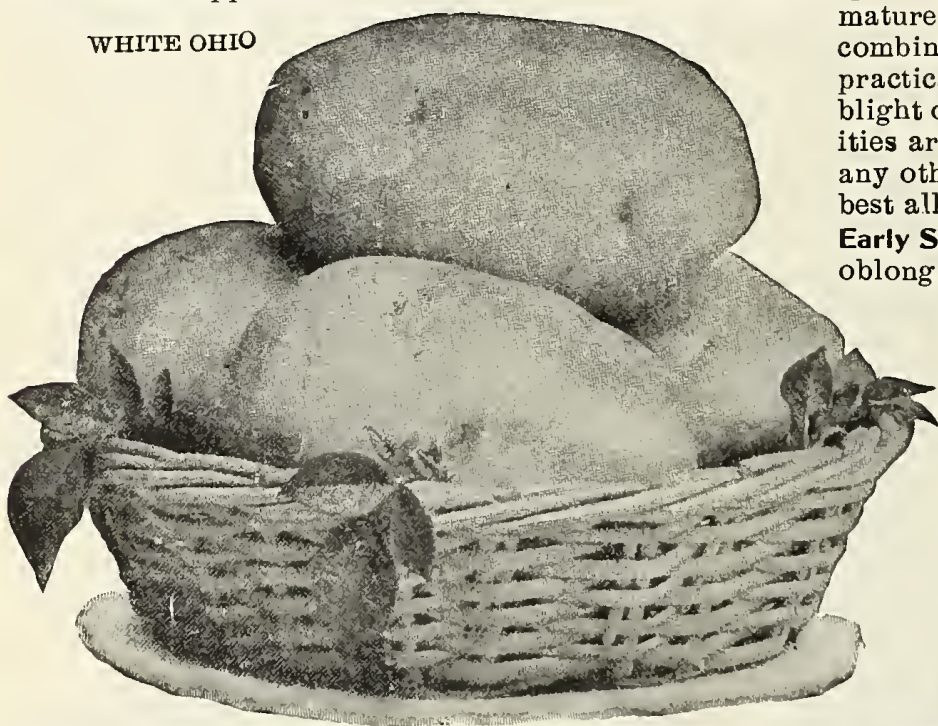
mature simulíaneously, a fact which, with its extreme earliness, ly does away with danger from blight or disease or bugs. Its table qualare superb, and it keeps longer than t all-around potato in existence.

Six Weeks.-Medium size, smooth blong, skin pink, flesh white, tubers grow close together in the hill, and grow so rapidly that under favorable circumstances they are fit for family use in 6 weeks from the time of planting; mature in ten or eleven weeks.

Improved Extra Early Ohio.-A special favorite with marketmen and the most profitable sort they can grow. In this improved type the tubers are $\mathrm{much}$ smoother and of better shape than the well known Early Ohio, while the yielding qualities are improved

one third. They keep firm until late in spring.

Early Rose.-We claim for our stock of this well-known variety extra earliness and better yielding qualities than found in the a verage stock.

Sir Walter Raleigh.-Very productive late variety; white flesh of best quality.

Rural New Yorker No. 2.-Very few and shallow eyes; pure white flesh; immense yielder; fine quality; late.

\section{PUMPKIN}

Mammoth Tours. - A French variety of immense size. Pkt. 5c, oz. 10c Sugar.-Small, round Pumpkin, with deep orange-colored skin, flesh sweet and sugary. Pkt. 5c, oz. 10c Common Field.-Used for c attle feeding; very productive sort.

$\frac{1}{6}$ pound $10 \mathrm{c}$, pound $25 \mathrm{c}$

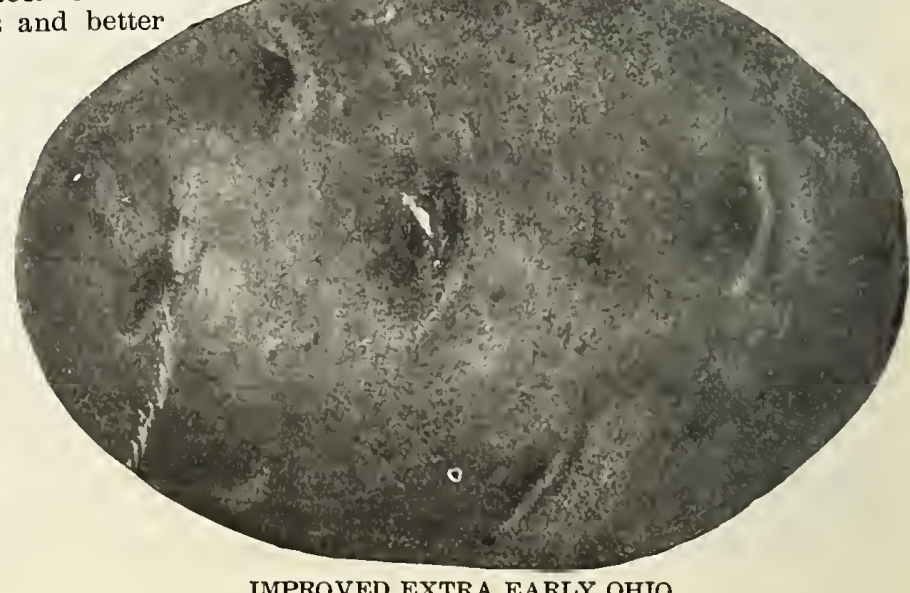

IMPROVED EXTRA EARLY OHIO 
For the first crop sow as early in the spring as the ground can be worked, and every two weeks for a succession. A warm, sandy loam will be most likely to afford them brittle and free from maggots. Sow in drills 10 to 12 inches apart. The winter varieties should be sown in July.

\section{Early Scarlet Globe}

\section{Selected Stock}

A small, round, turnip-shaped red radish, with a small top, and of very rapid growth. It is mild, crisp, juicy and tender. Bright scarlet color. Desirable both for forcing and outdoor planting. For home use should be sown every ten days or two weeks, in order always to have a fresh supply. Our stock of this important variety is the very best; selected with special care as to size, shape, color and earliness. Pkt. 5c, oz. 10c, $\frac{1}{4} \mathrm{lb} .25 \mathrm{c}, 1 \mathrm{~b}$. $65 \mathrm{c}$

\section{Dallwig's “20 Day"}

\section{Excellent for Forcing}

Quick growth is one of the main essentials for a cris $p$ and tender radish. This variety matures very rapidly, making it valuable both for forcing and for outdoor culture. The flesh is pure white, ver y crisp and of pleasant flavor; the skin is a most attractive bright searlet. Very short-leaved. Form slightly elongated or cono shaped.

Packet 5c, ounce $10 \mathrm{c}$, $\frac{1}{4}$ pound $25 \mathrm{c}$, pound $75 \mathrm{c}$

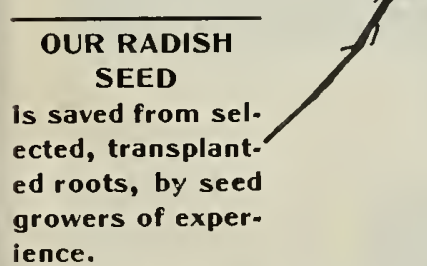

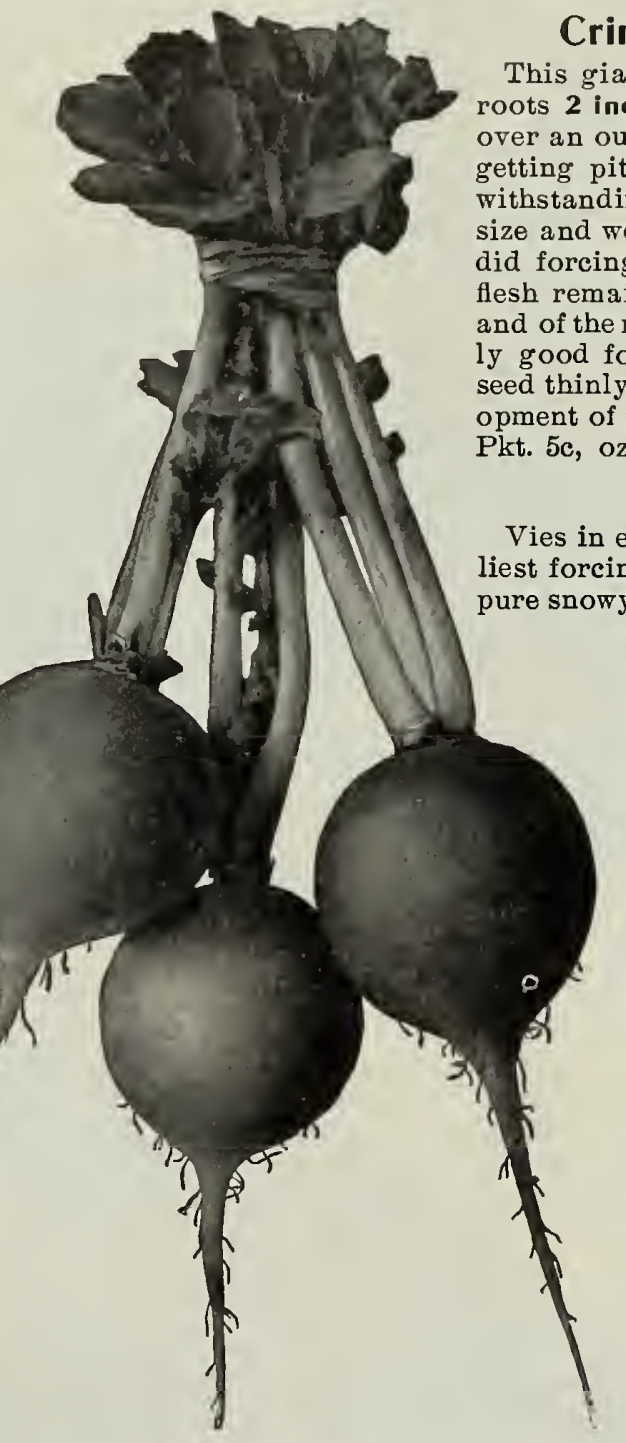

\section{Crimson Giant}

This giant radish develops roots 2 inches in diameter and an ounce in weight, without d hot anding its extraordinary forcing sort, its pure white remaining firm and crisp, ly good for outdoors. Sow the seed thinly, to permit full development of the roots.

$10 \mathrm{c}, \frac{1}{11 \mathrm{~b} .} 25 \mathrm{c}, 1 \mathrm{~b} .75 \mathrm{c}$

\section{Icicle}

Vies in earliness with the eariest forcing radishes Roots of $y$, almost transparent whiteness, four inches in length and half an inch in diameter; they retain their crispness and fresh, mild flavor a long time. They are slenderly tapering, with but very few small leaves.

Packet 5c, ounce 10c t pound 20c, pound $60 \mathrm{c}$

\section{DALLWIG'S OVAL SHAPED GOLDEN YELLOW}

Skin rich golden yellow; fle sh white, very crisp and tender. The roots are oval, smooth and handsome.

Packet 5c, ounce 10c $\frac{1}{4}$ pound $25 \mathrm{c}$, pound, $65 \mathrm{c}$

Scarlet Turnip, White Tlpped.-Early deep scarlet with white tip ; round. Packet 5c, ounce 10c, $1 / 4$ pound 20c.

French Breakfast.-Olive shaped; scarlet with white tip. Showy and delicate. Packet $5 \mathrm{c}$, ounce $10 \mathrm{c}, 1 / 4$ pound $20 \mathrm{c}$.

Earliest White Turnip. - Short top. Small, delicate, white bulbs; fine for forcing.

Packet 5c, ounce $10 \mathrm{c}, 1 / 4$ pound $20 \mathrm{c}$.

Long Scarlet Short Top.-

Long, straight, smooth, rich scarlet, a quick grower.

Pkt. 5c, oz. 10c, 1/4 lb. 20c.

Giant White Stutigart. -

Very large, heart shaped, white radish of quick grow th

Pkt. 5c, 0z. $10 \mathrm{c}, 1 / 4$ ib. $20 \mathrm{c}$.

Delicacy.-Very early, snow white, tender. Fine for forcing or open ground.

Pkt. 5c, oz. 10c, 1/4 lb. $20 \mathrm{c}$.

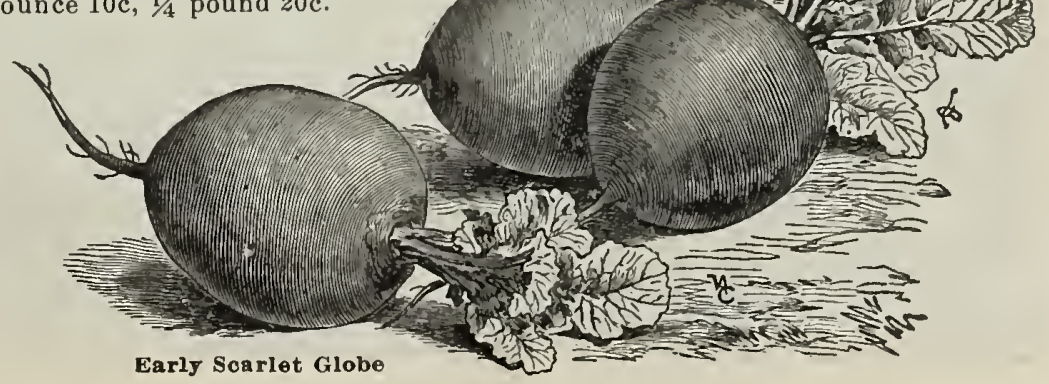




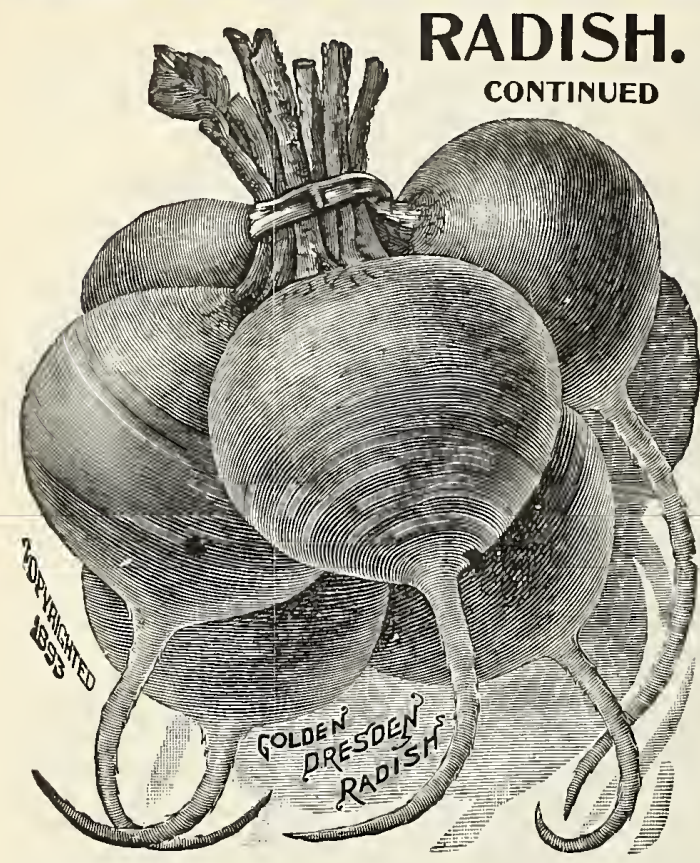

White Strassburg. The roots are of handsome oblong, tapering shape; both skin and flesh are pure white. The flesh is firm, brittle and tender, and possesses the most desirable characteristic of retaining its crispness for a long time. It is excellent for summer use, as it withstands severe heat and grows very quickly. The seed can be planted throughout the summer, and fine large roots will be rapidly formed. Valuable for home use and for the market gardener. Packet 5c, ounce10c, $\frac{1}{4}$ pound $20 \mathrm{c}$, pound $50 \mathrm{c}$

White Munich. The excellence of this radish is found in the quite pronounced but nevertheless agreeable pungeney of its flavor. It is very erisp and tender, and has an extremely smooth and fine grained skin with no tendency to throw out side roots. Its form is a tapering oval, and it grows to a very large size. It is suitable for forcing and outdoor cultiva. tion. Packet $5 \mathrm{c}$, ounce $10 \mathrm{c}, 1 / 4$ pound $25 \mathrm{c}$, pound $75 \mathrm{c}$.

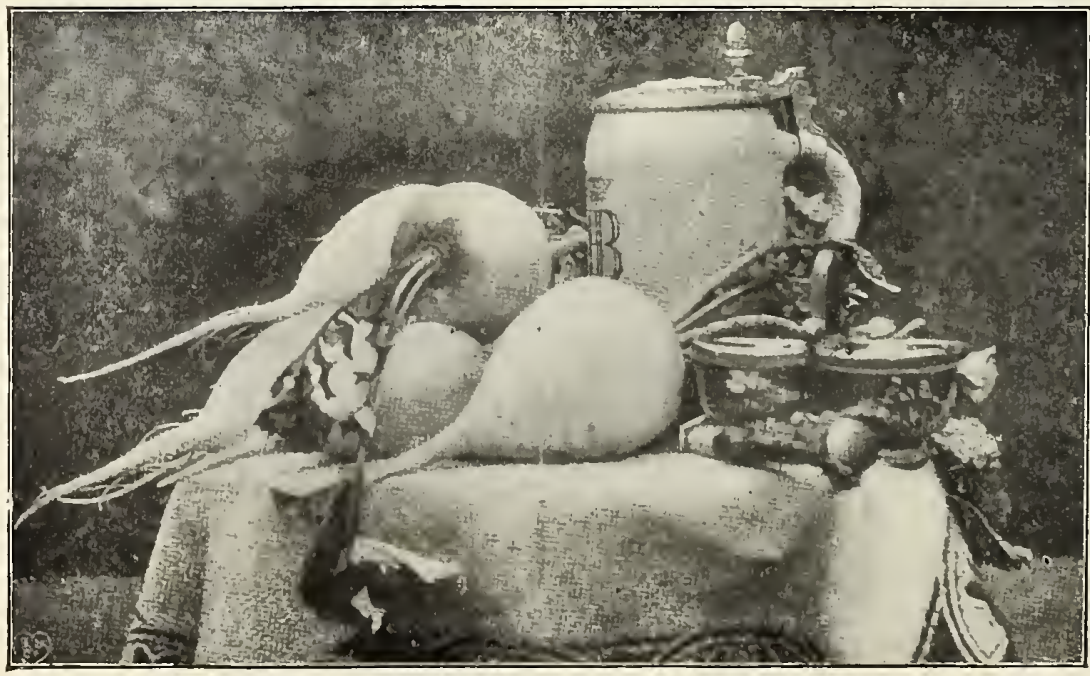

Golden Dresden. A valuable sort both for market and family use. It is of quick growth making radishes in twenty-eight days from germination. The roots are of medium size, round, smooth and have a clear golden skin. The flesh is white and of fine flavor.

Packet 5c, ounce $10 \mathrm{c}$, 表 pound $20 \mathrm{c}$, pound $60 \mathrm{c}$ Early Oval Shaped White Forcing. - A white radish very similar to our Oval Shaped Golden Yellow; equally valuable for forcing or open-air culture; crisp and tender flesh, and handsome shape.

Packet 5c, ounce $10 \mathrm{c}$, pound $25 \mathrm{c}$, pound $75 \mathrm{c}$

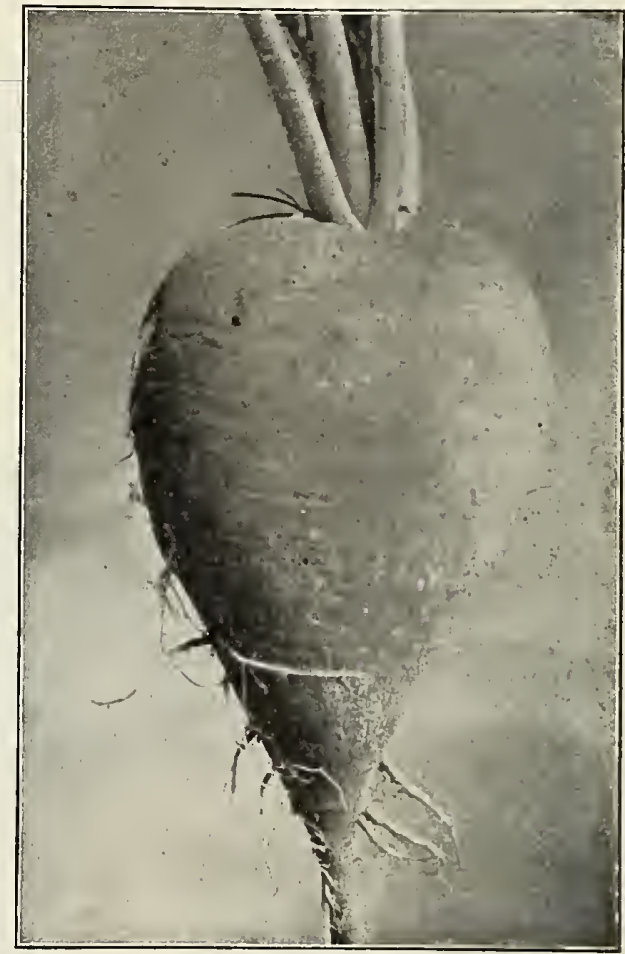

OVAL SHAPED GRAY SUMMER NO, 2

\section{Oval Shaped Gray Summer}

No. 2.- This variety is in every respect equal to our No. 1. It is somewhat later, lighter in color, and grows to a larger size. Like No. 1, it may be grown under glass as readily as outdoors, and is a valuable succession to the former. The skin is sinooth, the flesh crisp, tender, and of the finest flavor. Packet 5c, ounce $15 \mathrm{c}, 1 / 4 \mathrm{Hb}$., $40 \mathrm{c}$. 
Oval Shaped Gray-Black Summer No. 1. Smooth, solid, crisp and tender, never grows pithy. Equally fine for forcing or open air culture. A handsome radish of oval shape, and graylsh-black color; on some soils the color is black, which is lightened, however, by the irregular white lines appearing at intervals. Unlike most large radishes this variety may be forced under glass, never losing any of its delightful flavor and crispness. Grown in the open, it matures about the same time as our Oval Shaped Golden Yellow.

Packet $5 \mathrm{c}$, ounce $15 \mathrm{c}, 1 / 4$ pound $40 \mathrm{c}$.

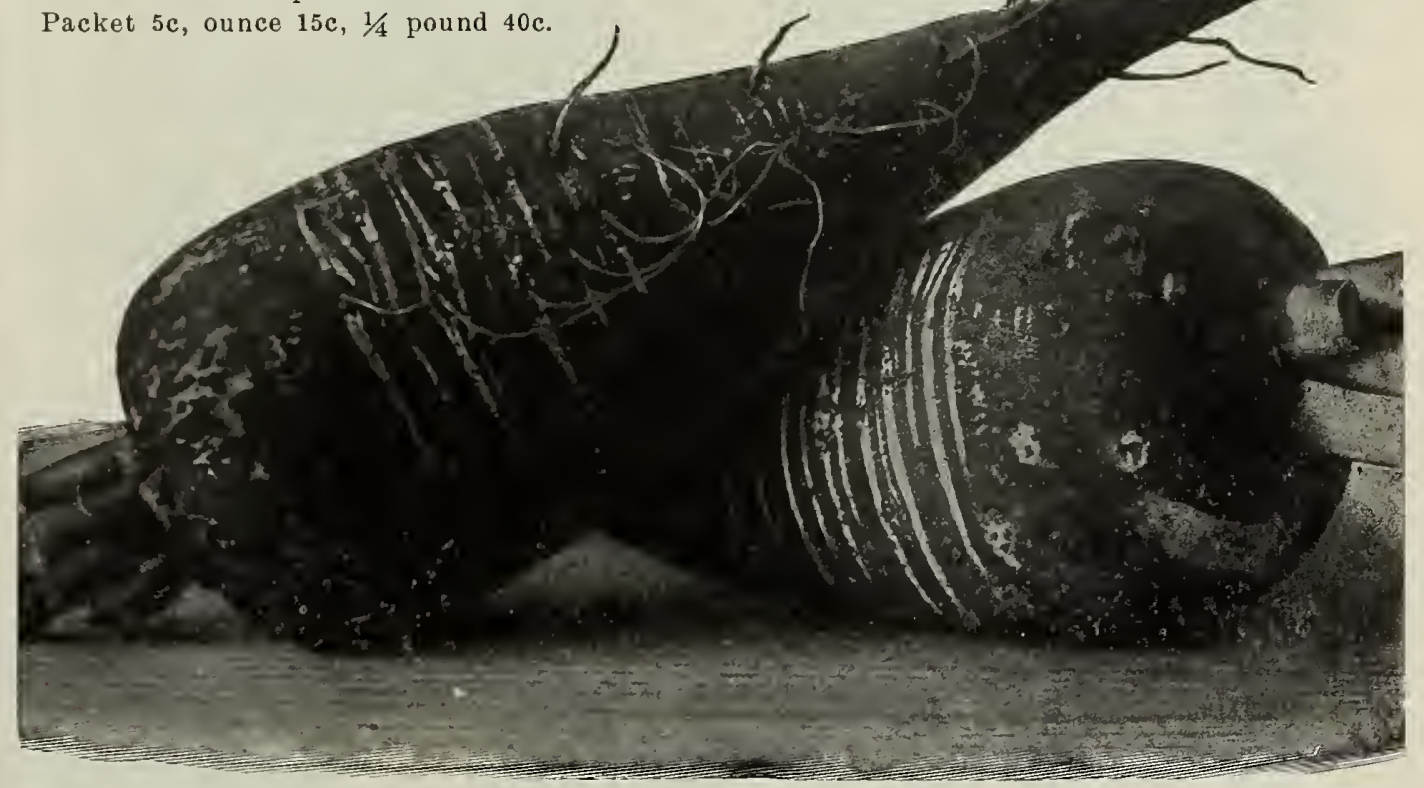

RADISH, Oval Shaped Gray-Black Summer, No. 1

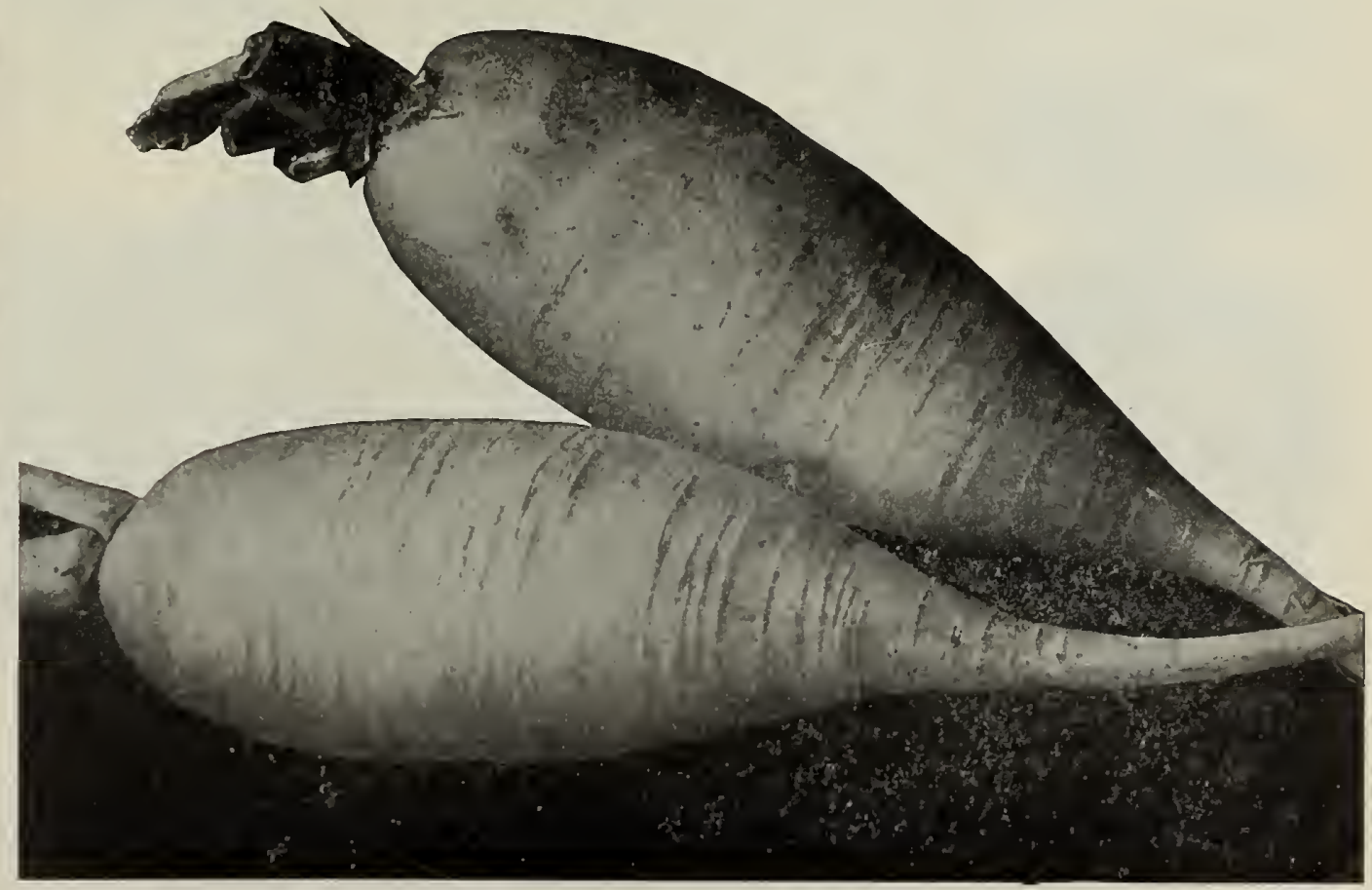



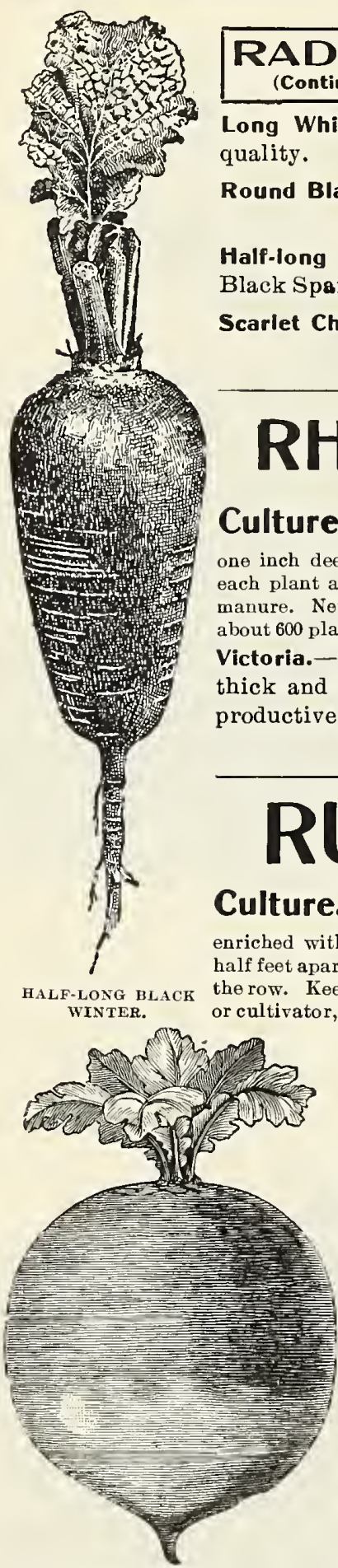

RUTABAGA. quality. about 600 plants.
RADISH.

(Continued.)

\section{WINTER RADISH.}

firm texture.

long, black, of very large size and

Per packøt $5 \mathrm{c}$, ounce $10 \mathrm{c}, \frac{1}{1 b}$. $20 \mathrm{c}$

Long White Spanish. - Valuable for winter use, of remarkably fine $C_{k e e p i n g}$

Per packet $5 \mathrm{c}$, ounce $10 \mathrm{c}$, 考 $1 \mathrm{~b} .20 \mathrm{c}$

Round Black Spanish.-A turnip-shaped, black-skinned winter-keeping Radish.

Per packet 5c, ounce $10 \mathrm{c}, \frac{1}{4} 1 \mathrm{~b} .20 \mathrm{c}$

Half-long Black Winter.-Intermediate in shape between the Round and Long Black Spanish.

Per packet $5 \mathrm{c}$, ounce $10 \mathrm{c}, \frac{1}{4} 1 \mathrm{~b} .20 \mathrm{c}$

Scarlet China Winter.-Scarlet and pink in color, tipped white.

Per packet $5 \mathrm{c}$, ounce $10 \mathrm{c}$, $\frac{1}{4} 1 \mathrm{~b} .20 \mathrm{c}$

\section{RHUBARB OR PIE PLANT.}

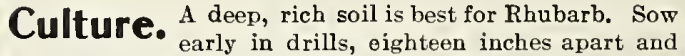
one inch deep; the spring following transplant, allowing each plant at least two feet square; each fall mulch with manure. Never allow to run to seed. One ounce makes

Victoria.-Leaf stalks very tall and large. Skin thick and red-stained. Pulp quite acid. Very productive and profitable for market gardeners.

Per packet 5c, ounce 15c, $\frac{1}{4} \mathrm{lb} .40 \mathrm{c}$

\section{RUTABAGA.}

Culture. Sow the seed about a month earlier than half feet apart, and thinned to six to eight inches apart in the row. Keep the weeds thoroughly in check with the hoe or cultivator, and when the roots have grown full size,

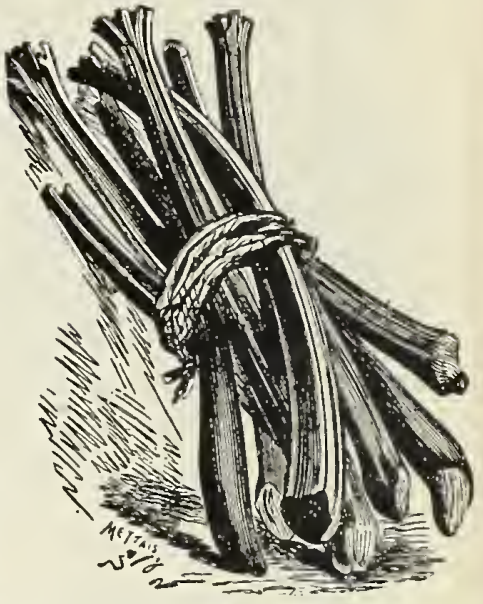

VICTORIA RHUBARB. and before hard freezing weather, pull, cut off the tops and store in a root cellar or pit. Ruta Bagas are sometimes sown broadcast and let take their chances with the weeds and bugs, but this method is only successful on new clearing in which there is no weed seed.

The Bloomsdale Swede.-In foliage it is not superabundant (as is European Swede); the shape is nearly globular and without neck, the crown deep purple, the flesh is very rich yellow.

Per packet 5c, ounce 10c, $\frac{1}{1} 1 \mathrm{~b} .20 \mathrm{c}$

SORREL.-Sorrel is cultivated for its leaves, which possess a very fine flavor; boiled and served like spinach. It also makes a delicious soup. Packet 5c, ounce 15c, t pound 35c

\section{SALSIFI OR OYSTER PLANT.}

Culture. Sow when the cherry is in bloom, in drills, in Crills should beeply dug and well manured ground. The drill a few inches weed and thin them so as to stand forr or five ar or Beets.

Sandwich Island.-A variety superior to the French sort producing smoother, larger, and more vigorous roots.

Per packet 5c, ounce $15 \mathrm{c}, \frac{1}{4} \mathrm{lb} .30 \mathrm{c}$

Imported Scorzonera or Black Salsifi.-With the same culture three times the quantity can be grown on same area as Salsifi. It should be better known. The skin only is black.

Per packet $6 \mathrm{c}$, ounce $30 \mathrm{c}$

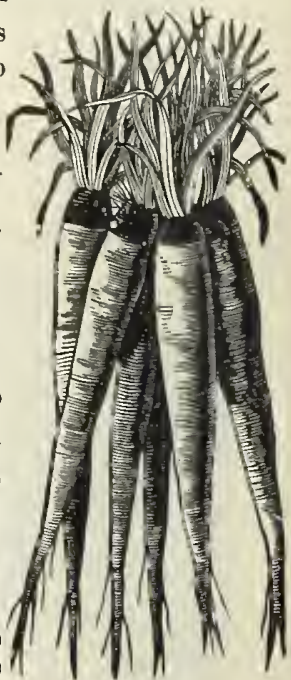




W. E. DALLWIG 34-Juneau Ave. MILWAUKEE है,

SPINACH.

ties. Especially recommended for autumn sowing.

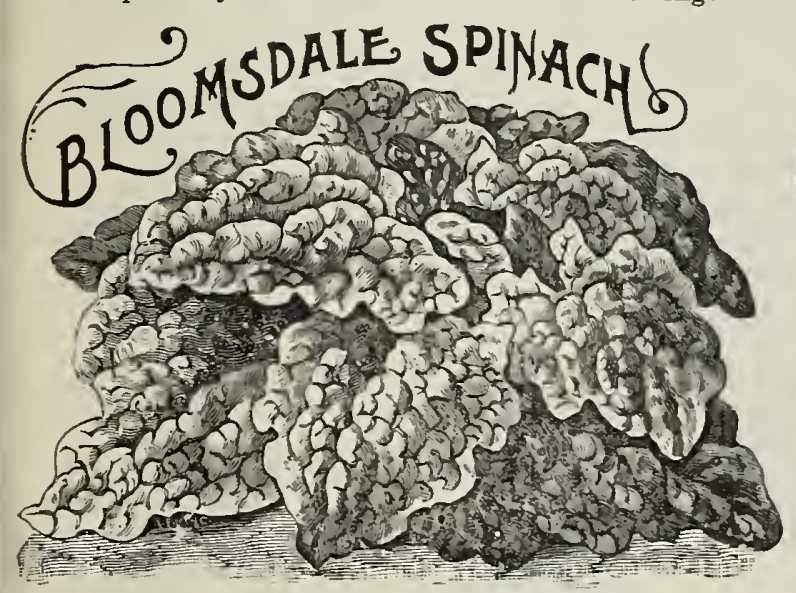

ROUND THICK-LEAVED.-The popular market variety; good fo thick. round leaves; an immense yielder.

TRIUMPH.- - large growing variety of the best quality that wiacket 5c, 1/4 pound 10c, pound $25 \mathrm{c}$ other sort. By its use the spinach season may be lengthened a whole month. Is not only long standing, but is also superior in quality and size.

VICTORIA.- - Heavy, broad, dark green leaves. pound $25 \mathrm{c}$ to seed.

Swiss Chard or Summer Spinach. "Cut and Come Again" Spinach. No vegetable requires less care than this, and it is safe to say that none yields as constantly as this spinach, producing uninterruptedly from July until winter. If your garden space is limited, Swiss Chard must have a place, for in ground occupied, Swiss Chard produces more food for the table than almost any other vegetable. The leaves are used for greens the same as spinach or beet tops, and are equal in quality to the former and far superior to the latter. Can be used all summer when spinach is not available. Later the leaves grow very large, with broad, flat, pure white stems and mid-ribs, which may be cooked like Asparagus or made into very good pickles.

Pkt. 5c, oz. 10c, 迸呫 20c, to 50c
SQUASH. Few fiarmers apprewinter squash as food for stock, and we strongly urge trying a patch for this purpose. Plant when dinger of frost is past in hills; put 6 or 8 seeds in a hill, thinning to 3 or 4 plants in a hill.

Giant Summer Crookneck.-Golden color, skin profusely warted, flavor superior.

Hubbard.-Flesh bright orange yellow, fine grained, very dry, sweet and richly flavored. Desirable for use throughout winter and spring.

Chicago Warted Hubbard.-Combines all the good points of the original Hubbard, with a rougher, harder, warted shell, making it especially valuable for shipping great distances.

\section{PRICES}

Packet 5c, ounce 10c, t pound 25c

Thacco. When the plants are about 6 inches high transplant into rows, 4 or 5 feet apart Connecticut Seed Leaf.-Perhaps the variety best adapted to the climate of the Middle and Northwestern States, being comparatively hardy.

Packet 5c, ounce 20c, $\frac{1}{2}$ pound $60 \mathrm{c}$ Havana.-Grown in this country commands a high price for cigar stock. Packet 5c, ounce 35c 
Sow in hotbed in early spring, or the seed may be sown in shallow boxes and placed in a window if one does not wish to have the trouble of a hotbed. Transplant to the open ground when all danger of irost is past, setting the plants three feet apart each way. Tomatoes do best on light, warm, not over-rich soil.

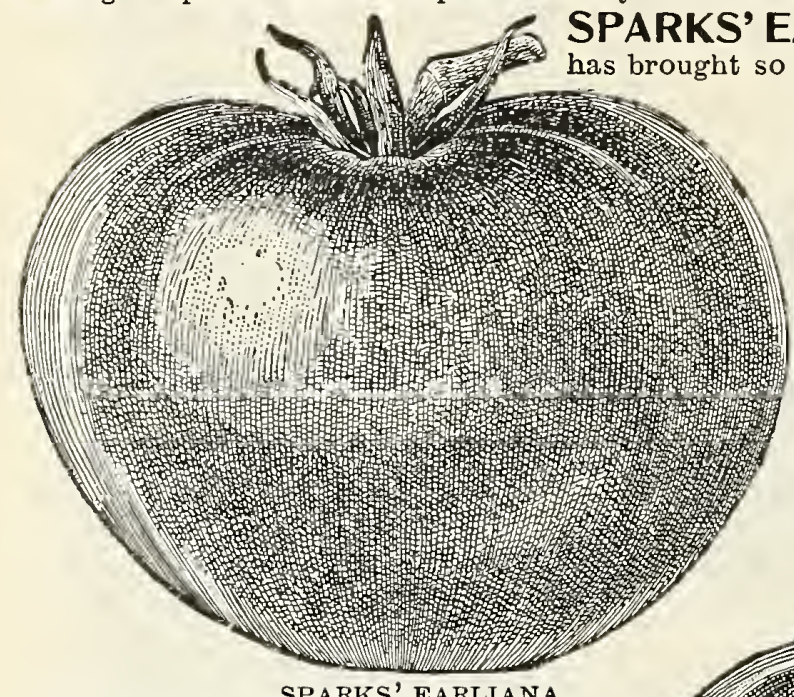

ARLIANA.-No Tomato ever int'r o d uced passed for a first-early variety, combining great size. The fruit grows very uniform, of fine shape, and is a bright red. Very solid and immensely productive.

Packet 5c, ounce 25c, $\frac{1}{4}$ pound $80 \mathrm{c}$

Chalk's Early Jewel.-Within a week to ten days as early as Earliana, it is even a heavier cropper, with fruit of larger size and sweeter flavor-produced continuously.

Packet 5c, ounce $25 \mathrm{c}$, $\frac{1}{\mathrm{t}}$ pound $80 \mathrm{c}$ Acme.-Size medium, color red with tinge of purple; flesh deep scarlet, very solid.

Packet 5c, ounce $20 \mathrm{c}$, t pound $60 \mathrm{c}$

SPARKS' EARLIANA

CREAM CITY.-One of the first large tomatoes to ripen, coming about a week ahead of Acme. Smooth, round, purplishcrimson; flesh thick, firm and solid; good shipper. Pkt. 5c, oz. 20c, $\frac{1}{4} \mathrm{fb} 60 \mathrm{c}$ DWARF CHAMPION.-Stem short, thick, stiff, almost self-supporting. The dwarf, upright habit makes it very desirable, as it can be planted more closely. Fruit quite large, solid and of good color.

Packet 5c, ounce 25c, $\frac{1}{2}$ pound $75 \mathrm{c}$ Ponderosa.-This is the largest fruited tomato and is of fine quality; deep purple.

Packet 5c, ounce $30 \mathrm{c}$, $\frac{1}{4}$ pound $\$ 1.00$

Stone.-Perfectly smooth, bright scarlet, very solid, good shipper. Pkt. $5 \mathrm{c}$, oz. $20 \mathrm{c}, \frac{1}{4} 7 \mathrm{tb} 60 \mathrm{c}$ MATCHLESS.-The best large-fruited, bright red,

BEAUTY. - Large uniform, smooth; flesh pink, skin 


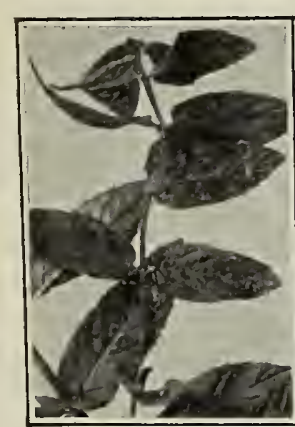

P EPPERMTNT

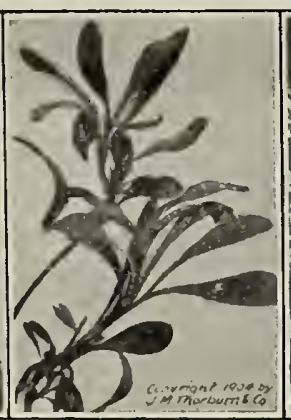

LAVENDER

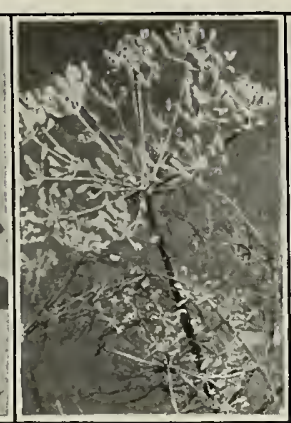

FENNEL

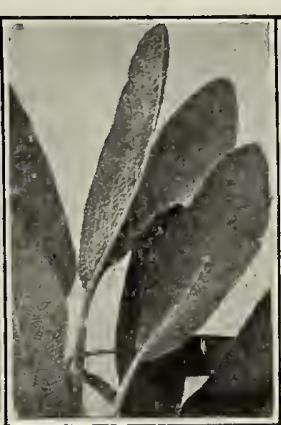

SAGE

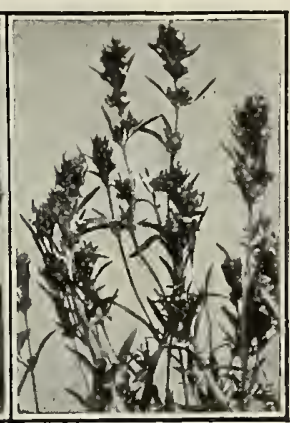

SUMMER SAVORY

\section{Seeds of Aromatic, Medicinal and Pot Herbs}

Most of the varieties thrive best on sandy soil. The soil should be carefully prepared and well cultivated, as the young plants are for the most part delicate and easily choked out by weeds. The stalks should be cut when in bloom, wilted in the sun, and thoroughly dried in the shade.

Anise. For garnishing, seasoning and for cordials; aromatic odor and taste........ Asperula Odorata. (Waldmeister.) For flavoring May wine; keep moist and shaded Basil, Sweet. For flavoring soups and sauces; fine and broad leaved............

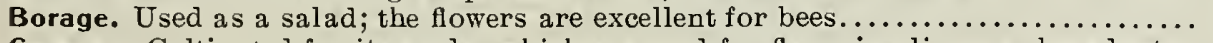
Caraway. Cultivated for its seeds, which are used for flavoring liquors, bread, etc. . Catnip. Has medicinal qualities; also grown for bee pasture..................

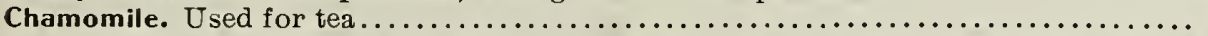
Chervil. More beautiful than parsley, and used for garnishing and flavoring dishes Coriander. Seeds have an agreeably aromatic $t$ aste, and are used in confectionery.. Dandelion. Thick Leaved. Is fast becoming a favorite spring green; very profitable Dill. Aromatic odor and warm, pungent taste; added to pickled cucumbers to flavor Fennel. Sweet. Seeds are used for flavoring, the leaves for garnishing........... Lavender. Grown for its flowers which are used in the manufacture of perfumes..... Marjoram, Sweet. The tops are used green for flavoring, or dried for winter use.... 05 Peppermint. For flavoring and for the distillation of the essence of peppermint.... 10 Pimpinella. The young tender leaves are used as salad; flavor like cucumbers...... 05 Poppy. White or blue seeded; used for baking, fresh seed................... Rosemary. Fragrant; yields an aromatic oil and water; leaves used for seasoning.. Saffron. For medicine and for coloring; also to make cosmetic powder called rouge 05 Sage. Used very extensively for flavoring and dressing; also in medicine.......... 05 Savory, Summer. (Bohnenkraut.) Extensively used for flavoring, especially beans. 05 Sorrel. Esteemed as salad, cooked as greens, etc. Leaves of mild, acid flavor...... 05 Tarragon. The leaves, either dried or fresh, are highly esteemed for seasoning..... 10 Thyme. A medicinal and culinary herb; used for seasoning and dressing......... 05 Wormwood. Used as a tonic and dressing for bruises; benificial for poultry; bitter. 05

$\begin{array}{ccc}\text { Pkt. } & \text { Oz. } & 4 \mathrm{Oz} \\ 05 & 10 & 25 \\ 10 & & \\ 05 & 20 & 40 \\ 05 & 10 & 30 \\ & 05 & 15 \\ 05 & 30 & \\ 05 & & \\ 05 & 15 & 30 \\ 05 & 10 & 25 \\ 10 & 50 & \\ 05 & 08 & 15 \\ 05 & 10 & 25 \\ 05 & 20 & 50 \\ 05 & 15 & 45 \\ 10 & & \\ 05 & 20 & \\ & 05 & 15 \\ 05 & 30 & \\ 05 & 10 & 30 \\ 05 & 15 & 40 \\ 05 & 10 & 25 \\ 05 & 15 & 40 \\ 10 & & \\ 05 & 25 & \\ 05 & 20 & \\ & & \end{array}$

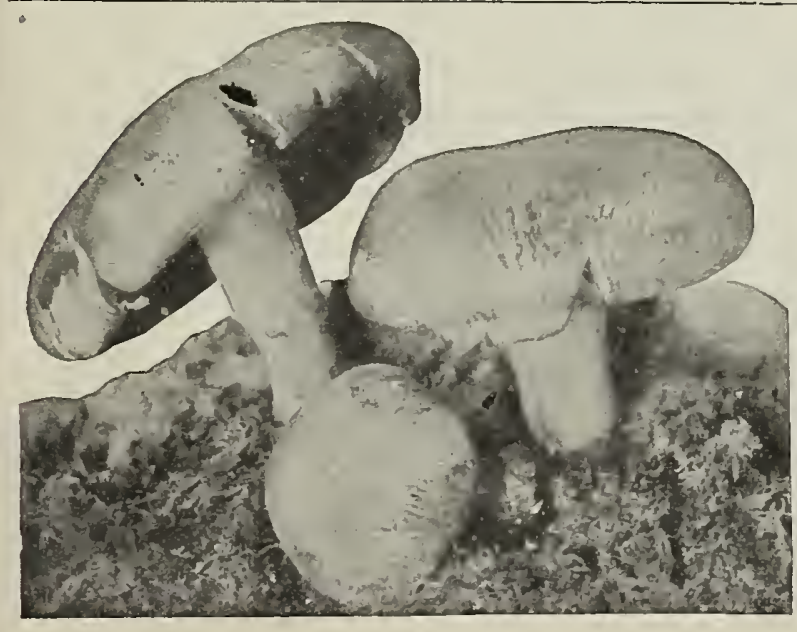

Mushroom Spawn

With each order we furnish free our leaflet, "How to Grow Mushrooms", giving plain, concise directions. By following these, anybody can grow this most luxurious and most highly prized of all vegetables. A more complete treatise, illustrated, will be mailed for the sum of 15 cents.

Pure Culture Spawn.-This is the resuit of careful and scientific experimenting and represents the highest development in spawn making. The process of production insures freedom form inferior types, increasing the yield, size and quality. We offer the cream white variety, which is hardy and very productive.

Per brick 20c, 10 bricks $\$ 1.75,25$ bricks $\$ 3.75$ 100 bricks $\$ 12.00$

If to go by mail, add 10 cents per brick for postage. 


\section{Selected Farm Seeds.}

We give special attention to the quality of our Farm Seeds, and send out nothing but most carefully selected and recleaned stock. It is our purpose to supply the very best only. Prices on Farm Seeds subject to market changes. Purchaser pays freight in all cases.

\section{CHOICE SEED FIELD CORN.}

THE SEED CORN we offer is grown specially for that purpose, carefully selected, cured and shelled. It will pay any enterprising farmer to secure seed of the promising new varieties. Such men isvariably obtain highest market prices for all they can produce.

Silver King-Wisconsin No. 7. The best white corn for Wisconsin and the Northwest.

Can be planted with safety anywhere in the Northwest with certainty of its ripening.- It is a pure white dent corn with a white cob. The kernel is broad and deep: forms a perfectly cylindrical ear, about 8 or 9 inches long, well filled to the tips and butts. The stalks are rather short and heavy averaging 8 to 11 feet in height, and are very leafy.

Quart $15 \mathrm{c}$, peck $75 \mathrm{c}$, bushel $\$ 2.50$

Wisconsin No. 8. The earliest Yellow Dent Corn grown. This corn was secured by the Wisconsin Experiment Station from Prof. Hays of the Minnesota Experiment Station as Minnesota No. 13. It is noted for its early maturity, and can be depended upon to ripen anywhere in Wisconsin, and is especially adapted for the lake shore counties and northern Wisconsin. It makes a fairly large stalk growth, well clothed with leaves. The ears average 7 to 8 inches long.

Quart 15c, peck 75c, bushel $\$ 2.50$

Sanford's Early White Flint.-The ears are of unusual length and of handsome shape, flinty white color. Plant is of sturdy, vigorous growth. The stalks usually bear 2 or 3 long ears.

Per quart $10 \mathrm{c}$, peck $50 \mathrm{c}$, bushel $\$ 1.50$.

Longfellow Yellow Summer Flint.--Farmers' Favorite; a very early, productive and desirable $\nabla$ ariety.

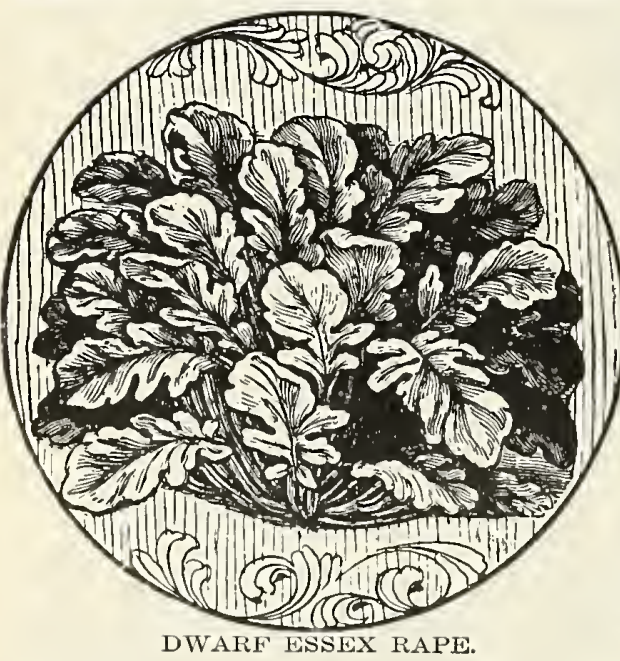

Per quart $10 \mathrm{c}$, peck $50 \mathrm{c}$, bushel 1.50

Red Cob Ensllage.-A most desirable variety, adapted to all sections of the country. It is sweet, tender and juicy; has short joints, abundance of leaves and grows to a good height. Per quart $10 \mathrm{c}$, peck $35 \mathrm{c}$, bushel 1.00

\section{Dwarf Essex Rape}

The main secret in the successful raising of sheep for mutton, for which the Rnglish are so famous, lies undoubtedly in the very general use of Fodder Rape for feeding them. Dwarf Essex is easily grown and perfectly hardy, and possesses remarkable fattening properties. Pigs and cattlo are also very fond of it. The plant is a rank grower and should have heavy manuring, as well as high cultivation. Any corn soil will grow Rape. Sow the seed during the third or fourth week in June; it can then resist drouth, and the crop can be ready to fsed at a season when it is most needed. By sowing different piecer several weeks apart a continuous supply of good feed can be had.

Per pound 15c, 10 pounds $\$ 1.00$.

MAMMOTH RUSSIAN SUNFLOWER.--The best variety for the farmer, growing to double the size of the common and the yield is twice as great. It is highly recommended for poultry 1 pound $8 \mathrm{c}, 5$ pounds $35 \mathrm{c}, 25$ pounds $\$ 1.50,100$ pounds $\$ 5.00$

\section{ROOT CROPS FOR FARM STOCK}

It is not what an animal eats but what it digests and assimilates, that is of benefit to the owner. When fed on a ration containing something green or fresh appetite is stimulated; the digestion is more perfect, and the general health and restful content greater. In addition, loots contain high quantities of nutritious sugar, and are a necessity in the rations of growing and fattening animals.

MANGELS, SUGAR BEETS, CARROTS, RUTABAGAS, TURNIPS. 


\section{SEED GRAIN.}

Prices on Seed Grain subject to market changes.

Grown expressly for Seed.

Carefully recleaned and selected.

BARLEY. Mandsheuri.--The very best six-rowed barley grown. Heads long, heavy, drooping and well filled, containing 75 to 90 grains each. Straw bright, very strong; does not lodge on the richest land. It is early in ripening and always plump; yields from 50 to 60 bushels per acre. Considered superior for malting. Long heads; distinguished from common sorts by a slightly reddish tint to the beard.

BUCKWHEAT. Japanese.-This variety is rapidly displacing all other sorts of Buckwheat. It ripens early and has much larger grains than all others. In shape the kernels are peculiar and distinct. Color a dark brown. It manufactures a superior flour.

Peck 45c, bushel $\$ 1.40$

OATS. SwEDISH SELECT.-Greatest of all Oats. They outyield all others. They are the heaviest, weighing from 36 to 40 pounds per bushel. The straw is very stiff and will not lodge. Fine appearance; large, thick and plump; color pure white; heads upright and bushy. Hull very thin, almost all meat; this makes them valuable as feeding oats. Great root development, making it drought proof. It adapts itself to all soils and climates. It is the earliest of all heavy yielding sorts. It is free from rust and smut.

Bushel $\$ 1.10$, 10 bushels $\$ 10.00$

MACARONI WHEAT. This wheat is fast taking the place of the old standard varieties of bread wheat all over the Northwest. It yields more, grades higher, and is especially adapted to resist dry weather.

\section{SPRING RYE.}

Peck 45c, bushel $\$ 1.60$

MILLET. Height 2 to three feet; succulent stem; leaves broad and numerous, grows rapidly, an matures early. Can be planted as late as August and mature a crop of hay the same season. Sow bushel per acre. 50 pounds to the bushel.

Market Price

HUNGARIAN GRASS. (Panicum Germanicum).--One of the most valuable annual soiling plants. It grows on ordinary soil; withstands drought well. As it is of very rapid growth, being ready for cutting within sixty days, it may be sown in this latitude as late as middle of July for hay or middle of August for green fodder. It should be cut just before blooming. Sow one bushel to the acre. 48 pounds to the bushel.

Market Price

FIELD PEAS. Valuable in northern climates for cattle feeding, being especially valuable for milch cows. Excellent for horses and pigs when sown with oats. Sow broadcast and harrow in at the rate of two bushels per acre; with oats use one bushel.

Market Price

\section{GRASS AND CLOVER SEEDS}

\section{Prices on Application. They are Subject to Market Changes.}

тімотнY.-It makes the best hay for horses and market of the entire list. We handle strictly pure stock for those who want the best only. Sow 15 to 25 pounds to the acre. Bushel weighs 45 pounds. KENTUCKY BLUE GRASS.-Valuable pasture grass and for lawns when mixed with other grasses. Sow about 30 pounds to the acre. Our seed is almost free from foreign and chaffy matter, contains none of the cheaper Canadian Blue Grass, and shows a very high percentage of germination.

RED TOP.- This is one of the most generally useful agricultural grasses we have and is particularly valuable on low, moist lands. We offer carefully re-cleaned solid seed, weighing about 32 pounds to the measured bushel. Sow 16 pounds of this to the acre.

PERENNIAL RYE GRASS.-Nutritious, and valuable both for pastures and meadows; starts early. MEDIUM RED CLOVER.-The common clover in general cultivation. It is the best for hay. When used alone, sow about 8 pounds of seed per acre; 60 pounds to the bushel.

WHITE CLOVER.-Low; one of the best of the Clovers for permanent pasturage, but prefers moist land. Sow 6 pounds per acre when used alone, or 3 pounds with grass seeds. 60 pounds to bushel.

ALSIKE OR SWEDISH CLOVER.- Hardy, resists extremes of drought and wet, yields large crops of superior pasturage, and much liked by cattle. Blossom heads round, resembling White Clover in shape, flesh colored, sweet and fragrant; much liked by bees. Sow 6 pounds per acre in spring or fall; 60 pounds to the bushel.

ALFALFA OR LUCERNE.-Alfalfa under ordinary conditions yields three to four cuttings per year, yielding a good four to five tons per acre. The hay has a feeding value almost equal to grain, and while producing is an actual benefit to the soil on account of its nitrogen gathering bacteria on the roots. Sow 20 poands to the acre; 60 pounds to the bushel. Our seed is American grown and of the best quality. 


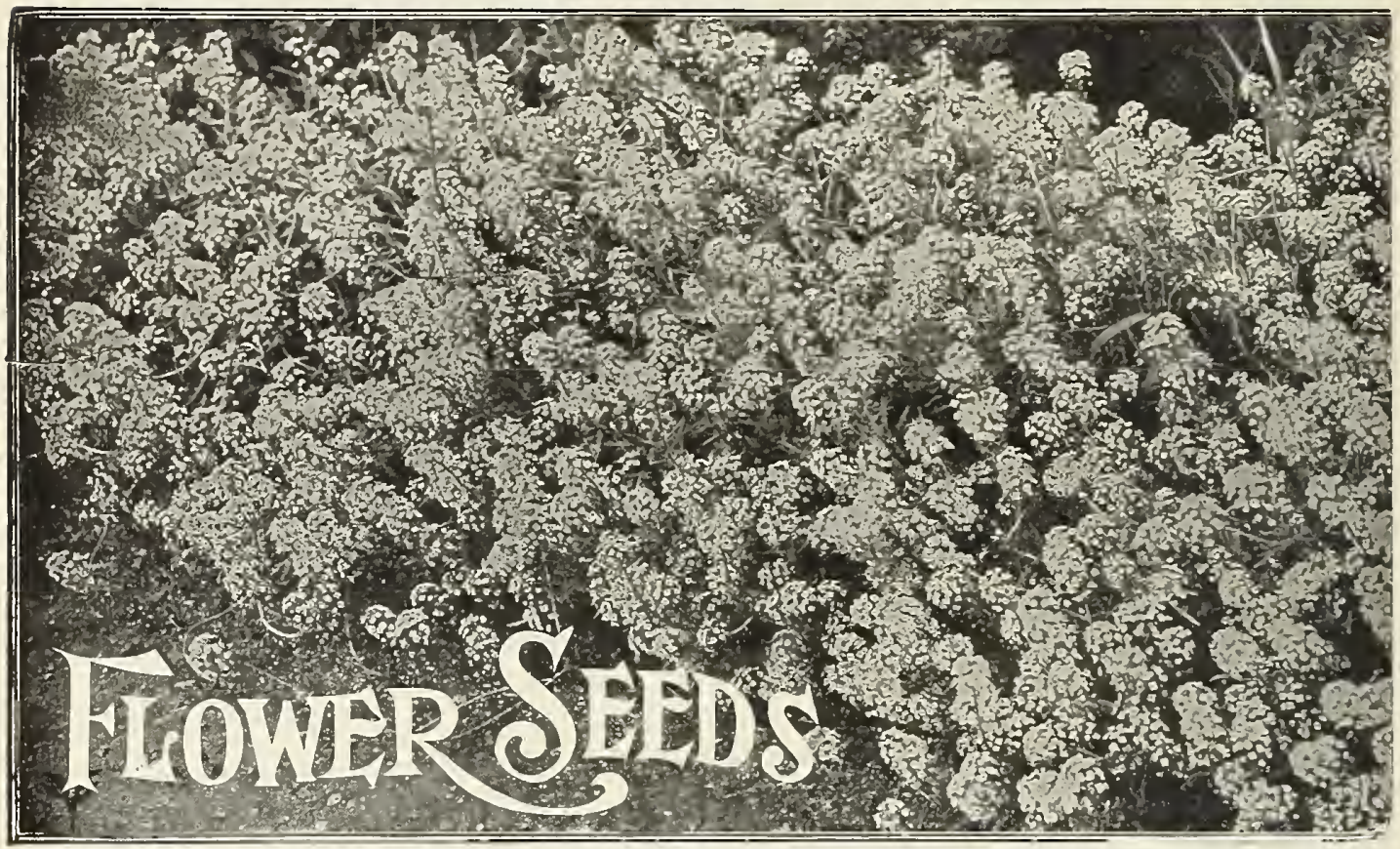

LARGE-SIZED PACKETS Our packets are very large, and contain in most eases more seed tity usually contained in the papers offered by department and some other stores. We have always found the liberal treatment of our customers to be the best paying feature of our business.

\section{ALL. FLOWER SEEDS SENT POSTPAID ON RECEIPT OF PRICE}

\section{GENERAL DIRECTIONS FOR CULTURE}

For all flower seeds which should be started indoors, and this includes many of our best and brightest summer flowers, such as Heliotrope, Celosia, Lobelia, Salvia, Vinca, Verbena, etc., the best plan is to sow in earthenware seed pans or boxes (about 2 inches deep), which should be filled to the depth of an inch with broken pots, coal ashes, or any rough material that will furnish perfect drainage. The upper inch should be nicely sifted soil, composed, if possible, of about one-third each of sand, leaf mould and light garden loam. Press firmly and evenly, and water thoroughly the day before sowing.

A common mistake in sowing flower, as well as other seeds, is covering too deep. As a general rule, cover only to the depth of the thickness of the seeds; or with medium-sized seeds, like Balsams, Zinnisa, etc., half an inch or so is none too much. Such fine seed as Portulaca needs only to be pressed into the soil with a piece of board or the palm of the hand. Always press the earth down firmly after sowing all flower seeds, else there is danger of their drying up before the roots can get firm hold of the soil.

Cover with a pane of glass or one or two thicknesses of newspaper, to prevent the too rapid evaporation of the moisture, and keep in a temperature of between 60 and 70 degrees. Water carefully as needed. Remove the glass or covering after the seeds have germinated, and when the seedlings are large enough to handle they should be transplanted into similarly prepared boxes an inch apart each way, or put into small pots and kept in same until time to plant out in the open ground. At all times they should have an abundance of air, otherwise the young seedlings are liable to damp off.

Seeds of the hardier Annuals may be sown where they are to grow; but as a rule it is preferable to transplant, as the plants are generally stronger and stand drought better. During very dry weather, and when the seedlings are first set out, they should be watered frequently. Provide some support for all such Annuals as require it.

Seeds of Biennials and some Hardy Annuals may be sown in July and August in the open, and in September in boxes, and placed in coldframes. They will make strong plants by spring, and flower early. 


\section{Useful Lists of Annual Flowers for a Variety of Purposes}

20 OF THE MOST

\section{POPULAR ANNUALS}

Alyssum, Sweet

Aster

Balsam

Candytuft

China Pinks

Coreopsis

Mignonette

Marigold

Nasturtium

Pansy

Petunia

Phlox

Poppy

Portulaca

Salvia

Sca biosa

Stocks

Sweet Peas

Verbena

Zinnia
20 OF BEST ANNUALS FOR CUTTING

Alyssum, Sweet

Aster

Candytuft

Chrysanthemum

Coreopsis

Cornflower

Cosmos

Gaillardia

Gypsophila

Larkspur

Marigold

Mignonette

Nasturtium

Phlox

Sca biosa

Suntlower

Stocks

Sweet Peas

Sweet Sultan

Zinnia

\section{ANNUALS DELIGHT. ING IN SUN \\ Balsam \\ Escholtzia \\ Gaillardia \\ Hyacinth Bean \\ Nasturtium \\ Portulaca \\ Salvia \\ Verbena}

\section{BEST CLIMBERS}

Canary Bird

Cobra

Cypress Vine

Hyacinth Bean

Japanese Hop

Moonflower

Morning Glory

Nasturtium

Ornamental Gourds

Wild Cucumber
6 ANNUALS THAT DO

WELL IN SHADE

Adonis

Begonia

Godetia

Musk

Pansy

Violet

12 DWARF ANNUALS FOR EDGING

Ageratum

Alyssum

Bellis

Forget-me-not

Lobelia

Dwarf Marigold

Nasturtium

Phlox

Poppy, California

Portulaca

Pansy

Verbena

\section{Blooming Periods of Annuals Arranged by Months}

\begin{tabular}{|c|c|c|}
\hline $\begin{array}{c}\text { SIX ANNUALS THAT BLOOM IN } \\
\text { MAY }\end{array}$ & $\begin{array}{c}\text { SIX ANNUALS THAT BLOOM IN } \\
\text { JULY }\end{array}$ & $\begin{array}{c}\text { SIX ANNUALS THAT BLOOM } \\
\text { SEPTEMBER }\end{array}$ \\
\hline Alyssum, Sweet & China Pinks & Ageratum \\
\hline Godetia & Cor & As \\
\hline Marigold & Lar & Cos \\
\hline Phlox & rtium & $\mathrm{Sa}$ \\
\hline Stocks & & \\
\hline Violet & Peas & Zinnia \\
\hline $\begin{array}{l}\text { SIX ANNUALS THAT BLOOM IN } \\
\text { JUNE }\end{array}$ & $\begin{array}{c}\text { SIX ANNUALS THAT BLOOM IN } \\
\text { AUGUST }\end{array}$ & $\begin{array}{c}\text { SIX ANNUALS THAT BLOOM } \\
\text { OCTOBER }\end{array}$ \\
\hline Candytuft & Aster & Alyssum, Sweet \\
\hline Forget-me not & & Canc \\
\hline Mignonette & Gaillardia & Cosmos \\
\hline Nasturtium & Nasturtium & Marigold \\
\hline & & \\
\hline Stocks & Verbena & Zinnia \\
\hline
\end{tabular}

\section{Planting Calendar for Annuals}

These dates are approximately correct for this latitude, but may vary somewhat in abnormal seasons.

Feb. 1. Tender annuals indoors.

Mar. 1. All annuals indoors or in hotbeds for early bloom.

Mar. 15. Sweet Peas outdoors.

Apr. 1. Hardy annuals outdoors if ground is in condition.

Apr. 15. All hardy annuals outdoors. Set out plants of annuals that have been hardened off.

May 1. Second seeding of annuals for later blooming. Set out seedlings of hardy annuals; also Dahlias and Gladioli.

May 15. Set out tender annuals.

June 1. Set out bedding plants; sow all annuals for late fall blooming.

GARDENING BY CHILDREN
No occupation is as healthy, innocent or instructive to a child as a practical study of nature. No matter how small the space of ground the pleasure to a child of cultivating a little garden will always develop ambition, and the pleasure of observing the growth from the day the seed sprouts until the plants attain perfection is in itself a lesson which both young and old can appreciate. The good, wholesome benefit derived by the children must necessarily cultivate the mind, while at the same time amuse.

Heads of Institutions and School Managers would do well to cultivate in the minds of the children under their charge a love of nature and the beautiful.

Annual flowers such as Balsam, Mignonette, Four O'Clocks, China. Pinks anò Phlox are all easily raised end afford a showy display at small cost and little labor.

In Vegetable Seods our selection in unexcelled. 
The pleasure resulting from a large and varied collection of flowers will amply repay for time and labor spent.

N the following pages we describe the leading flowers grown from seed, including many New and

Special Flowers of unusual beauty. These seeds are all of the finest strains of the best varieties and are sure to give entire satisfaction. They are procured without respect as to cost, from the best growers of the particular kinds in America and Europe, and the whole makes a collection unexcelled in quality, and vastly superior to the stock usually sold.

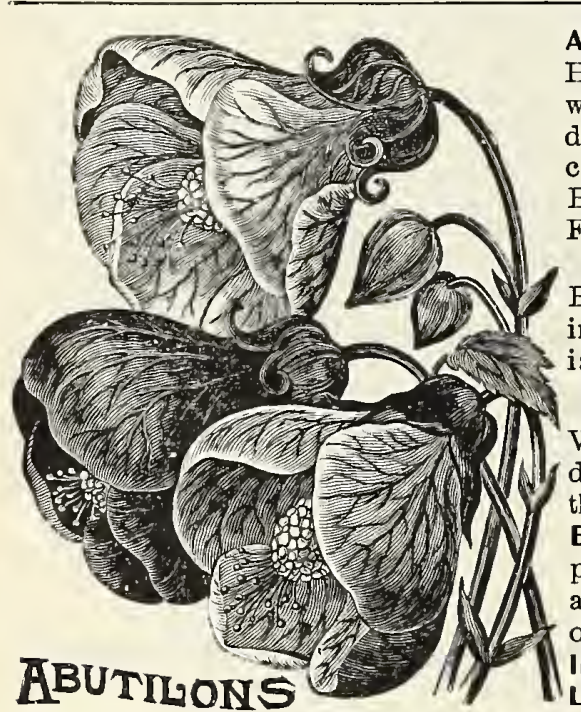

ABUTILON. Flowering Maple Handsome bushes covered with bell-shaped flowers in the daintiest a nd also strongest colors, dotted and veined. Blooms readily from seed. Fine hybrids mixed. Pkt. 15c ADONIS

Bright crimson flowers, peering from finely cut dark foliiage.

\section{Ageratum}

Very effective plants for bedding; they remain in bloom throughout the summer.

Blue Perfection.-Dwarf compact growth; its color is deep

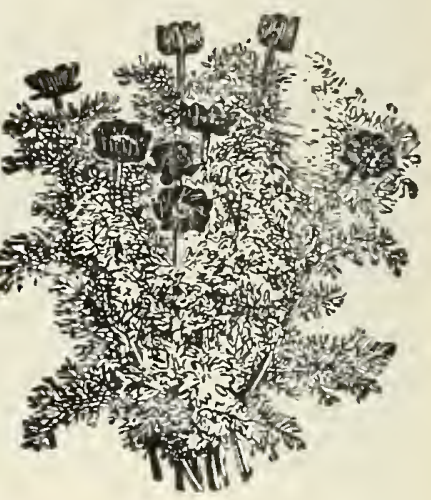

ADONIS amethyst blue, and has nothing of the faded-out appearance of the old style Ageratum. Imperial Dwarf Blue.-Good for ribbon borders. Pkt. 5c Little Blue Star.-The tiny bushy plants do not ezceed 4 or 5 inches in height, with clusters of flowers of light blue witn dark red center, changing to pure light blue. Packet 10c

SWEET ALYSSUM. A general favorite, with delicate white flowers of exquisite fragrance, very free blooming, suitable for beds, borders and rock-work; fine for cut. Benthami.-Best for cutting. Packet 5c, 南oz. 15c, oz. 25c Little Gem.-This should really be called the "Snow White Carpet Plant," for the plants, which are only a few inches high, grow so dense, and are so completely covered with snow white blossoms as to create the impression of a beautiful carpet spread over the ground. We know of no other white flower which is so particularly well adapted to borders, ribbon bedding, etc.

Packet 5c, $\frac{1}{\frac{1}{4}}$ ounce $15 \mathrm{c}, \frac{1}{2}$ ounce $25 \mathrm{c}$, ounce $40 \mathrm{c}$ Hardy Alyssum, Saxatile Compactum.-Brilliant gol den yellow spring bloomer; desirable for rock work. Pkt. 5c ANTIRRHINUM. See Snapdragon.

\section{AQUILEGIA.-COLUMBINE}

Very handsome hardy plants, two to three feet high; easy to grow, and bear a profusion of large flowers of novel form and in a great variety of colors. For planting in permanent borders or at the edges of shrubbery this old-fashioned favorite is one of the best of all.

Coerulea.-(Rocky Mountain Columbine). One of the most beautiful of our native American flowers. Sepals deep blue, petals white. Pkt. 10c Vulgaris, Single and Double Mixed.Vulgaris, Double Mixed.-

Asparagus Plumosus Nanus. (Asparagus Fern.) One of the prettiest house plants. The leaves are bright green, gracefully arched, surpassing Maidenhair Ferns in grace, delicacy of texture and richness of color.

Asparagus Sprengeri. Most handsome seen drooping gracefully fron pot or hanging basket; of fresh, light or apple green hue.

Packet $5 \mathrm{c}$

Packet 10c

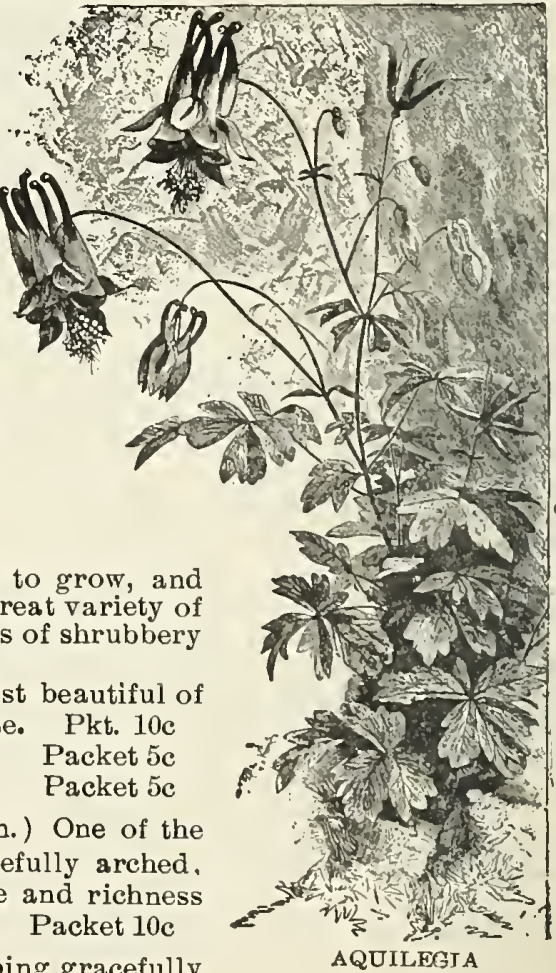

Packet 10c 


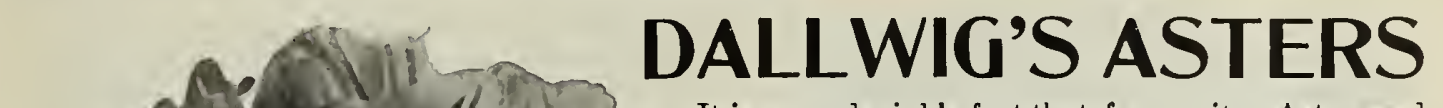

It is an undeniable fact that for purity, Aster seed grown in Germany is far superior to any grown elsewhere. The climate is better suited to the full development of the flowers, and the German growers have the experience of a century behind them. Ours is procured from careful and experienced growers, and is all German grown except the Branching, which is a superb variety of American origin.

Queen of the Market.-Very early extremely floriferous, medium sized variety, with long stems. Excellent for cutting. White Pink Deep Scarlet Dark Blue Light Blue Mixed.

Any color or mixed. Pkt. 5c, $\frac{1}{4}$ oz. 25c

Victoria.-One of the most handsome; large, perfectly double, globular and imbricated; fine pyramidal form. White Crimson Pink Light Blue Dark Blue Mixed.

Any color or mixed. Packet 5c, $\frac{1}{8}$ ounce $50 \mathrm{c}$

QUEEN OF THE MARKET

\section{Peony} ere very large, very double, and shaped like a peony. White Pink Dark Bloodred Light Blue Dark Blue Amethyst Mixed. Any color or mixed. Packet 5c, $\frac{1}{8}$ oz. 35c

Giant Comet.-This distinct class of Asters resembles very much the Japan Chrysanthemum in size and shape. The petals are long and beautifully curled. White Pink The Bride, white changing to pink, fine for cut Light Blue Dark Blue Mixed.

Hohenzollern.-The Hohenzollern is the finest of the Comet or Ostrich Feather type of Aster. It has long, wavy, twisted, feathery petals, like. the wavy, beautiful feathers of the ostrich. They are a valuable addition to the decorative class of Asters. F'lowers measure four inches across borne on stems twenty inches long. Pure White Pink Silvery Lilac Crimson Light Blue Dark Blue Mixed. Any color or mixed. Packet 5c, 市 ounce 35c

Branching.-A strong growing Aster whose tendency to form numerous branches is very marked. Therefore it should have more room than other asters. A rather late bloomer, thus giving its crop of flowers at a season when there is always a scarcity of bloom. The flowers are borne on very long stems, and are four inches and more in diameter. The petals are broad, long, and many of them more or less twisted or curled. White Lavender Purple Deep Pink Daybreak Pink Crimson Mixed. Any color or mixed. Pkt. 5c, $\frac{1}{8} \mathrm{Oz} .20 \mathrm{c}, \frac{1}{6} \mathrm{Oz} .35 \mathrm{c}$

ASPERULA ODORATA.-(Waldmeister.) Grown for its fragrant leaves and stems; used to flavor May Wine. It grows best among shrubbery in semi-shaded position where it can remain undisturbed. Flowers white. Packet $10 \mathrm{c}$ Any color or mixed. Pa c ket 5c, $\frac{1}{8}$ ounce $35 \mathrm{c}$

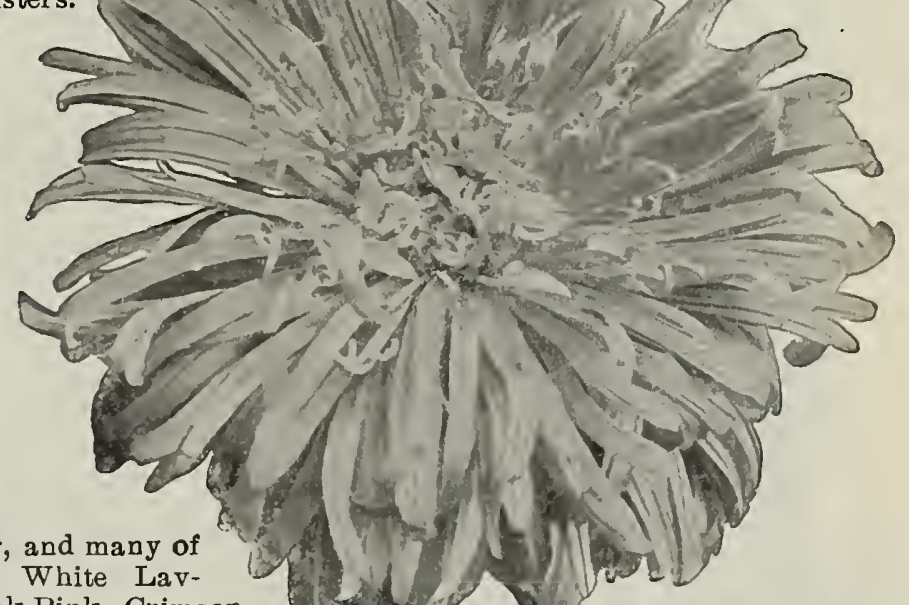

HOHENZOLLERN AURICULA.-(Primula.) A dwarf growing hardy plant, bearing umbels of fragrant flowers of many rish and beautiful colors.

Packet 10c

BEGONIA REX.--Grown for their large, beautiful, ornamental leaves. Unexcelled as a window plant.

Packet 25c 


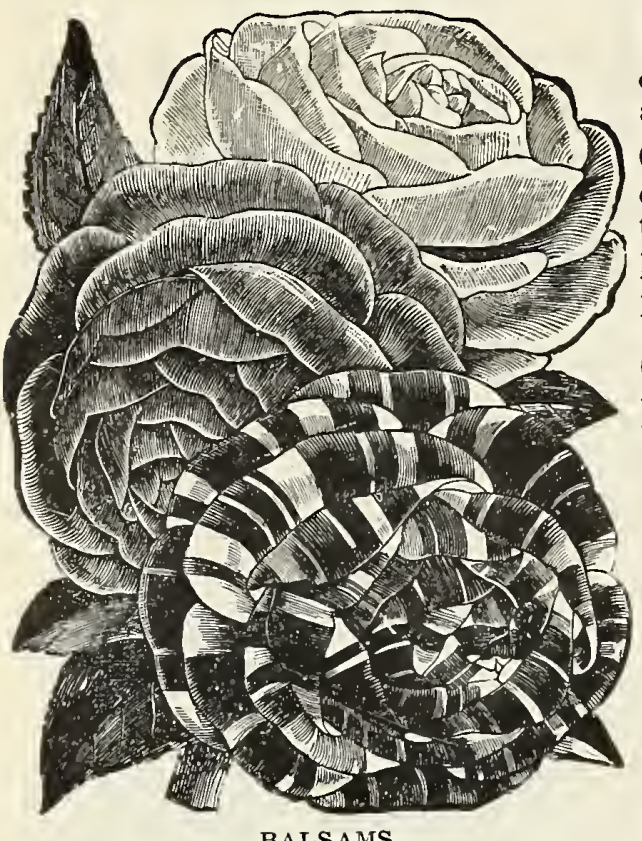

BALSAMS. owing to their handsome double flowers, brilliant colors and stately growth. Mixed colors.

Packet 5c

Giant-Flowered Browallia.-This large flowered Browallia is one of the best plants for bedding in the summer, and equally valuable for house culture in pots in winter. Grows a bout a foothigh, forming dense little bushes, which are covered with an abundance of the most delightful sky-blue flowers.

Packet 15c

Calceolaria.-Very handsome and showy plants for the greenhouse or house culture. The plants grow about 18 inches high and are covered with a great many curi-

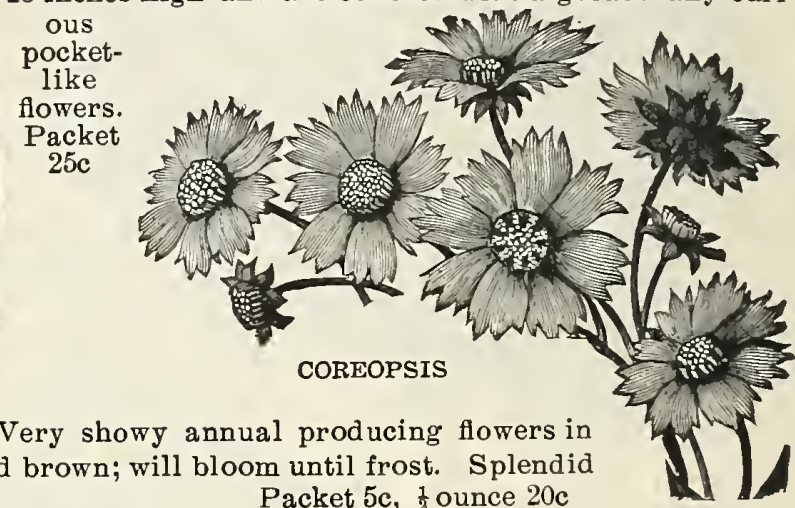

CALLIOPSIS or COREOPSIS.-Very showy annual producing flowers in every shade of yellow, orange, crimson and brown; will bloom until frost. Splendid for cutting.

Packet 5c, $\frac{1}{2}$ ounce 20c

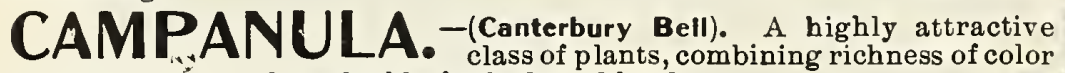
with stately growth; valuable for beds and borders.

Campanula Medium.-Blue, very pretty.

Campanula Medium.-Mixed.

Per packet 5c

Per packet 5c

Campanula. Cup and Saucer.-A beautiful variety; a most desirable and attractive addition to this class of old garden favorites. The bell or trumpet is nearly four inches in diameter, presenting the form of a cup, hence its name.

Per packet 5c

CANDYTUFT. (Iberis.)-Very useful for 1 bed etc., also for pots and for cut flowers for bouquets. A bed of Candytuft in colors makes a splendid display.

Queen of Italy. - An exceddingly free flowering dwarf,

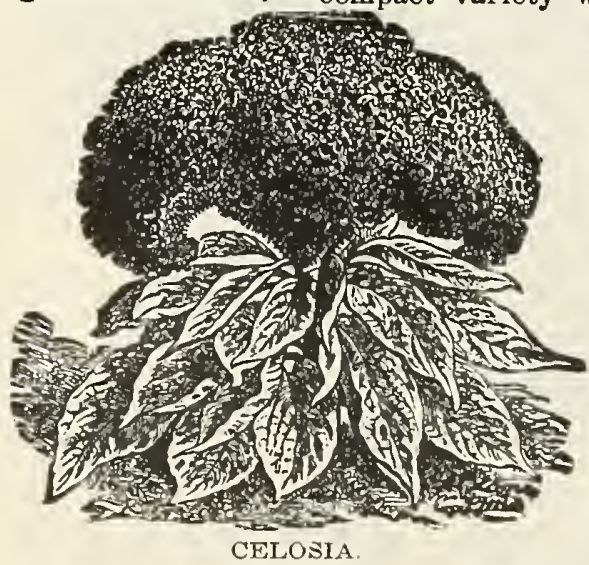
green foliage and delicate pink flowers; may be grown as annual or biennial; highly valuable for cutting purposes. Pkt. 5c Empress, - A beautiful ing candela variety bearbranches, each prcducing a large truss of pure wh ite flowers, presenting a perfect pyramid of CANTERBURY BELX

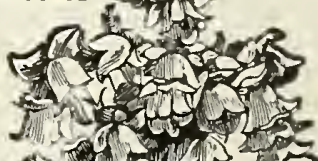
is 10 bloom througout the summer. See illustration Carmine.- Purple.- Dark Red.-
Mixed Colors.- $\begin{gathered}\text { White Rocket.- } \\ \text { Per packet 5c }\end{gathered}$ CELOSIA. Cockscomb. - A highly ornamental house culture.

Empress.-Crimson

Queen of Dwarfs.-Carmine. Fireking.-Bright red.

annual, valuable for bedding and Pres. Thiers. - Much used in public parks for bedding. Dwarf, with dark leaves and broad, stiff combs.

Aurea.-Yellow.

Above dwarf varieties mixed.

Per packet $5 c$ 


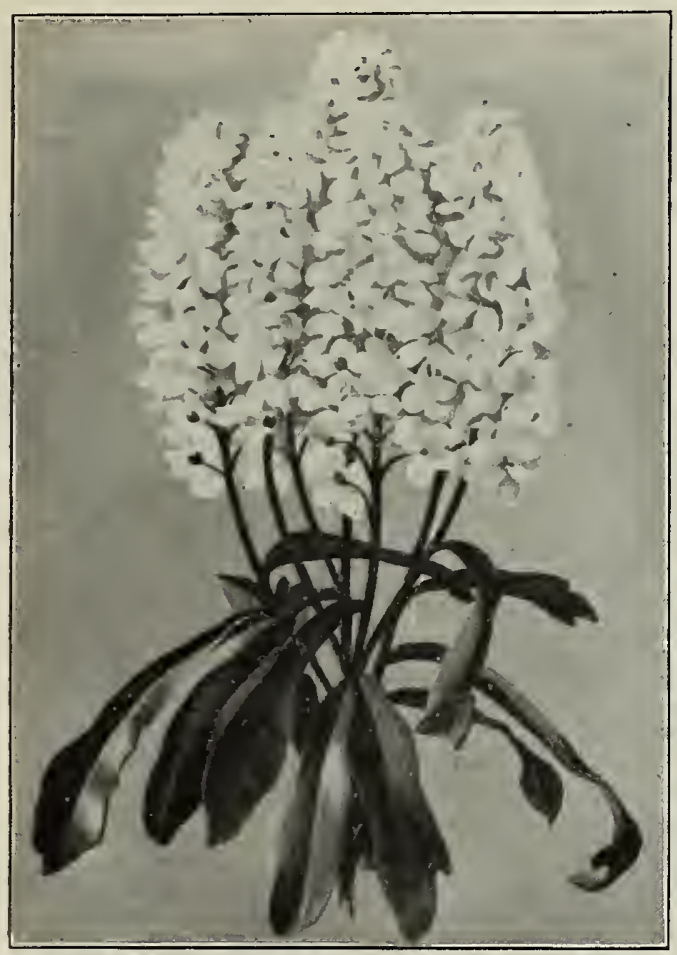

Empress Candytuft

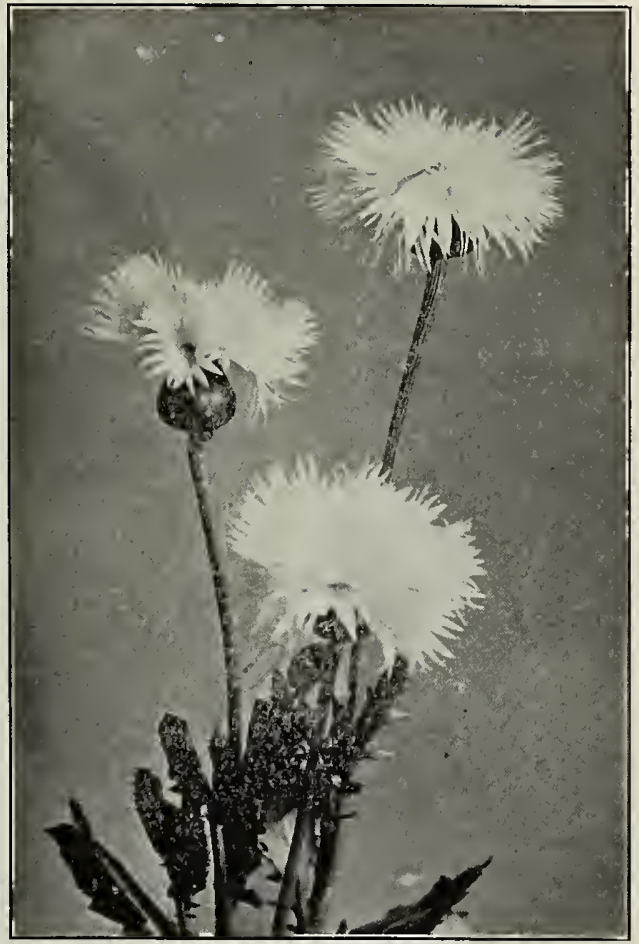

Centanrea Imperialis

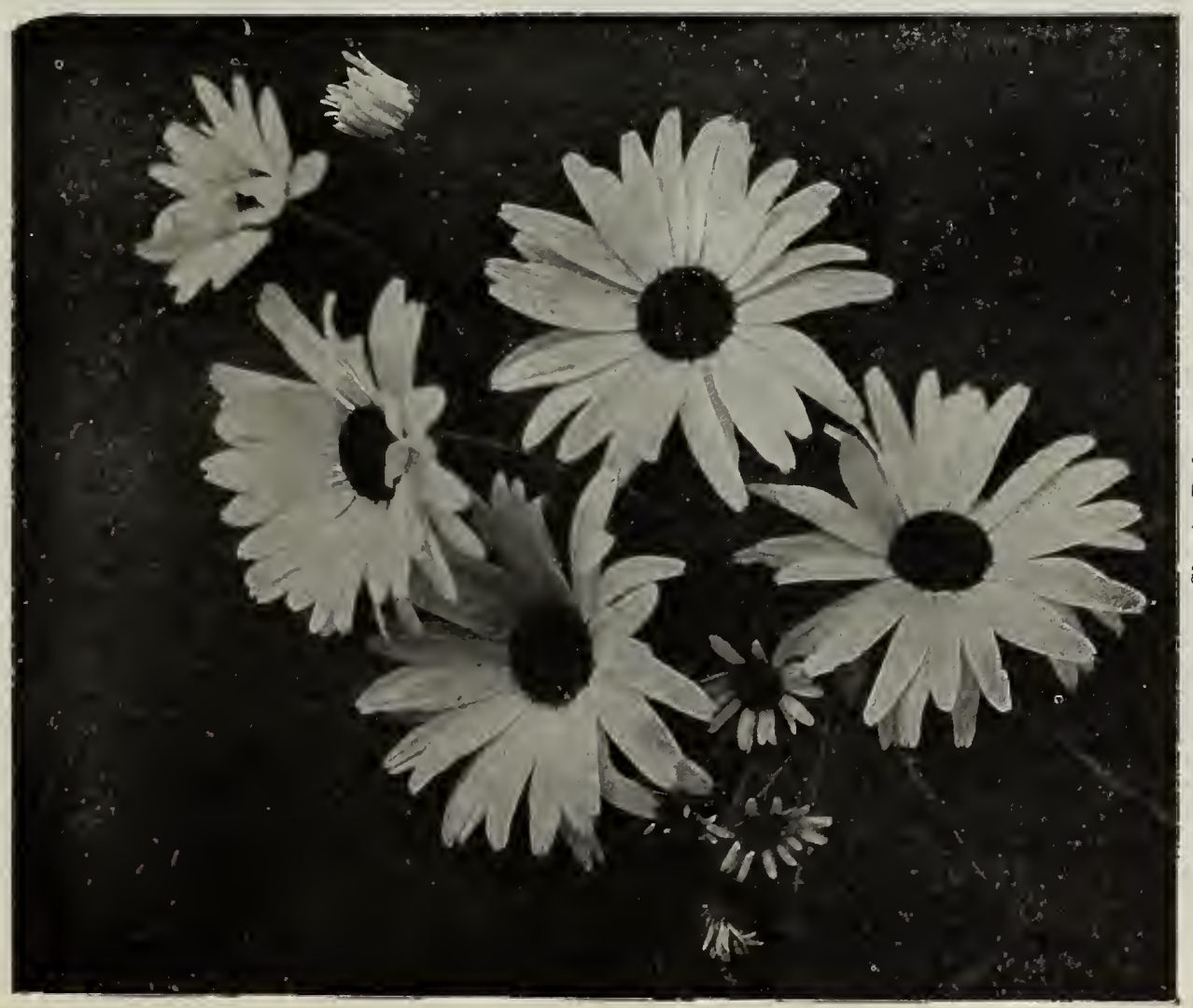




\section{Celosia Thompsoni Magnifica. - This represents the most per-} ostrich plumed Cockscombs. The plants have a true pyramidal branching growth, and the flower spikes vary in the most magnificent shades of colors, ranging from the clearest yellow to the darkest blood-red. Of great value for all decorative purposes in and out of doors. Packet $10 \mathrm{c}$

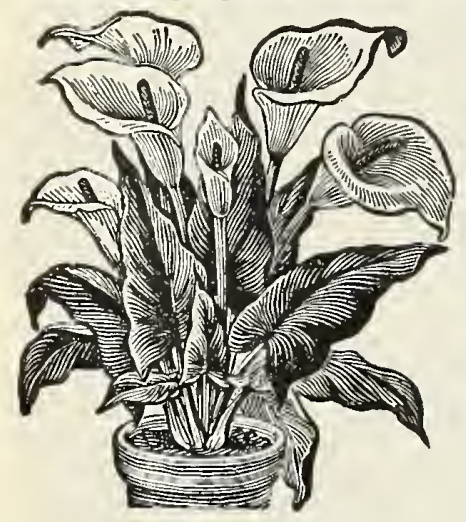

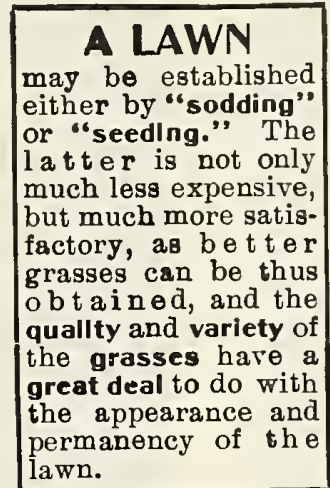

CALLA DEVONIENSIS.

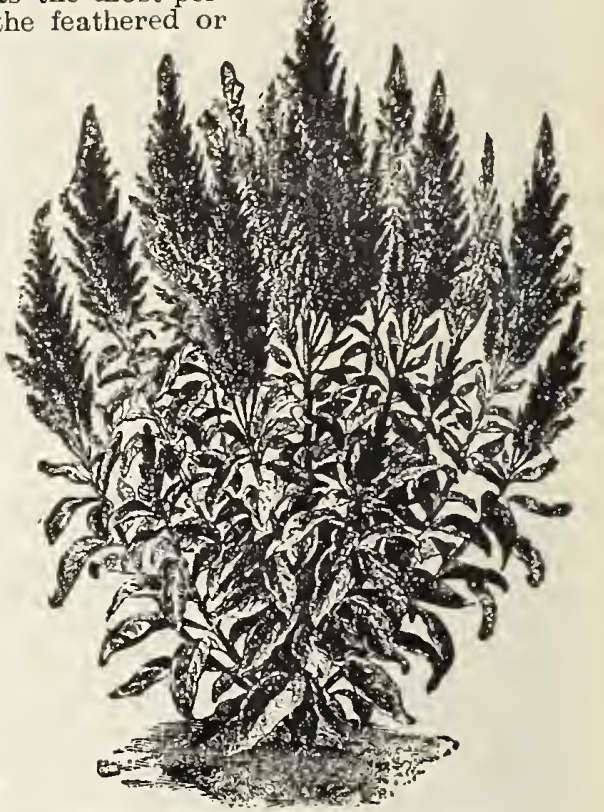

CELOSIA THOMPSONI MAGNIFICA.

Calla Devoniensis. Blooms the first year from seed The seedlings come true and will bloom profusely the first year. Its willingness to bloom is phenomenal, while its culture is of the simplest. Pure white, large blooms. borne on stout stalks.

Packet 10c

CARNATIONS. The seed we offer is saved from one of the finest collections in Europe.

Best Double Mixed.-Blooms the second summer from seed.

Double Red Grenadin.-Dwarf, compact growth; blooms early the second season.

Packet $5 \mathrm{c}$

Farly Double Dwarf Vlenna.-Produces double, sweet-scented flowers in large variety of colors an in great profusion. Blooms the second summer from seed.

Packet 5c

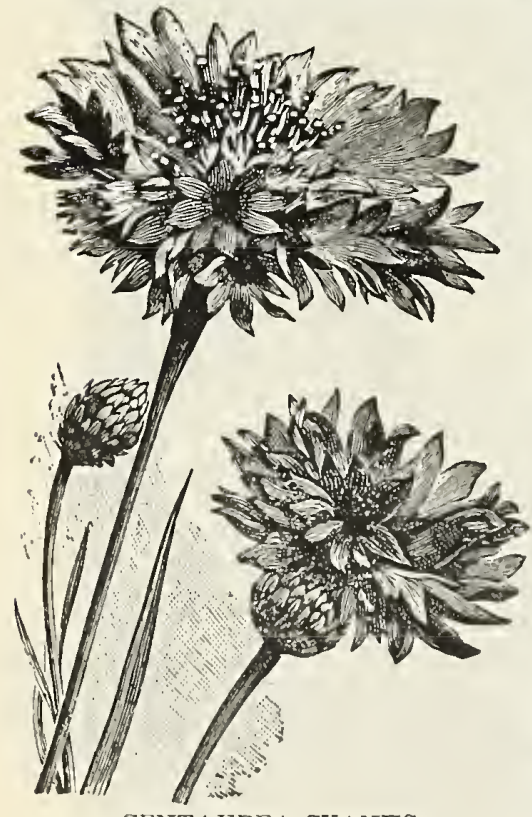

MARGARET.-These superb carnations are very popular, not only by reason of their fine double fragrant flowers, but also because they can be treated as annuals. Like the China Pinks they flower freely the first season from seed. They yield a profusion of fragrant flowers in great variety of colors.

Extra fine mixture.

Packet $5 \mathrm{c}$

DWARF MARGARET.-Like its parent, the Margaret, this carnation blooms in four months from sowing. Dwarf and erect growth. Extra fine mixture.

Packet 5c

Centaurea Cyanus. Known as Bachelor's Button, Corn Flower, Blue Bottle, Bluet, Ragged Sailor, etc. Fine for cut flowers.

Emperor WIIliam, single blue. Single Mixed. Double Mixed. Packet 5c

Centaurea Imperialis or Royal Sweet Sultan

Beautiful, sweet-scented, artistically shaped flowers borne on long, strong stems, and when cut will stand for a week in good condition. Of the easiest possible culture, and flowers continuously from early summer till autumn. See illustration on page 51. We offer the following colors:

Alba, pure white. Armida, lilac. Favorita, brilliant rose. Graziosa, dark lilac.

Suaveolens, yellow. Mixed. Gigantea Alba, new giant white. CENTAUREA ODORATA MARGARET.--Very handsome plants growing about 18 inches high and producing large, pure white CENTAUREA CYANUS flowers, exquisitely lacinated and delightfully scented. Being produced on long, stiff stems, the flowers are admirable for cutting. Packet 5c CENTAUREA GYMNOCARPA, or DUSTY MILLER.-This is planted for its silvery gray foliage, not for flowers; for bedding and borders. Packet 5c 


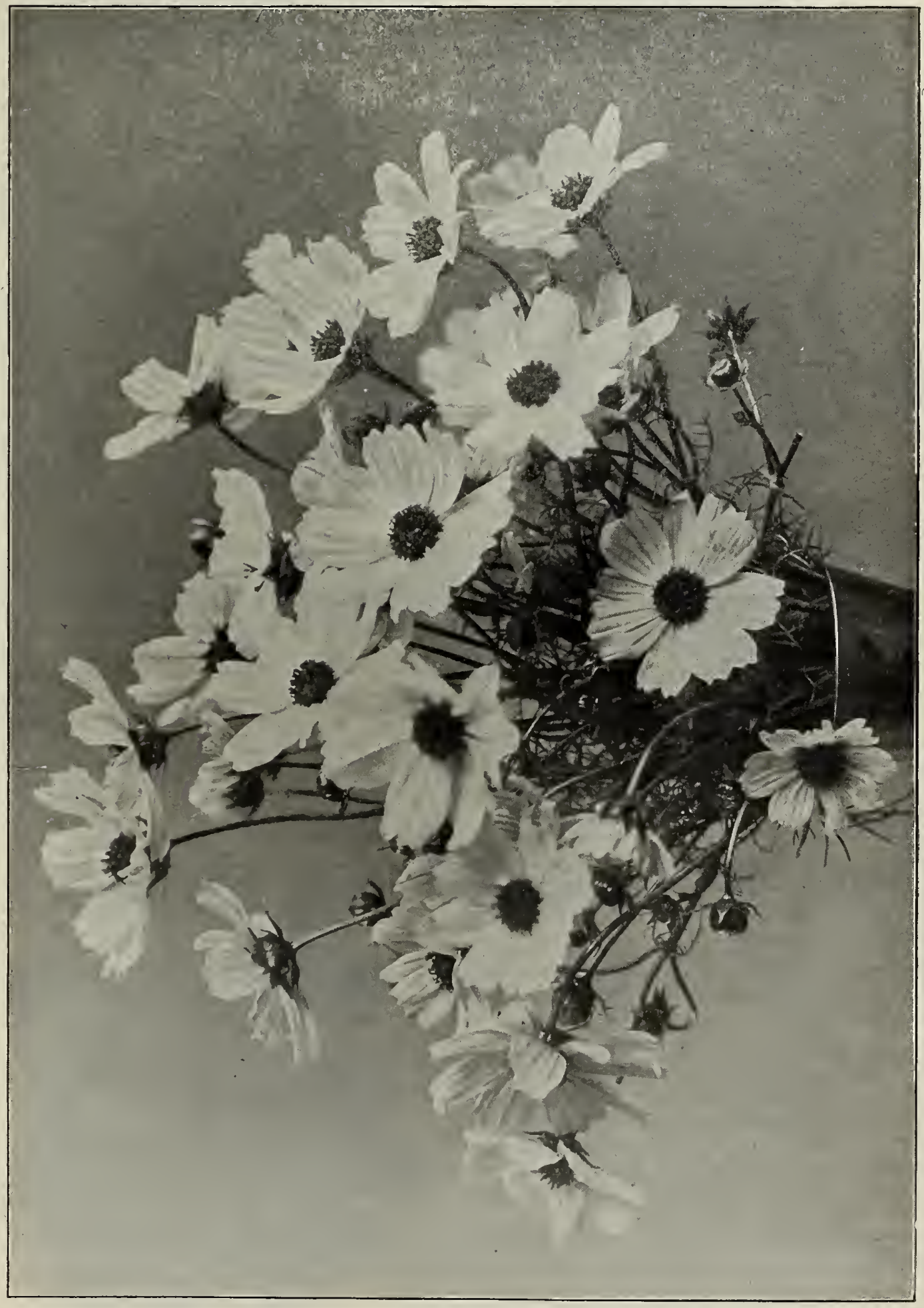




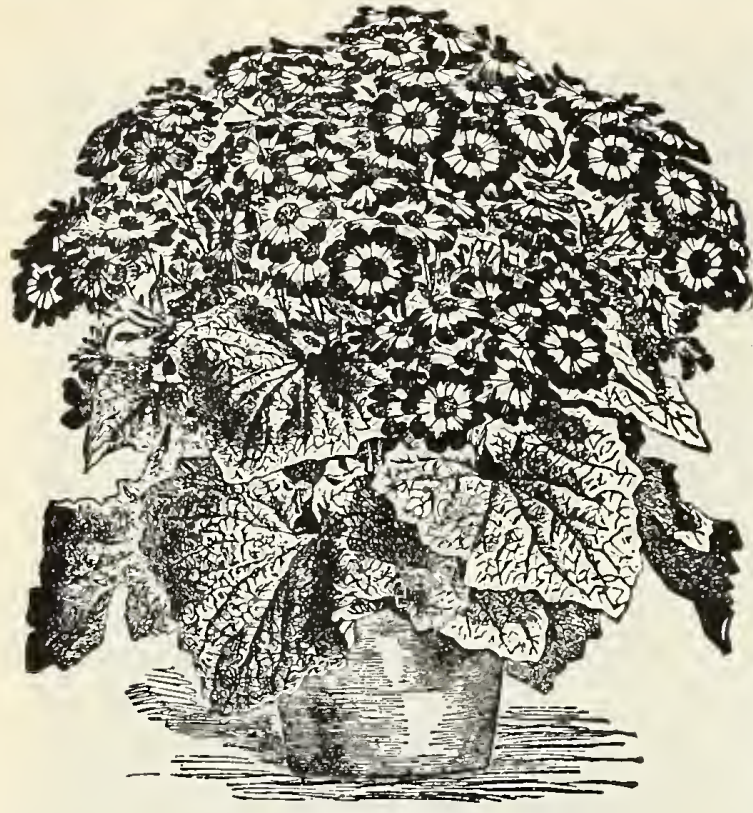

CINERARIA

CHRYSANTHEMUM MAXIMUM PERFECTION, OR OX-EYE DAISY. - A free-blooming hardy perennial, two feet high, is literally smothered with pure white, yellow-centered flowers. Splendid cut flower

Packet 5c.

Japanese Chrysanthemums.--If seed is sown in February or March the plants will bloom profusely next fall. Magnificent, enormous flowers in finest varieties. $\quad$ Per packet $10 \mathrm{c}$

CINERARIA. A A pery pretty gerus from one to three feet high. The flowers are of wondrous beauty, being brilliantly colored.

Hybrida Grandifiora.-(Large flowered).

Per packet $25 \mathrm{c}$

Bedding Cinerarias. -These are perensilvery foliage.

Maritima Candidissima. - White foliage; compact habit. Per packet $5 c$

COLEUS, - - Highly ornamental foliage ety of colors and shadings, indispensable for ribbon and carpet bedding, or as single specimens. Height, one to two feet.

Finest Hybrids.-In splendid mixture.

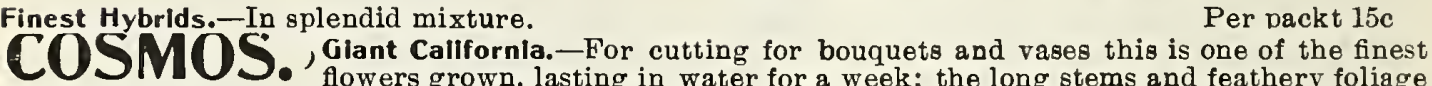
lend themselves flowers grown, lasting in water for a week; the long stems and feathery foliage idal form, are one mass of feathery, emerald green foliage, studded with mammoth flowers of white, pink or crimson, enlivening the garden long after more tender flowers have succumbed to early frost.

Glant Pink. Glant White.-The Pearl. Glant Crimson. Glant Mixed. Per packet $5 \mathrm{c}$ Early Flowering Cosmos.-Comes into bloom in July and continues to flower until cut down by severe irost. $\lambda^{\text {Mixed. }}$

Per packet 5c

Early Flowering "Dawn." Flowers pure white with a delicate touch of pink at the base of petals.

Dwarf Cosmos.. JaWh.

COSMOS, LADY LENOX. Gigantic Orchid-Flowering--A new orchid-flowering Cosmos having gigantic blooms of delightful sbell-pink color. A strong and vigorous grower, attaining height of 6 to 7 feet; the flowers may be cut with any length of stem up to $5 \mathrm{ft}$. Packer 10c.

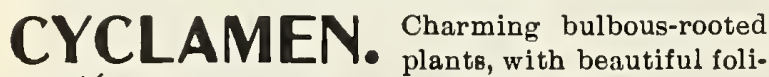
age 'ánd rich-colored orchid-like fragrant flowers; they require sandy loam.

Persicum Giganteum. - A great improvement over the old sorts; each flower measures from two to two and one half inches in length.

Mont Blanc.-Pure white. Dark Blood Red. Whlte with Carmine Eye. Rosa von Marienthal. -Daybreak pink. Magnificum.-White spotted and flaked red. Giant Flowered Cyclamen in finest mixture. Per packet $5 \mathrm{c}$

Daisy. (Perennial).-An old favorite which scarcely needs description. In bloom from April to June.

White, Deep Rose.

Per packet $10 \mathrm{c}$

Shasta Daisy.-A magnificent hardy perennial of the easiest culture. The seeds should be sown early. Bears immense flowers of purest white, on long wiry stems. Splendid cut flowers of good lasting qualities. Per packet $10 \mathrm{c}$

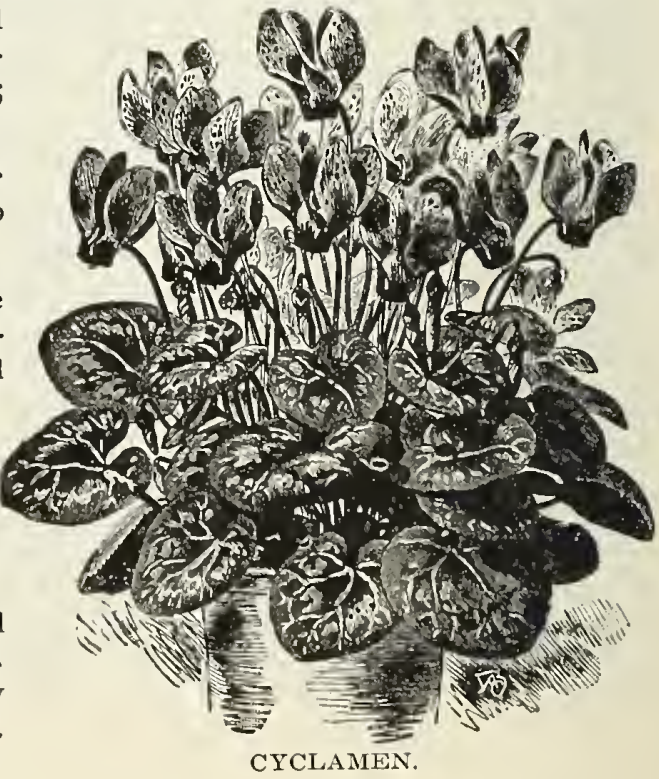




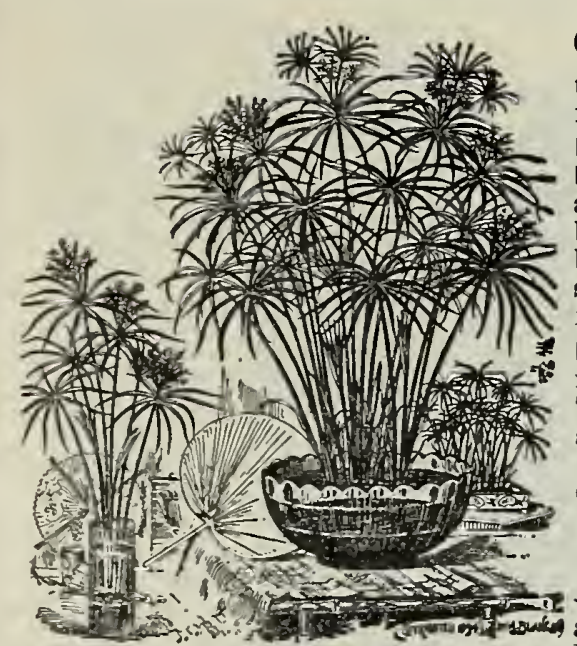

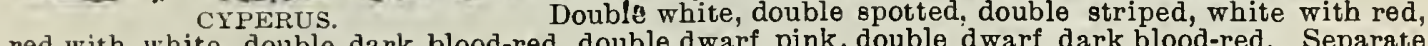

Cyperus, or Umbrella Plant. - Grows finely in water throwing up long stalks with narrow green leaves. Easily raised from seed. Per packet $5 \mathrm{c}$

Deiphinium.-(See Larkspur).

Digitais or Foxglove. - The tall flower stems of the Foxgloves are particularly handsome when seen growing among shrubbery, or in bold masses along walks or drives. Used as a background for lower plants they are also very fine. The long spikes are thickly strung with scores of showy, thimble-shaped flowers. Mixed.

Per packet $5 \mathrm{c}$

DRACAENA OR CLUB PALM.-Dracaenas are largely used for massing with other plants on the lawn, or as single specimens. They are of the easiest culture, fast growers and require no special care.

D. Indivisa.-Has narrow, long and pendulous leaves.Is particularly fine for hall or porch decoration. Per packet 5c

\section{DIANTHUS. Chinese Pinks.-}

-One of the most useful and desirable plants and for beauty and viriety of colors and markings cannot be surpassed. colors or mixed.

Per packet $5 \mathrm{c}$

HEDDEWIGi ANNUAL PINKS. - Their large flowers and brilliant colors make them very desirable for beds and borders.

Single and double varieties mixed.

Packet 5c

\section{Hardy Perennial Pinks}

Piumarius FI. Pi.-Double, large flowering Pheasant's Eye Pink, in various colors, with fringed edges. Packet $5 \mathrm{c}$

\section{EVERLASTING FLOWERS}

АммовІUM.-A favorite everlasting with white flowers; cut before fully open.

Packet 5c

GOMPHRENA GLOBOSA.-(Globe Amaranth). Large cloverlike heads of flowers.

Packet 5c

HELiCHRYSUM.-(Strawflower). Showy summer blooming plants, flowers large and double; in shades of white, yellow, crimson, etc.

Packet 5c

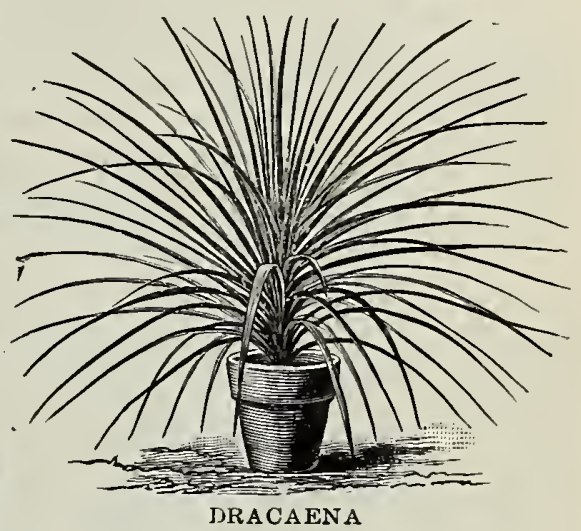

\section{ESCHSCHOLTZIA OR CALIFORNIA POPPY.}

New California Poppy._-“Rosy Morn."-A distinct new shade, producing flowers of a form hitherto unknown in the Eschscholtzia species. The rosy white petals are delicately channelled or fluted with tiny folds radiating from the center and richly adorned with a soft primrose yellow hue, enhancing the beauty of this charming flower.

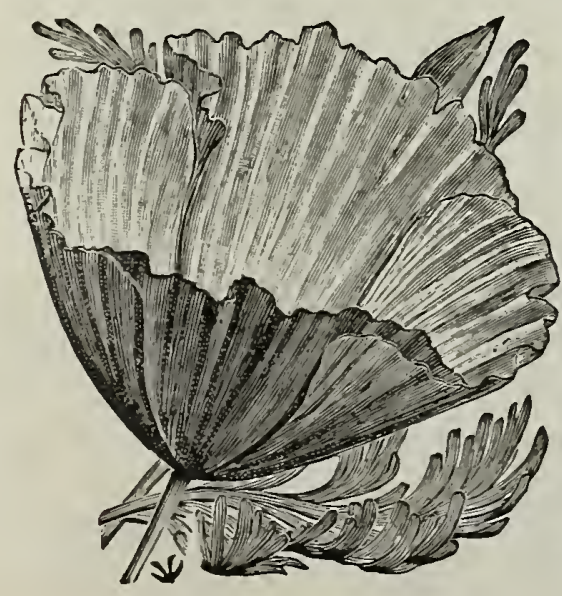

ROSY MORN.
Bush Eschscholtzia or Hunneman nia. - The plants grow into a shrubby bush, 2 feet high, and produce large cup-shaped flowers 3 inches across on stems 12 inches long. The color is of clear, bright yellow, the petals are broad and crinkled, like crushed satin. The flowers keep in water for two weeks.

Per packet 5c
Per packet $5 \mathrm{c}$

Dainty Queen.-A tender blush or pale coral-pink, slightly deeper towards the edges, with a ground work of delicate cream.

Per packet 5c

Golden West.-Bright yellow and orange, penciled and blotched. Packet $5 \mathrm{c}$ Mandarin.-Deep orange. Packet 5c Thorburni.-Decidedly distinct in coloring which might almost be described as being barbaric in splendor. The unopened buds on outer side of petals are of the richest deepest possible crimson toning down on the inner side to bright flame-color and molten-gold.

Per packet $10 \mathrm{c}$

Special Mixture.-Incluces all the new $\nabla$ arieties here described in addition to the older sorts, and is the most complete mixture offered. Per packet $5 \mathrm{c}$ 


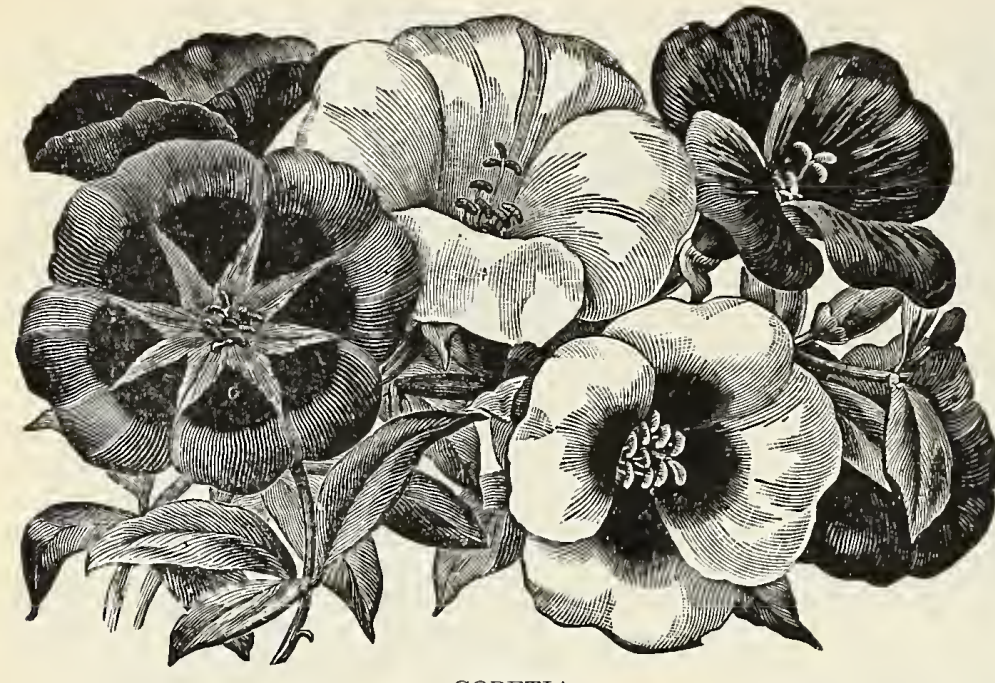

GODETIA

FEVERFEW.(Pyrethrum.) Matricaria.-Double white.

Packet 5c

Parthenifolium Aureum.-Low growing plant with yellow foliage, for edging. Packet 5c

\section{Forget-Me-Not}

Succeed best in a damp shaded situation, but will thrive in any garden soil.

Paiustris Semperflorens. - It blooms continuously from spring to fall. Packet 5c

Victoria.-Round little bushes completely covered with azure blue flowers. Packet 5c

\section{Four O'Clock.}

Shrublike plants with funnelshaped flowers of many colors. Packet 5c, ounce $15 \mathrm{c}$

Godetia.-Desirable g a r -

Packet 5c

den flowers; very free blooming; many colors; succeed anywhere.

CA A A D A A Eeedingly showy; produces large flowers of scarlet, white and yelSingle Mixed, Double Mixed, Single and Double Mixed.

Packet 5c

Gaillardia Grandiflora Maxima Kermesina.-Rich crimson center with a border of canary yellow. Immense flowers borne on long, stout stems. Among the showiest and most effective hardy perennial plants. If sown early they begin flowering in July, continuing a mass of bloom until frost; fine for cutting. They thrive in almost any position and soil.

Packet $10 \mathrm{c}$

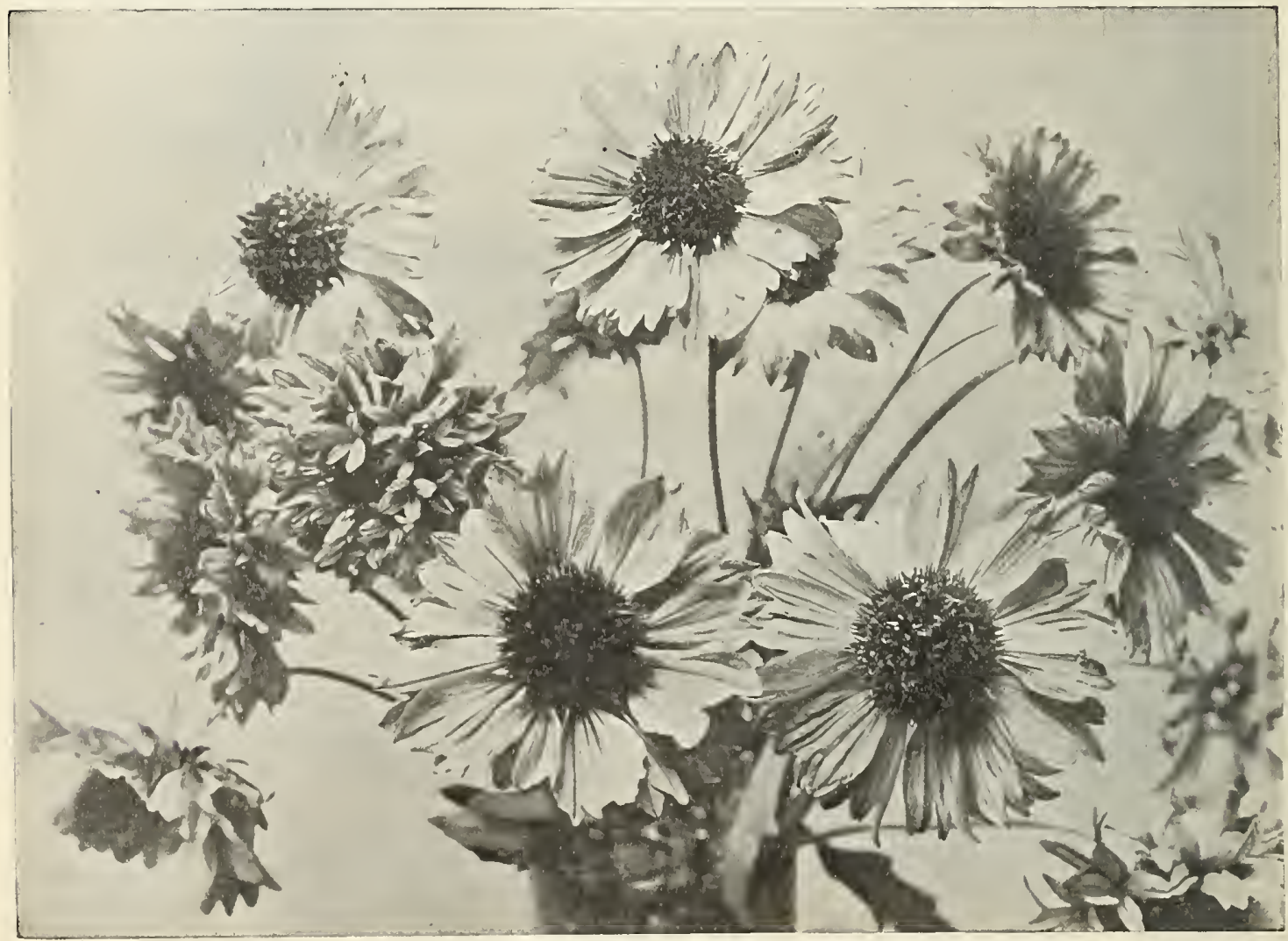

GAILLARDIA, Single and Double 
W. E. DALIWIG 34-Juneau Ave. MILWAUKEE है?

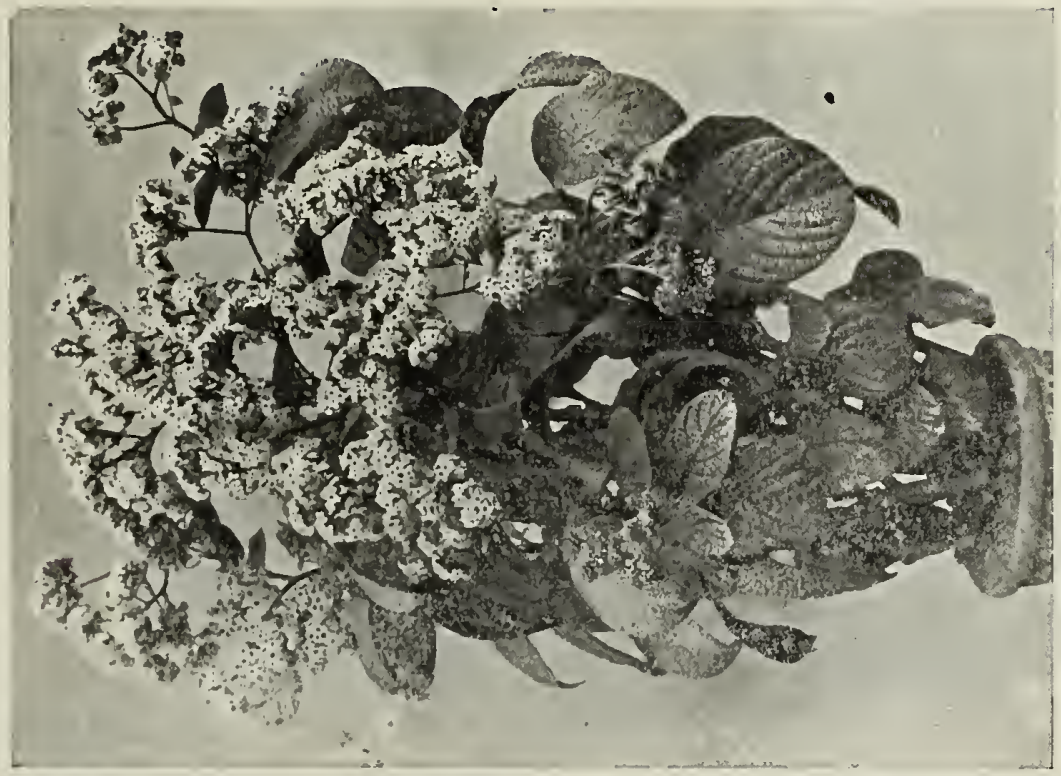

ำ

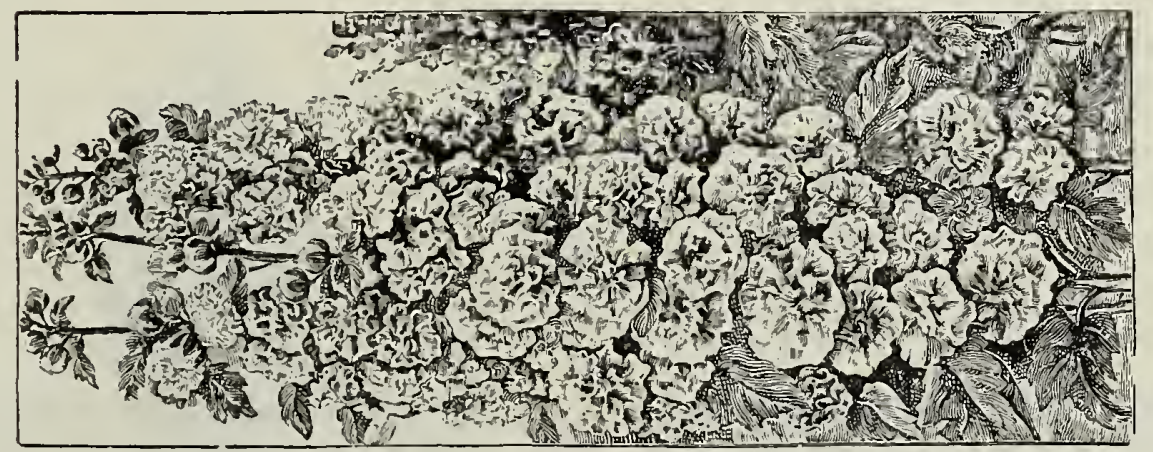

:

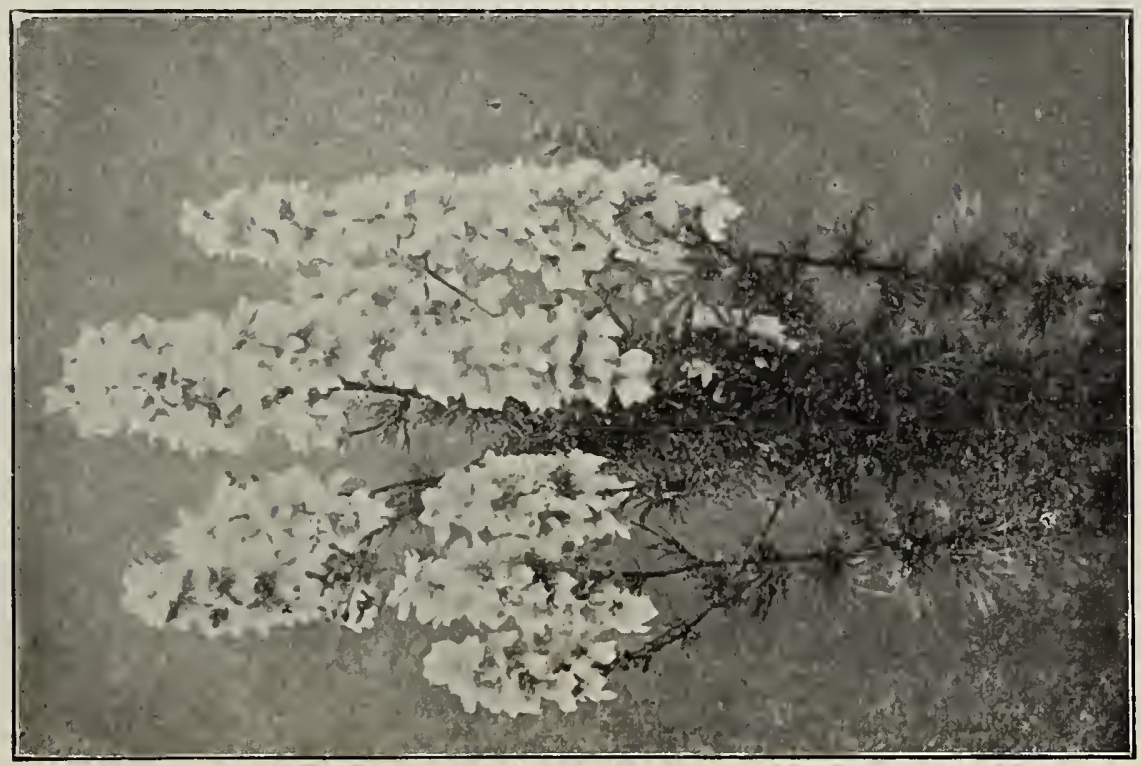

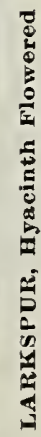


GYPSOPHILA. Elegans Alba Grandiflora.-Baby's Breath. Furnishes the loveliest material for all kinds of bouquets, the dainty, pure white flowers setting off bolder ones to advantage. Pkt. 5c HELIANTHUS. (SUNFLOWER.) Nanus fl. pl.-A dwarf variety, flowers very double, rich and golden yellow. Excellent cut flowers.

Packet 5c

Stella.-Well branched and bushy and attains a height of about three feet. Covered with finely formed flowers, about three inches across, of golden yellow color with black disc, and borne on long stems, which rise well above the foliage.

Packet $5 \mathrm{c}$

HIBISCUS. Crimson Eye.-Immense flowers of pure white with a large crimson eye. It blooms from seed the first year, sown in the open ground. A perennial, and lasts year after year. Packet 5c

HOLLYHOCK.

to six feet high.

Good Mixed. flowers. Pure white, yellow, scarlet, pink and chamoisrose.

Chater's Best Mixed.

Everblooming Annual Hollyhock.-Commences flowering in twelve weeks from seed, and continues until frost. The flowers are double, semi-double and single, and appear in all colors. Packet 10c

An old fashioned favorite, which should be sown in June or July to have flowering p'ants the next summer, or if sown in the house early in spring they will bloom the first year. Four

Packet 5c
HELOTROPE -Deliciously fragrant flowering plants, great favorites for pot culture or white flowers are continually borne. Finest mixed.
Per packet $5 \mathrm{c}$

ICE 'PLANT - Suitable for rock work, hanging baskets, etc., foliage thick and fleshy and of a ICE PLANT. frosted wax-like appearance.

Crystallinum.-Pink flowers.

Per packet 5c

Per packet $5 \mathrm{c}$.

LARKSPU R. Very showy plants with pretty flower in fall or early in spring.

Double Dwarf Hyacinth Flowered.-Finest Mixed; $1 \frac{1}{8}$ feet. Pkt 5c Perennial Larkspur. - These are valuable plants for the ing an ample supply of flowers.

New ChInese Larkspur.-A perennial plant of great beanty. The plants produce a great number of handsome blue flowers on wiry stems. Being a hardy perennial, the plants i.ucrease in size with age. Per packet 5c

Grandiflorum Flore Pleno.-Flowers large and double. A splendid cut-flower and ornamental plant. Many shades of color in finest mixture.

Per packet $5 \mathrm{e}$

Linum, Flowering Flax.- Scarlet; very attractive bedd-

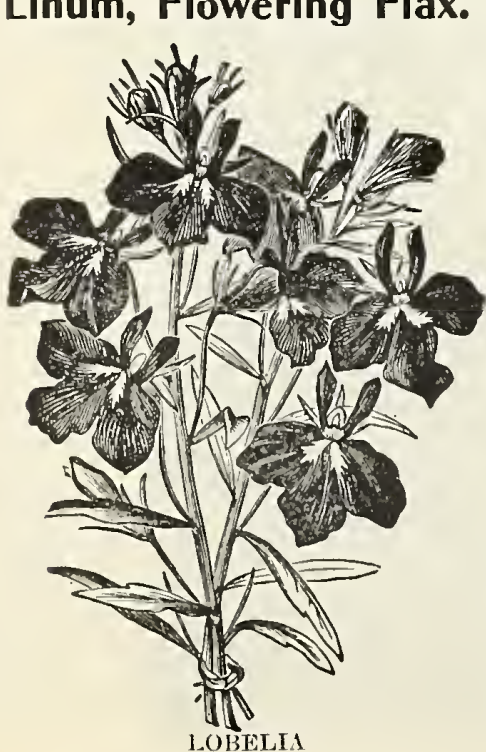

LOBELIA.

A dwarf plant with delicate, graceful foliage and pretty fine flowers. Of value chiefly for hanging baskets and border work.

Erlnus Gracllls.-Best for hanging baskets.

Per packet 5c

Erlnus Erecta Speclosa.-(Emperor William.)-Dark blue, white. eye. Dwarf.

Per packet 5c

CRYSTAL PALACE. (Compacta.)-Deep blue, dark foliage, fine bedder, 6 inches-

UP N (Sun Dials.) - Disirable bedding plants richly-colored pea-shaped flowers.

Dwarf Sorts.-Choice mixture.

Per packet 5c

MIMOSA Sensitlve Plant.-A most interesting little plant, MIMOSA. being so sensitive that a touch from the hand will instantly cause the leaves to fold up. When the hand is removed they will unfold again in a few moments. Small pink flowers.

Per packet $5 \mathrm{c}$

MIMUUS. Moshatus. (Musk Plant.) - The thin, delicate leaves emit a delicate musk odor. Per packet 5c 


\section{MARIGOLD}

The Marigolds are old favorite free flowering annuals of easy culture, and are particularly well adapted for mixed borders. Tall Sorts Mixed. Pkt. 5c CALENDULA. Pot Marigold

A hardy annual about a f o ot high. Excellent for bouquets and vased. Mixed. Packet 5c

\section{Mignonette}

A well known annual with spikes of deliciously fragrant flowers. Indispensable in all gardens.

G r a n d if $I$ o ra.-Largeflowered, sweet scented.

Packet 5c, ounce 10c

MACHET.-Undoubtedthe best sort for pot

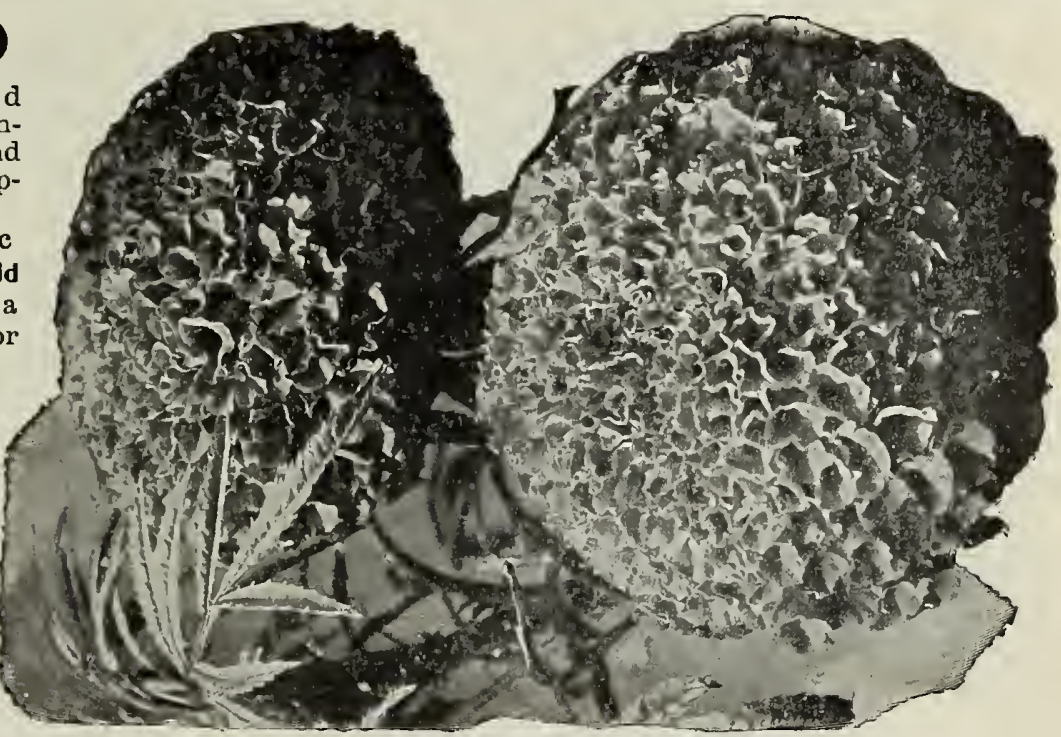
culture. Dwarf, vigorous

MARIGOLD flowers. GOLIATH.-Giant trusses of flowers of pure bright red color. Compact growth, rich green foliage. Excellent for cutting or pot plants. Packet 10c MACHET "RUBY."-A variety of Machet Mignonette showing the same compact habit of growth as the older sort, while its large, extremely thick flower spikes are of bright copper-scarlet color, such as has never yet been produced in any other existing Mignonette.

Packet 10c

NICOTIANA. Affinis.-An annual with sweet scented, pure white star-shaped flowers, three inches across, blooming continually. Packet 5c Sanderae Hybrids.-Large flowers borne in profusion. They come in eight colors, ranging from pure white to deep scarlet, some of the intermediate tints being of exquisite beauty. $\rightarrow$ Packet $5 c$ NIGELLA.- Free blooming plant, graceful foliage. Red, white, blue. Any color or mixed. Pkt. 5c Miss Jekyll.-Clearest cornflower blue, contrasting most charmingly with the fine foliage. Pkt. 5c

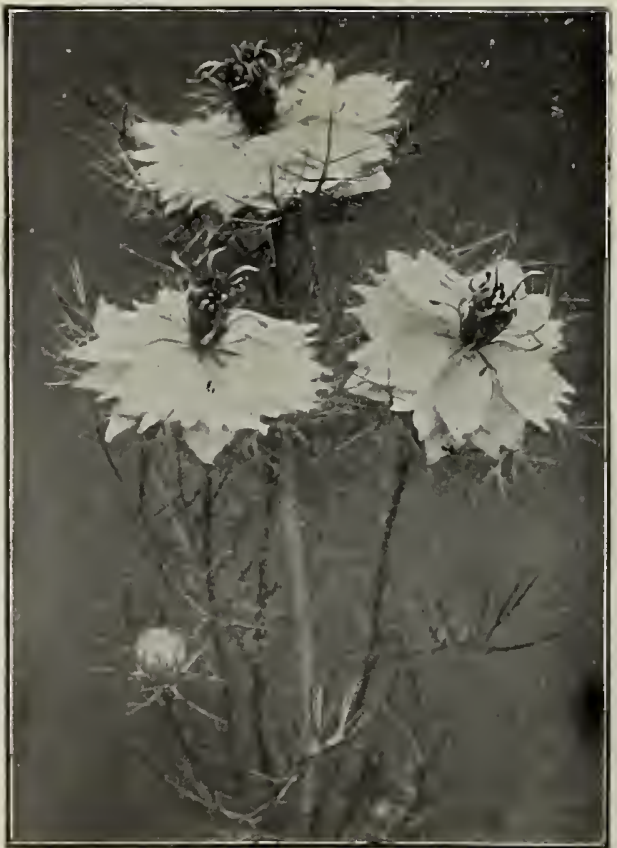

NIGELLA, Miss Jekyll

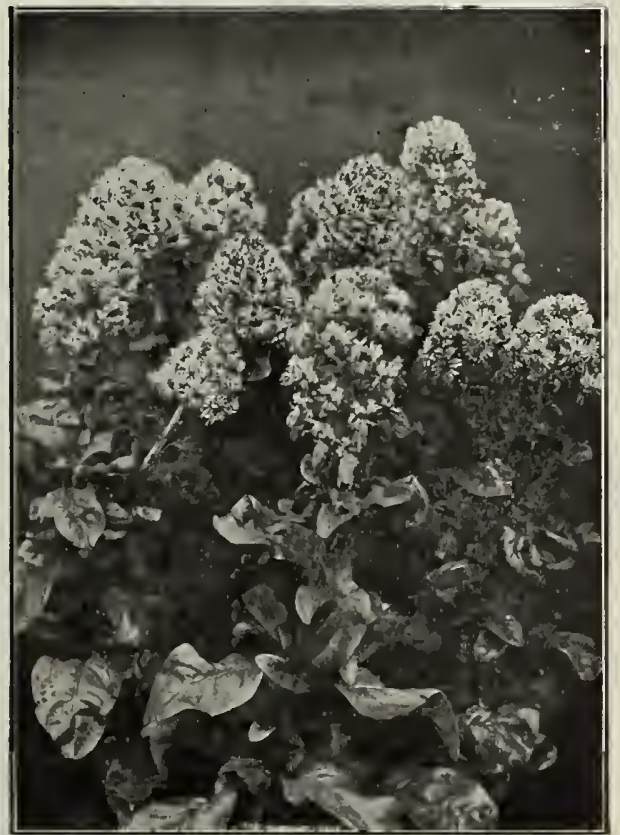

MIGNUNETTE 

soil, and remain in bloom a long time; stand heat and drought without the slightest effect. The seed, if picked young is an excellent subititute for capers

\section{Dwarf Varieties.}

Aurora.-Deep chrome yellow, the two lower petals blotched and veined carmine.

Atrococclneum.-Deep scarlet, verry pretty.

Beauty.-Canary, splashed scarlet.

Crystal Palace Gem.-Sulphur yellow with maroon spots.

Cattel's Crimson.-Deep crimson.

Dwarf Nasturtium "Chamaeleon."-This strain is remarkably dwarf. Its flowers present many attractive colors and markings and are carried well above the foliage. The same general description applies to this as well as to the tall variety.

Per packet $5 \mathrm{c}$, ounce $20 \mathrm{c}$
Empress of Indla.-Splendid variety, with very dark leaves and crimson flowers.

Golden King.-Brilliant yellow, dark foliage.

King Theodor.-Dark green foliage, flowers velvety, almost black.

KIng of Tom Thumbs.-Intense scarlet flowers and dark foliage.

Prince Henry.-Beautiful golden-yellow, spotted and marbled with brilliant scarlet, which in combination with the dark green foliage presents a striking appearance.

Pearl.-Creamy white.

Roseum.-Pink.

Spotted KIng.-Yellow splashed with brown; very handsome.

\section{Dallwig's Special Mixture of Dwarf Nasturtiums.}

All the above named sorts in even mixture, put up by ourselves; will furnish the most beautiful bed. Per packet $5 \mathrm{c}$, ounce $15 \mathrm{c}$, $\frac{1}{4}$ pound $40 \mathrm{c}$

Brilliant Fulgens.-Dark scarlet with dark green leaves.

Coccineum Multiflorum.-Scarlet.

Crown Prince of Prussia.-Brilliant dark blood red.

Flammulum Grandflorum.-Scarlet, splashed with yellow.

Tall Nasturtium "Chameleon." - It is unique in bearing Howers of quite distinct colorings on one and the same plant-some clear, deep crimson, others blotched on light grouna and others beautifully mottled. The tall variety, with its very large rich flowers in the greatest variety, is unsurpassed for training over fences and trellises, and blooms with the greatest freedom the entire season.

Per packet $5 c$, ounce $20 \mathrm{c}$

Hookerl.-Dark yellow, spotted brown.

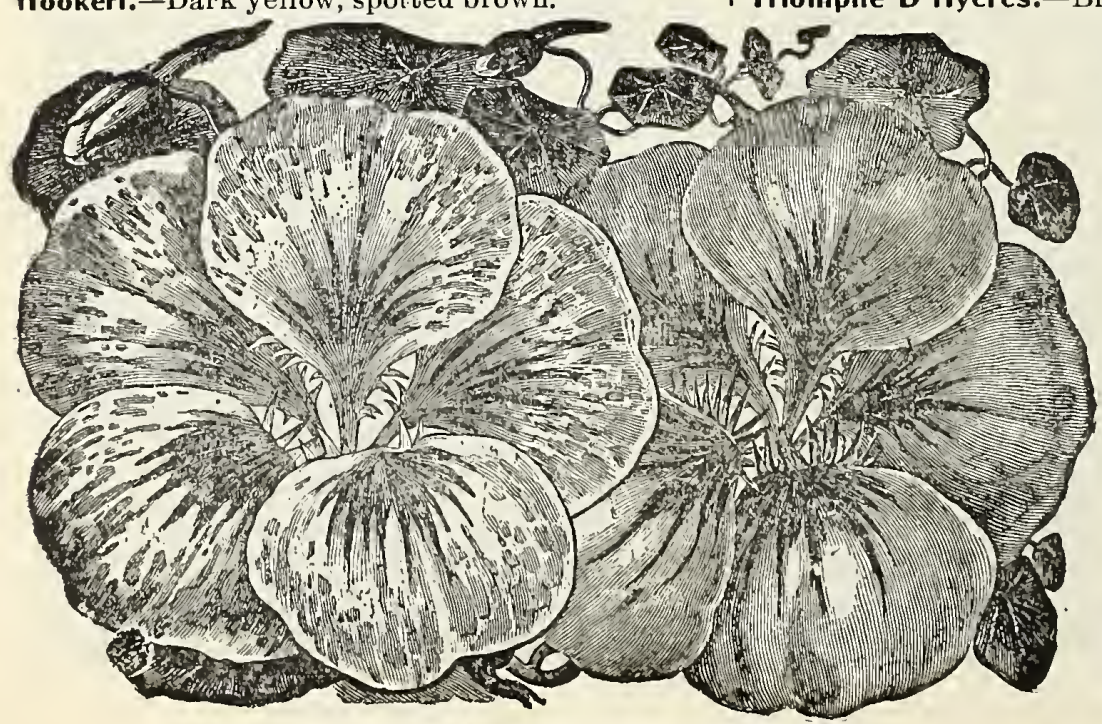

NASTURTIUM, MAD. GUNTHER'S HYBRIDS.
New Cllmblng Nasturtlum, Mad. Gunther's Hybrids. -For richness and variety of colors these new hybrids have no equals among Nasturtiums. There are shades of rose, salmon, brightest red, pale yellow, either as self-colors or spotted and striped. The foliage is mostly dark and eontrasts very effectively with the rich colors. They are climbers and free and continuous bloomers. It is impossible to describe all the different colors. It contains a great many colors that are not found in any other mixtures. Per packet $5 c$, ounce 150 King of Blacks. - Almost black.

Lucifer.-Deep scarlet with dark foliage.

Mercler Lacombe.-Reddish-brown.

Spitfire.-Bright red.

Sulphureum.-Sulphur-yellow.

Trlomphe D'Hyeres.-Bright scarlet.

Dallwig's Special Mixture of Tall Nasturtiums. - All the above varieties in best mixture. No better offered anywhere.

Pkt. 5c, oz. 15c, 遈 fo $40 \mathrm{c}$

\section{Christmas or}

\section{Celestial Pepper}

One of the very best introductions in berried plants. The plants are covered with bright colored cone-shaped fruit at Christmas.

\section{Packet $10 \mathrm{c}$}

SOLANUM. (Jerusalem Cherry).-Fine for pots Fruit about the size and color of cherry. Pkt. 5c 


\section{PANSIES, Dallwig's Mixture} While the Giant Pansies are favorites on account of immense size of their flowers, our Mixture of Large Flowering Pansies excels in its endless variety of colors.

Packet $5 \mathrm{c}$, tounce $40 \mathrm{c}$, ounce $\$ 1.25$

\section{GIANT PANSY.}

The term "Grant Pansies" does not adequately describe these new strains, for aside from the enormous size which gives them their name, their colorings are simply superb and their form and substance perfect.

Giant Trimardeau Improved.- A greatly strain. Flowers of immense size and larger variety of colors than are generally offered under that name. We offer the following colors:-

Glant Emperor WIlliam.-Color splendid ultra-marine blue with purple-violet eye.

Glent Adonls. - Magnificent light blue with white centre.

Glant Auricula Colors.-Of especially good substance and beautiful shadings of copper and mahogany colors.

Giant Yellow with dark eenter. Glant Striped.

Glant White Ground, Marbled. Giant KIng of Blacks.

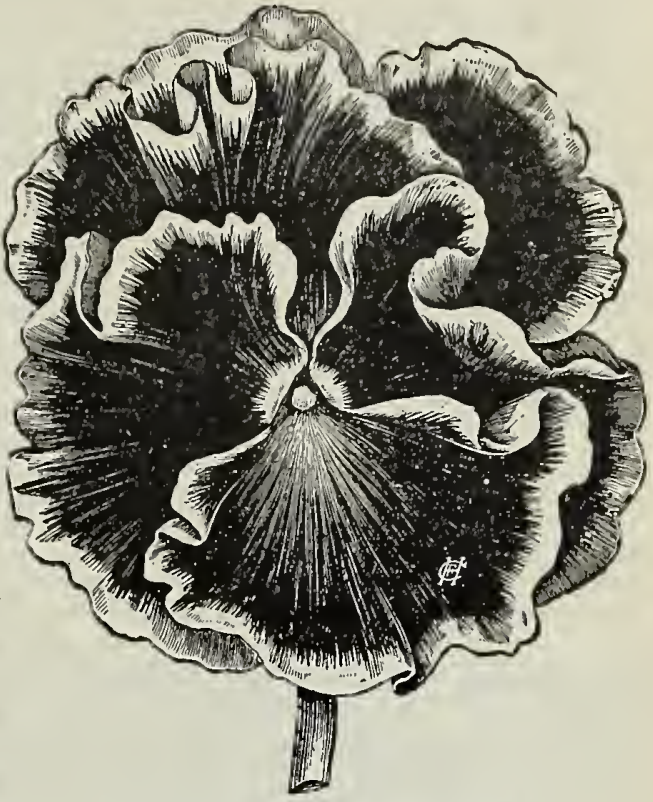

NEW PANSY "MASTERPIECE."

Glant Golden Gem.-Clear golden yellow. Glant Snow Queen.-Pure white.

Giant White, Spotted Center.

Glant Vlolet Blue.

GIANT TRIMARDEAU IN BEST MIXTURE. All the above colors and shades.

Per packet $10 \mathrm{c}$, ounce $\$ 2.50$

GIANT ODIER. Flowers large, spotted on each petal. Splendid mixture.

Per packet $10 \mathrm{c}$, oance $\$ 4.00$.

GIANT CASSIER.-This is a very fine mixture of Pansies with three or five blotches on rich backgrounds. The flowers are very large, round and borne on stiff stalks emerging from bnshy, comnact plants. This mixture contains a great many red shades.

Per packet $10 \mathrm{c}$, ounce $\$ 4.00$

GIANT BUGNOT.-Flowers of enormous size and the most circular form; the petals are of great substance and velvety appearance, each one bearing a large, deeply colored blotch that runs out in delicate veins to the edge; the shadings are wonderfully rich and comprise tints of red, bronze and reddish brown that are not to be found in any other mixture.

Per packet $10 \mathrm{c}$, ounce $\$ 5.0 \mathrm{n}$

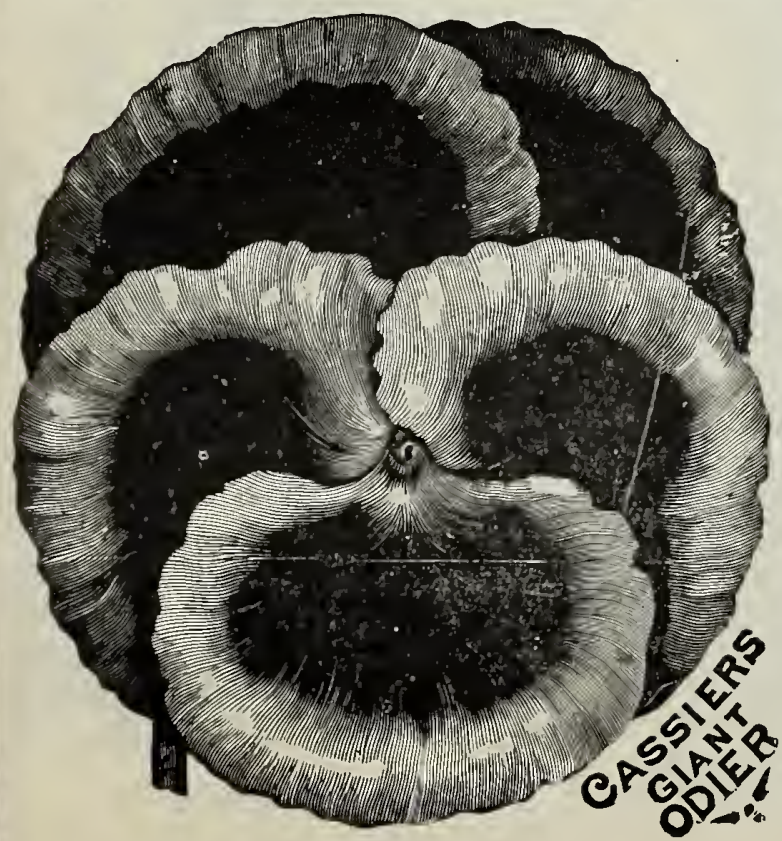

"Triumph of the Giants". - Th he of this novelty, which in every respect surpasses anything heretofore offered in Pansies, distinguish themselves by their robust, compact growth and enormous, five-spotted, perfectly round flowers of unusual substance. In most of the flowers the border of each petal is conspicuously undulated and curled. The beauty, brilliancy and richness of color are most striking; many rare and new tones of red and brown will be noted.

Per packet $15 \mathrm{c}$

"Masterpiece" "-The margin of each petal as conspicuously undulThe flowers are of extremely large size, borne well above the foliage on strong stems.

Per packet $15 \mathrm{c}$

GIANT HORTENSIA. - New magnificent pink. Color of Hydrangia. Per packet 15c

\section{Dallwig's Giant Pansy Mixture.}

This mixture comprises all of the above strains and varieties of Giant Fansies in most satisfactory proportion of colors.

Per packet 15c, 2 for $25 \mathrm{c}$, ounce $\$ 3.50$ 
PETUNIA, For freedom of hloom, varure and effectiveness these rank with the Asters, Phlox and Verbenas. With only little care, Petunias will produce their handsome, sweet scented flowers in delicate and gorgeous colors throughout the whole summer.

Finest Hybrids, Mixed.- Packet 5c, $\frac{1}{8}$ ounce $15 \mathrm{c}$ Large Flowering Single Fringed.- Packet $15 \mathrm{c}$ Large Flowering Double Fringed.- Packet 20c Star Petunia.- Ground color a dark crimson maroon with violet veinings. The star is a light bluepink, deepening towards the margins. Packet 5c

D. O. Invaluable for bedding, masses which vary from the purest white to the deepest blood red. There is no annual which can compare for beauty, duration of bloom, brilliancy of color and usefulness to the Phlox.

PHLOX DRUMMONDI.-This mixture will delight and astonish all with its extensive variety of colors. A bed of Phlox Drummondi in assorted colors makes a grand display all summer.

Packet 5c, $\frac{1}{4}$ ounce 15c, ounce 50c

\section{Phlox Drummondi Grandiflora.}

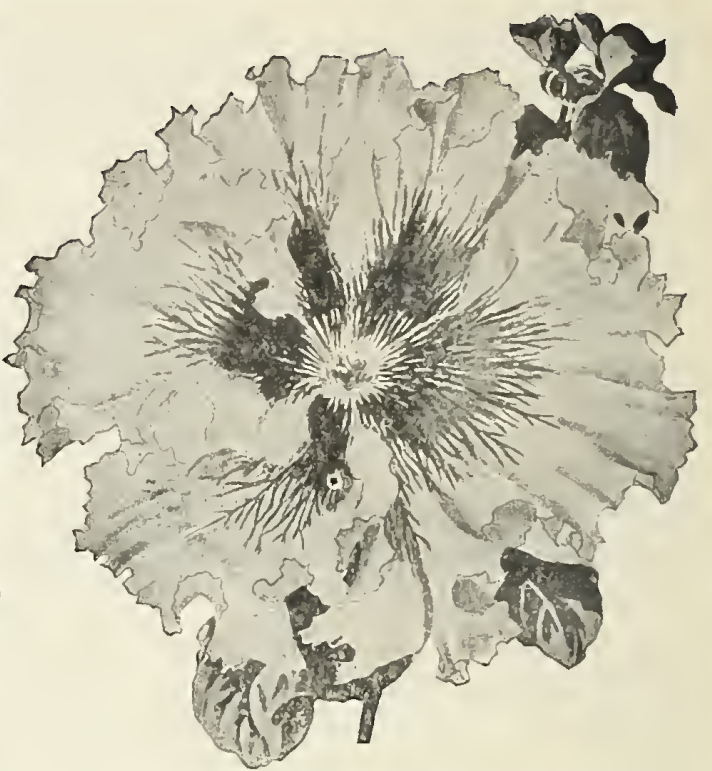

Large-Flowering Phlox.-Produce flowcrs twice the LARGE FLOWERING SINGLE FRINGED PETUNIA. size of the common, with the most brilliant colors imaginable.

Grandiflora Alba.--Large flowering pure white.

Grandiflora Coccinea.-Larye flowering bright red.

Grandiflora Atropurpurea.--Large flowering deep red.

Finest Large Flowering Mixed.

Packet 5c

Packet 5c

Packet 5c

Star of Quedlinburg.-The center petals, which are five in number, are elongated to four or five times the length of the lateral ones. Distinct and starlike.

Dwarf Phlox. (Phlox Drummondi Nana Compacta).-These are much superior to the other Phloxes for ribbon bedding or borders. The plants grow very symmetrical in neat little bushes, about eight

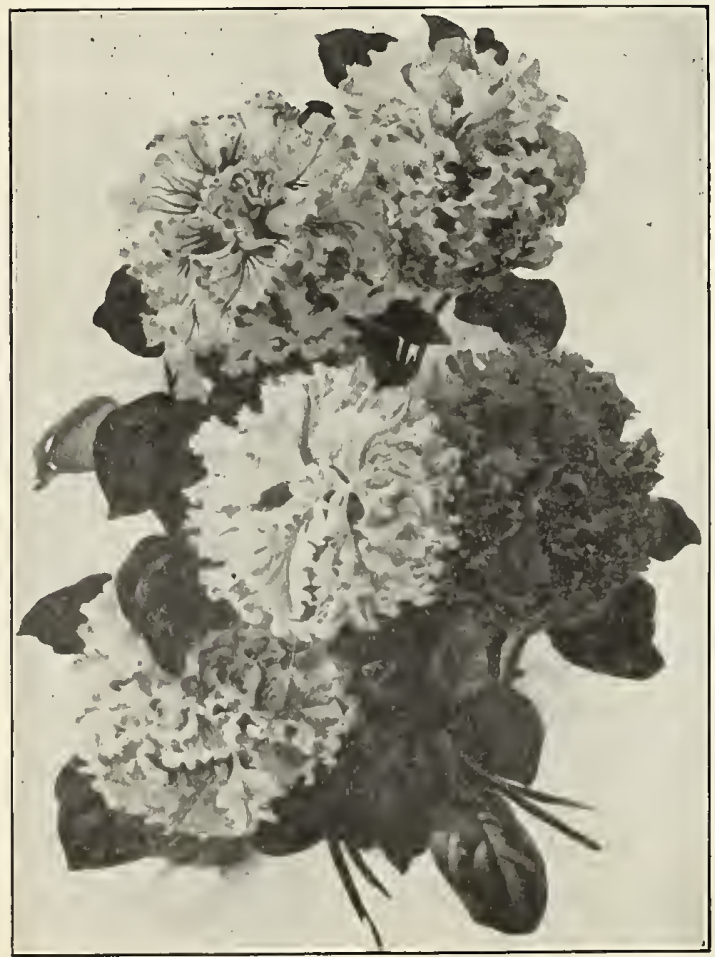

PETUNia, Large Double Fringed inches high.

Packet 5c

Hardy Phlox.-Perfectly hardy, need no protection; grow in any soil, but succeed best in deep rich, moist ground. Very showy, handsome trusses of flowers last a long time. Best large flowering, newest varieties mixed. Packet 5c

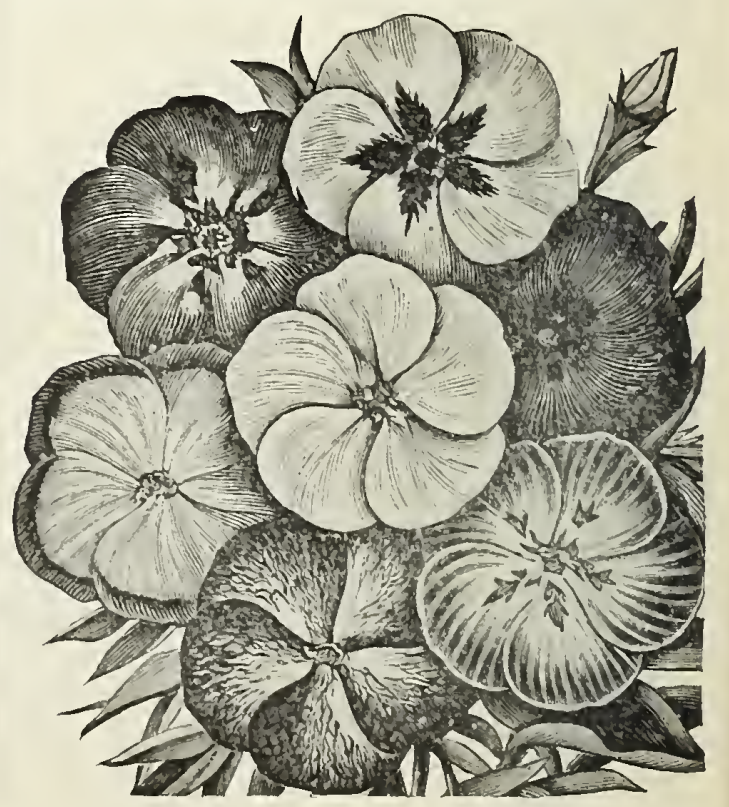

Phlox Drummondl Grandiflora 


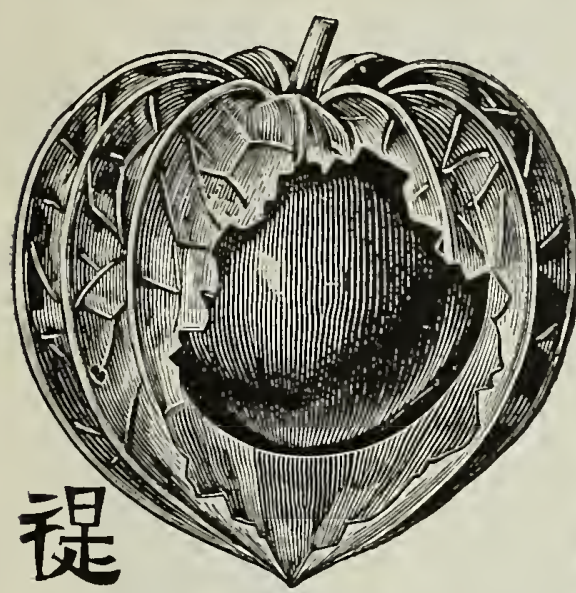

PHYSALIS

PHYSALIS. (Chinese Lantern Plant.) Franchet 1 . Winter Cherry, forming dense bushes about 2 feet high, producing freely its bright orange-scarlet, lantern-like fruits, which are said to be superior to the Winter Cherry for cooking, preserving or eating raw, but it is as an ornamental plant that we think it will be most appreciated. A perennial, blooming year after year. (See cut). DDD Poppies are steadily regaining their PODDO strange when we consider how many new varieties have been introduced and how large a list of desirable kinds we now offer. Their brilliant dazzling colorings and wonderful variety make a very effective display in the garden or for cut flowers.

\section{SINGLE.}

MephIsto.-Striking scarlet color beautifully spotted with dark violet blotches.

Per packet $5 \mathrm{c}$

Shirley.-The colors of this Poppy are so varied that scarcely two will be found alike, ranging from white, rose and carmine to bright sparkling crimson.

Per packet $5 \mathrm{c}$

Miss Sherwood. - Bears profusely large single Howers of a satiny white, upper half of corolla being a silky chamois rose; a combination of rare delicacy.

Per packet 5c

Danebrog.-Fine single poppy, flowers scarlet, with white spot on the base of the petals. Packet $5 \mathrm{c}$

DOUBLE.

Paeony Flowered Double. - Flowers in size and color equal to Paeonies.

Double Paeony Flowered.-Scarlet. Packet 5c " " $\quad$ " $\quad$-Pink. Packet 5c

Mikado.-Pure white at the bsck, the fringed edges brilliant scarlet.

\section{HARDY POPPIES.}

Oriental Poppy.-Unequalled in brilliancy of colors. Flowers very large and range from soft flesh and rose to the most brilliant, dazzling scarlet and richest maroon purple. Perfectly hardy. Mixed. (See plate XI.) Per packet $5 \mathrm{c}$

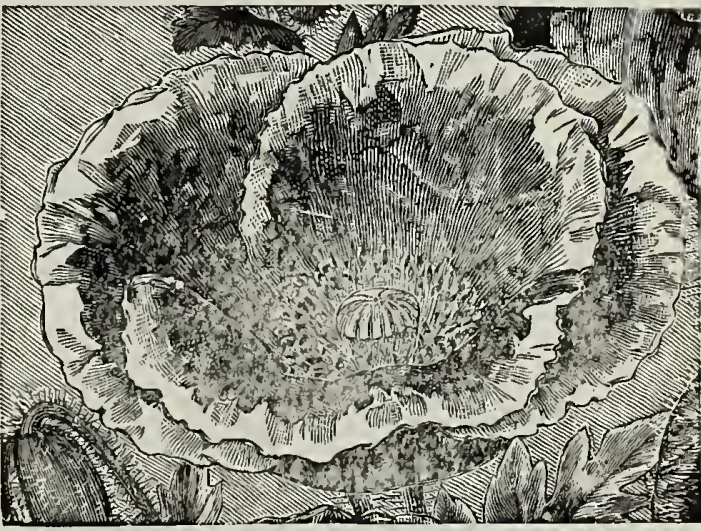
Oriental Poppy.-Scarlet. Per packet 5c

Iceland Poppy. (Nudicaule.)-These Poppies are perfectly nardy and produce in endless profusion flowers which are most useful for cuting. They are of a very graceful, neat habit with slender stalks about 12 inches in height, surmounted by yellow, white, or orangescarlet flowers.

Per packet 5c

Dallwig's Speclal Poppy Mixture. - Comprises all the annual Poppies described above, making a splendid color display.

Santa Rosa Poppy. - A new strain of Shirley Poppies, originated and improved by Luther Burbank. Combines all the delicate beauty in color of the original Shirley and Shirley types, and with these the whole flower in all of its petals is beautifully crim ped. Packet $5 \mathrm{c}$.

Per packet 5c

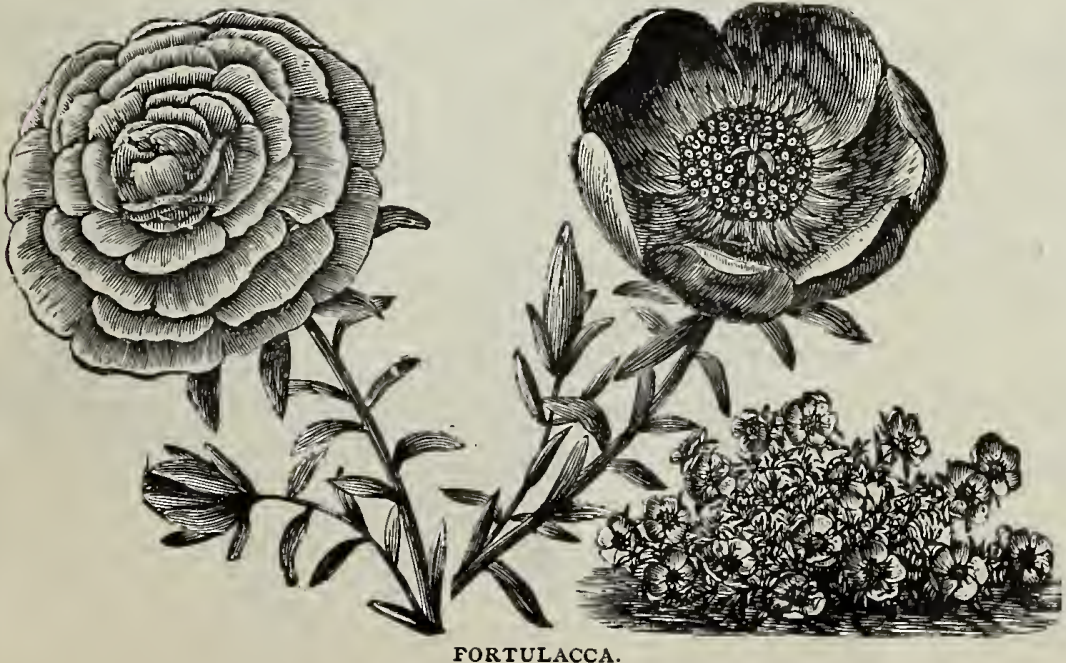

See also Eschscholtzla or Callfornia Poppy, page, $\{53$

PORTULACA.(Moss Rose.)-For brilliant, beautiful and delicate flowers these lovely plants have no equal. Grows in a dry hot situation, where any other plant would soon die.

Single Mixed.Ounce 35c, packet 5c

Double Mixed.-

Per packet 100 


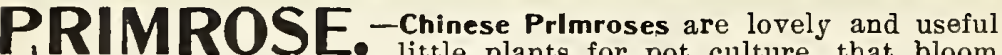
L little plants for pot culture, that bloom very fine light soil. Pot into small pots, shift two or three times during the summer and keep in a cool, moist, shady place and success is sure. \& Our Primula seed is from the best European growers. We furnish florists largely with our strain and it gives satisfaction to everybody.

Single, large flowering fringed Chinese.

Per packet $15 \mathrm{c}$

Primuia Obconica, New Large Fiowering.-An everblooming Primrose which blooms during eight months of the year. Flowers borne on stems about nine inches high. If sown in March will bloom in June. It is one of the most useful pot plants for the window, and if planted out
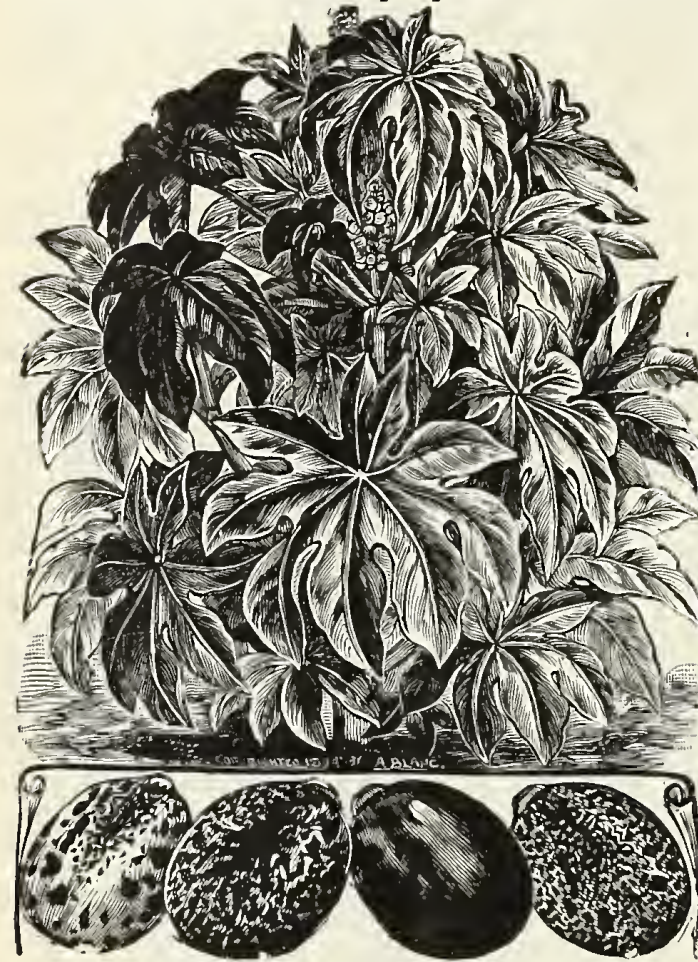

RICINUS-Plant and Seed.

Zanzibariensis.-Ten to fifteen feet high and the leaves measure about thirty inches across and in different plants range from bright green with green stems to deep bronze with dark red stems, all having a brilliant luster.

Per packet $5 \mathrm{c}$

\section{GIANT SNAPDRAGON}

The flowers of this strain are of very large size, are very fragrant and are produced on immense long spikes, making them particularly valuable as cut flowers. They are easily raised from seed. Spring seedlings bloom by midsummer, and if flowers are cut freely, continue till Fall. Album. White.

Crescia. Deep scarlet.

Luteum. Yellow.

Queen Victoria. Large pure white.

Roseum. Pink.

Dainty Queen. Chamois-rose with bright yellow lip.

Daphne. Carmine-rose, white throat, the lower lip touched with white.

Best Mixed.

Packet 5c, tounce 30c makes a very attractive border plant. White, lilac or mixed.

Per packet 10c

“B A B Y PR IM. ROSE." (Primula Forbesi. - The illustration $\mathrm{show}$ s the great freedom with which it bears its flowers. They are of
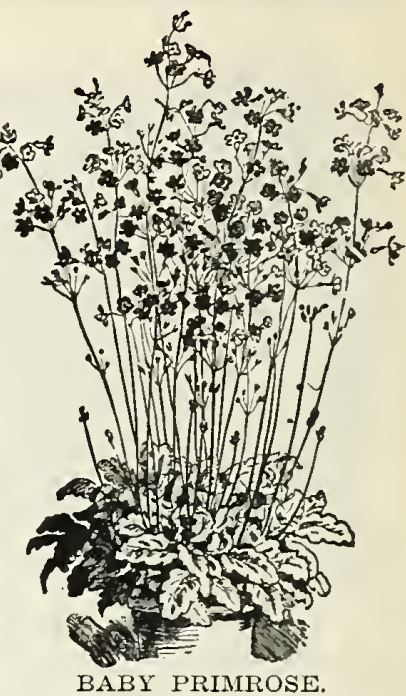

a delicate rose color and they keep fresh for a long time after cutting. The seed comes up very readily, and the little plants throw up tiny flower stalks when only a few weeks old. These, however, should be pinched off, and the plants kept growing for some weeks when the flowers may be allowed to develop, and from then on they produce their sprays of beautiful flowers in seemingly never ending profusion. Per packet 10c

PQPUC Known as "Castor "Palma Christi"; a rapid growing foliage plant with large palm-like leaves, much used for subtropical effect on the lawn, or for center beds of foliage plants.

Borboniensis.-Fifteen feet, immense green foliage. $\quad$ Per packet $5 \mathrm{c}$

Sanguineus. - A distinct variety with beautiful brownish red foliage and bright seed-pods; very effective. Height, six feet.

Per packet $5 c$

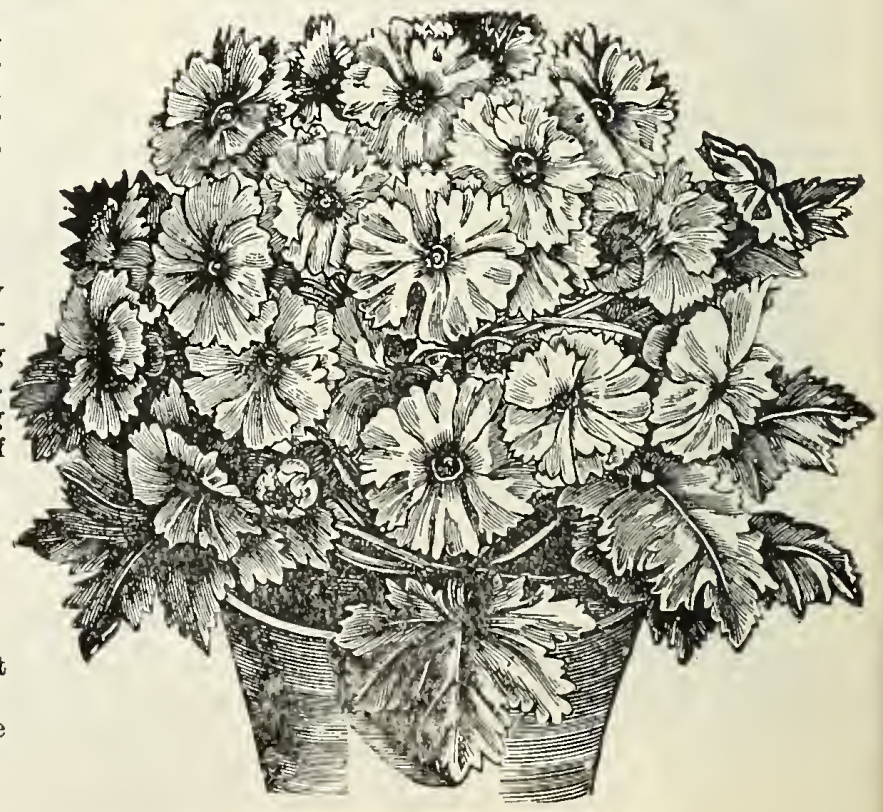

CHINESE FRINGED PRIMROSE. 

Memorandum Sheet 


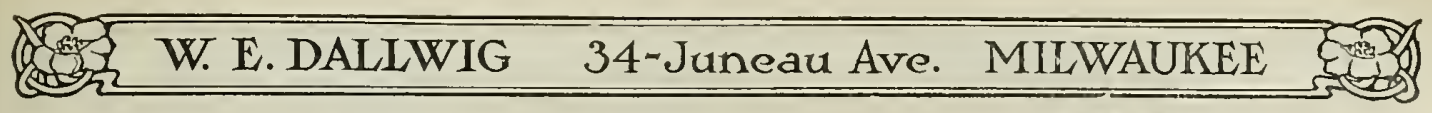

\section{SALPIGLOSSIS. -The shape and size} what similar to the Petunia and embraces a great variety of rich colors.
Fine Mixed, from named sorts.-
Per packet 5c

SA VA. (Flowering Sage.)-It is one of the most poses, if planted either singly, in groups, or with other plants. The flowers are of the most brilliant, dazzling scarlet, produced in endless profusion and until late in the fall.

Saivla Splendens,-Bright scarlet; large flowering; very
fine.

Salvia, Clara Bedman. (Bonfire.) - Handsome globular bushes about 2 feet high by one foot in diameter. The spikes grow errect and stand clear above the foliage, completely covering the plant and are of a most brilliant dazzling scarlet.

Per packet 100
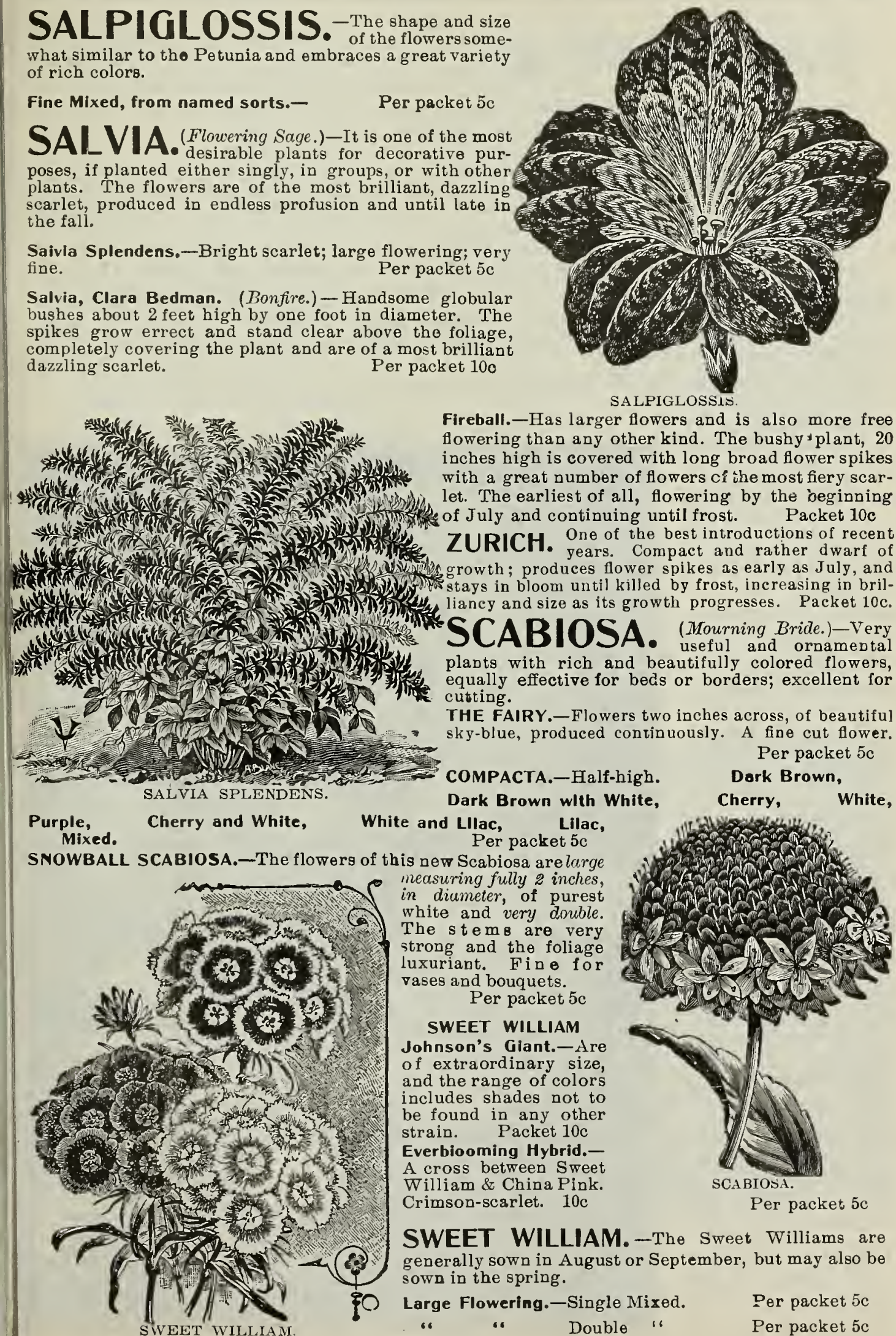

Fireball.-Has larger flowers and is also more free flowering than any other kind. The bushy 'plant, 20 inches high is covered with long broad flower spikes with a great number of flowers cf the most fiery scarlet. The earliest of all, flowering by the beginning of July and continuing until frost. Packet 10c ZURICH. One of the best introductions of recent ZURICH. years. Compact and rather dwarf of growth; produces flower spikes as early as July, and stays in bloom until killed by frost, increasing in brilliancy and size as its growth progresses. Packet $10 \mathrm{c}$.

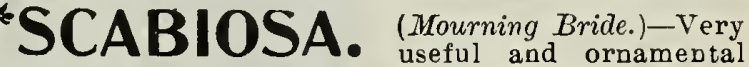
plants with rich and beautifully colored flowers, equally effective for beds or borders; excellent for cutting.

THE FAIRY.-Flowers two inches across, of beautiful sky-blue, produced continuously. A fine cut flower,

COMPACTA,-Half-high.

Per packet $5 \mathrm{c}$

Dark Brown with White, Cherry, White,

Mixed. Lilac,
Per packet $5 \mathrm{c}$

The flowers of this new Scabiosa are large measuring fully $\mathscr{Z}$ inches, in diumeter, of purest white and very double. The stem are very strong and the foliage luxuriant. Fine for vases and bouquets. Per packet 5c

SWEET WILLIAM Johnson's Giant.-Are of extraordinary size, and the range of colors includes shades not to be found in any other strain. Packet $10 \mathrm{c}$

Everbiooming Hybrid.A cross between Sweet William \& China Pink. Crimson-scarlet. $10 \mathrm{c}$

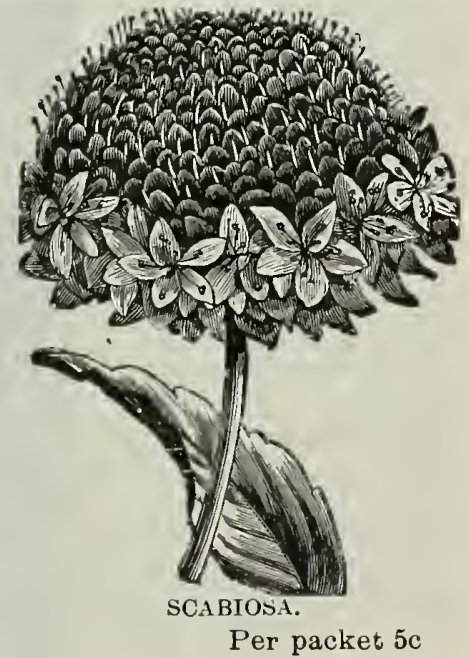

SWEET WILLIAM. -The Sweet Williams are generally sown in August or September, but may also be sown in the spring.

Large Flowering.-Single Mixed.

Per packet 5c

“ " Double "

Per packet 5c 


\section{SWEET PEAS. \\ Everyone who Cultivates Flowers Should Plant Sweet Peas. Our List Includes all of the Best Varleties Both Old and New.}

FOREMOST IN EASE OF CULTURE. MOST VARIED IN

\section{BOUNTEOUS TINTS. FRAGRANT AS ANY FLOWER.}

The Sweet Pea is one of the most popular flowers, and numbers thousands of skilled cultivators among its enthusiastic admirers. Early in spring make a trench 6 inches deep in rich, mellow, but not light soil. When about 5 inches high, furnish some support for the vines. Keep flowers picked. The "Spencer" Type. Has truly enormous flowers, and can only be appropriately described as "Orchid-flowered." The outer edges of the standard and wings are beautifully waved. Apple Blossom.- Shaded deep pink and soft rose on white Asta Ohn.-Charming soft lavender, suffused with mauve

Packet 5c, ounce 20c, t pound 60c Blanche Ferry.-Pink and white.

Packet 5c, ounce $30 \mathrm{c}$, $\frac{1}{4}$ pound $\$ 1.00$ Packet $10 \mathrm{c}$, ounce $50 \mathrm{c}$, $\frac{1}{4}$ pound $\$ 1.50$ Countess Spencer.-Soft rose-pink, shading a little deeper at the edges. Pkt. 5c, oz. 15c, $\frac{1}{4} \mathrm{tb} 40 \mathrm{c}$ Countess Spencer Mybrids.-A mixture of Spencer seedlings. Packet $5 \mathrm{c}$, ounce $15 \mathrm{c}$, 六 pound $30 \mathrm{c}$ E. J. Deal. - Mammoth white with well defined edge of carmine. Packet $10 \mathrm{c}$, ounce $60 \mathrm{c}$, t fo $\$ 2.00$ Etta Dyke.-Exquisite pure white. King Edward.-Gigantic, wavy flowers; deep rich carmine-scarlet. Packet 5c, ounce $30 \mathrm{c}, \$ 1 t$, $\$ 1.00$ Othello.-Deep rich maroon. $\quad$ Packet 10c, ounce 35c, $1 / 4$ pound $\$ 1.25$

Primrose Spencer.-A pronounced primrose or creamy yellow.

Packet 5c, ounce $15 \mathrm{c}$ Mrs. Roulzahn Spencer. -Beautiful color; buff or a pricot ground, suffused and flushed delicate pink, deepening towards the edges.

Packet 10c,

White Spencer.-Pure white, large, crinkled and fluted.

Packet 5c, ounce $15 \mathrm{c}$

Mixture above Spencers Pkt. 10c, oz. 20c, 卉形 60c

\section{"Unwin" Type.}

Although of distinct origin, these resemble the Countess Spencer; flut. ed and waved.

Frank Dolby.-L o vely light lavender, wavy. Gladys Unwln.-Beautiful light pink; crinkled. Helen Pierce.-Gloxinia flowered; bright blue on white.

John Ingman.-Orchidflowered; salmon-rose. Nora Unwin.-B e a u tifully waved or fluted. Very large pure white. Any variety: Packet 5c, oz. $10 \mathrm{c}, \frac{1}{4}+1 \mathrm{~b} 25 \mathrm{c}$, it $75 \mathrm{c}$

\section{Standard Sorts.}

Agnes Johnston.--Rose pink, shaded cream.

Aurora.-White, flaked orange-salmon.

Blanche Burpee.-Pure white; very large.

Brilliant.-Bright scarlet Captain of the Blues.Purplish mauve.

Countess of Radnor.Pure delicate lavender. Dalnty. - White, daintiIy edged pink.

Dorothy Eckford.-Pure white, giant flower.

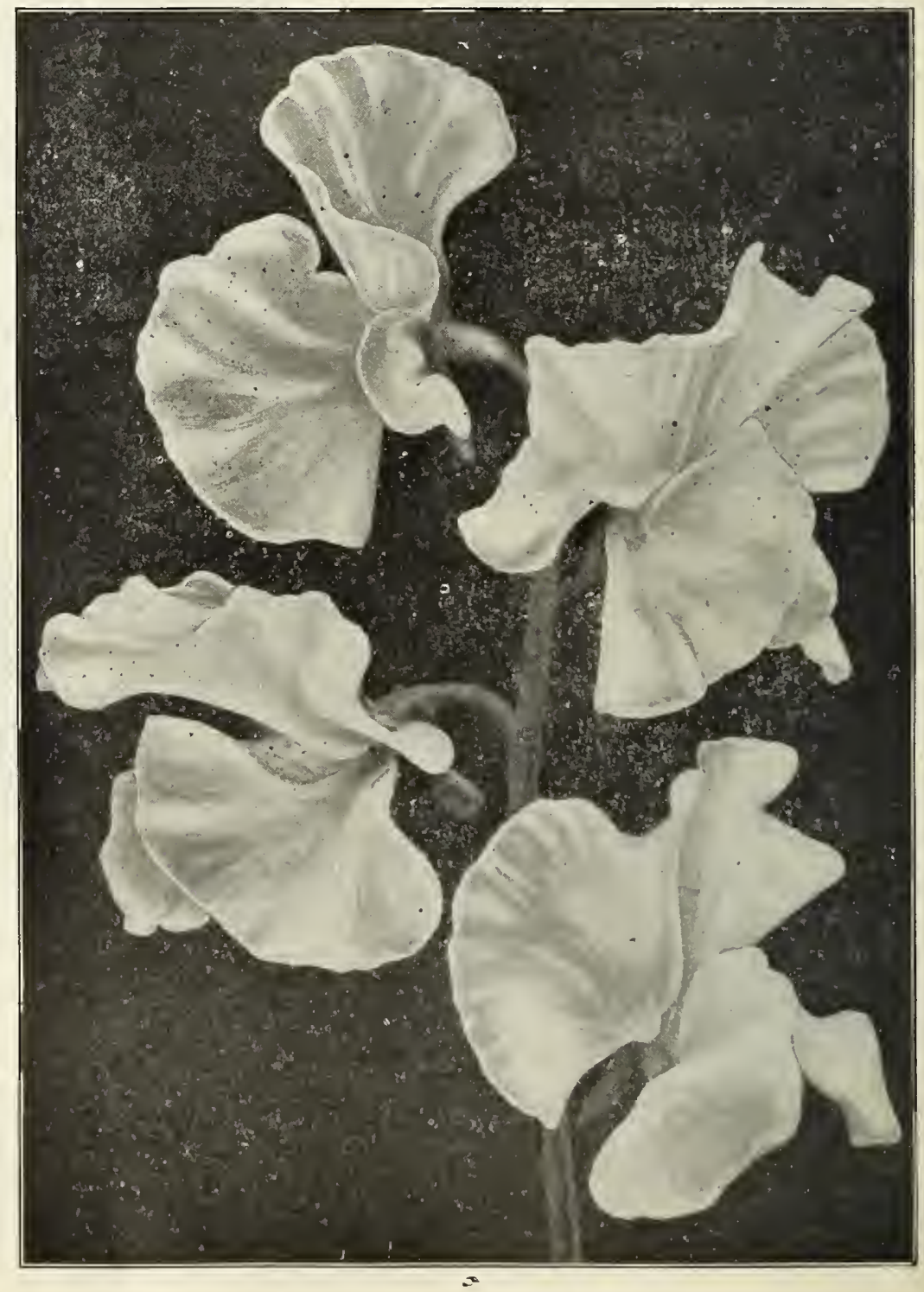


Dorothy Tennant.-Deep rosy mauve. Extra Early Blanche Ferry.-Pink with white wings Fiora Norton.-Bright, clear blue.

Fiorence Fraser.-An improved Blanche Ferry. Gorgeous.-Salmon-orange.

Gracie Greenwood.-Soft salmon-pink deeper edge Hon. Mrs. E. Kenyon.-The best yellow.

Janet Scott.-Bright pink and buff.

Jeanie Gordon. - Standard rose, shaded cream.

Katherine Tracy.-Soft brilliant pink.

King Edward VIi.- Intense bright crimson.

Lady Grisel Hamilton.-The best lavender.

Price of all Sweet Peas, uniess otherwise noted, packet 5c, ounce 10c, 4 ounces 20c, pound 60c

"Dallwig's Best Mixed" Sweet Peas. This mixture of Sweet Peas is undoubtediy the finest ever offered. It contains all the best named varieties of the large flowering type as well as the popular Unwin and Countess Spencer types, carefully selected and mixed by ourselves, with a liberal proportion of the novelties of the year.

Packet 5c, ounce 10c, t pound 25c, pound 75c

IF SWEET PEAS ARE WANTED BY MAIL, ADD 2 CENTS PER $\frac{1}{4}$ POUND, 8 CENTS PER POUND.

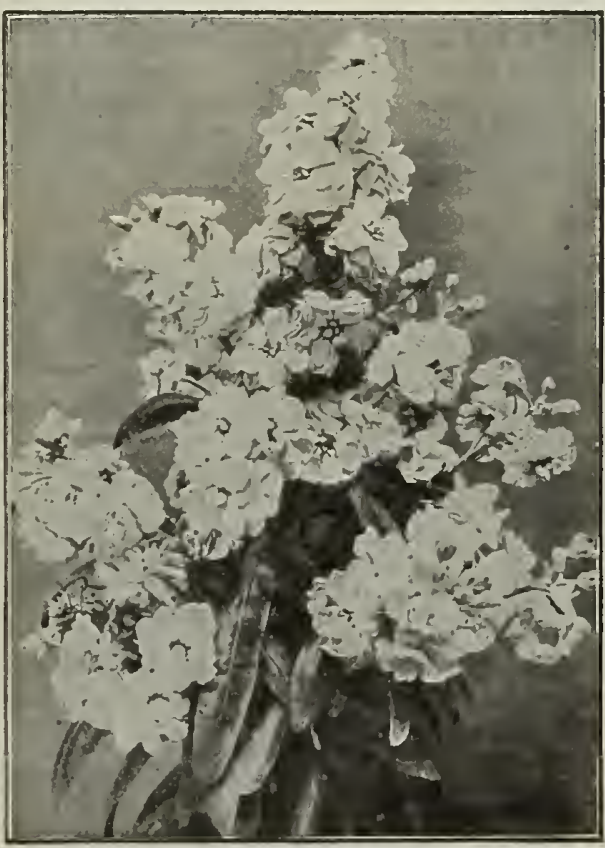

STOCK, BEAUTY OF NICE
STC S These are among the best and orites. In brilliancy of color and sweetness of perfume they are unsurpassed.

Large Flowering Waliflower Leaved.-Deep bloodred, blue, dark blue, crimson, white, yellow. Packet 5c Princess May.-(Wallflower Leaved.) Fine, l a rge, double flowers, pure yeliow. Forms a compact pyramid, bearing flowers one and one-half inches across. Highly recommended. Packet 10e Giant Perfection, or Cut and Come Again.-This variety is almost a perpetual bloomer. Flowers double and very large. White, dark blue, reddish brown, bright crimson-purple, crimson, mixed. Packet 5c Mammoth White Column.-Snow white; distinguished by a remarkably vigorous growth, and magnificent, gig a n tic double flowers, borne on long stems, making them valuable as cut flowers. Packet 10c Dwarf Pyra. midal. $-\mathrm{We}$ cán highly recommend this variety. White, pink, crimson, light blue, dark blue, mixed. Packet 5c

Dwarf Bouquet.--Low compact growth; much branched and a long bloomer. White, crimson, light blue, deep bloodred, brilliant rose, mixed.

Packet 5c

BEAUTY OF NICE. New Winter Stock.-Well - b r a n ched plants bearing a profusion of very large, sweet-scented flowers of flesh-pink color. Blooms in 14 weeks, so that it may be treated as a summer stock. Blooms all summer, fall and winter.

Packet $10 \mathrm{c}$

BEAUTY OF NiCE. Aimond Fiowered.-Color white flushed carmine-rose.

Packet $10 \mathrm{c}$.

NEW STOCK "PRINCE BISMARCK".-Of robust, pyramidal growth, attains a height of 30 inches, produces many long flower spikes covered with large, pure white double flowers. The plants begin to bluom when other Ten Week Stocks have stopped blooming, continuing until late in the Fall.

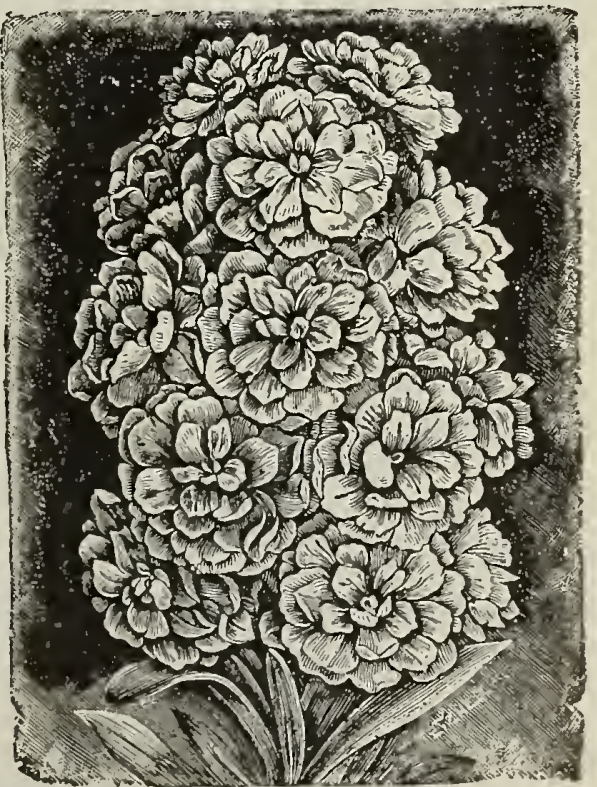

STOCK, PRINCESS MAX Packet 10c. 


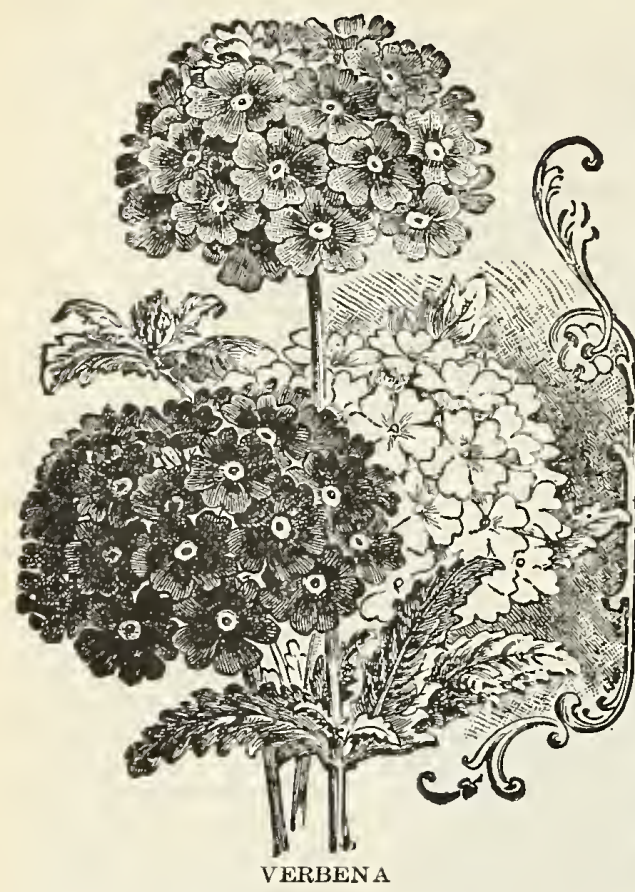

VERBENA. The Verbena is one of the most Loffective bedding plants in culed in the splendor of its dazzling brilliancy of flowers; of very neat habit; a constant bloomer. Auricula flowered (white-eyed), pure white, scarlet, dark blue, blue with white eye, striped, Defiance (rich scarlet), mixed colors.

Dwarf Defiance.-Bright scarlet.

Packet 5c Seed saved from perfect flowers only. Packet $10 \mathrm{c}$

VIOLA. Sweet Violet.-There is probably no plant that can equal the Sweet Violet for delicate and delicious fragrance. It always has been and always will be a prime favorite. Unsurpassed for planting in borders where the situation is rather moist and shady. They bloom freely and give unending delight with their beauty and fragrance.

Semperflorens Blue.-Everblooming, sweet-scented.

Packet 5c

Wallflower. The conspicuous spikes of the a charming effect, while the compact and more bushy growth and profuse blooming of the single ones render them exceedingly attractive. Half hardy perennials.

Finest Double.-Yellow, brown, and mixed. Packet 10c Single Mixed.-

Packet 5c

ZEA JAPONICA. A variety of corn with ornamental foliage; leaves green and white. Half hardy annual; six feet high.

\section{ZINNIA}

Few flowers are so easily grown from seed sown in the open ground, or bloom so abundantly and continuously as this hardy annual. Marvelous improvements have been wrought in the newer strains. During the month of August Zinnias are almost incomparably bright. We recommend a free use of them for groups, beds, borders, garden lines and summer hedges. Average height, $1 \frac{1}{2}$ to 2 feet.

Large Flowering Dwarf.-White, crimson, yellow, scarlet, pink, orange-red, carmine, purple, mixed. Packet 5c

\section{Mixed Flower Seed}

This contains many desirable varieties, and is well adapted for use by woodland walks, and naturalizing purposes, as well as general garden work. Packet 5c

Dahlias. Within the last few years there has been a wonderful revival of interest in the view of selecting the best of the newer varieties as respects free and continuous blooming quaiities, purity of color and perfection of form. See pages 75 to 79 .

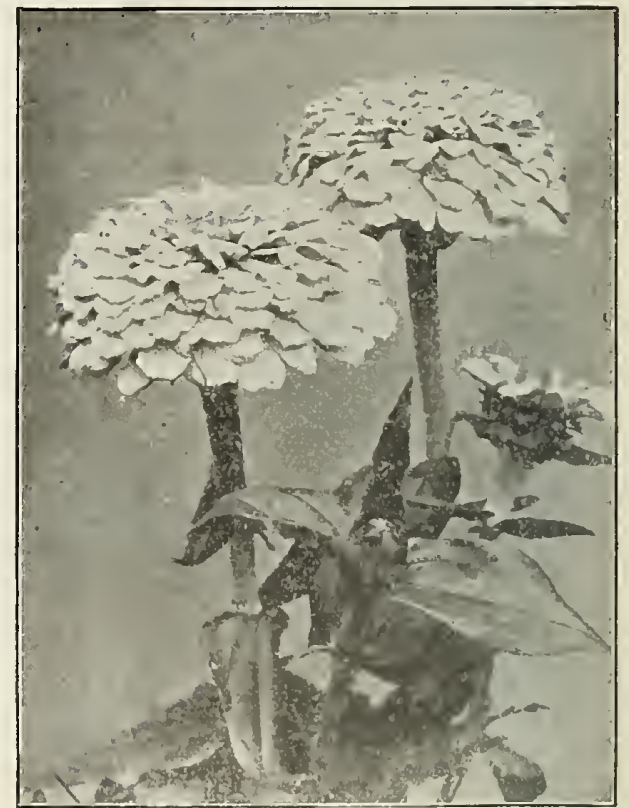

LARGE FLOWERING DW ARF ZINNIA

\begin{tabular}{|c|c|}
\hline $\begin{array}{c}\text { GARDENING } \\
\text { BY } \\
\text { CHILDREN }\end{array}$ & $\begin{array}{l}\text { No occupation is as healthy, innocent or instructive to a child as a practical } \\
\text { study of nature. No matter how small the space of ground the pleasure to a child } \\
\text { of cultivating a little garden will always develop ambition, and the pleasure of ob- } \\
\text { serving the growth from the day the seed sprouts until the piants attain perfection } \\
\text { is in itself a lesson which both young and old can appreciate. 'The good, whole- } \\
\text { some benefit derived by the children must necessarily cultivate the mind, while at } \\
\text { the same time amuse. } \\
\text { Heads of Institutions and School Managers would do well to cultivate in the } \\
\text { minds of the children under their charge a love of nature and the beautiful. } \\
\text { Annual flowers such as Balsam, Mignonette, Four O'Clocks, China Pinks anc } \\
\text { Phlox are all easily raised and afford a showy display at small cost and little labor. } \\
\text { In Vegetable Seeds our selection in unexcelled. }\end{array}$ \\
\hline
\end{tabular}




\section{SEEDS OF HARDY PERENNIAL PLANTS.}

The popularity of this class of plants, familiarly known as Old-Fashioned Hardy Garden Flow. ers, is not at all surprising when we consider the many varied and pleasant changes which take place throughout the entire growing season in a well-arranged hardy border.
Seeds of Biennials and Hardy Perennials may be sown in July and August in the open, and in September in boxes and placed in cold frames. They will make strong plants by spring and flower early.

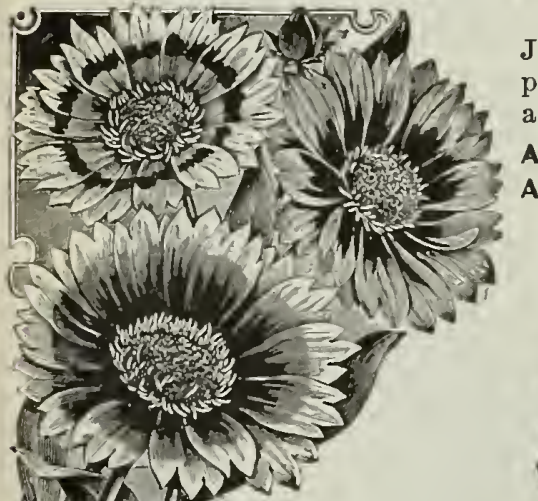

Alyssum Saxatile Compactum.-Golden yellow.

Aquilegia.-Rocky Mountain Columbine. See ill. page $\mathbf{4 6}$

is Bellis.-Double Daisy. White and pink.

Campanula.-Canterbury Bell. Single mixed, single blue, double mixed, double blue.

Cup and Saucer, mixed.

Carnation.-Double.

Coreopsis Lanceolata.-Bright golden yellow.

Daisy, Shasta.-Large, pure white flowers. See illustration page 49 .

Packet 10c

Delphinium. Hardy Larkspur. The long spikes of flowers a re produced continuously until late in fall.

D. Formosum.-Deep blue with white eye.

D. Sinensis.-

D. Sinensis fl. pl.-Double.

Dianthus Barbatus. - Sweet William. See illustration page 68 .

Dianthus Plumarius.-Pheasant's Eye Pink.

Digitalis.-Foxglove. A wealth of flowers in June and July.

Gaillardia Grandiflora.-Showy and effective. Continue one mass of bloom all summer. Center is dark reddishbrown, petals marked with rings of brilliant scarlet-crimson, orange, and vermilion. Packet 10c

Gypsophila Paniculata.-A ls o known as Baby's Breath. Minute white flowers of beautiful gauze-like appearance August-September.

groups on the lawn, or

for interspersing among shrubbery they are invaluable.

Chater's Prize Hollyhocks.-Double white, yellow, pink, scarlet, crimson, salmon, and mixed. Pkt. 15c

Good Mixed.

Lobelia Cardinalis.-Rich fiery cardinal flowers.

Lychnis Chalcedonica.-Large heads of vermilionscarlet flowers.

Hardy Phlox. The hardy Phloxes are without doubt the most important of all hardy perennials, and can now be found in almost every garden. They flower from early summer until late in the fall, and contain a range of brilliant colors not found in any other hardy plant. Mixed colors. (See page 84). POPPY. Oriental.-Mammoth scarlet, with black cen. ter. See illustration page 84 .

Oriental Hybrids.-Mixed colors.

Iceland Poppies.-Mixed colors.

Scabiosa Caucasica.-One of the handsomest perennials for cutting purposes. The flowers are of a peculiarly soft and charming shade of lilac-blue. June to September See page 84.

Stokesia Cyanea.-(Cornflower Aster.) Handsome, lavender-blue, centaurea-like blossoms.

Per Packet 5c, unless otherwise noted.

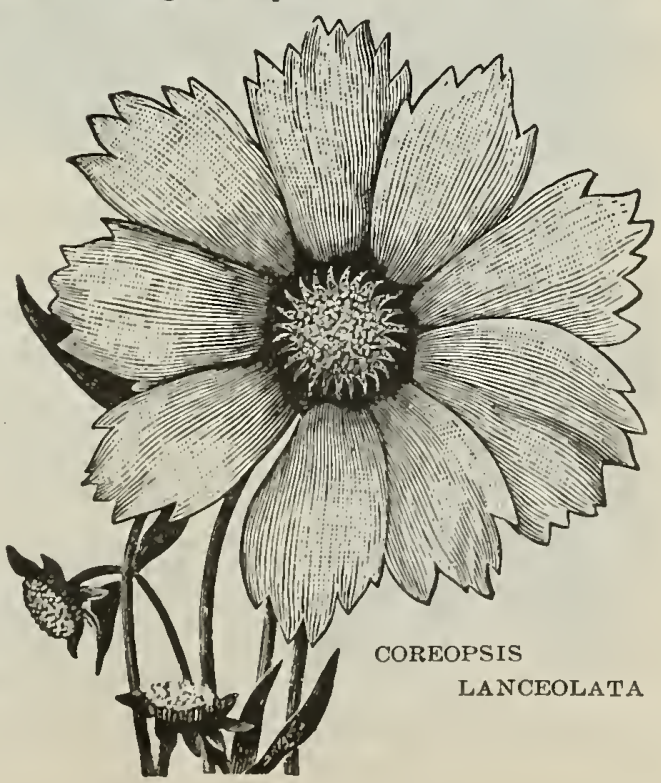


BALLOON VINE. Remarkable for its inflated membranous capsules; sometimes called "LoveCanary Bird Flower. - One of the most charming climbers, bearing an abundance of bright

COBAFA - A rapid growing climber, sometimes attains the height of COBAEA.thirty feet in a season. Flowers first green changing to a deep blue-violet. To prevent it from rotting place the seeds edgeway and cover slightly with light soil.

Per packet $5 \mathrm{c}$

CHARANTIA. (Balsam Pear.) - A rapid growing climber with very when ripe, disclosing the seeds encased in a carmine covering. The fruit, preserved in alcohol, makes a useful linement.

Per packet $5 \mathrm{c}$

Dolichos or Hyacinth Bean. Of quick growth, the foliage dense ant and pretty, and the seed pods shining, large and of a purple-violet color. Red, white and purple.

Per packet $5 \mathrm{c}$

Gourds Ornamental. All of this climbing genus are of rapid growth

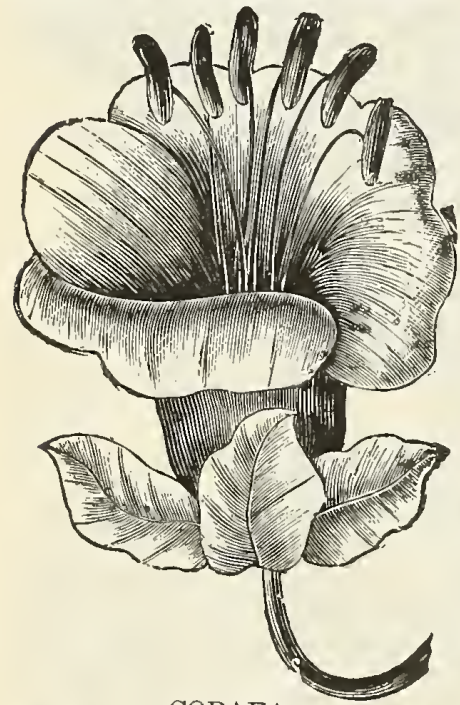
and produce fruit of peculiar and varied form. Gooseberry.-Small, bright green.

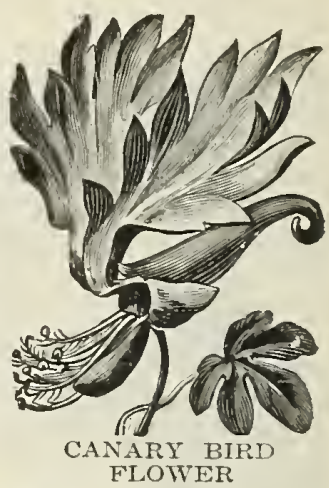
Snake.- Pear Shaped.-Green, striped with cream,

Egg, Bottle Shaped, Apple, Orange, Small Onlon Shaped, Smail Pear Shaped Marbled, Smallest Green Strlped Apple, Flattened Bottle. Mixed.

Per packet $5 \mathrm{c}$

$1 P O M O A$ Elegant twining plants, with handsome, - showy flowers and beautiful foliage. Excellent for trellises, arbors, fences, etc.

Cocclnea. (Star Ipomoea.) -Scarlet free flowering.

Packet 5c

Quamoclit. Cypress Vine.-A favorite, well-known, climbing vine, with graceful, airy foliage and handsome flowers. Scarlet.

Per packet $5 \mathrm{c}$

Ipomea Moon Flower or Evening Glory.)Ipomoea Noctiflora. Magnificent climber, producing handsome dense foliage and a large number of clear white, very fragrant flowers. Start in the house and plant out after danger of frost is past.

Per packet $5 \mathrm{c}$

NEW JAPANESE HOP. It resembles in habit our common NEW JAPANESE HOP. hop, but the foliage is more deeply cut, and very dense. An extremely rapid grower. Per packet 5c Variegated Foliage.-Very beautiful variety. Easy to grow.

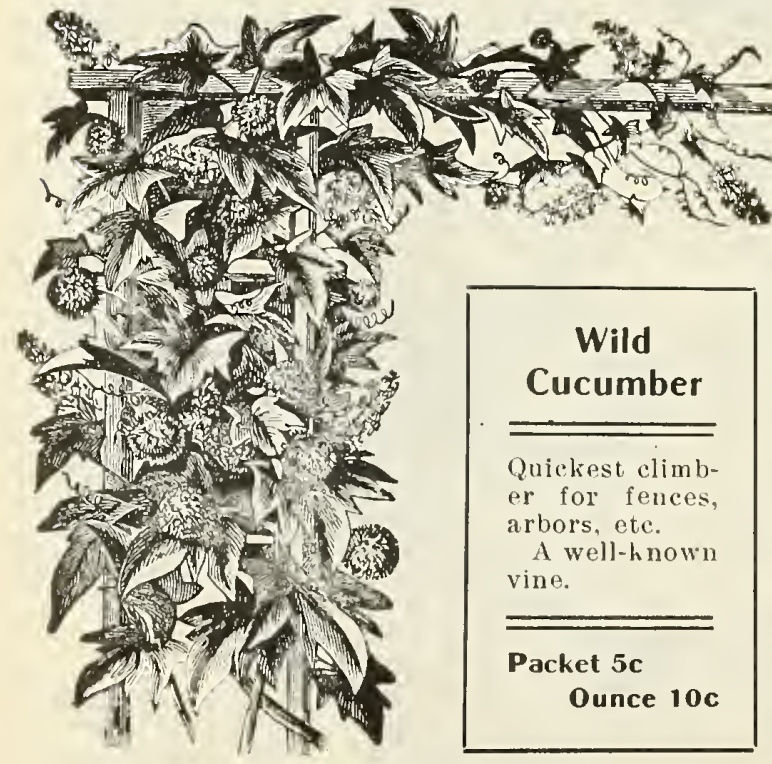

WILD CUCUMBER

\section{For Hardy Climbing Vines}

\section{See Pages}

\section{0 to 93}




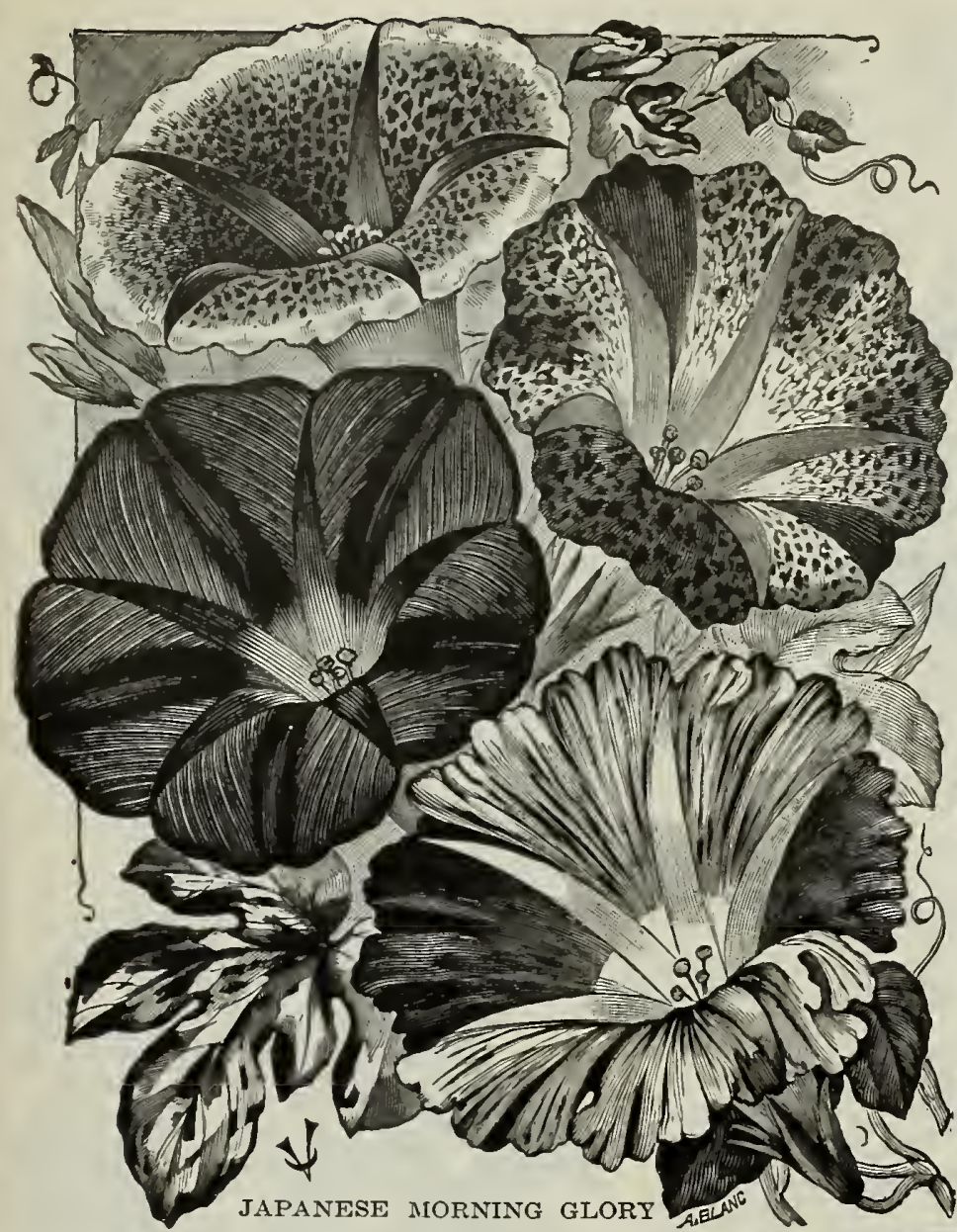

LOPHOSPERMUM SCANDENS. Quick growing, graceful climber, excellent for use in hanging baskets, or in a shady gituation. Flowers rosy purple.

Per packet $5 \mathrm{c}$

MINA LOBATA. $-\mathrm{O}$ the of beautiful climbing vines. The flowers appear an forklike racemes, rising almost erect out of the dense and luxuriant foliage; are as buds at first bright red, but change through orange yellow to yellowish-white when in full bloom. It is a very rapid 'growing climber, forming pyramids of over eighteen feet in height, most ornamental in appearance, the leaves being three lobed. Per packet $10 \mathrm{c}$

\section{Imperial Japanese} Morning Glory.- $\mathrm{Tl} \mathrm{h}$ e are of exquisite beauty in form and coloring and of enormous size. The colors vary from pure white to rose, crimson and carmine, through blues and purples to almost black, some being mottled, striped, penciled and bordered in infinite variety and diversity. The foliage also is often prettily variegated.

Per packet $5 c$

Fancy Frilled Japanese Morning Glorles.-This mixture contains a finer and larger collection of colors with larger flowers, more frilled than the ordinary mixture.

MORNING GLORY. MIxed.-

Per pound $50 \mathrm{c}$, ounce $10 \mathrm{c}$, packet $5 \mathrm{c}$

Momordlca Balsamina. (Baisam Beautiful climbing plant with handsome apple-shaped fruit. Por packet 5c

Maurandia. - A climber having tube Maurandla. shaped flowers which last until late in the fall. Ten feet.

Maurandia Barklayana.-Blue. Mixed.Per packet $5 c$

PASSION FLOWER. - $\mathrm{H}$ and s o m $\theta$

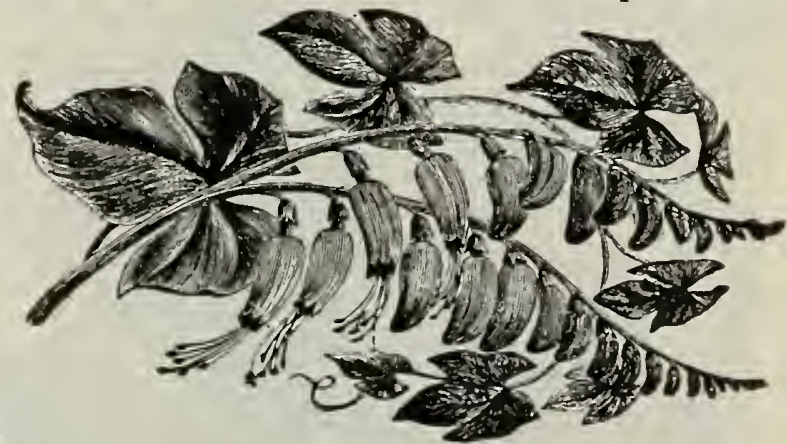

MINA LOBATA.

for greenhouse decorations and sunny positions in the open ground in summer.

Passiflora Coerulea.-Slightly fragrant. Light blue.

Per packet $5 c$

SMILAX.This is the most useful greenhouse climber known; foliage small, glossy-green, flowers SMILAX. small, white, very fragrant. Eight to ten feet.

SCARLET RUNNER.-Height six feet; cultivated for the beauty of its ilowers and also as a useful vegetable. Per packet $\sigma_{c}$

VINES. There is no other class of plants that possesses quite so much grace and poetry as pretty trailing or climbing vines. It has been truly said that they are Nature's drapery. They add beauty and attractiveness to the plainest of dwellings, and should be lavishly trained over windows, porches and porticos, or wherever they will add finish and effect. The work should not be overdone, however, and should not be confined to the house alone. Outhouses, as barns, henneries, etc., may be attractively covered and much that is inartistic concealed. 


\section{SUMMER FLOWERING BULBS.}

AMARYLLIS. Formosissima.-Each of the five narrow petals is from three to four inches long, and of a very intense, rich scarlet. Each $10 \mathrm{c}$, dozen $\$ 1.00$ A. Johnsoni.-Immense trumpet-shaped flowers of rich, deep, velvety crimson, each petal having a broad white stripe, con-

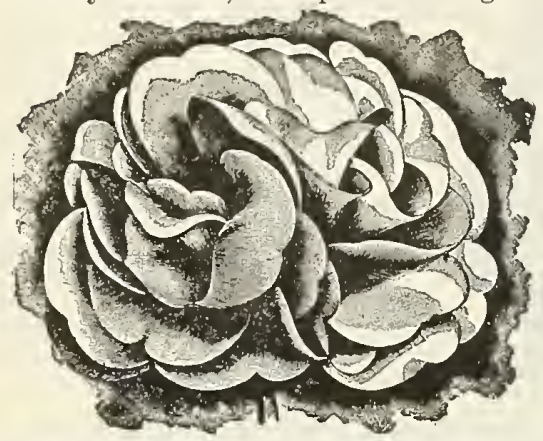
trasting bea utifully with the deep red color. Each 25c \& 35c

Tuberous Rooted BEGONIAS

These showy flowers have become very popular and deservedly so. From the time the first flowers expand until frost puts a stop to further blooming, they are literally covered with DOUBLE TUBEROUS ROOTED BEGONIA. flowers of the richest

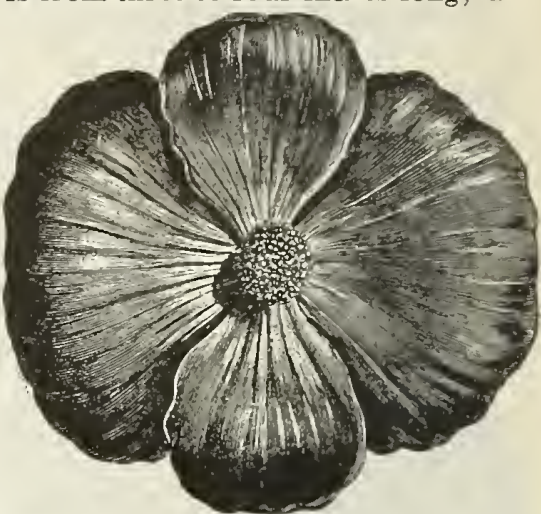

SINGLE TUBEROUS ROOTED BEGONIA. colors, more brilliant than the most dazzling geraniums. They want protection from the hot sun. Single.-White, scarlet, pink, yellow. Ea. 7c, doz. 70c Double.-Same colors. Ea. 10c, doz. $\$ 1.00$

\section{CALADIUM ESCULENTUM ELEPHANTS'}

Enormous leaves. One of the finest sub-tropical plants which can be grown in the open air in the North. It is of easy culture, the chief requisites being a rich soil, and an unlimited supply of water. Very effective for the flower border and for planting out upon the lawn, especially with Cannas or Castor Oil plants.

Each $8 \mathrm{c}, 10 \mathrm{c}$, and $15 \mathrm{c}$; dozen $80 \mathrm{c}, \$ 1.00$, and $\$ 1.50$ Postage $4 c, 6 c$, and $8 c$ per bulb extra.

CANAS. These very handsome, tropicalaffects on the lawn; there large glossy green and red leaves and showy spikes of flowers produce an effect seldom equaled.

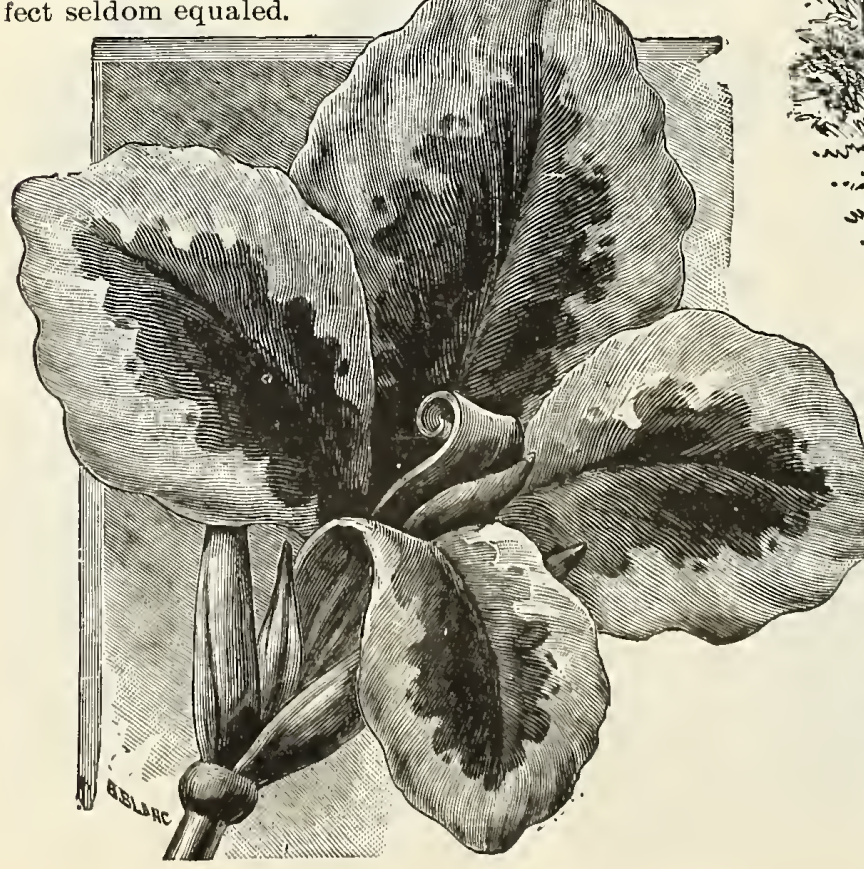

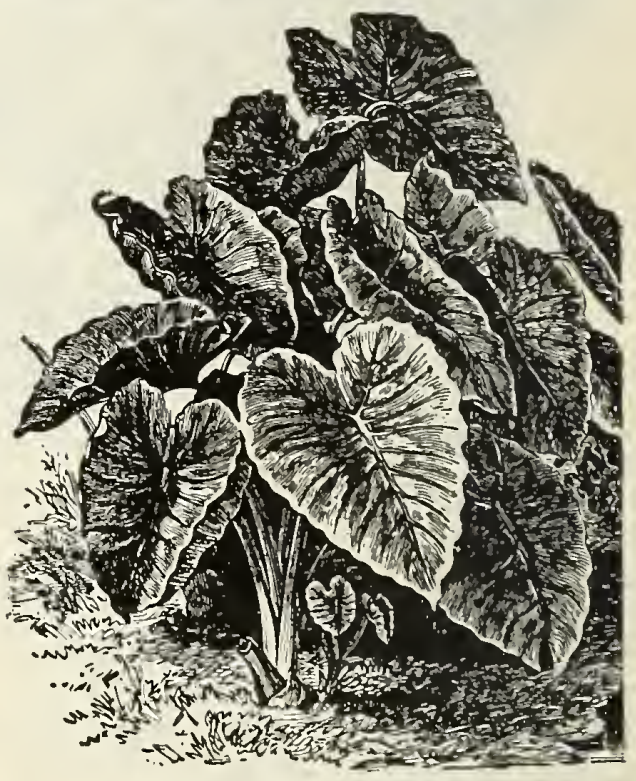

C ALADIUM ESCULENTUM.

\section{Large Flowering Cannas}

Alphonse Bouvier. -5 feet. Crimson. Austria.-6 feet. Canary yellow.

Burbank. -5 feet. Orchid-flowered, rich yellow, inner petals spotted crimson. Chas. Henderson. -4 feet. Crimson.

Egandale.-4 feet. Bronze foliage; color currant red.

Florence Vaughan. -4 feet. Golden yellow dotted with carmine.

Mad. Crozy, -4 feet. Vermilion, bordered gold.

Queen Charlotte. -4 feet. Rich crimson scarlet, wide gold border.

ABOVE VARIETIES: Each 10c, per dozen $\$ 1.00$ 


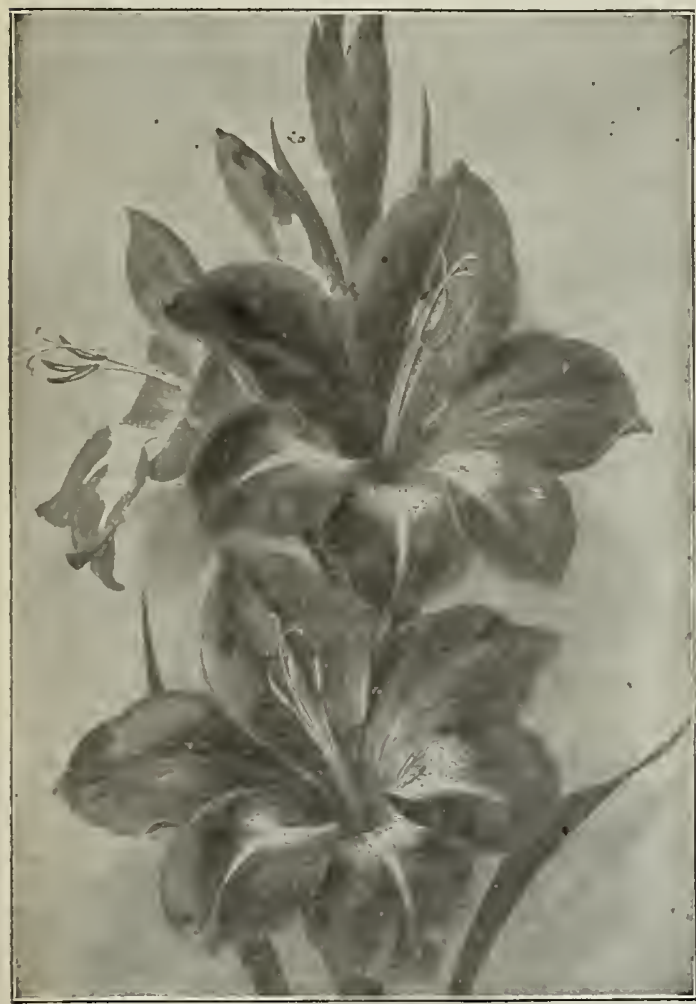

PRINCEPS FLOWER SPIKE
CANNAS KING HUMBERT.-King of Cannas. Continued Massive and handsome bronze foliage. Produces freely spikes with enormous heads of the largest flowers. Color is a brilliant rich orange scarlet. $4 \frac{1}{2}$ feet.

Each 15c, per dozen $\$ 1.50$

CINNAMON VINE.-This charming climber has beautiful glossy heart-shaped leaves, and delicate small white flowers of most delightful odor.

Each 5c, dozen 50c

\section{GLADIOLI FLOWERING}

The Gladiolus constitutes one of the finest features of the flower garden during the summer and autumn months. Every desirable color is represented from the most intense scarlet to the purest white.

America.-The finest pink gladiolus produced to date. Most beautiful soft flesh pink, very light, slightly tinged with lavender, which gives it the delicate coloring of a lælia. Strong erect spike of the largest flowers, set to show to the best advantage. $\quad$ Each 10c, dozen 75c, $100 \$ 5.00$ Augusta.-Pure white, blue anthers.

Each 4c, dozen 40c, $100 \$ 2.50$

May.-Pure white flaked rosy crimson. Each 4c, dozen 35e, $100 \$ 2.00$

Mrs. Francis King.-Always very vigorous and healthy, free from disease in bulb or leaf; has a long effective flower spike, with individual flowers 4 inches across, and with 5 to 6 flowers open on a spike at one time; color is of a Flamingo pink, blazed with some red, and most effective both in daylight and under artificial light.

Each 5c, dozen 50c, $100 \$ 3.00$

Princeps. -One of the finest and most perfect varieties. It grows from $3 \frac{1}{3}$ to 4 feet high, with very broad and handsome foliage which forms a grand setting for the brilliant amaryllis-like blooms. The color is a rich crimson, with intense shadings in the throat and broad white blotches on the lower petals. The flowers measure 5 inches in diameter.

Each $15 \mathrm{c}$, dozen $\$ 1.50$

\section{GLADIOLUS MIXTURES}

Light and White.-

Pink Shades.-

Red and Scarlet.-

Childsii Mixed.

Good Mixed. -

Doz. $30 \mathrm{c}, 100$

" $30 \mathrm{c}$,
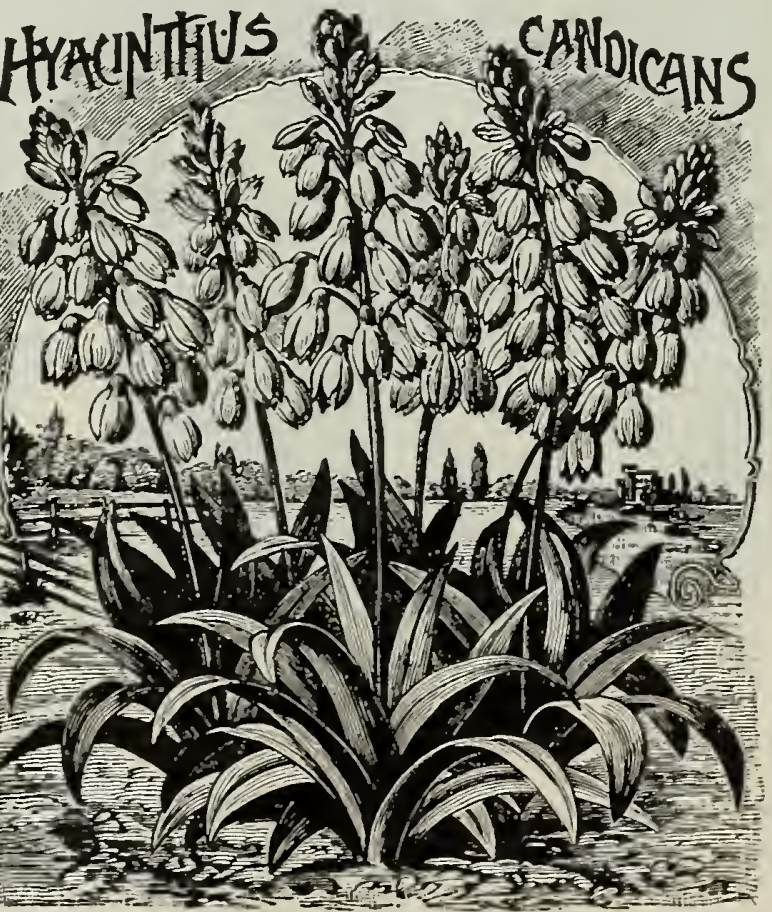


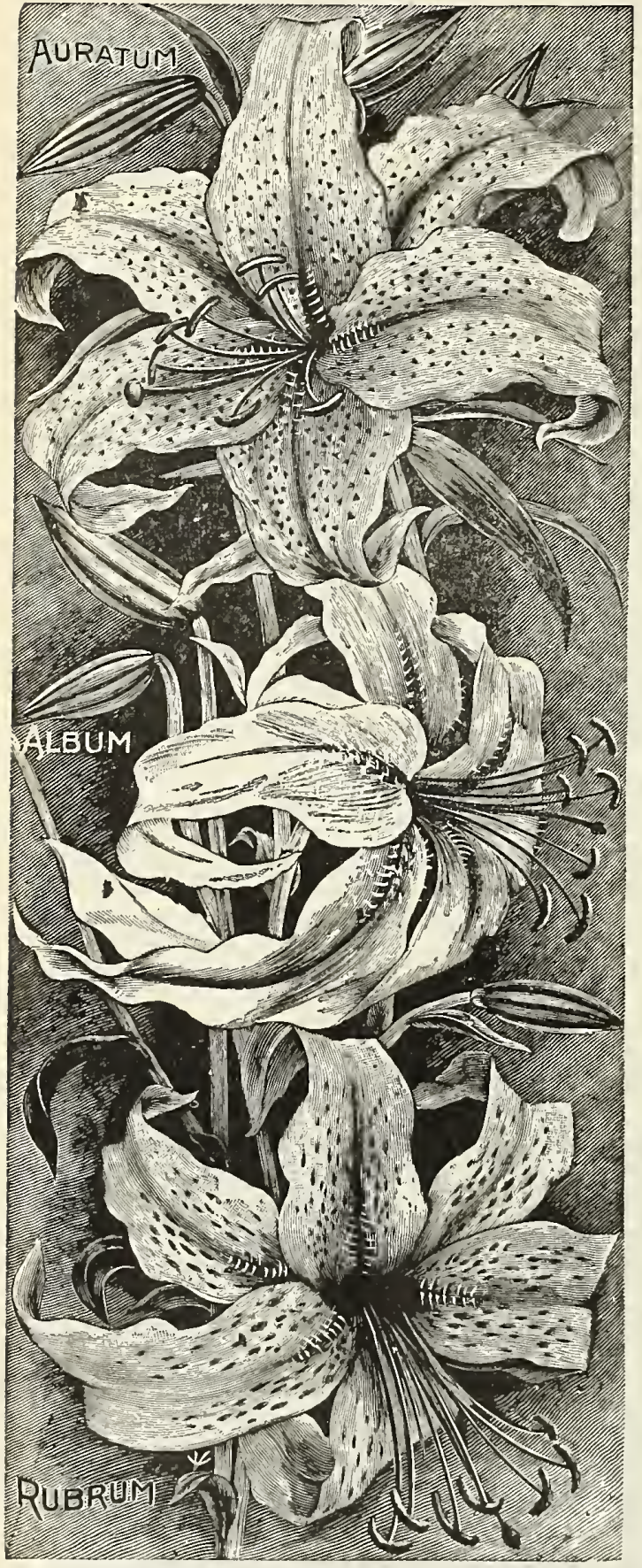

and red flowers.
GLOXINIAS. New Giant Flowering Hybrids. Beautiful house plants af $d$,rarf habit and easy culture. Flowers are trumpet-shaped with beautiful markings.

Defiance.-Rich crimson-scarlet.

Emperor Frederick.-Red with white border. Emperor William.--Violet-blue, white throat, beautifully streaked and spotted.

Mont Blanc.-Pure white. Ea. 10c, doz. $\$ 1.00$

\section{HARDY LILIES}

Too much cannot be said in praise of the Lily, with eminent propriety styled the "Queen of Flowers". No flower is more expressive of queenly beauty and faultless purity than the Lily. They thrive best in a dry, well drained. rich soil. All Lilies offered below are hardy enough to stand the winter outdoors. It is well, however, to protect them with litter or straw.

ALL OUR LILY BULBS ARE FIRST SIZE.

\section{THE THREE QUEENS}

Auratum, Album and Rubrum. No flower garden is complete without these three grand lilies Their ease of culture, hardiness and freedom of bloom commend them to every flower lover.

AURATUM.- The Gold Banded Lily of Japan.

This peerless variety is without question the grandest of all the Lily family. The flowers are pure white, thickly studded with crimson spots, while through the center of each petal runs a clear golden band. Flowers measure from 7 to 10 inches across, produced abundantly; deliciously fragrant. Each $15 \mathrm{c}$, dozen $\$ 1.50$

SPECIOSUM ALBUM.-Pure white, with beauti ful recurved petals, very fragrant. They are graceful, free-blooming, perfectly hardy, and will grow and flower without special treatment. Each $15 \mathrm{c}$, dozen $\$ 1.50$

SPECIOSUM RUBRUM.-Crimson Banded. The magnificent flowers are white, with a deep rosy or crimson band on each petal, with deeper colored spots between. They are five to six inches in diameter, very fragrant, and have all the hardiness of the Speciosum class.

Each $15 \mathrm{c}$, dozen $\$ 1.50$

SPECIOSUM MELPOMENE.-A most beautiful variety. Flowers frosted white, spotted, clouded and bearded with pinkish crimson. Petals deeply recurved and widely bordered.

Each $15 \mathrm{c}$, dozen $\$ 1.50$

IF ABOVE LILIRS ARE WANTED BY MAIL ADD 3 CENTS A BULE. Canadense, Meadow Lily.-This pretty Lily is one of our hardy native sorts, and bears a graceful stem of drooping, bell-shaped, yellow Each $10 \mathrm{c}$, dozen $\$ 1.00$

Tenuifolium, Siberian Lily.-One of the very hardiest Lilies; flower's vivid scarlet, with petals reflexed; very showy and free flowering, blooming early in the spring.

Each 15c. dozen $\$ 1.50$

Tigrinum, Tiger Lily.-Very hardy native lily; orange-red, spotted with purplish-black.

Each 8c, dozen $75 \mathrm{c}$

LILY OF THE VALLEY. -No garden is complete without a few clumps of these fragrant flowGlossy foliage and spikes of graceful white bells of delicious fragrance. 1. Large clumps, each $25 \mathrm{c}$, dozen $\$ 2.50$, by express or freight. 
MADEIRA VINE.-A rapid growing graceful vine, with smooth, waxy, dark green leaves and dainty racemes of tiny, fragrant, white flowers. Ea. 5c, doz. 50c TUBEROSE. Double Dwarf Pearl.--Pure white, perfectly double, delightfully fragrant; invaluable for bouquets.

Each 5c, dozen 40c

Japanese Fern Ball.-The Ball is composed of Japanese Island Fern Roots and Sphagnum Moss, and so constructed as to send out leaves of beautiful emerald green from every point. They grow rapidly, and make a handsome ornament for the home, conservatory or greenhouse. Place ball in water until thoroughly wet and then suspend in any desired position; repeat every two days until growth is started, after which sprinkle occasionally as required. Dormant, each 50c

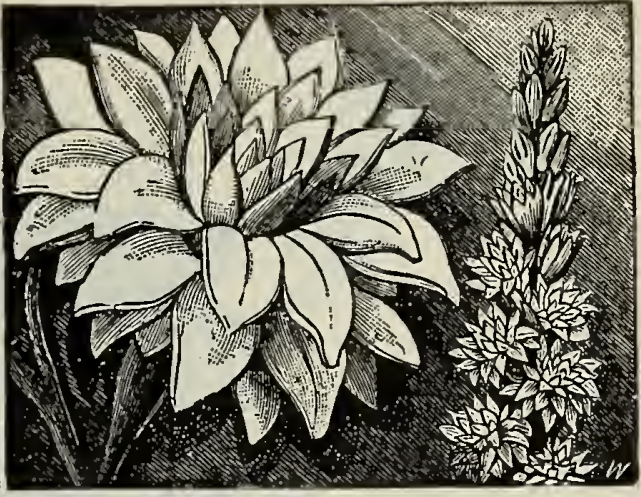

TUBEROSE, DOCBLE DWARF PEARL.

Dutch or Holland Bulbs for Fall Planting. - Our importations of Dutch Bulbs principal growers in Holland for a number of years past wave been made from some of the heavy bulbs, producing beautiful blooms, all true to name and color.

READY SEPTEMBER 1 st.

\section{SEND FOR FALL CATALOG.}

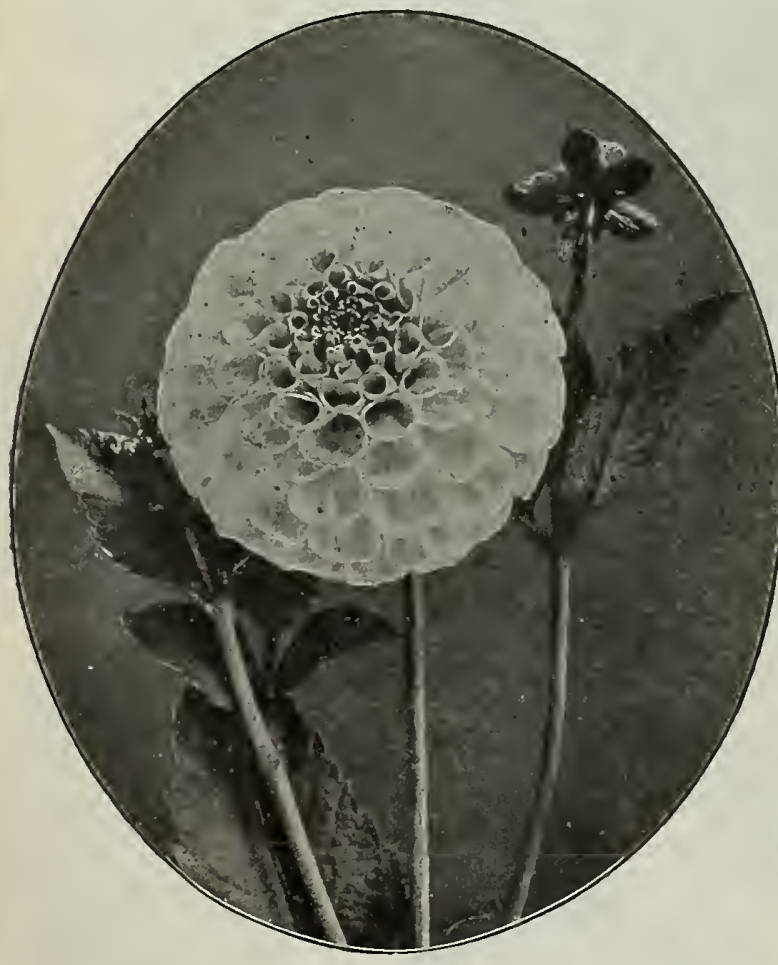

TYPE OF SHOW DAHLIA

\section{DAHLIAS}

After some years of comparative neglect, the Dahlia is steadily regaining its old-time popularity. This is not strange when we consider how many new varieties have been introduced, and how large a list of desirable kinds we now offer. Wonderful advances have been made in variety and size of flowers, keeping qualities, and strength of stem. Their brilliant colorings and wonderful variety make them effective as garden plants or for cut. $\xi$

The varieties which offered below have been selected for their free and continuous flowering qualities, purity of color and perfection of form. Our collection is constantly being enlarged by the addition of meritorious novelties.

WE SEND OUT ONLY STRONG ROOTS.

\section{CULTURE OF DAHLIAS}

We give here a few suggestions in regard to the culture of Dablias. They delight in and require an open, sunny situation and a sandy soil. The tubers should be planted 4 inches deep from the top of the crown and 3 feet a part. The best time for planting in this section is from May 15 to June 15. After the young plants have grown about 6 inches, the center bud should be pinched to make the plant branch freely. When the plant has grown a foot or so, an abundant quantity of cow manure should be heaped around the plant, and this should be constantly watered. Remove all imperfect buds as soon as they appear.

A. D. Llvonl.-Beautiful soft pink, with quilled petals, full to the center; early and profuse bloomer.

Bon Ton.-Deep garnet.

John Walker.-Fine pure white.

Mary D. Hallock. - A fine yellow quilled variety.

Ruby Queen.-Ruby red, richly shaded; fine, large flowers on long stems; profuse bloomer. Above varieties, each $15 \mathrm{c}$, dozen $\$ 1.50$

Double Dahlias to Color. Red, Pink, Yellow, White, Purple.

Strong field roots, each 10c, dozen $\$ 1.00 \quad$ Extra heavy clumps, each 15 c, dozen $\$ 1.50$ Send orders early, to assure complete selection. 


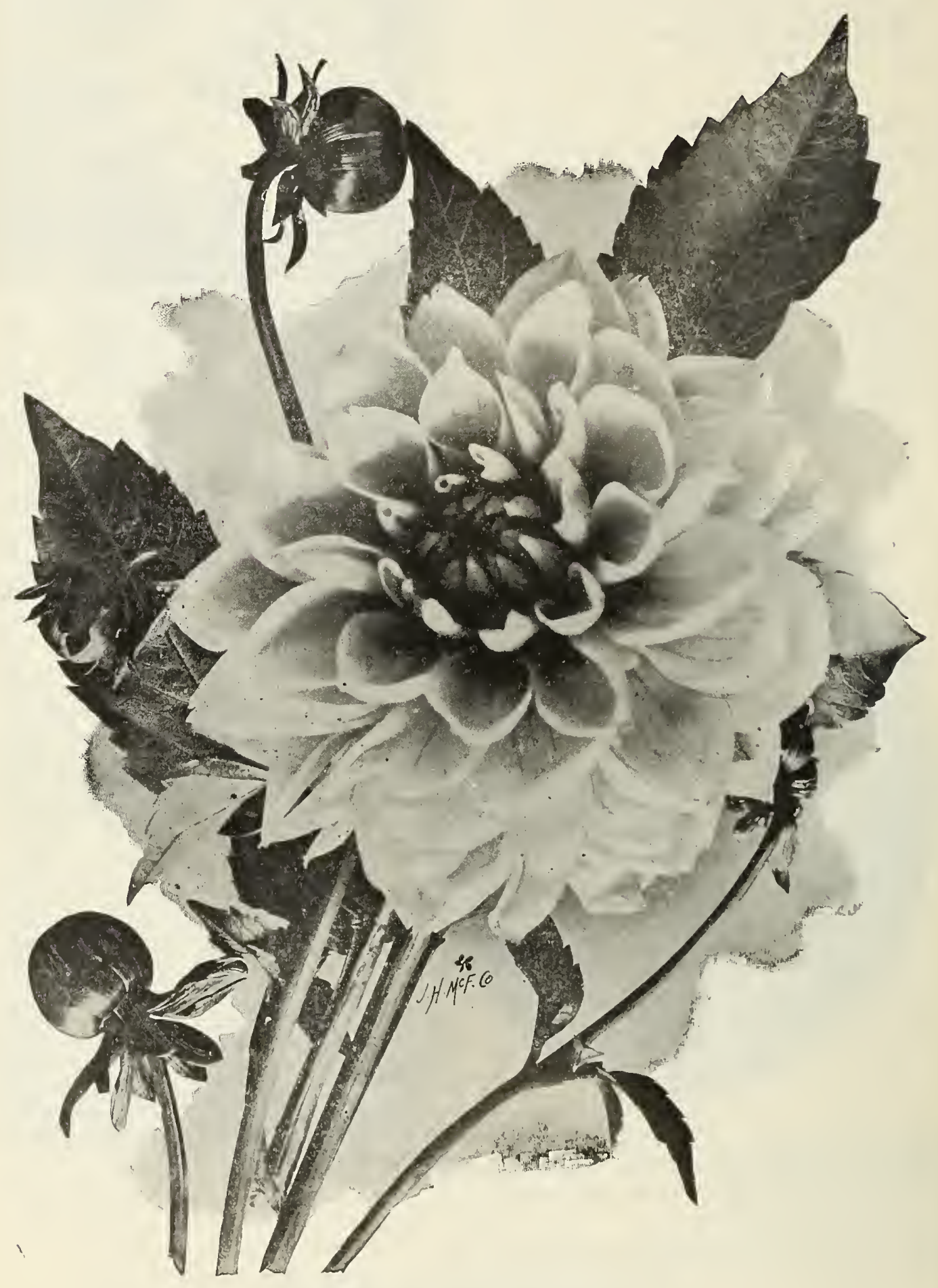

DECORATIVE DALIA, NYMPHAEA 

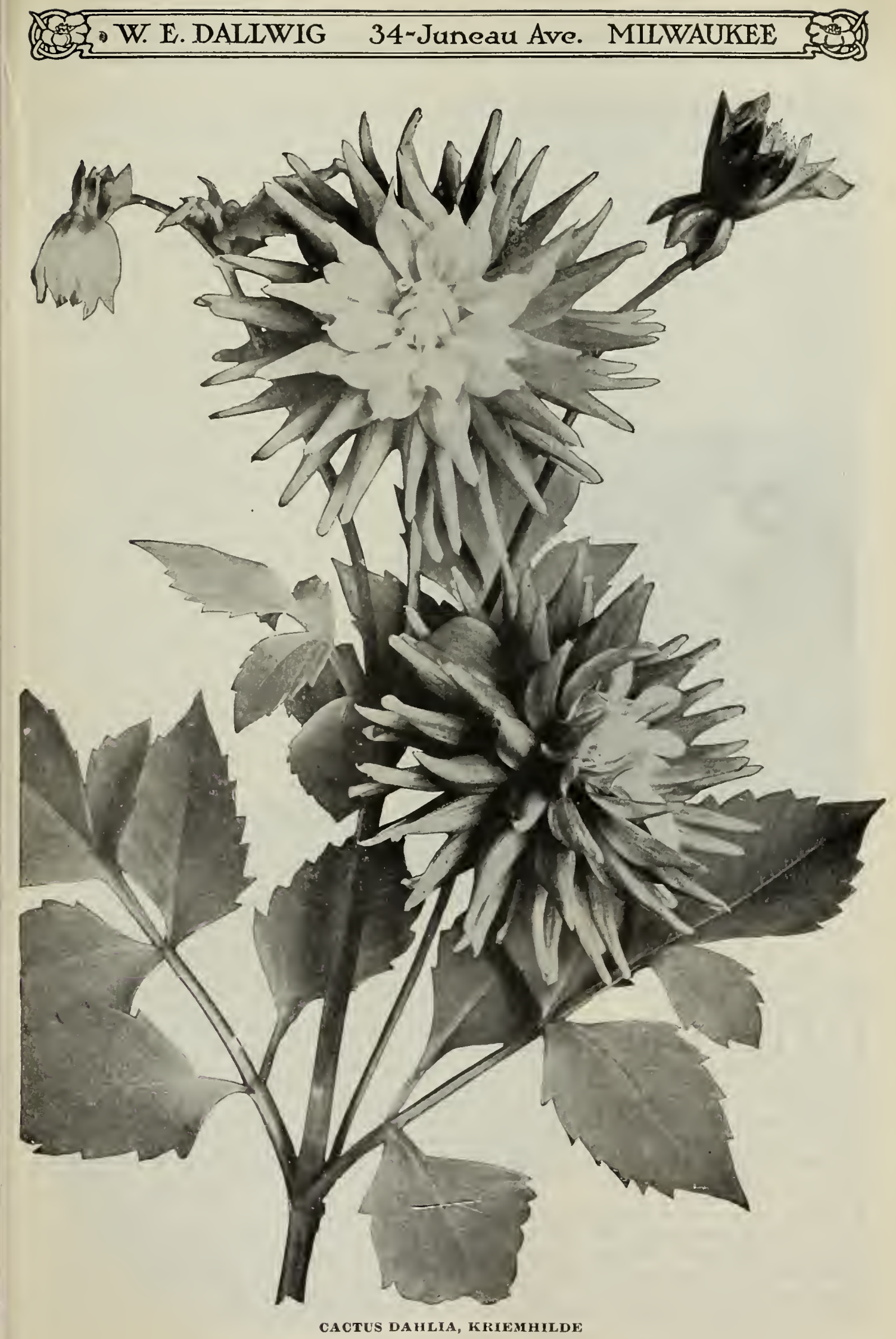


\section{DECORATIVE DAHLIAS, Thase are the latrege novering Dallisas with}

Cloose, open outline. They differ from the true hey are especially valuable for decorative work, as they are strong, vigorous growers and can be cut on long stems.

Catherine Duer.-Flowers of immense size, measuring seven inches in diameter; opens out flat, and shows no center. Color the most beautiful glowing red.

Clifford W. Bruton.-The best yellow; very large, of perfect form and of fine canary-yellow color. A tall, vigorous grower and extremely free bloomer.

DELICE.-New. The finest pink-colored Decorative Dahlia, excellent in form, perfect in type, superb yet delicate in coloring it must appeal at once to every lover of flowers. Color bright pink suffused with a lavender-pink.

Each $50 \mathrm{c}$

FIRE RAIN.- In this variety we have not only the rich cardinal-red color which made Lyndhurst so desirable, but a plant that produces masses of bloom early and continues throughout the season.

JACK ROSE.-The color is that of the universal favorite the "Jack" Rose (General Jacqueminot), from which it derives its name. That rich velvety crimson that appeals so strongly to everyone. In form it is that of an open rose, but always well filled in the center. Size of bloom from 5 to 6 inches; height of stem for each individual bloom 2 feet and over. The ideal Dahlia for cut.

Each $50 \mathrm{c}$

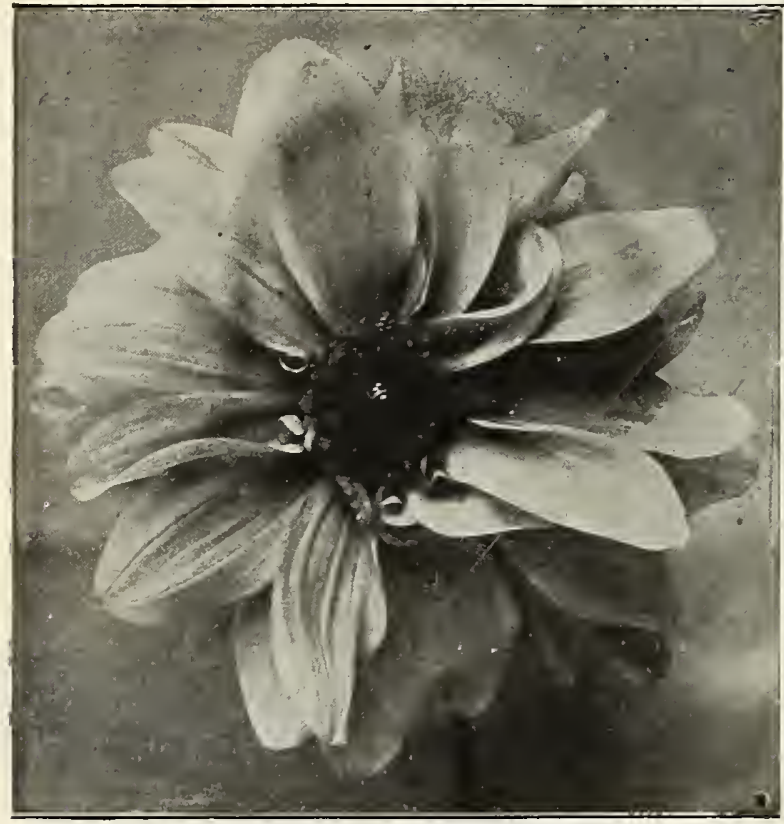

PEONY DAHLIA, QUEEN EMMA

Nymphaea.-One of the most delicately beautiful Dahlias ever introduced. Medium to large size, always full to the center resembling the ideal pink water-lily. The color is a clear distinct light shrimp-pink tinted lighter toward the center.

Perle d'Or..--(Perle du Parc de la Tete d' Or.) The grandest pure white Dacorative Dahlia. It is very large and free blooming.

SOUVENIR DE GUSTAVE DOAZON.-The largest Dahlia up to date; simply a monster, but still it impresses one with grace, beauty and elegance, and never fails to make friends. Color a rich scarlet.

SYLVIA.-The fine, shapely flowers, 5 inches across, are set on very long stems. Of fine form and full to the center, which is white shading to soft pink on the rim. PRICE: Any of the above, except where noted, each 15 c, dozen $\$ 1.50$

\section{PEONY DAHLIAS}

This new class of Dahlias has created a sensation at European flower shows, and was awarded high ho nors in England, France, Germany and Holland. The extra long, wiry stems are crowned with flowers composed of several rows of petals surrounding a conspicuous yellow disc. The petals are curiously curved, giving the flower the form of a semi-double peony. We predict a glorious future for this new type.

Queen Emma.-A magnificent sort, of a charming shade of mallow or Hollyhock pink, the inner petals banded with gold. Each $25 \mathrm{c}$, dozen $\$ 2.50$

CACTIS Thetals of this class are very long, pointed and beautiCAC UASLDS fully twisted. This type is at present most popular.

Countess of Lonsdale.-The most profuse bloomer among the Cactus varieties, and one of the very best. Beautiful salmon-pink; very large.

Floradora.-Beautiful, glistening scarlet-crimson; true cactus form, with fine pointed petals.

KRIEMHILDE.-Color fresh delicate pink, shading to white in center; perfect form, profuse bloomer. Stem is strong, holding flower up stiff, making it especially fine for cutting. Each $20 \mathrm{c}$, doz. 82.00 ROLAND VON BERLIN.-A magnificent brilliant Dahlia of large size, almost globular in form, made up of long, narrow petals. In color it is of an intense geranium-red, with deeper shadings, and full of fire.

Each 25c, dozen $\$ 2.50$

SCHWAN.-Absolutely the largest and most perfect, and besides the only free blooming pure white Cactus Dahlia in existence. The giant flowers are glistening white and by their narrow, twisted petals have an elegance which has not been approached by any other variety. Each 25c, dozen $\$ 2.50$

Strahlenkrone.- Intense cardinal red, rich and glowing, with long, twisted petals; early and profuse. Winsome.-Fine pure white Cactus; beautiful form, with twisted, incurved petals; long erect stems.

PRICE: Any of above Cactus, except when otherwise noted, strong field roots, each $15 \mathrm{c}$, dozen $\$ 1.50$ 


\section{SINGLE DAHLIAS}

Gold Standard.-Pure deep yellow, of large size; fine form and texture. The flowers are borne on long, graceful stems, in the greatest profusion; a strong, vigorous grower, and an early and continuous bloomer.

John Downic.-Intense, glowing crimson-scarlet. Snow Queen.-Best pure wnite.

Wildfire.-Clearest scarlet; very large and longstemmed.

Any of above Single Dahlias, strong field roots; each $15 \mathrm{c}$, dozen $\$ 1.50$

One each above 4 varieties for $50 \mathrm{c}$

\section{Twentieth Century Dahlia}

The most wonderful Dahlia ever introduced. It is impossible to correctly describe this exquisite variety. It must be seen that one may fully appreciate its marvelous beauty. The flowers are very large, 6 inches in diameter. The color is intense rosy crimson, with white tips and a white disk around the yellow center. As the season advances, the dark-colored zone becomes lighter and the color contrasts exquisitely lovely, and can be compared with no other flower than the beautiful orchid. The color of the Twentieth Century Dahlia does not fade, like that of many other flowers, but it is a case where each succeeding flower opens lighter and lighter as the season advances. Every week we really have a new flower.

Strong field roots, each 25c, dozen $\$ 2.50$

\section{COLLARETTE DAHLIA, PRESIDENT VIGER}

Rich, deep blood-red, shading darker towards the base of the petals, with pure white collar occasionally suffused with rosy carmine. The flow-

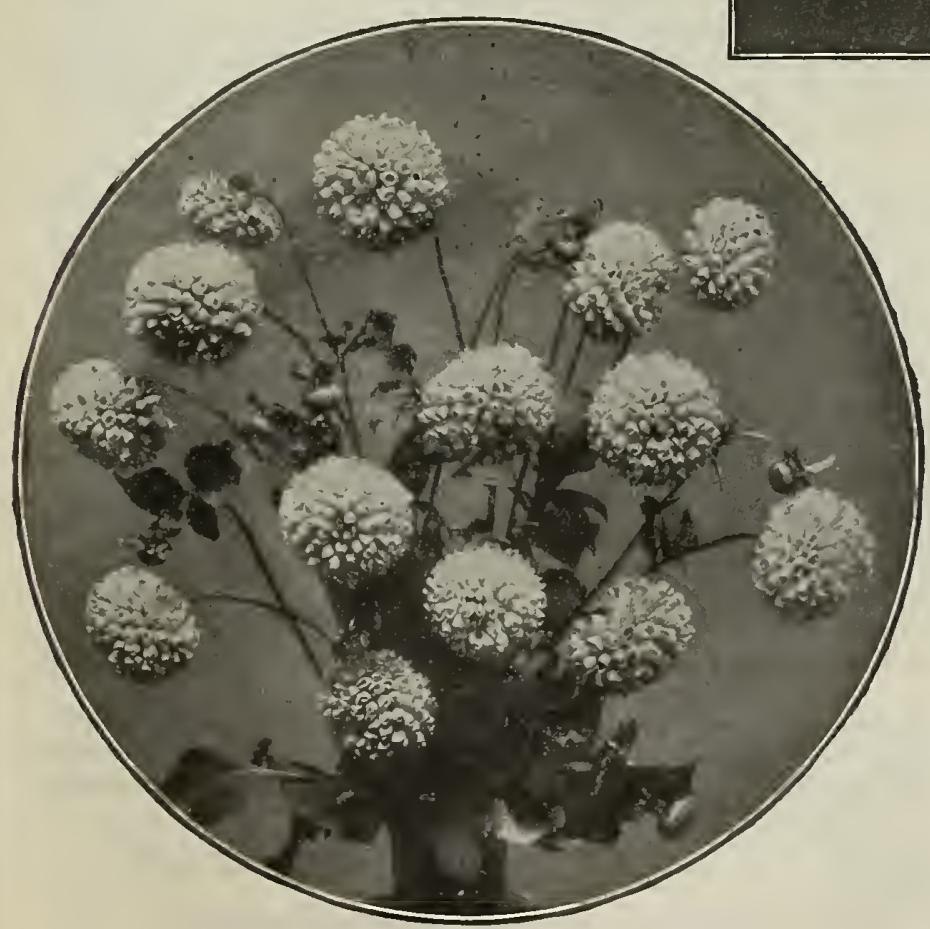

TWENTIETH CENTURY DAHLIAS

ers are always perfect, with eight petals, and it is an extremely early and profuse bloomer.

Strong field roots, each 20c, dozen $\$ 2.00$

\section{POMPON DAHLIAS}

Pompon Dablias are especially valuable for bouquets.

Allie Mourey.-A very pretty Pompon, of fine form and good habit; pinkish white tipped deep pink; small, compact flower.

Catherine.-The best pure yellow of fine form, full to the center, and borne on long stems.

Little Heien.-Extremely profuse strong grower; white, suffused blush.

Sunshine.-Brilliant scarlet; of fine form, with full centers and long stems; largely used for cutting.

Strong field roots, each $15 \mathrm{c}$, dozen $\$ 1.50$

TYPE OF POMPON DAHLIAS

Jne each above 4 sorts for $50 \mathrm{c}$ 


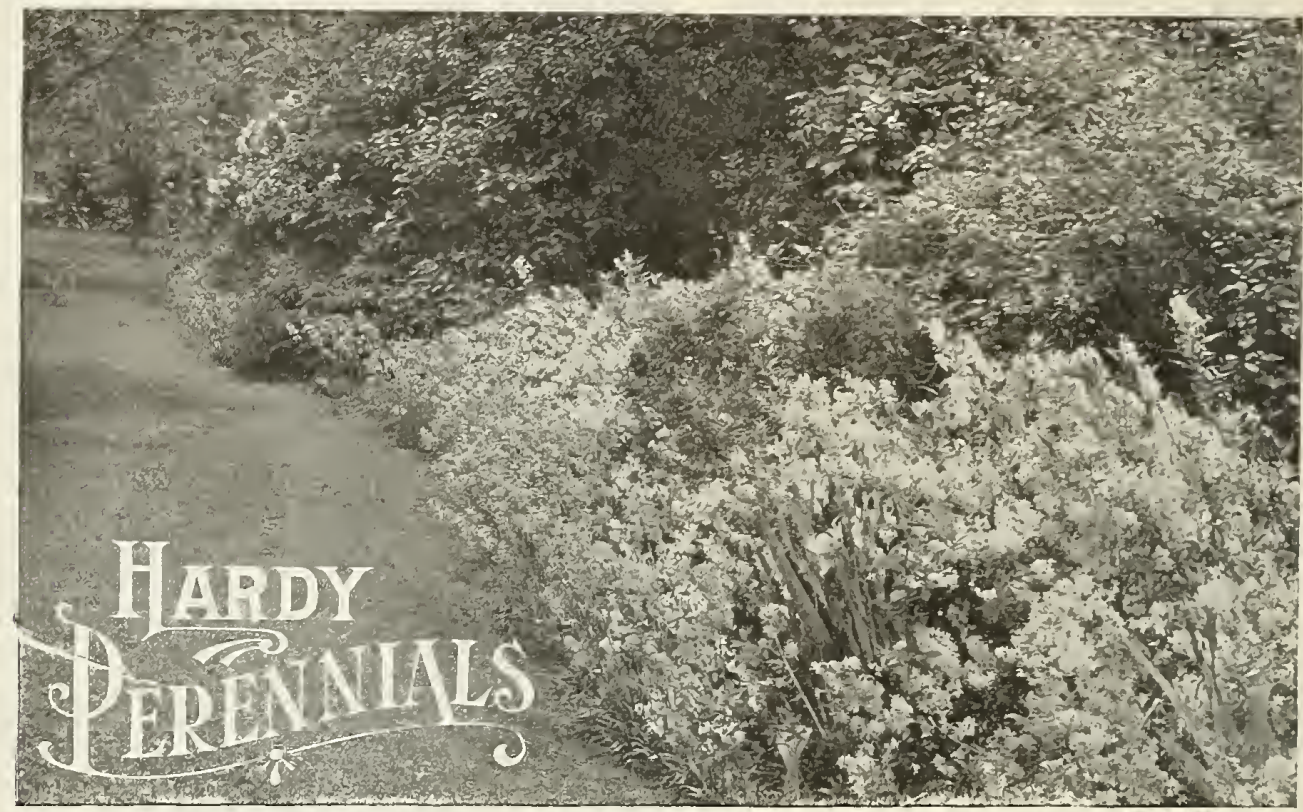

Nothing for the cost adds so much cheer to the home grounds, rendering them attractive and interesting throughout the growing season, as Hardy Perennial Plants. There is not a time during the whole flower season in which some hardy perennial is not in bloom, and a good selection of these plants will make the garden a source of unflagging interest.

A well-planned and well-planted garden of hardy plants begins its season with earliest spring, and almost every day something new comes into bloom, furnishing a constant variation so different from the monotony of formal beds. The hardy garden is never tiresome; its past is a plessantmemory, its future a delightful anticipation. Nothing is finer for borders, along fences or walls, and at the boundaries of the lawn. Planted at the front of shrubbery groups they give a brilliant display, and they are valuable in innumerable places that will suggest themselves.

They require the least possible care and attention, as when planted in well-enriched soil they live for years, annually increasing in size of plant and wealth of bloom. They need only a little stirring of the soil now and then during the early spring and summer months, with a fair mulching of coarse manure after the ground is frozen in the fall.

The Best Tall Perennials for Backgrounds

Asters, in variety

Boltonias

Bocconia cordata

Campanula pyramidalis

Digitalis

Helenium

Heli anthus, in variety

Hibiscus

Holly hocks

Larks pur

Physostegia

Pyrethrum uliginosum

Rudbeckia, Golden Glow

Yucca filamentosa

The Best Perennials with Fragrant Fiowers

Arabis alpina

Dianthus plumarius

Funkia subcordata

Hemerocallis flava

Hesperis matronalis

Lily of the Valley

Monarda didyma

Valeriana cfficinalis

\section{The Best Dwarf Perennials for Borders}

Alyssum saxatile

Anemone sylvestris

Arabis alpina

Aster alpinus

Bellis

Campanula carpatica

Funkia lancifolia

Funkia varieyata

Iberis sempervirens \& gibral.

Lily of the Valley

Myosotis

Primula auricula

Sedum acre

Tunica saxifraga

\section{The Best Perennials for Showy} Masses

Aster, in variety

Gaillardis grandiflora

Hollyhocks

Iris, in variety

Larkspur, in variety

Peonies

Phlox

Oriental Poppies
The Best Perennials for Cutting

Campanula, in variety

Coreopsis

Delphinium, in variety

Daisy, Shasta

Gaillardia grandiflora

Gypsophila paniculata

Helianthus, in variety

Heliopsis

Iris, in variety

Lily of the Valley

Peonies

Phlox

Rudbeckia, in variety

Tritoma

Veronica, in variety

The Best Perennials for Delicate Airy Effects

Delicately cut foliage and airy, small flowers are admirable for softening effect on bold masses.

Aquilegia, in variety

Boltonia

Gypsophila paniculata

Spirea

Thalictrum aquilegifolium 


\section{HARDY PERENNIAL PLANTS}

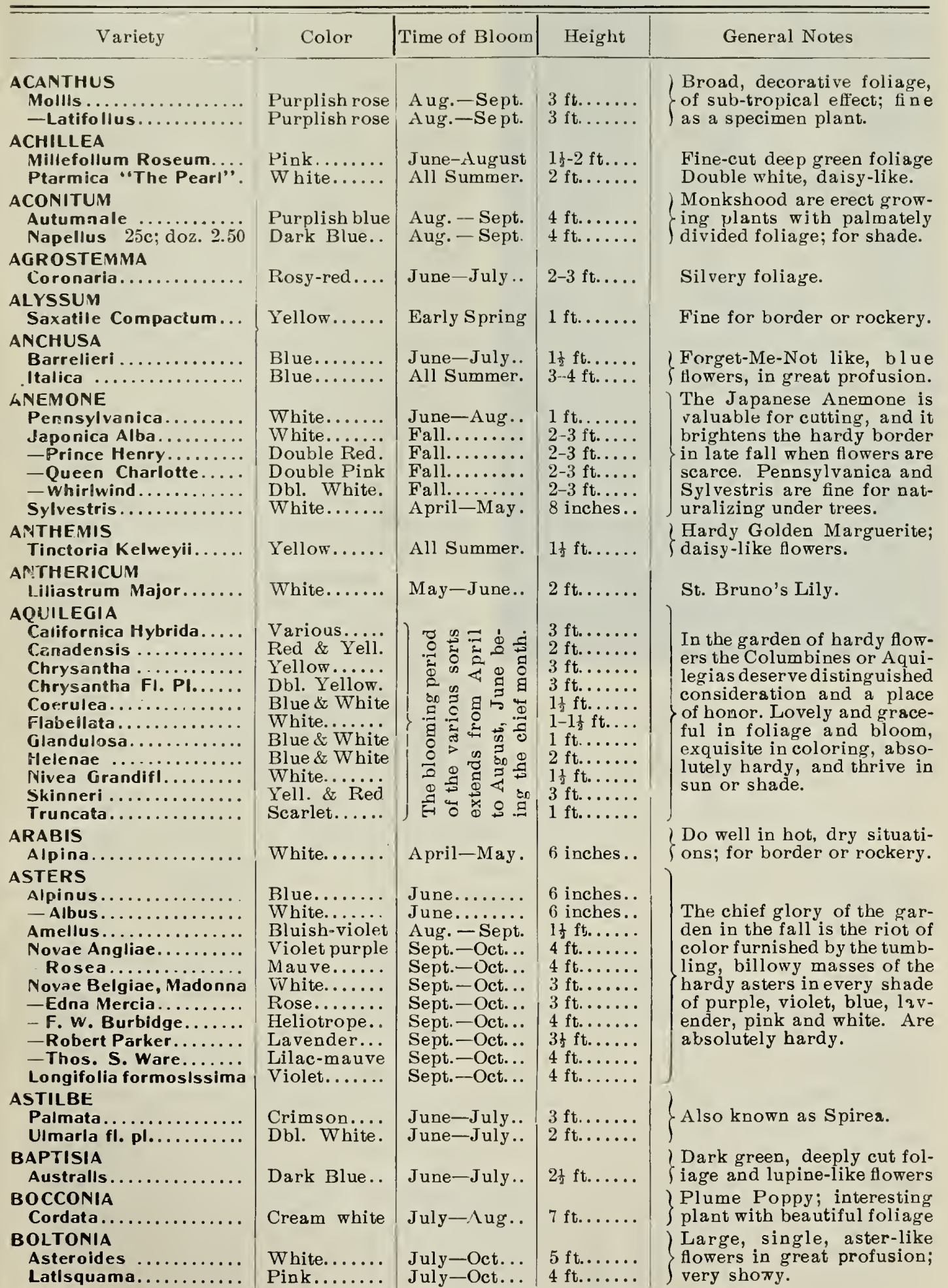

All Hardy Perennials, unless otherwise noted, 15c each, $\$ 1.50$ per dozen. 


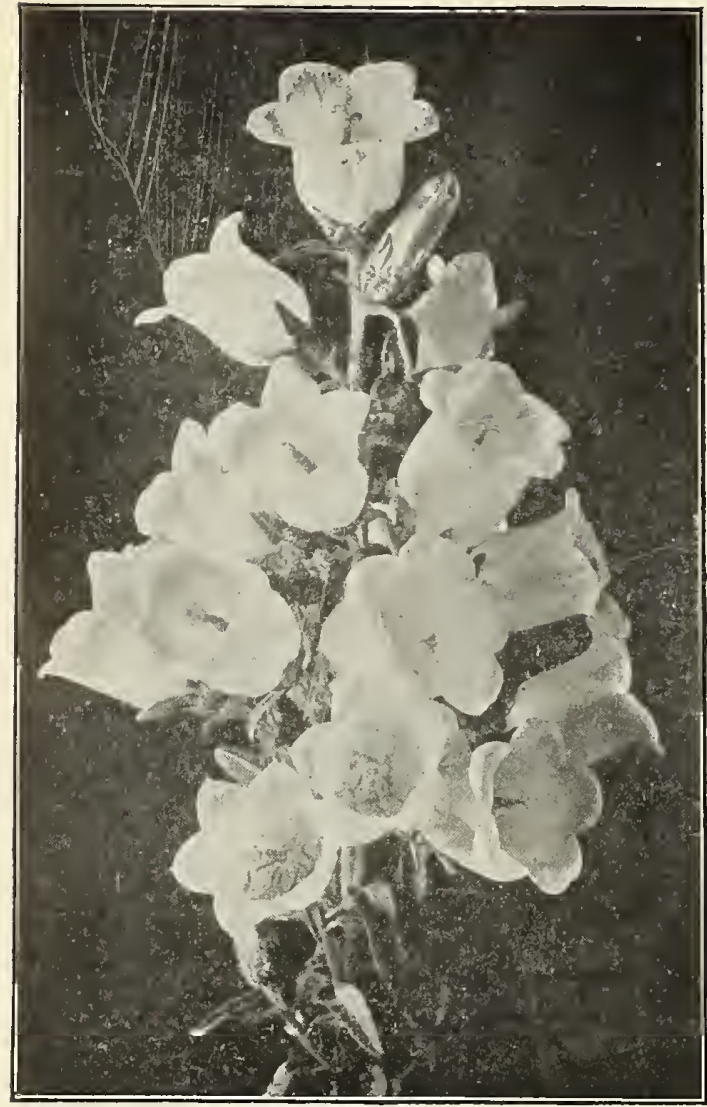

CAMPANULA MEDIUM

Daisy. S light pink with yellow center. Flossie. L silvery pink.

Julia Lagravere. L rich garnet.

Little Bob. P red. Rosy Morn. L rosy pink.

\section{CAMPANULAS Or BELLFLOWERS}

Nothing can surpass the grace of the clusters of delicate blue and white flower bells that distinguish the Campanulas or Bellfiowers. They are indispensable hardy plants, of much variety of form, some being of tall and imposing habit, while others are dwarf, compact little plants suitable for edging, rockworck, etc. The dominant color of this extensive and exquisite family is blue, but there are also white varieties and a few pink.

Carpatica (Carpathian Hare-bell). Clear blue, 8 inches high, fine for edging and rockeries.

-alba. White-flowered form of above.

Glomerata (Clustered Bell-flower). Dense clusters

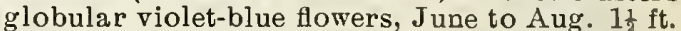

Grosseki. Dark blue flowers, all summer; 2 feet.

Latifolia macrantha. Purplish-blue, May to June.

Medium (Canterbury Bells). White, pink, blue, lilac and striped; June to August; 21 feet.

Medium Calycanthema (Cup and Saucer Canterbury Bells). White, pink blue, lilac, striped; $2 \frac{1}{2} \mathrm{ft}$.

Persicifolia (Peach Bells). Blue salver-shaped flowers during Juno and July. $1 \frac{1}{2}$ feet.

-alba. A white form of the above.

-grandiflora. Very large.

-Grosse Glocke. Extra.

Pyramidalis (Chimney Bell-flower). September; pyramid, 4 to 5 feet high, densely set with large salver-like blue flowers; very fine.

-alba. A white form of the above.

Rapunculoides. 3 feet; June-July; blue.

Rotundifolia (Blue Bells of Scotland). 1 foot.

Trachelium (Coventry Bells). 2-3 feet, purple.

Van Houttei. Blue; 2 feet; June to August.

\section{HARDY CHRYSANTHEMUMS}

As cut flowers these cannot be surpassed, coming at a season when all flowers are scarce, October and into November.

S stands for Single, P for Pompon, L for Large. Allentown. L golden brown.

Baby. P lemon-yellow.

Daybreak. L soft shrimp pink.

Gloire de France. L silvery pink.

King Henry. L sulphur white.

Sunshlne. P golden yellow. White Flora. $\mathrm{P}$ white. Each 20c, dozen $\$ 2.00$

\begin{tabular}{|c|c|c|c|c|}
\hline Variety & Color & Time of Bloom & Height & General Notes \\
\hline 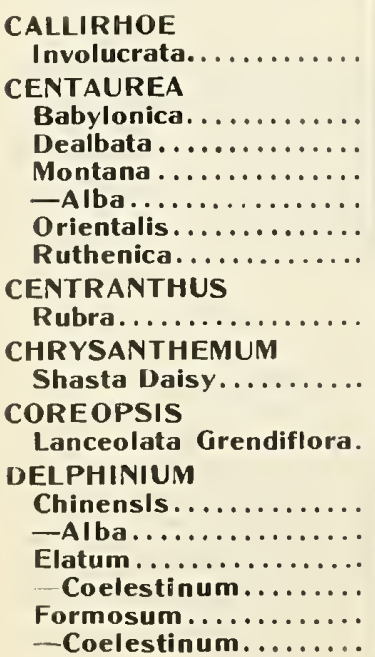 & $\begin{array}{l}\text { Rosy crimson } \\
\text { Yellow...... } \\
\text { Rose....... } \\
\text { Bluish-violet } \\
\text { White....... } \\
\text { Yellow...... } \\
\text { Straw Color } \\
\text { Dark Red... } \\
\text { White....... } \\
\text { Yellow...... } \\
\text { Blue........ } \\
\text { White...... } \\
\text { Blue....... } \\
\text { Light Blue.. } \\
\text { Dark Blue.. } \\
\text { Light Blue.. }\end{array}$ & $\begin{array}{l}\text { All Summer. } \\
\text { July-Aug.. } \\
\text { July-Sept.. } \\
\text { July-Sept.. } \\
\text { July-Sept.. } \\
\text { July-Aug.. } \\
\text { Aug. - Sept. } \\
\text { July......... } \\
\text { All Summer. }\end{array}$ & 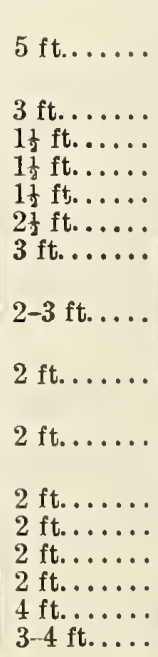 & $\begin{array}{l}\text { Centaureas or Hardy Corn- } \\
\text { flowers are desirable border } \\
\text { plants and good for cutting } \\
\text { Good for border and rock } \\
\text { garden. } \\
\text { Large snow-white flowers, } \\
\text { fine for cutting. } \\
\text { One mass of golden yellow } \\
\text { flowers, long graceful stems } \\
\text { The Larkspur or Delphini- } \\
\text { um is one of the loveliestof } \\
\text { all the tall blue-flowered } \\
\text { hardy perennials, running } \\
\text { through the whole gamut, } \\
\text { from palest sky tints to the } \\
\text { deepest purple. }\end{array}$ \\
\hline
\end{tabular}

All Hardy Perennials, unless otherwise noted, $15 \mathrm{c}$ each, $\$ 1.50$ per dozen. 


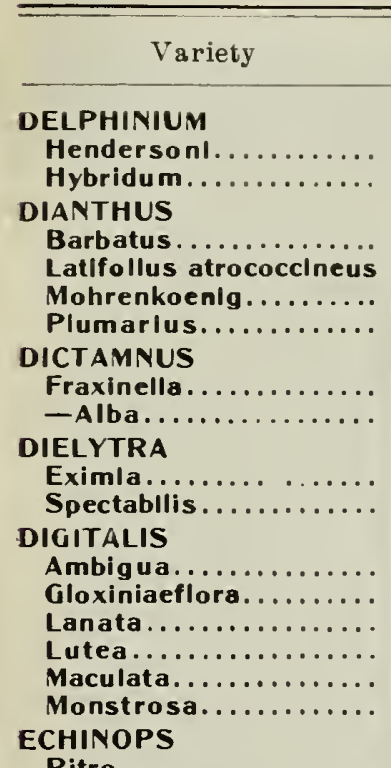

Ritro.................

Ruthenicus...........

Sphaerocephalus....... ERIGERON

Aurantlacus..........

Coulteri..............

ERYNGIUM

Planum

EULALIA

Graclllima............

Japonica Varlegata.....

-Zebrlna.............

EUPATORIUM

Ageratoides...........

Fraseri...............

FUNKIA

Lancifolla.............

Ovata ................

Sieboldiana...........

Subcordata.............

Undulata Var...........

GAILLARDIA

Grandiflora............

GALEGA

Officinalis

GERANIUM

Gravilleanum.

GEUM

Coccineum.

GYPSOPHILA

Paniculata.

HELENIUM

Autumnale Superbum.

Hoopesi.............

RIverton Beauty.......

RIverton Gem.........

HELIANTHUS

MaxImIllana...........

Miss Mellish...........

MultIflorus FI. PI.......

Orygalls..............

Perenne Hybrlda.......

Rigldus ..............

Solell d'Or............

\section{Color}

Dark Blue..

$V$ arious.....

Various.....

Crimson....

Dark Red...

Various.....

Pink........

White.......

Pink........

Pink..........

Yellow......

Various.....

Gray........

Yellow......

Yellow......

Various.....

Blue.......

Blue........

White......

Orange......

White.......

Blue....... July-Sept. .

White.......

White.......

Blue........

Purple........

Lilac........

W hite......

Purple.....

Blue........

Dark Red...

Scarlet......

White......

Yellow......

Orange.......

Lem on......

Terra Cotta.

Yellow......

Yellow......

Yellow......

Yellow......

Yellow......

Yellow......

Yellow......
July-Aug.

July-A ug. .

July-Aug..

July-A ug. .

July-Aug..

July-Aug. .

July-Aug..

July-Aug.

July-Aug..

July .

July .....

July-Sept. .

\section{Height}

4 ft. .

$3 \mathrm{ft} . . . .$.

$1 \frac{1}{2} \mathrm{ft} . . . .$.

$1 \frac{1}{2}$ ft......

$1 \frac{1}{2} \mathrm{ft} . . . .$.

$1 \mathrm{ft} . . . .$.

$2 \frac{1}{2} \mathrm{ft} . . .$.

$2 \frac{1}{2} \mathrm{ft} . . . .$.

$1 \mathrm{ft} . . . .$.

2 ft.........

$3 \mathrm{ft} . . . .$.

$4-5 \mathrm{ft} . . .$.

$2-3 \mathrm{ft} . . .$.

$2-3 \mathrm{ft} . .$.

2 ft......

3-4 ft....

$4 \mathrm{ft} . . . .$.

4 ft.......

$5 \mathrm{ft} . . . .$.

$2 \mathrm{ft} . . . .$.

$1 \frac{1}{2} \mathrm{ft} . . . .$.

$3 \mathrm{ft} . . . .$.

3-4 ft....

4-5 ft....

4-5 ft....

Aug.-Sept.

Aug.-Sept.

4 ft.......

$2 \mathrm{ft} . . . .$.

August......

August......

August......

August......

August......

$1 \mathrm{ft} . . . .$.

10 inches.

15 inches.

$1 \frac{\mathrm{ft} . . . .}{}$.

$1 \mathrm{ft} . . . .$.

All Summer.

2 ft......

July-Aug..

2 ft......

June-August

15 inches.

All Summer.

$1 \frac{1}{2} \mathrm{ft} . \ldots$.

July-Aug.

$2-3 \mathrm{ft}$.

Fall........

June-August

Fall.........

Fall.........

$5 \mathrm{ft} . . . .$.

2 ft.......

$3 \mathrm{ft} . . . .$.

$3 \mathrm{ft} . . . .$.

October..... 5-7 ft.... Sept. -Oct... 6 ft...... Aug.-Sept. $4 \mathrm{ft} . . . .$. Septem ber.. 6-7 ft.... Aug.-Sept. 5 ft...... July....... $3 \mathrm{ft} . . . .$. Aug.-Sept. $\quad 4-5 \mathrm{ft} . .$. .

\section{General Notes}

Bloom abundantly in midsummer, and later by cutting off the first spikes.

\section{Sweet William.}

Hybrid Everblooming S. W.

Old-fashioned Pinks.

Gas Plant. In hot weather, gives off a fragrant inflammable oil.

\section{Plumy Bleeding Heart.}

Bleeding Heart.

Foxgloves are popular oldfashioned plants. Ambigua is pale yellow veined brown Gloxiniæflora is a beautiful strain of finely spotted varieties, in white, rose, and purple.

Thistle-like plants having globular heads of flowers.

Fine for groups in the borCder.

Sea Holly.

Ornamental Grasses. Gracillima has nurrow green leaves with silvery midrib:

Zebrina striped across leaf.

Thoroughwort Fine for cut Dense heads of minute white flowers.

Plantain or Day Lilies have massive foliage, and lilylike flowers in terminal $\mathrm{ra}$ cemes. Effective in front of shrubbery, under trees, or any shaded position.

Orange, crimson and brown Valuable for cutting.

Goat's Rue; showy racemes of pea-shaped flowers.

Crane's Bill.

Useful border plant.

Baby's Breath. Gauze-like minute white Howers.

Sneeze-wort. Among the best of hardy perennials, blooming a long time.

Riverton Beauty and Gem, J each 25c, dozen $\$ 2.50$

Hardy Sunflowers. These are admirable for the hardy border or for planting with shrubbery. Multiflorus and Soleil d'Or are double flowering. Orygalis has long, willowy, drooping foliage. All are fine for cutting.

All Hardy Perennials, unless otherwise noted, $15 \mathrm{c}$ each, $\$ 1.50$ per dozen. 


\begin{tabular}{|c|c|c|c|c|}
\hline Variety & Color & Time of Bloom & Height & General Notes \\
\hline $\begin{array}{l}\text { HELIOPSIS } \\
\text { PItcheriana............. } \\
\text { Scabra Major........... } \\
\text { Soleil d'Or.......... }\end{array}$ & $\begin{array}{l}\text { Yellow...... } \\
\text { Orange..... } \\
\text { Yollow.... }\end{array}$ & $\begin{array}{l}\text { Summer..... } \\
\text { Summer..... } \\
\text { All Summer. }\end{array}$ & $\begin{array}{l}3 \mathrm{ft} . \ldots \ldots \\
3 \mathrm{ft} . \ldots \ldots \\
3 \mathrm{ft} . \ldots \ldots\end{array}$ & $\begin{array}{l}\text { Similar to Helianthus; ear- } \\
\text { lier and dwarfer. Fine for } \\
\text { cutting. Soleil d'Or is a } \\
\text { double form. }\end{array}$ \\
\hline 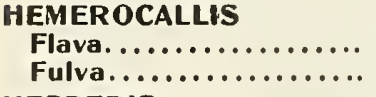 & $\begin{array}{l}\text { Lemon...... } \\
\text { Orange..... }\end{array}$ & $\begin{array}{l}\text { June-July.. } \\
\text { June-July .. }\end{array}$ & $\begin{array}{l}3 \mathrm{ft} . \ldots \ldots \\
4 \mathrm{ft} . \ldots \ldots\end{array}$ & $\begin{array}{l}\text { Yellow Day Lily. } \\
\text { Tawny Day Lily. }\end{array}$ \\
\hline $\begin{array}{l}\text { HESPERIS } \\
\text { Matronalis } \ldots \ldots \ldots \ldots \ldots\end{array}$ & Pink.. & June-July。. & $2 \mathrm{ft.}$. & Sweet Rocket. \\
\hline 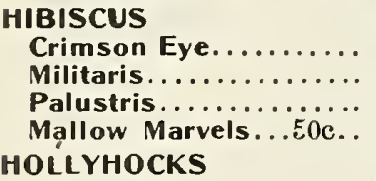 & $\begin{array}{l}\text { White........ } \\
\text { Pink....... } \\
\text { Pink....... } \\
\text { Various.... }\end{array}$ & $\begin{array}{l}\text { July-Sept.. } \\
\text { July-Sept.. } \\
\text { July-Sept.. } \\
\text { July-Sept. }\end{array}$ & $\begin{array}{l}4 \mathrm{ft} . \ldots \ldots \\
5 \mathrm{ft} . \ldots \ldots \\
4 \mathrm{ft} . \ldots \ldots \\
5 \mathrm{ft} . \ldots \ldots\end{array}$ & $\begin{array}{l}\text { Do best in damp situations. } \\
\text { Mallow Marvels are new } \\
\text { hybrids of immense size and } \\
\text { gorgeous colors; Crimson } \\
\text { Eye has bright red center. }\end{array}$ \\
\hline 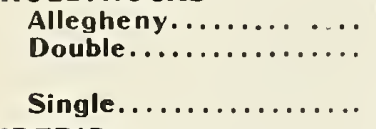 & $\begin{array}{l}\text { Various..... } \\
\text { Various..... } \\
\text { Various..... }\end{array}$ & $\begin{array}{l}\text { July-Aug.. } \\
\text { July-Aug.. } \\
\text { July-Aug.. }\end{array}$ & $\begin{array}{l}5 \mathrm{ft} . \ldots \ldots \\
5 \mathrm{ft} . \ldots \\
5 \mathrm{ft} . \ldots \ldots\end{array}$ & $\begin{array}{l}\text { Single and semi-double. } \\
\text { Salmon, scarlet, pink, white } \\
\text { maroon, lilac, brown, yell. } \\
\text { Mixed. }\end{array}$ \\
\hline $\begin{array}{l}\text { IBERIS } \\
\text { Gibraltarica........... } \\
\text { Sempervirens........ } \\
\text { INULA } \\
\text { Glandulosa Grandiflora. }\end{array}$ & $\begin{array}{l}\text { Lilac......... } \\
\text { White...... } \\
\text { Yellow...... }\end{array}$ & $\begin{array}{l}\text { May-June.. } \\
\text { May-June.. } \\
\text { June-August }\end{array}$ & $\begin{array}{l}10 \text { inches. } \\
10 \text { inches. } \\
2 \frac{1}{2} \mathrm{ft} . \ldots . .\end{array}$ & $\begin{array}{l}\text { The perennial Candytufts } \\
\text { form dense masses of pretty } \\
\text { evergreen foliage. } \\
\text { Fles Bane. Good for cut- } \\
\text { ting. }\end{array}$ \\
\hline
\end{tabular}

GERMAN IRIS. Under this head are included all the varieties of Iris Germanica and closely related species, with their many hybrid forms, and all their wonderful combinations of color. They are often called the "Orchids of the Garden"; and well they may be, for they outrival the orchid in the delicacy and wide range of their colors, which include richest yellows, softest blues and mauves, intense purples and claret reds, beautiful bronzes, and pure whites, in every conceivable combination. Nearly all have the irridescens of the rainbow, from which they are named. A dry, sunny location suits them best. Barely cover the rhizomes, and avoid fresh manure when planting. Should be divided and replanted every fourth year. $S$ indicates the erect petals or standards, $F$ the falls.

Admiral Togo. White, faintly tinted lavender; $F$ and S lightly bordered purple.

Asiatica. Very large; $\mathbf{S}$ pale blue, long rich purpleblue falls; late flowering.

Blue Bird. (Purple Queen). S and F rich violet-purple Canary Bird. S bright yellow, F deeper.

Celeste. 30 inches. S pale lavender; F deep lavender.

Comte de St. Clair. 30 inches. $\mathrm{S}$ and $\mathrm{F}$ white, with a wide blue border; a grand sort.

Cubero. S golden yellow, F yellow veined purple.

Darius. S rich canary yellow, F lilac margined white

Dr. Parnot. S blue; $\mathbf{F}$ violet, penciled white at base.

Florentina. $2 \mathrm{ft}$. Creamy white faintly flushed lavender

Florintina Alba. Pearly white, free flowering; 26 inch.

Gen. Grant. S pale lemon; F purple striped white on lower half, narrow edge lemon.

Herant. Very early. S bright blue, F deeper.

Honorabilis. S fine yellow, $\mathrm{F}$ maroon.

Lady Strump. S light blue; F dark blue.

L'Africaine. S rosy purple; F crimson, tipped white.

Madame Chereau. 32 inches. $S$ and $F$ white, daintily frilled with violet.

Mrs. C. Darwin. S white; F white, veined purple.

Pallida Dalmatica. $4 \mathrm{ft}$. S fine lavender, F clear deep lavender; large, sweet scented. 20c each, $\$ 2.00 \mathrm{doz}$.

Pallida Speciosa. S dark lavender, shaded lighter; $F$ shaded light purple; $3 \frac{1}{3} \mathrm{ft}$.

Paullne. $\mathrm{S}$ bright blue; F dark blue.

Pecutum. White, bordered light blue; tall and late.

Queen of May. S lovely light rose-lilac; falls lilac, blended white; beautiful. 28 inches.

Rebecca. S golden yellow; F yellow, veined brown.

Sans Souci. S golden, F crimson-brown; 20 inches.

Shakespeare. S straw-yellow veined with burnt umber; F deep carmine-violet. 26 inches.

Ulysses. S bright yellow, F yellow, veined white.

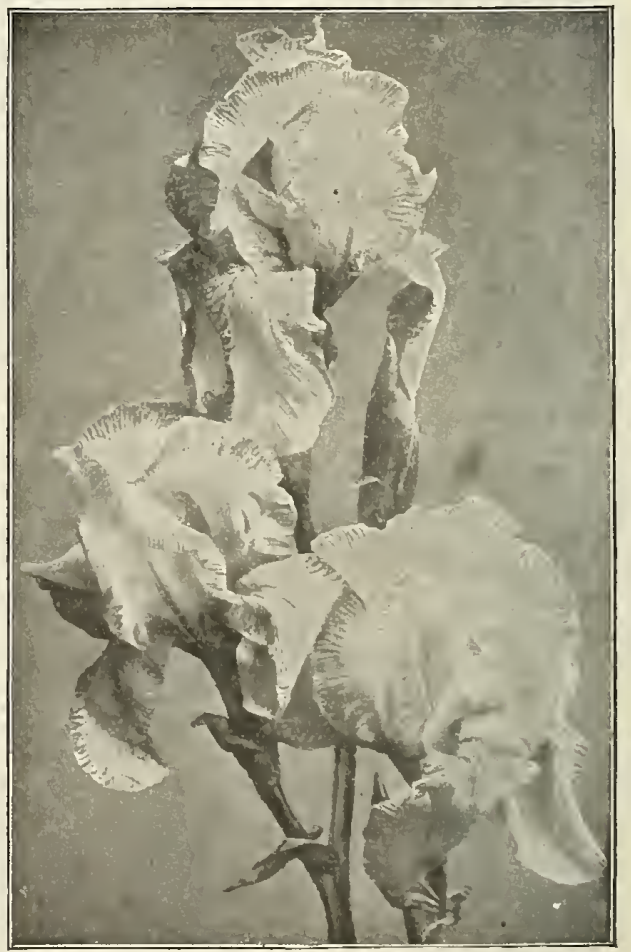

GERMAN IRIS, MADAME CHEREAU

All Hardy Perennials, unless otherwise noted, $15 \mathrm{c}$ each, $\$ 1.50$ per dozen. 


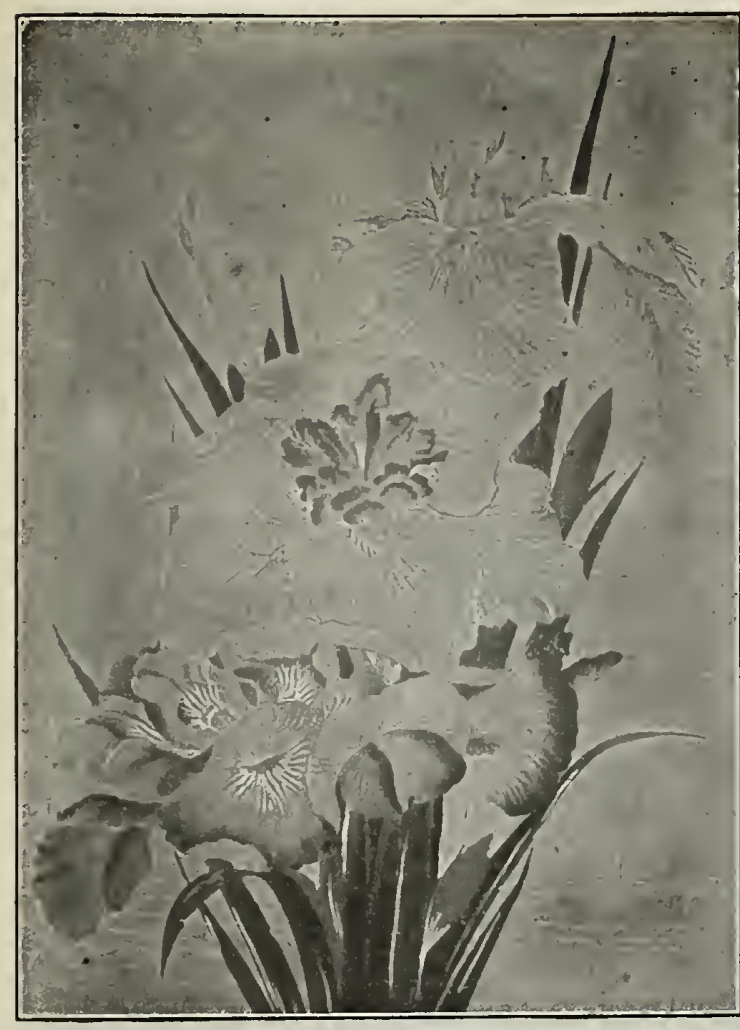

JAPANESE IRIS

All $\mathbf{J}$ apanese Iris, each $25 \mathrm{c}$, dozen $\$ 2.50$

\section{GERMAN IRIS-Continued}

Victory. $\mathrm{S}$ bronze; $\mathrm{F}$ violet, striped white, yellow at base.

Virgln. S pale lavender; $\mathbf{F}$ deep purple, veined white.

Zephyr. Sky-blue.

JAPANESE IRIS. Seeing these for the first time, one cannot withhold an exclamation of surprise and wonder, and having once seen, can never forget the striking beauty of this royal family, arrayed in richest purple and blue and gold. The secret of success is to keep the ground well stirred, never allowing it to bake or become hard. Any mellow loam will grow them to perfection, if well enriched. They like plenty of moisture in summer, but it is not a necessity, as many suppose, and water standing over the plants in winter is fatal to them.

Ada. Six petals; porcelain, thickly veined azure Bertha. Six petals; azure with white markings. Blue Beard. Three petals; violet plum.

Dagmar Georgeson. Three large drooping petals; rich royal purple.

Delicata. Six petals; pure white, suffused and veined rose.

Gold Bound. Six large open milk white petals, bound with golden yellow at base.

Navy Blue. Six petals; bright deep blue changing to Yale blue, gold band at center.

Mahogany. Nine long petals; rich maroon with soft luster.

Peacock. Nine petals; violet-purple veined with white.

Prof. Georgeson. Three very lsrge, rich violet petals,

Robt. Craig. Six fluted petals; white, veined rosy carmine.

Wm. Tell. Six petals; cobalt blue with distinct white rays, and white at center.

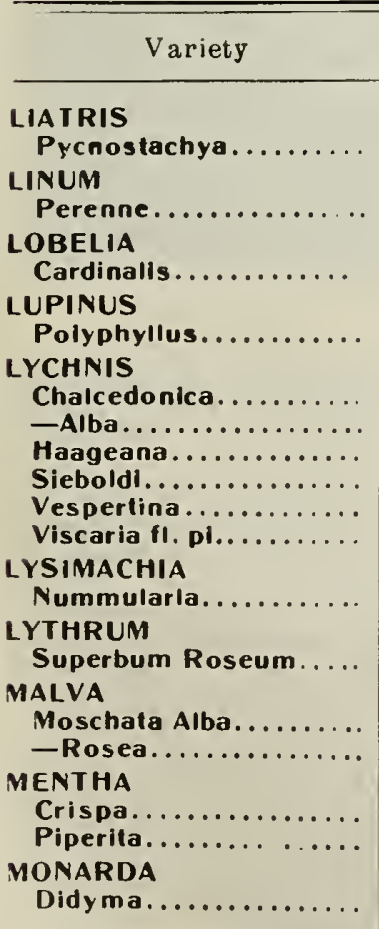

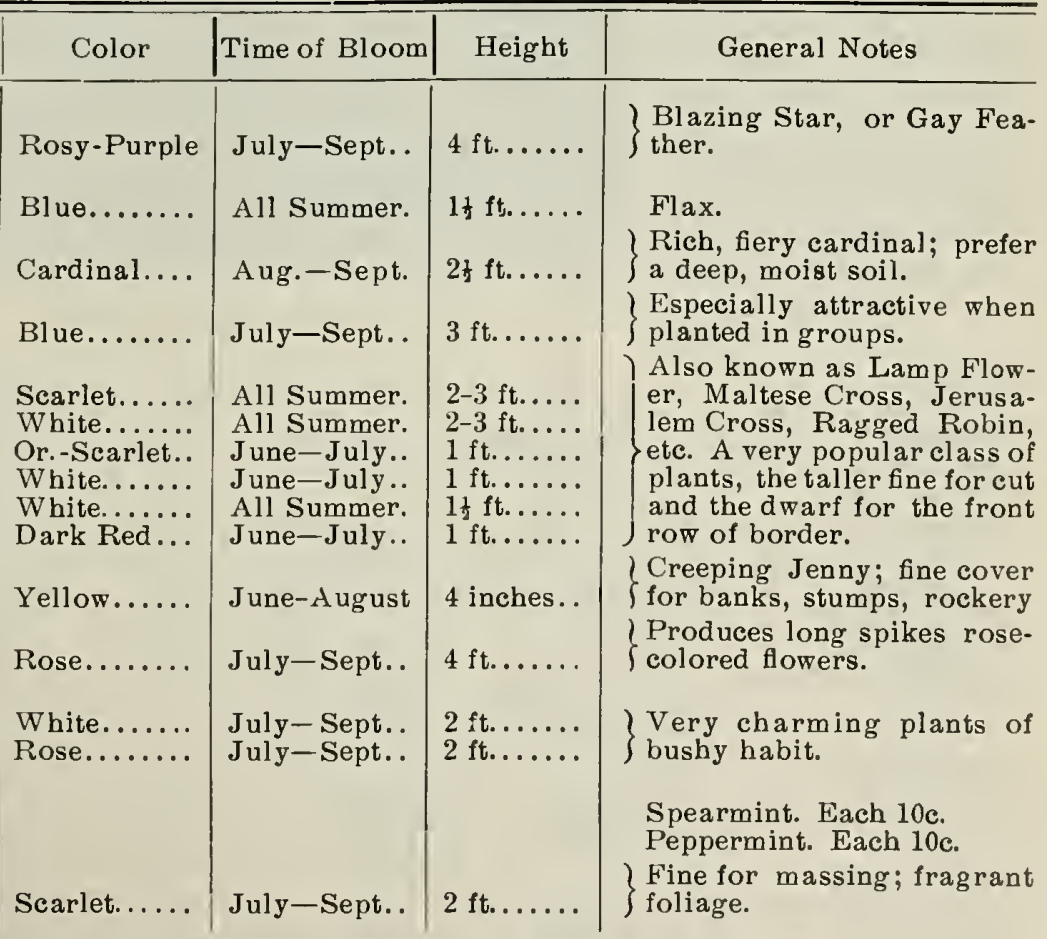

All Hardy Perennials, unless otherwise noted, $15 \mathrm{c}$ each, $\$ 1.50$ per dozen. 


\section{MYOSOTIS}

Alpestris. The large, sky blue, spring-flowering Forget-Me-Not. Ea. 10c

Palustris Semperflorens. Everblooming Forget-Me Not; fine for damp place spreading rapidly. 10c.

\section{OENOTHERA}

The Evening Primrose is good for massing in sunny positions, and blooms almost all summer; $1 \frac{1}{2} \mathrm{ft}$.

Fraseri. Rich yellow.

Speciosa. White.

Youngi. Bright yellow.

PARDANTHUS

Sinensis. Blackberry Lily. Orange.colored, lily-like flowers; $2 \frac{1}{2 t}$. ; July-Aug.

\section{PEONIES}

These great, big-hearted flowers of June are again coming into their own. Of truly regal magnificence, hardy as the oak, absolutely free of insect pests and disease, each year adding to size and beauty of the flowers, they are indeed worthy of a place in every garden.

Festiva Maxima. The finest white peony in existence; combines enormous size with wondrous beauty. Snow-white, with a few center petals flecked with

blood-red at the tips. Each 50c, dozen $\$ 5.00$

Grandiflora Alba. Large, perfectly formed, pure white flowers; very choice. Each $35 \mathrm{c}$, dozen $\$ 3.50$ L'Esperance. Lovely rose pink; large, fine form, delightfully fragrant; early. Each $35 c$, dozen $\$ 3.50$ Madam Calve. A large dark red, perfectly double; medium height, with good stem. $35 \mathrm{c}$, dozen $\$ 3.50$ Officinalis Rosea. Soft pink, very full, and the earliest pink one to bloom. Each $35 \mathrm{c}$, dozen $\$ 3.50$ Officinalis Rubra. The old-fashioned early deep crimson of our grandmothers' gardens, and still one of the best and most striking for landscape use. Large, globular blossoms. Each $35 \mathrm{c}$, dozen $\$ 3.50$

Prince Imperial. Very brilliant purplish-scarlet; large, full flower. Each $35 \mathrm{c}$, dozen $\$ 350$ Tenuifolia FI. PI. Rich crimson double flowers and fine feathery foliage; dwarf. $50 \mathrm{c}$, dozen $\$ 5.00$ Victoria Tricolor. Guard petals purplish-rose, center salmon-yellow, tipped white. 35c, dozen $\$ 3.50$

\begin{tabular}{|c|c|c|c|c|}
\hline Var & Color & Time of Bloom & Height & General Notes \\
\hline 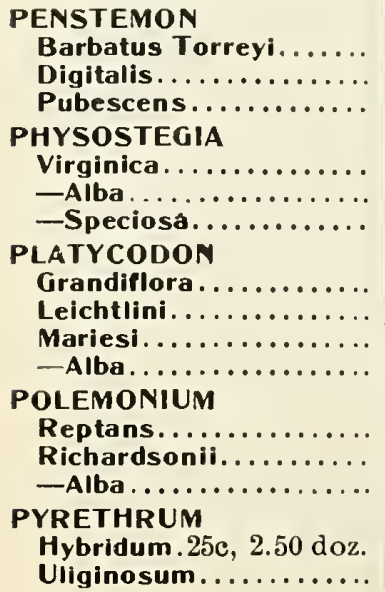 & $\begin{array}{l}\text { Scarlet...... } \\
\text { Purpli.-white } \\
\text { Rosy-Purple } \\
\text { Pink........ } \\
\text { White...... } \\
\text { Pink...... } \\
\text { Blue....... } \\
\text { Blue....... } \\
\text { Violet Blue. } \\
\text { White....... } \\
\text { Blue........ } \\
\text { Blue....... } \\
\text { White....... } \\
\text { White-Pink } \\
\text { White...... }\end{array}$ & $\begin{array}{l}\text { June-August } \\
\text { June-July.. } \\
\text { July-Aug.. } \\
\text { July-Sept. . } \\
\text { July-Sept.. } \\
\text { July-Sept. . } \\
\text { July-Aug.. } \\
\text { July-Aug.. } \\
\text { July-Aug.. } \\
\text { July-Aug. } \\
\text { June....... } \\
\text { June....... } \\
\text { June....... } \\
\text { June....... } \\
\text { Aug.-Oct... }\end{array}$ & 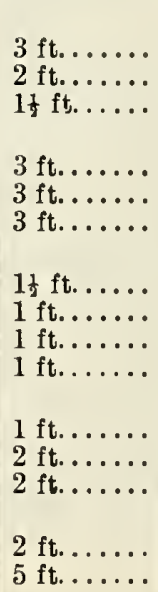 & $\begin{array}{l}\text { Long spikes of showy flow- } \\
\text { ers: useful for borders or } \\
\text { rockeries. Very free-flower- } \\
\text { ing. } \\
\text { False Dragon Head; spikes } \\
\text { of delicate tubular flowers, } \\
\text { not unlike a gigantic heath- } \\
\text { er. } \\
\text { V ery handsome plants of } \\
\text { the Campanula family, with } \\
\text { large open bell-shaped fiow- } \\
\text { ers, which in bud resemble a } \\
\text { balloon, hence the name. } \\
\text { Jacob's Ladder. Pretty bor- } \\
\text { der plant, with deep green, } \\
\text { fnely cut foliage and showy } \\
\text { spikes of blue and white. } \\
\text { Blooms similar to those of } \\
\text { the Hardy Aster. Splendid } \\
\text { for cutting. }\end{array}$ \\
\hline
\end{tabular}

All Hardy Perennials, unless otherwise noted, 15c each, $\$ 1.50$ per dozen. 


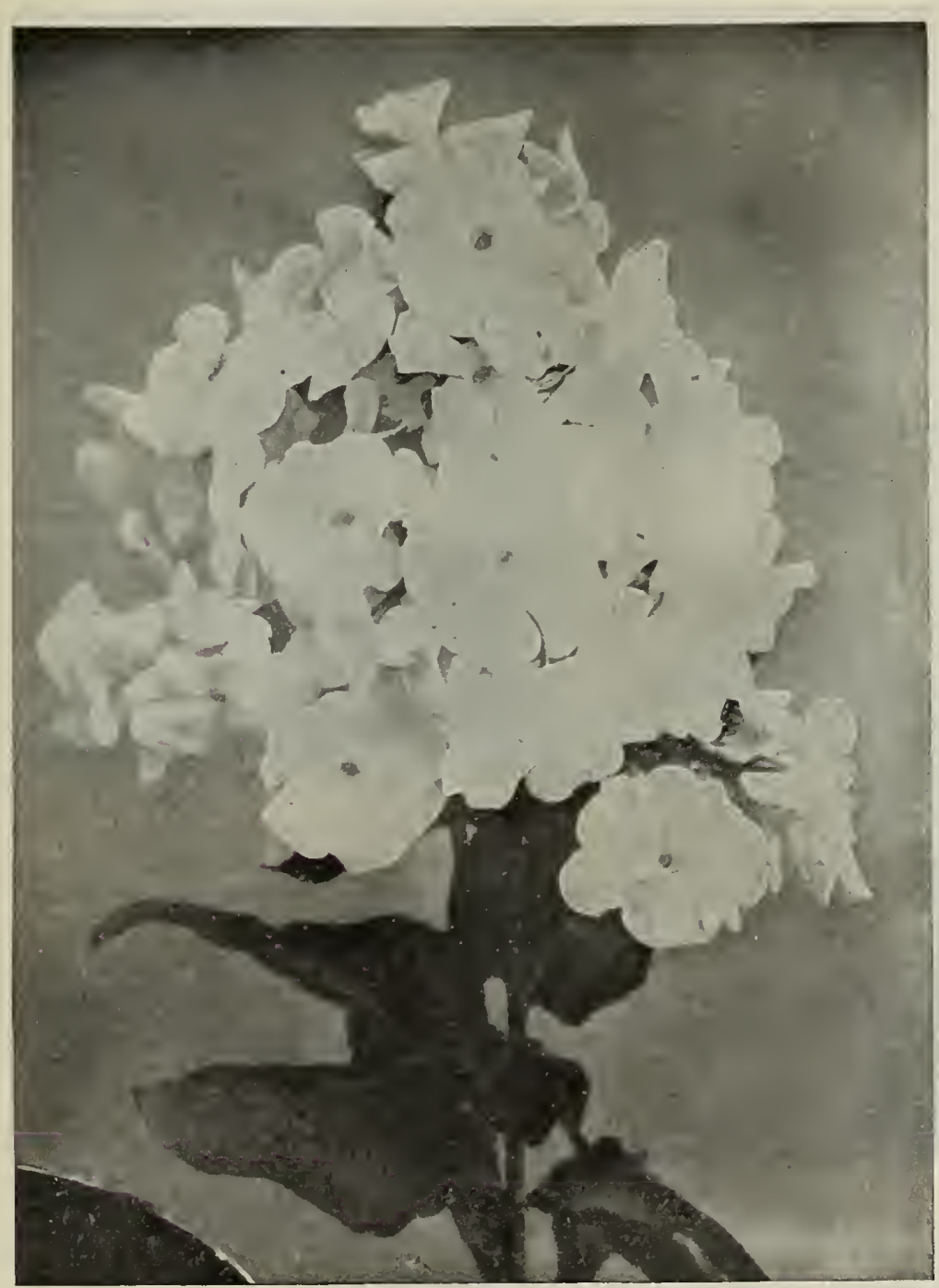

HARDY PHLOX
HARDY PHLOX

No flower has been more wonderfully improved of recent years, and the immensesize and perfect form of the newer varieties will be a revelation to those who have heretofore seen only old-fashioned kinds. From the purest white to delicate flesh and soft pink, through salmons and fiery scarlets the colors go to deep blood red and crimson, dark maroon, purple and amaranth. There are pale mauves and la venders soft lilac and deep violet. There are large white centers surrounded by rings of strong color, and soft delicate shades with vivid scarlet or crimson eye.

Phloxes are, next to the peonies and iris, the most. useful hardy plants which we have, and for late summer and autumn blooming they are indispensable. Effective either as single specimens, small groups, or large beds on the lawn. When massed against a background of shrubbery, they produce a beautiful and harmonious contrast.

They require a rich mellow soil to produce the best effect, for they are gross feeders. In dry seasons, water plentifully, for they like lots of moisture. Unlike most flowers, they will thrive in partial shade. where the colors are more brilliant and endure longer than in open sunlight.

We offer all the best varieties of phloxes, no inferior sort finding a place in our list. Our stock consists of strong field plants.

Alceste. White with large red eye; a tall grower.

Bachante. Enormous flowers, deep purple-carmine, with a purple eye.

Belvidere. Pure white; tall.

Beranger. Ground color white, delicately suffused with rosy pink; distinct crimson eye; early.

Bernice. Pure white; compact truss.

Bridesmaid. Pure white, with large crimson-carmine eye; very fine.

Caran d'Ache. Geranium red, with old rose shadings and white eye; very effective.

Cocquelicot. The most brilliant, fiery orange-scarlet, with crimson eye; one of the very best.

Eclaireur. Brilliant rosy magenta with large lighter halo; an excellent variety.

Frau von Lassburg. The purest snow-white; individual flowers larger than any other white; very fine Gloire de Saint Mark. Purplish-rose; very compact truss.

Henrl Murger. Flowers very large; pure white, with a large carmine center. One of the very finest. Huxley. White center with a broad lilac border; distinct.

Jeanne d'Arc. Absolutely snow-white; a very free bloomer; medium-sized flower and truss; late.

La Vague. Silvery rose. A large flower, and one of the best in our collection.

Le Soleil. Light rose, shading to white towards the center.

Lothair. Large flower of rich salmon color, with a crimson eye. Large, spreading truss.

Lumineaux. Extra large flower of soft rose, with a large carmine-blush center.

Mad. P. Langier. Deep rose with a crimson eye; very fine.

Montagnard. Dark crimson. Large, handsome truss and flowers, and one of the best dark varieties.

Mrs. Dwyer. Pure white, with a bright red eye.

All Hardy Perennials, unless otherwise noted, 15c each, $\$ 1.50$ per dozen. 


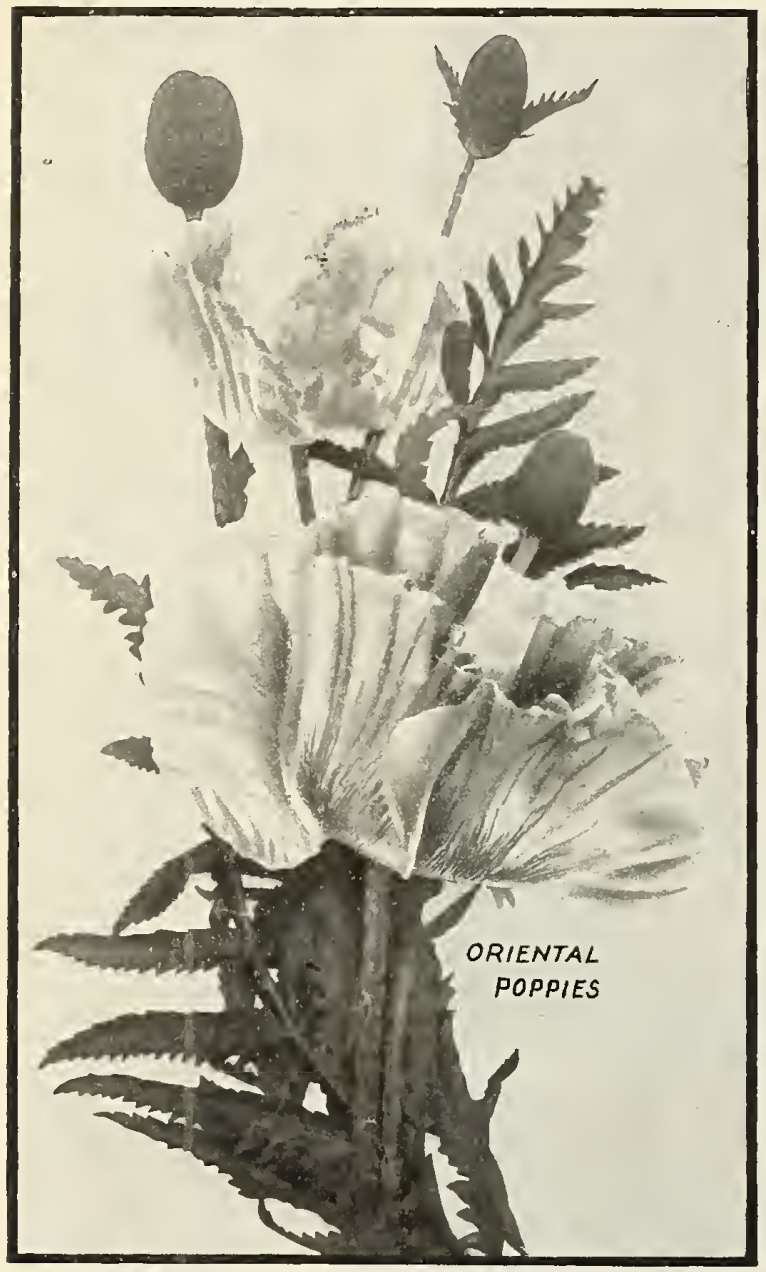

rays at center.

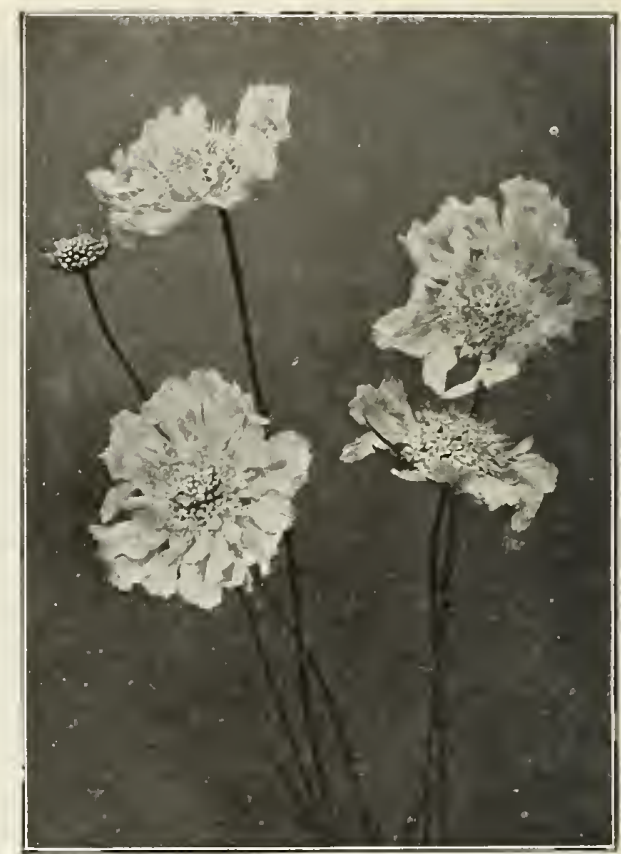

SCABIOSA CAUCASICA

HARDY PHLOX-Continued

Ornament. Bright clear rose, with light halo, darker center.

Pantheon. Beautiful large deep salmon-rose Prof. Schliemann. Mauve with crimson eye. Pyramidalis Alba. Pure white, very profuse. R. P. Struthers. Rosy carmine, claret eye.

Richard Wallace. Pure white, maroon cəuter. Thebaide. Carmine-lake.

Von Hochberg. The ideal crimson; the richest of its color.

EARLY PHLOX (SUFFRUTICOSA)

Beauty of Minion. Rosy lilac, with carmine Forward. White, with bright carmine eye.

Miss Lingard. A grand white variety with faint lilac eye. Begins blooming after the middle of June. For massing there is no finer white; extensively used for cut.

DWARF PHLOX (SUBUlata). Dense, prostrate habit: fine for borders and graves.

Alba. Pure white. Lilacina. Lilac. Rosea. Rosy pink. The Bride. White with bright pink center.

\begin{tabular}{|c|c|c|c|c|}
\hline Variety & Color & Time of Bloom & Height & General Notes \\
\hline 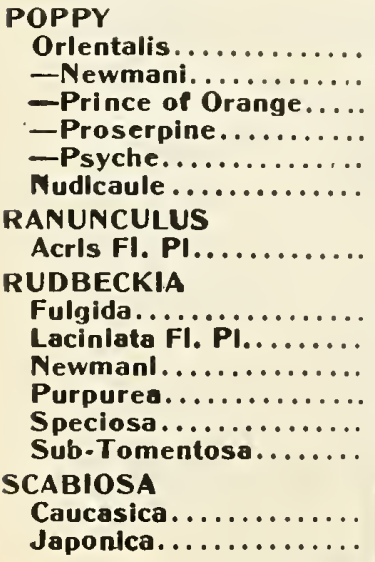 & $\begin{array}{l}\text { Or.-Scarlet.. } \\
\text { Dark Red... } \\
\text { Or.-Scarlet.. } \\
\text { Mauve... . } \\
\text { Rose........ } \\
\text { Various.... } \\
\text { Yellow...... } \\
\text { Orange...... } \\
\text { Yellow...... } \\
\text { Orange...... } \\
\text { Red-purple.. } \\
\text { Yellow...... } \\
\text { Lemon...... } \\
\\
\text { Lavender.... } \\
\text { Lavender... }\end{array}$ & $\begin{array}{l}\text { June....... } \\
\text { June........ } \\
\text { June....... } \\
\text { June....... } \\
\text { June....... } \\
\text { All Summer. } \\
\text { May-June.. } \\
\text { July-Sept.. } \\
\text { Aug._Oct... } \\
\text { July_Sept.. } \\
\text { July-Sept.. } \\
\text { July-Sept.. } \\
\text { Aug.-Oct... } \\
\text { June-Sept.. } \\
\text { Aug.-Oct... }\end{array}$ & 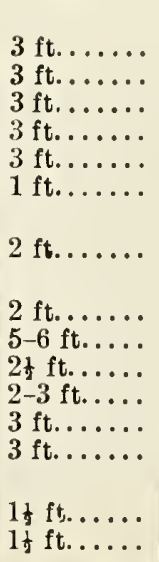 & $\begin{array}{l}\text { The largest poppies in the } \\
\text { world-six to eight inches } \\
\text { across-their blood red col- } \\
\text { or fires the imagination with } \\
\text { visions of the mystic Orient } \\
\text { Iceland Poppies; very free. } \\
\text { Bachelor's Button. } \\
\text { The Rudbeckias are very } \\
\text { decorative plants for shrub- } \\
\text { beries, borders, etc., and in } \\
\text { massing produce a grand } \\
\text { effect, besides offering fine } \\
\text { material for cut; Laciniata } \\
\text { is well-known Golden Glow } \\
\text { Soft, charming color. Fine } \\
\text { for cutting and for massing } \\
\text { They like sun. }\end{array}$ \\
\hline
\end{tabular}

All Hardy Perennials, unless otherwise noted, 15c each, $\$ 1.50$ per dozen. 


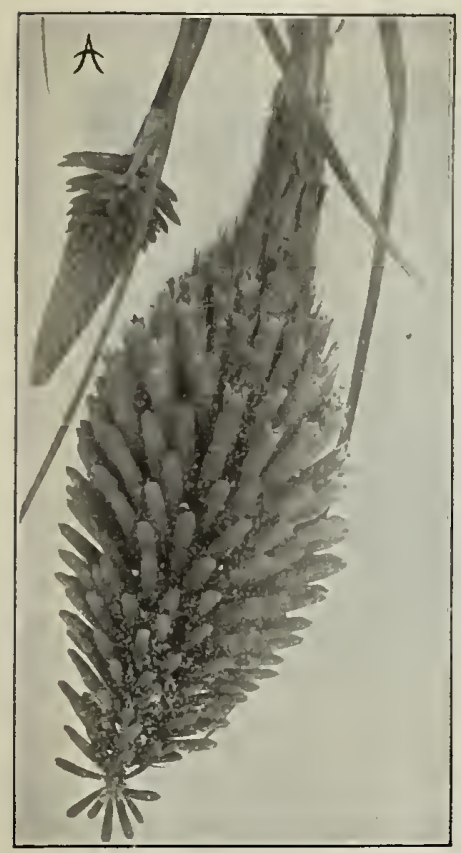

TRITOMA

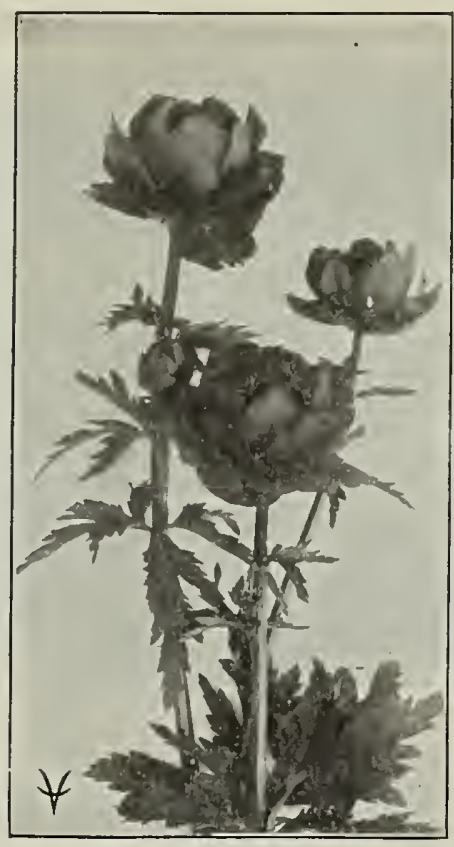

TROLLIUS

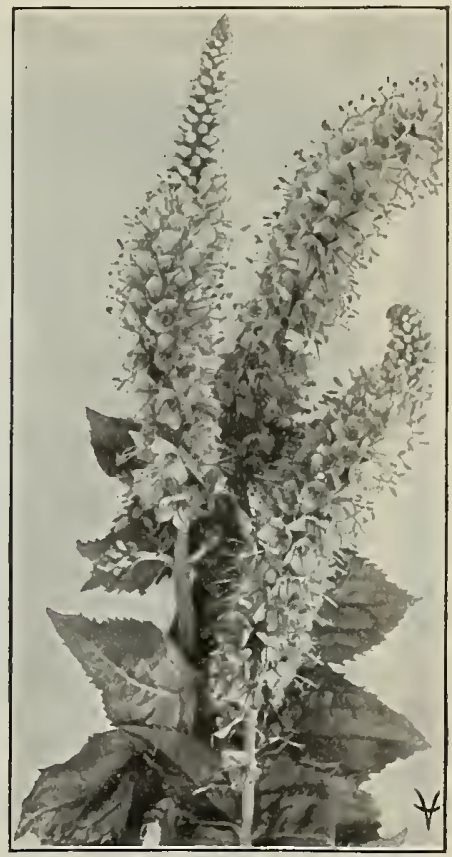

VERONICA

\begin{tabular}{|c|c|c|c|c|}
\hline Variety & Color & Time of Bloom & Height & General Notes \\
\hline $\begin{array}{l}\text { SALVIA } \\
\text { Azurea Grandiflora..... } \\
\text { Praten sis } \ldots \ldots \ldots \ldots \ldots\end{array}$ & $\begin{array}{l}\text { Sky-blue.... } \\
\text { Deep Blue... }\end{array}$ & $\begin{array}{l}\text { Aug.-Sept. } \\
\text { June-Sept. }\end{array}$ & $\begin{array}{l}3 \mathrm{ft} . \ldots \ldots \\
2-3 \mathrm{ft} . \ldots\end{array}$ & Meadow Sage. \\
\hline $\begin{array}{l}\text { SEDUM } \\
\text { Acre................. } \\
\text { Spectabilis } \ldots \ldots \ldots \ldots\end{array}$ & $\begin{array}{l}\text { Yellow ...... } \\
\text { Rosy-crimson }\end{array}$ & $\begin{array}{l}\text { May-June.. } \\
\text { Sept.-Oct... }\end{array}$ & $\begin{array}{l}4 \text { inches.. } \\
1 \frac{\mathrm{ft} . \ldots .}{}\end{array}$ & $\begin{array}{l}\text { Stone-crop; fine plants for } \\
\text { rock gardens, banks, and } \\
\text { walls. }\end{array}$ \\
\hline $\begin{array}{l}\text { SILENE } \\
\text { Alpestris ............. } \\
\text { Asterias Grandiflora... } \\
\text { Shafta............... }\end{array}$ & $\begin{array}{l}\text { White....... } \\
\text { Carmine..... } \\
\text { Pink....... }\end{array}$ & $\begin{array}{l}\text { July-Aug.. } \\
\text { July-Aug... } \\
\text { July-Sept.. }\end{array}$ & $\begin{array}{l}6 \text { inches.. } \\
3 \mathrm{ft} . \ldots . \\
6 \text { inches.. }\end{array}$ & Catchfiy. \\
\hline $\begin{array}{l}\text { STOKESIA } \\
\text { Cyanea. } \ldots \ldots \ldots \ldots \ldots \ldots \ldots \\
\text {-Alba } \ldots \ldots \ldots \ldots \ldots\end{array}$ & $\begin{array}{l}\text { Blue........ } \\
\text { White....... }\end{array}$ & $\begin{array}{l}\text { All Summ } \\
\text { All Summ }\end{array}$ & $\begin{array}{l}2 \mathrm{ft} . \ldots \ldots \\
2 \mathrm{ft} . \ldots \ldots\end{array}$ & $\begin{array}{l}\text { Cornflower Aster; showy, } \\
\text { aster-like flowers, } 4 \text { to } 5 \text { in- } \\
\text { ches across, fine for cutting }\end{array}$ \\
\hline $\begin{array}{l}\text { THALICTRUM } \\
\text { Adiantifollum ........... } \\
\text { Aquileglfolium........ }\end{array}$ & $\begin{array}{l}\text { Yello } \\
\text { Whit }\end{array}$ & $\begin{array}{l}\text { June......... } \\
\text { June-August }\end{array}$ & $\begin{array}{l}8 \text { inches.. } \\
2 \mathrm{ft} . \ldots .\end{array}$ & $\begin{array}{l}\text { The finely cut, graceful fol- } \\
\text { iage resembles that of the } \\
\text { Maiden-hair Fern. }\end{array}$ \\
\hline $\begin{array}{l}\text { TRADESCANTIA } \\
\text { Virglnica............. }\end{array}$ & Blue... & All Summer. & $2 \mathrm{ft}$. & Spiderwort. \\
\hline $\begin{array}{l}\text { TRITOMA } \\
\text { Pfitzerl................ } \\
\text { Uvaria Grandiflora...... }\end{array}$ & $\begin{array}{l}\text { Or.-Scarlet.. } \\
\text { Ochre-red... }\end{array}$ & $\begin{array}{l}\text { Aug.-Oct... } \\
\text { Aug.-Oct... }\end{array}$ & $\begin{array}{l}3 \mathrm{ft} . \\
4 \mathrm{ft} .\end{array}$ & $\begin{array}{l}\text { Red-hot Poker, Torch Lily, } \\
\text { or Flame Flower. Pfitzeri } \\
\text { is everblooming. }\end{array}$ \\
\hline $\left.\begin{array}{l}\text { TROLLIUS } \\
\text { Caucasicus } \\
\text { Europaeus }\end{array}\right\} \begin{array}{l}20 \mathrm{c} \mathrm{each} ; . . \\
2.00 \mathrm{doz} . .\end{array}$ & $\begin{array}{l}\text { Orange....... } \\
\text { Yellow..... }\end{array}$ & $\begin{array}{l}\text { May-June.. } \\
\text { May-June.. }\end{array}$ & $\begin{array}{l}2 \mathrm{ft} \\
2 \mathrm{ft}\end{array}$ & $\begin{array}{l}\text { Globe Flower; giant butter- } \\
\text { cup-like blossoms. Like a } \\
\text { moist situation. }\end{array}$ \\
\hline $\begin{array}{l}\text { TUNICA } \\
\text { Saxifraga......... }\end{array}$ & Lig & $\mathbf{J u}$ & & $\begin{array}{l}\text { Useful for rockery or bor- } \\
\text { der. }\end{array}$ \\
\hline $\begin{array}{l}\text { Valeriana, Officlnalls..... } \\
\text { VERONICA }\end{array}$ & Pink........ & June-July. . & $3 \mathrm{ft} . \ldots \ldots$ & Garden Heliotrope. \\
\hline $\begin{array}{l}\text { Amethystina............ } \\
\text { Incana................. } \\
\text { Longlfolla Subsessills.. } \\
\text { Repens................ } \\
\text { Splcata................ }\end{array}$ & $\begin{array}{l}\text { Amethyst... } \\
\text { Amethyst... } \\
\text { Blue....... } \\
\text { Blue........ } \\
\text { Blue....... }\end{array}$ & $\begin{array}{l}\text { July-Aug... } \\
\text { July-Aug.. } \\
\text { July-Aug.. } \\
\text { May--June.. } \\
\text { July ......... }\end{array}$ & $\begin{array}{l}2 \mathrm{ft} . \ldots \ldots \\
1 \mathrm{ft} \ldots \ldots \\
2 \frac{1}{2} \mathrm{ft} . \ldots \\
5 \text { inches. } \\
1 \frac{1}{2} \mathrm{ft} . \ldots \ldots\end{array}$ & $\begin{array}{l}\text { Among the prettiest of per- } \\
\text { ennials; Subsessilis is the } \\
\text { best of the tall sorts, and is } \\
\text { fine for cutting; Repens is a } \\
\text { trailing variety. }\end{array}$ \\
\hline $\begin{array}{l}\text { VINCA, MInor.......10c.. } \\
\text { YUCCA, FIlamentosa25c.. }\end{array}$ & $\begin{array}{l}\text { Blue......... } \\
\text { Cream-white. }\end{array}$ & $\begin{array}{l}\text { June......... } \\
\text { June-July.. }\end{array}$ & $\begin{array}{l}6 \text { inches.. } \\
4-5 \mathrm{ft} . . .\end{array}$ & $\begin{array}{l}\text { Periwinkle or Myrtle. } \\
\text { Adam's Needle. }\end{array}$ \\
\hline
\end{tabular}
All Hardy Perennials, unless otherwise noted, $15 \mathrm{c}$ each, $\$ 1.50$ per dozen. 


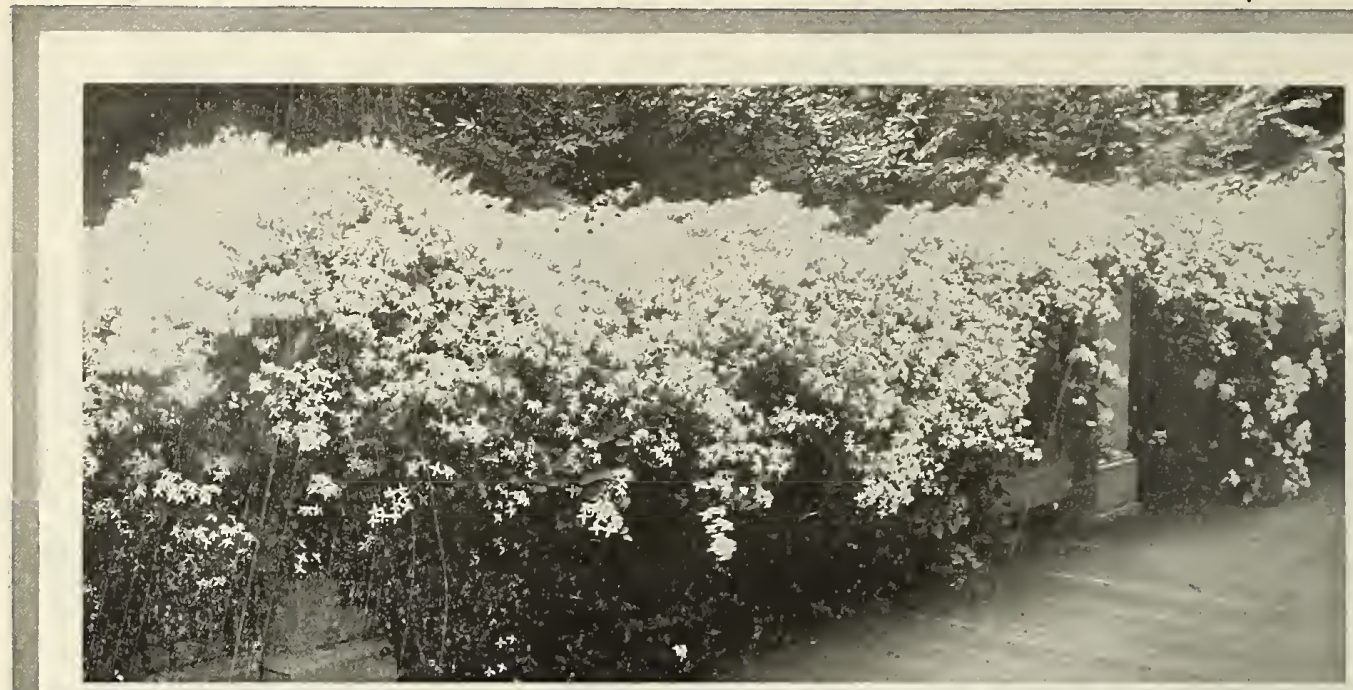

CLEMATIS PANICULATA-A 11 billowy with fragrant, feathery masses of white blossoms in september.

\section{Hardy Ornamental Climbing Vines}

There is no other class of plants that possesses quite so much grace and poetry as pretty trailing or climbing vines. It has been truly said that they are Nature's drapery. They add beauty and attractiveness to the plainest of dwellings, tone down the stiff, bold angles of new buildings, and should be lavishly trained over windows, porches and porticos, or wherever they will add finish and effect. Outhouses, as barns, henneries, etc., may be attractively covered and wuch that is inartistic concealed. They are nearly all strong, robust growers that require little attention other than to occasionally train them.

Ampelopsis Veitchii. Boston Ivy.-Very attractive climbing vine with glossy ivy leaves, closely overlapping. The tendrils cling firmly to the smoothest surface. In a utumn the leaves assume the most beautiful tints of scarlet and crimson. $\quad 3$ year old, each 35c, dozen $\$ 3.50,100 \$ 22.50$ AMPELOPSIS QUINQUEFOLIA.-Virginia Creeper. Splendid for covering trees, arbors and trellises. The large deep green foliage assumes brilliant shades of yellow, crimson and scarlet in fall.

2 year old, each $25 \mathrm{c}$, doz. $\$ 2.50$

Ampelopsis Engelmannl. (Engelman's Ivy.) One of the hardiest, best and quickest growing climbers for the north and northwest. Quite similar to the Virginia Creeper, but vastly superior to it, the foilage being cleaner, of greater substance, and not turning yellow during the early fall, and almost perfectly free from insects. The leaves color up beautifully in the fall 2 year old, $25 \mathrm{c}$; dozen, \$2.50.

ARISTOLOCHIA SIPHO.--Dutchman's Pipe. A strong, rapid growing, tropical-looking vine with handsome light green leaves, 8 to 12 inches across. It will give a quick dense shade. The corolla of the brown flowers is shaped like the bowl of a pipe. Large vines, 6 to 8 feet, each $50 \mathrm{c}$, dozen $\$ 5$. 00

BIGNONIA.-Trumpet Vine. These are familiar, strong-growing vines, with deep, rich green foliage and large, trumpet-shaped, orange-scarlet flowers in early summer. 3 year, each $35 \mathrm{c}$, doz. $\$ 3.50$

Large Flowering Clematis. The most beautiful class of flowering climbers. For covering verandas, pillars, trellises, etc. there is nothing to compare with the Clematis in splendor of bloom. Plant in good garden soil, dug very deeply, placing the crown inches below the surface. Apply well-rotted manure in post holes bored 12 inches away from the plant in opposite directions. The roots reach out to these holes, which may be watered freely, and better success is obtained than by applying the manure directly to the base of the plants.

Henryi.-Flowers always eight-sepaled, very large, pure white.

Jackmani.-Rich, deep velvety purple. Blooms with astonishing profusion.

Strong 2 year old roots, each 50c, dozen $\$ 5.00$. Extra strong 3 year old roots, each $75 \mathrm{c}$, dozen $\$ 7.50$ Clematis Paniculata.-This is by far the best of all the Clematis of the small flowering class. Of very rapid growth, with small, dense, glossy green foliage. The flowers are pure white, borne in immense sheets, almost completely hiding the foliage, and of a most delicious fragrance. Flowers in September. 2 year, each $25 \mathrm{c}$, dozen $\$ 2.50$; 3 year, each $35 \mathrm{c}$, doz. $\$ 3.50 ; 4$ year, each 50 c, doz. $\$ 5.00$ 


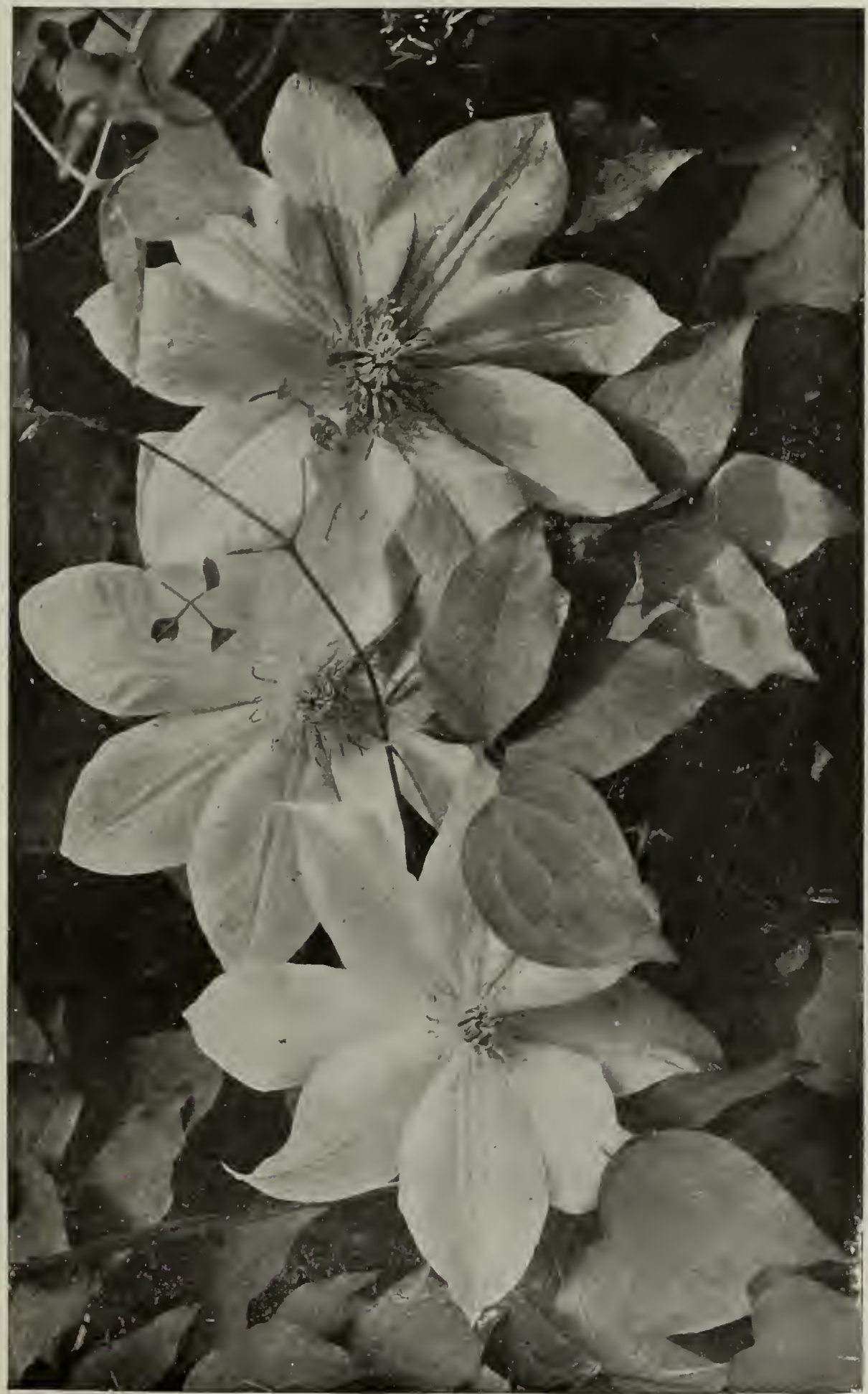


W. E. DALLWIG 34-Juneau Ave. MILWAUKEE है

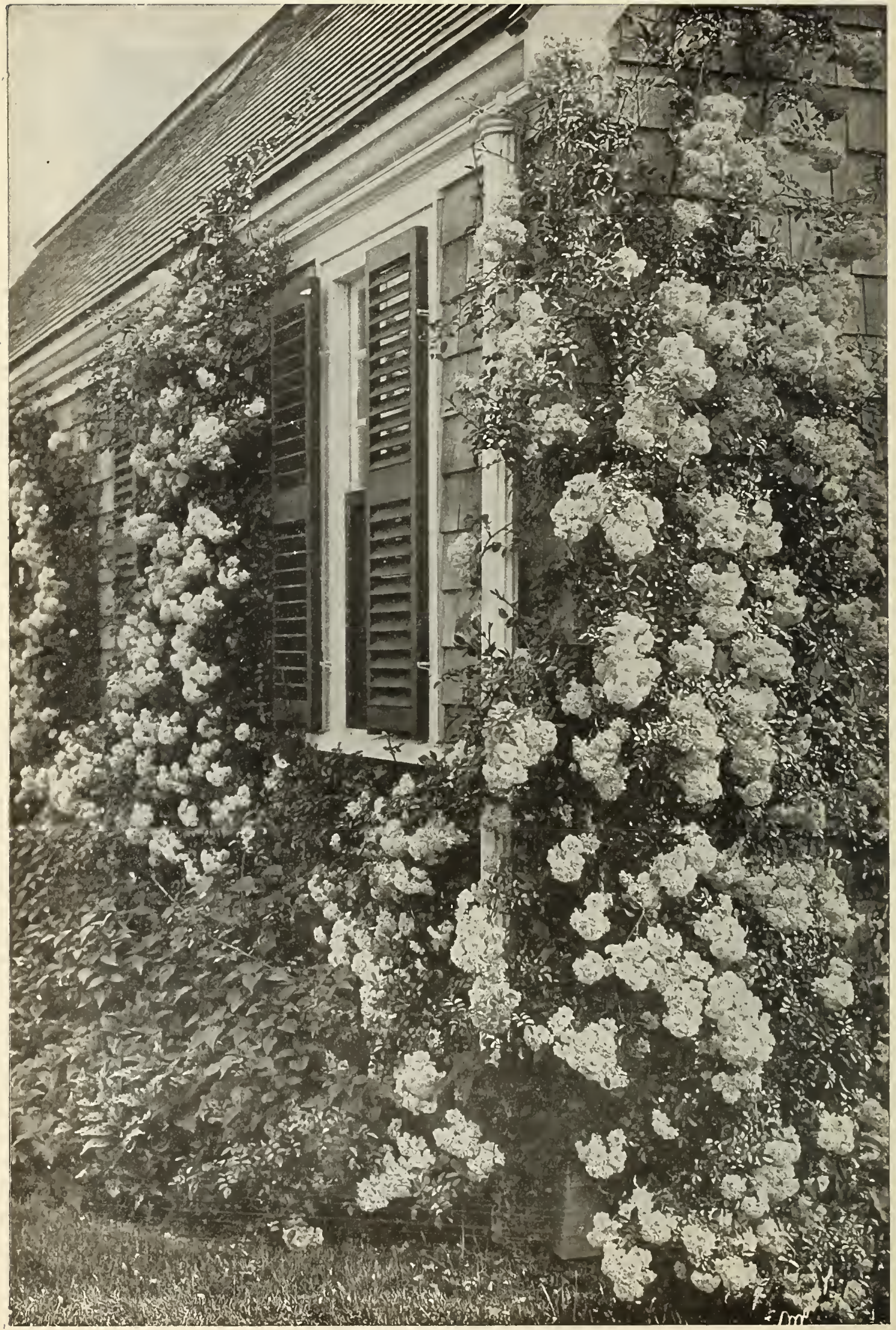




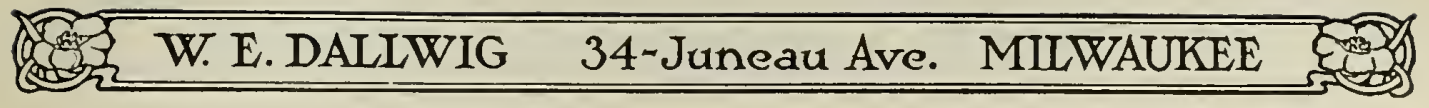

CLEMATIS COCCINEA.-Bell-shaped flowers of a bright coral-red color. 2-year-old plants, each 25c, doz. $\$ 2.50$ HONEYSUCKLE. Scarlet Trumpet.-Produces

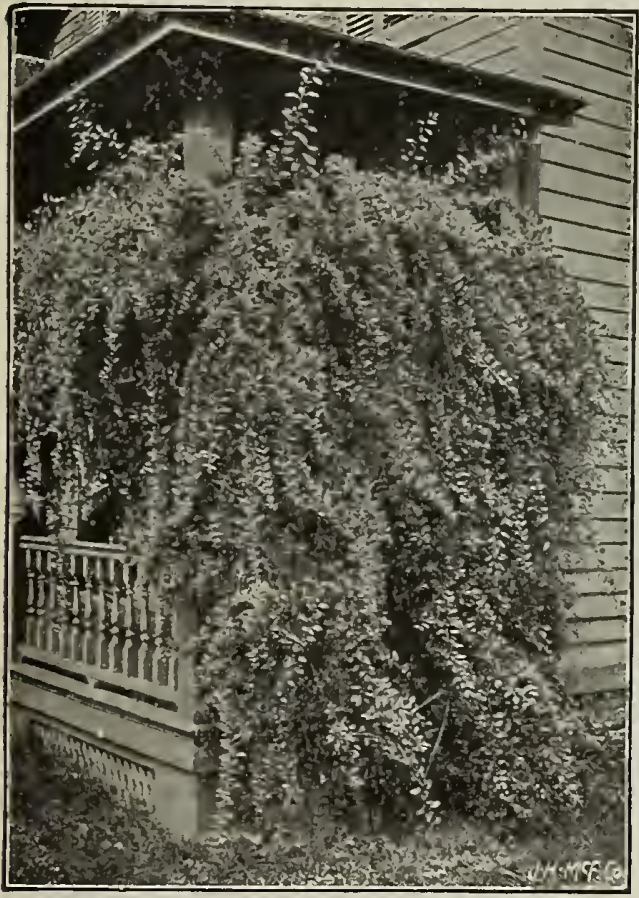

MATRIMONY VINE.
CLEMATIS COCCINEA.

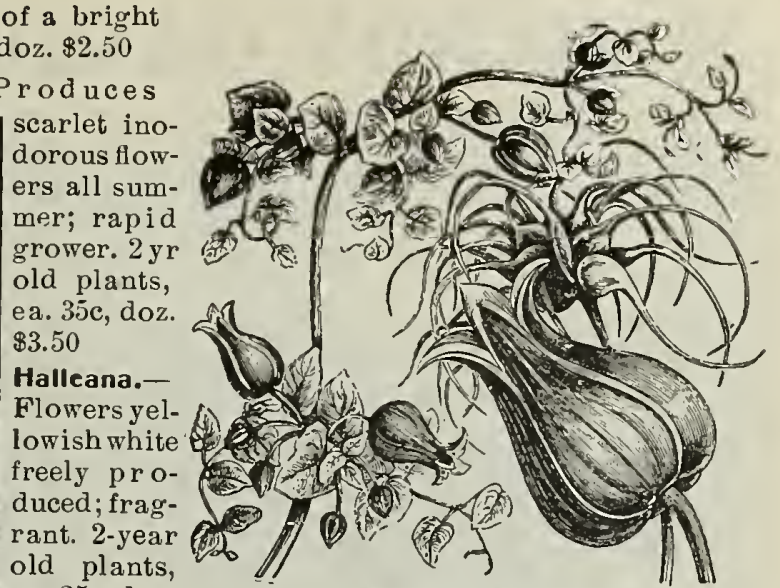
ea 250, $\$ 2.50$

Kudzu Vine or Jack-and-the-Bean-Stalk. - This is the most rapid climber, attaining after once established a height of 50 feet or more in a season. Large foliage, clusters of Wistaria-like blossoms. Each 35c

Matrimony Vine.-Well-known, hardy, rapid climber; covered with scarlet fruit in autumn.

Extra heavy 2-year-old vines, each $35 \mathrm{c}$

CHINESE WISTARIA.- One of the best of all hardy climbers. It grows rapidly and presents a magnificent appearance with its pendulous clusters of pale blue.

2-year-old vines, each $50 \mathrm{c}$

Vitis-Grape. $v$. he terophylla variegata.-The delicate markings and beautiful form of the variegated leaved Grape endears it to all plant lovers. The foliage is deeply cut and is very decorative. Has highly attractive berries.

3 year old, each $35 \mathrm{c}$, dozen $\$ 3.50$

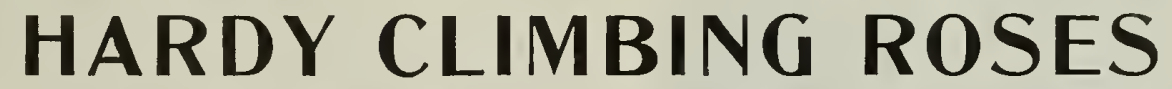

Crimson Rambler. - Unquestionably one of the finest roses in existence. A vigorous grower Cring shoots 10 to 15 feet in a single season, and when in bloom comolossoms, produced in cluster in marvelous abundance. May be grown on verandas, pillars, fences and walls, or it can be grown in bush form and thus becomes a most striking object.

Extra Select, with canes $3 \frac{1}{2}$ to 4 feet, each 35 c. doz. $\$ 3.50 \quad$ Select, 2 to 3 ft., each 25 c. doz. $\$ 2.50$ Yellow Rambler.-Flowers in clusters of 6-10. Yellow in the bud, but nearly white when fully open. Dorothy Perkins. - In foliage and habit of growth it is remarkably like Crimson Rambler; the twenty, the clusters being borne in racemes of three to five, thus often making a group containing fifty to sixty blossoms upon a single stem. The petals are very prettily rolled back and crinkled. The color is a clear shell pink and holds a long time without fading; very sweetly scented.

Prairie Queen.--liright rosy red, large flowers $\quad$ 2-year-old planis, each $35 \mathrm{c}$, dozen $\$ 3.5 n$

Prai-ie Queen.-Hright rosy red, large flowers. A favorite with everyone.
2 -year-old plants, each 25 c, dozen $\$ 2.50$

ausendschoen.-Raised by severul crossings between the well-known Crimson Rambler, Tea and Poly antha Roses. This beautiful novelty surpasses all other climbing roses of this section, both in growth of foliage and beauty of blooms. The flowers appear in large clusters from the beginning of June till the end of July. Each individual flower measures about 2 inches across and is of a beautiful soft pink, same color as Clothilde Soupert; later on changes into rose-carmine. The plant is of strong, vigorous growth, absolutely hardy, and a most excellent variety to plant wherever a strong: climber is desired. Very agreeable, as it is nearly thornless.

2-year-olr plants, each $35 \mathrm{c}$, dozen $\$ 3.50$ MEMORIAL OR EVERGREEN ROSES.-(Rosa Wichuraiana). The ty pe of this group of roses, Rosa Wichuraiana, is of Japanese origin, and flowers during June and July. They are ef a trailing habit of growth, very hardy, and are recommended for covering graves, hence one of ils names Memorial Rose, climbing over walls, arbors, stumps of trees or for trailing over rocks or rough ground. The foliage is of a leathery texture, of a beautiful shining green, proof against all insects, and is retained on the nlants almost the entire winter. 2-year-cld plants, each $25 \mathrm{c}$, dozen $\$ 2.50$ 


\section{HARDY GARDEN ROSES}

The beauty of the Rose is so widely appreciated that the popularity it now enjoys is annually increasing. In old-fashioned gardens, in borders, along garden walks, or on arbors, the sweet perfume of blooming Roses is a source of constant delight to all who grow them.

The varieties listed below are offered with a view of supplying a collection which combines as varied a range of color as can be brought together in a limited number of sorts. Many kinds have been omitted, not because they are of no value, but that the sorts listed are superior in size, hardiness, vigor, productiveness, or some other characteristic necessary to make a good garden rose.

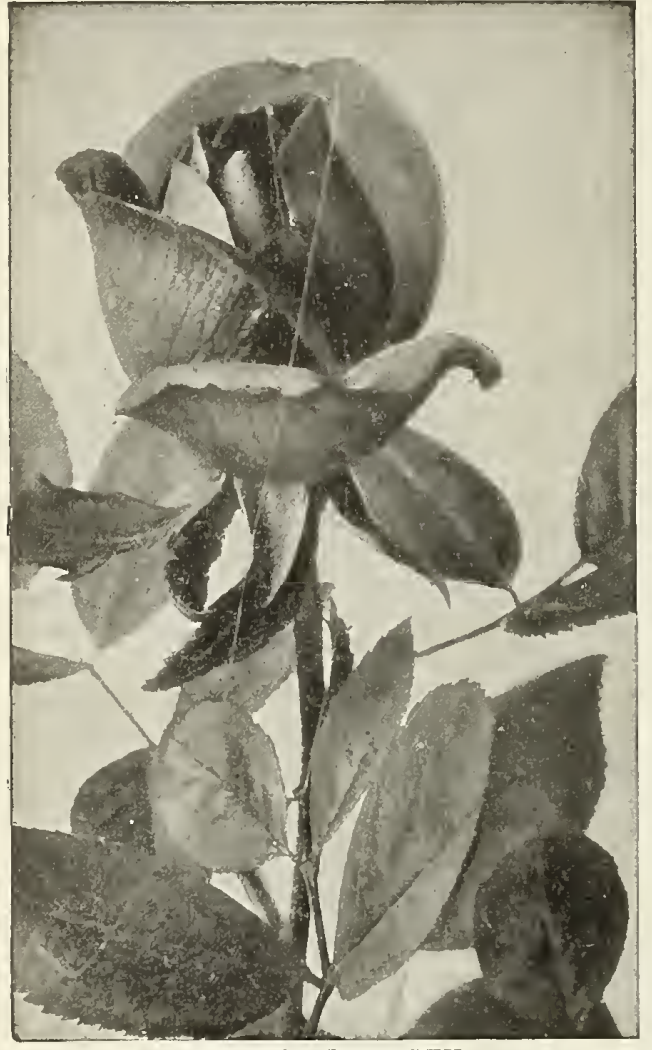

AMERICAN BEA UTY

The plants we offer are extra heavy 2-year-old stock, which will under ordinary conditions give a full crop of flowers the first season.

Planting.-Roses planted in the spring should be set out early, in a rich clay-loam, and firmly pressed in with the foot.

Pruning.-When setting out hardy Roses, cut them back $\frac{1}{2}$ to $\frac{\pi}{3}$ and remove all feeble growth. The result will be strong plants and large flowers.

American Beauty.- The flowers are very large, very double and of beautiful form; color rich deep rose. The fragrance is delightful; a continuous bloomer.

Baroness Rothschild.-A magnificsnt rose; color is a rich satiny pink.

Frau Carl Druschki.-The grandest white hardy rose introduced for years. Produces very freely flowers of exceptionally large size, very full and double and of a pure snow white. It forms a beautiful long shaped bud.

General Jacquimenot.-Rich velvety crimson, changing to scarlet crimson.

Gruss an Teplitz.-The reddest of all red roses; it is of the richest scarlet imaginable, shading to vel vety crimson as the flowers mature; very fragrant, a most profuse bloomer; the foliage is extremely beautiful, all the younger growth being of bronzy plum color.

KILLARY. New Hardy Everblooming Irish Rose. A beautiful new Irish Rose, certain to become a general favorite. It is perfectly hardy, a strong and robust grower, and as free flowering as any rose we know. In color it is a brilliant, satiny, soft pink; the blooms are large, the buds long and pointed. Just as handsome in the full-blown flower as in the bud form.

\section{Each $35 \mathrm{c}$, dozen $\$ 3.50$}

Mad. Plantier.-White flowers in great abundance.

Magna Charta.-Bright pink, suffused with carmine; a beautiful rose; strong, vigorous grower.

Mrs. John Laing.-Soft pink; exceedingly fragrant; commences flowering early and continues late. Paul Neyron.-Deep, shining pink. Good, strong grower, almost thornless.

Persian Yellow.-Perfectly hardy, semi-double, golden yellow.

Soleil d'Or.-Beautiful clear green, dense foliage. Large, full, globular flowers, fragrant; buds conical; color varying from gold and orange-yellow to reddish gold, and shaded with nasturtium red. Ulrich Brunner.-Brilliant cherry red, a very effective color. PRICES:-Extra heavy 2-year-old plants, except where noted, Each 25c, dozen $\$ 2.50$

\section{New Everblooming Rose “BABY RAMBLER”}

A dwarf form of the widely known and popular climbing rose Crimson Rambler. The flowers are borne in clusters like those of the Crimson Rambler and are of the same charming brilliant red color. The best red pot or bedding rose in the world. Perfectly hardy, in bloom all the time. Each 40c, doz. $\$ 4.00$

\section{MOSS ROSES}

A class of Roses much admired. The beauty consists in the delicate mossy covering which surrounds the bud.

Blanche Moreau.-Pure white. Pink.- Ea. 25c, doz. $\$ 2.50$

\section{RUGOSA ROSES}

Handsome foliage and clusters of beautiful single flowers followed by brilliant red seed pods. Splendid for hedges.
R. Alba.-White.
R.Rubra.-Red
Ea. 25c, doz. $\$ 2.50$

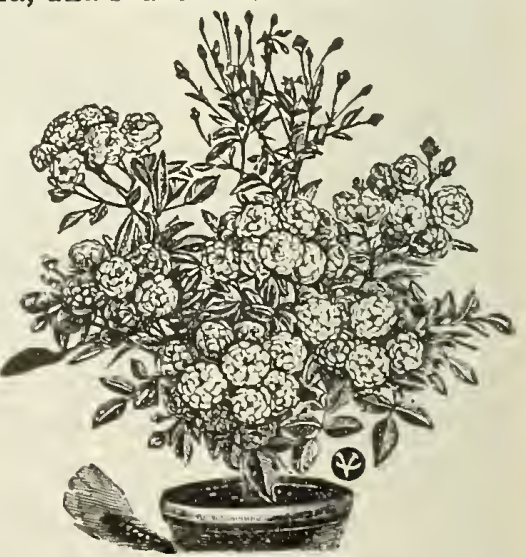

BABY RAMBLER. 


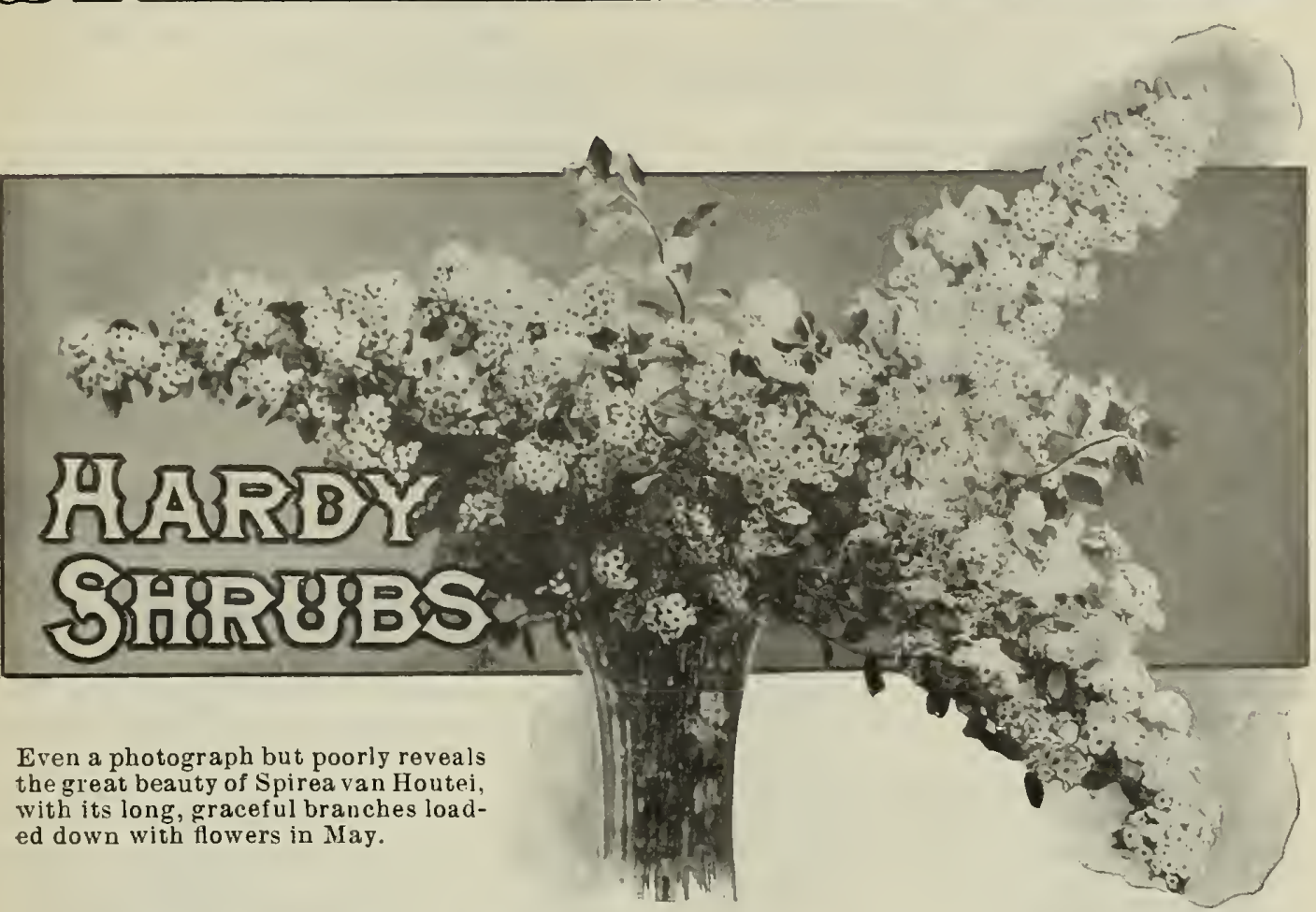

Shrubbery has become an almost indispensable part in the planting of home grounds, and justly so, for there is nothing that will add so to the value of a place or to its beauty as a few well selected and judiciously planted shrubs. There are locations which call for the planting of individual specimen shrubs, or they may be used in masses for border and screen work, in forming groups and beds. The brilliant fruits of some varieties and the brightly colored bark of others help to relieve the monotony of winter.

We cater to the plant buyer who appreciates the value of quality. It requires little skill, less ground and but a layman's attention to grow the ordinary run of stock, and if you are seeking to buy nursery stock at the lowest possible price you must not expect to get the best quality. We prefer to handle stock grown for "quality" and allow "price" to arrange itself; not an exhorbitant price but only a fair return for what we sell you.

We do not handle Dutch nursery stock. All our trees and shrubs are American-grown. "Dutch stuff" is really forced into an unnatural growth, because the water is only 18 inches below the surface in some of those Dutch nurseries. That eminent authority, Wilhelm Miller, editor of the GARDEN MAGAZINE, in an article in COUNTRY LIFE IN AMERICA says:- "One of the excuses we all make is that 'the plants die,' and we blame this on climate. The chief reason why plants die is that we buy 'Dutch stuff', simply because it is 'chea pest'. There is no fault of character here. Most Americans do not know they are buying Dutch trees, shrubs and evergreens. They mean to buy hardy material, and are heart-brokeu when it dies after a winter or two. The Dutch plants always look best, and how shall an innocent investor be on his guard? Apparently there is no way. He must try and lose before he is willing to pay a fair price for American-grown material."

By insisting on getting American-grown stock, and buying only from such houses that will not handle the inferior Holland-grown, you avoid the chance of much aggravating loss.

Prices are based on well-shaped, bushy, vigorous plants, with heavy root growth, such as produce immediate effect. They can be shipped only by express or freight, being too large and heavy to be sent by mail. Write for prices in larger quantities.

\section{HELPFUL INFORMATION} SHRUBS WHICH BEAR SHOWY FRUIT

The value of berry-bearing shrubs and their high ornamental value especially in fall and winter, is gradually being recognized by discriminating planters.

Barberry.-Scarlet fruit.

Cornus. (Dogwood).-Dark blue-black berries.

Hawthorn.-Immense brilliant red haws.

\section{IN SELECTING SHRUBS.}

Lonicera. (Honeysuckle).-Red and yellow fruit Rosa Rugosa.-Bright scarlet hips.

Symphoricarpus Racemosus. (Snowberry).White berries all winter.

Symphoricarpus Vulgaris.-Red berries.

Viburnum Lantana.-Fruit changes frnm pale green to carmine, and finally becomes black.

Viburnum Opulus. (Cranberry Bush). -Red fruit 


\section{SHRUBS WITH COLORED BARK}

These are especially valuable and conspicuous in the winter landscape, lending a touch of color extremely welcome.

Cornus Alba. (Dogwood).-Bright red.

Kerria Japonica.-Green.

Golden Willow.-Bright yellow.

SHRUBS WITH BRIGHTLY COLORED FOLIAGE

Barberry Thunbergii.-Bright red after frost.

Barberry Purpurea.-Purple.

Prunus Pissardi.-Purple.

Sambucus Aurea. (Golden Elder).-Yellow.

SHRUBS SUITABLE FOR SHADY PLACES

Barberries in variety.

Cornus in variety.

Deutzia.-Gracilis and Lemoinei.

Forsy thia.

Symphoricarpus. (Snowberry).

Viburnum in variety.
SHRUBS SUITABLE FOR HEDGES

Barberry Thunbergii.

Barberry Vulgaris.

Haw thorn.

Hydrangea Paniculata.

Japan Quince.

Rosa Rugosa.

Spireas in variety.

SHRUBS BLOOMING BEFORE LEAVES APPEAR

Cornus Florida. Cydonia Japonica.

Forsythia. Prunus Triloba.

SIX SHRUBS THAT GIVE BLOOMS FROM APRIL TO OCTOBER

April-Forsythia.

May-Lilacs.

June-Spireas.

July-Deutzias.

August-Althaea.

September to October-Hydrangea.

FLOWERING SHRUBS NAMED IN THE ORDER IN WHICH THEY BLOOM

Forsythia. April

Forsythia.

Japan Quince.

Prunus Pissardi and Triloba.

Flowering Almond.

Spirea, in variety.

Lilacs, in variety.

Viburnum Lantana.

Bush Honeysuckle.

Wistaria.

\section{FLOWERING ALMOND}

\section{Double White and Pink}

A bea $\mathrm{t}$ if ul tree, covered in May and June with double rose-like flowers. Strong bushes, $3 \mathrm{ft}$. Each $40 \mathrm{c}, 3$ for $\$ 1.00$, dozen $\$ 3.50$

\section{ALTHAEA, OR ROSE OF SHARON}

Bloom late in August and September, at a time when we have so few shrubs in flower. Flowers large and brightly colored, much like Hibiscus or Hollyhock in form. Double white, violet, pink, red. 3-year-old bushes, each 35c, doz. 3.50

\section{BERBERIS .. BARBERRY}

BERBERIS THUNBERGII, Japanese Barberry

One of the most beautiful shrubs in cultivation, either for hedging or general purposes. It is of neat, compact growth and never need be touched with the shears. The foliage is beautiful at all times, and in the fail turns to a most brilliant crimson color, but its most attractive feature is its fruit. The plants are literally covered with bright scarlet berries all fall and winter. It is fine for the edge of a terrace and along roads and walks, or for grouping on the lawn. We offer fine bushy stock, 2 feet high.

Each $35 \mathrm{c}$, dozen $\$ 3.50,100 \$ 22.00$

Purpurea.-Purple-Leaved Barberry. Very striking; fine as a single specimen or for hedges.

2 to 3 feet, bushy, each 35 c, dozen $\$ 3.50$ Vulgaris. - Light green leaves, and later bright red berries.

Each $35 \mathrm{c}$, dozen $\$ 3.50$.

CALYCANTHUS (Sweet Shrub)-The Calycanthus is one of the most desirable shrubs. The wood is fragrant. Flowers are of a rare chocolate color, having an exquisite pine-apple fragrance.

Each $35 \mathrm{c}$, dozen $\$ 350$
Elder.

Deutzia, Pride of Rochester. July

Weigelia, in variety.

Spirea Billardi.

Spirea Anthony Waterer. August

Althæa, in variety. September

Hydrangea Paniculata Gr. Clematis Paniculata.

\section{CHIONANTHUS VIRGINICA White Fringe}

Bushy shrub, sometimes growing into a tree. Literally covered in May and June with loose, drooping panicles of graceful, delicate white flowers, followed by showy purple fruit. The foliage changes to yellow and bronze tints in the fall. Bushy plants, $2 \frac{1}{2}$ feet high, each $50 \mathrm{c}$, doz. $\$ 5.00$

\section{CORNUS, OR DOGWOOD}

Sanguinea.-Clusters of white flowers, stem and branches turning blood red in winter.

3 to 4 feet, each $35 \mathrm{c}$, dozen $\$ 3.50$

CRATAEGUS, OR HAWTHORN

Coccinea.-Red flowering. Among the most beautiful of our flowering trees; dense, low grower, occupying comparatively little space.

2 to 3 feet, each $35 \mathrm{c}$, dozen $\$ 3.50$

FLOWERING CURRANT (Ribes Aureum)

Yellow flowering or Missouri Currant: 3 feet Each $35 \mathrm{c}$, dozen $\$ 3.50$

\section{CYDONIA JAPONICA (Japan Quince)}

The large, brilliant, scarlet-crimson flowers are among the first blossoms in spring, and they appear in great profusion covering every branch. Special attention is invited to this plant for ornamental hedges. 2 to $3 \mathrm{ft}$, ea. $35 \mathrm{c}$, doz. $\$ 3.50$

CYTISUS LABURNUM (Golden Chain)

Extremely bright with graceful racemes of wistaria-like golden yellow flowers. Each $35 \mathrm{c}$

Clethra AlNifolia (Sweet Pepper Bush) - A grand shrub, covered with spikes of clear, white, fragrant flowers in August. $1 \frac{1}{2}$ to 2 feet. Bushy, 35c; doz. $\$ 3.50$. 


\section{HARDY ORNAMENTAL SHRUBS CONTINUED}

\section{DEUTZIA}

Their hardihood, fine habit, luxuriant foliage and profusion of attractive flowers from June to August, place them among the most popular of flowering shrubs.

Gracllis.-Of dwarf habit, with slender branches of pure white flowers. Each $25 \mathrm{c}$, dozen $\$ 2.50$ Lemoinei.-Entire plant covered with erect panicles of snow-white flowers. Each 35c, dozen 3.50 Pride of Rochester.-Double white, under side of petals slightly tinted rose. Each $35 \mathrm{c}$, doz. $\$ 3.50$

\section{FORSYTHIA}

As soon as winter has departed, the bright golden yellow, star-like flowers appear along the naked branches in a wealth of bloom that is especially cheerful so early in the season.

Fortunei.-Erect, upright growth. Each 35c, Viridissima.-Medium height. $\}$ dozen. $\$ 3.50$

\section{BUSH HONEYSUCKLE}

Tartarian Red.-Small, fragrant, pink, crimson or blush flowers, followed by red or orange berries. Tartarian White.- Each $35 \mathrm{c}$, dozen $\$ 3.50$

\section{HYDRANGEA PANICULATA GRANDIFLORA}

This is one of the finest hardy shrubs in cultivation. It flowers abundantly, bearing immense panicles of bloom, white at first, turning gradually to rose color, commencing in August, when very few shrubs are in bloom. An annual shortening of the branches tends to increase the growth of new wood, and it is upon this that the great heads appear.

Fine bushy plants, each $35 \mathrm{c}$, dozen $\$ 3.50,100 \$ 20.00 \quad$ Tree Shaped, each 50c, dozen $\$ 5.00$

\section{HYDRANGEA ARBORESCENS}

This magnificent, perfectly hardy American shrub is the finest addition to this class of plants in many a year. The snow-white blooms are of large size, the foliage finely finished. One of the most valuable characteristics is its coming into bloom just after the passing of the early spring shrubs, flowering from Jun to August. Does particularly well in shade.

Each $50 \mathrm{c}$, dozen $\$ 5.00$

\section{LILACS}

Common, Purple and White.- Ea. 25c, doz. $\$ 2.50$ Charies X.-Large reddish-purple. Each $50 \mathrm{c}$ Japonica.-Tree Lilac. Creamy-white. Each 50c Leon Simon.-Bluish crimson; double. Each 50c Madame Casimir Perier.-Creamy-white, double; superb. Each $50 \mathrm{c}$ Michael Buchner.-Double, pale lilac. Each 50c Persian, Purple and White.-Each $40 \mathrm{c}$, dozen $\$ 4.00$ Rothomagensis.-Large reddish-purple. Each $40 \mathrm{c}$ Rubra de Marley.-Single rosy-purple. Each 35c Souvenir de Ludwig Spaeth.-Rich dark purple of oxtraordinary size; single.
PHILADELPHUS (Mock Orange)

Coronarius.-Very sweet and one of the earliest. Coronar. fl. pl.-Double. Aurea.-Golden leaved. Grandiflora.-Forms a large, spreading bush.

Each $35 \mathrm{c}$, dozen $\$ 3.50$

\section{PRUNUS}

Pissardi.-Purple-leaved plum. Each $40 \mathrm{c}$ Triloba.-Delicate pink double flowers. Ea. $40 \mathrm{c}$

\section{RHUS (Sumach)}

Glabra Laciniata.-Cut leaved; ight red in fall. Typhina Laciniata.-Fern-leaved Staghorn Sumac. Each $35 c$, dozen $\$ 3.50$

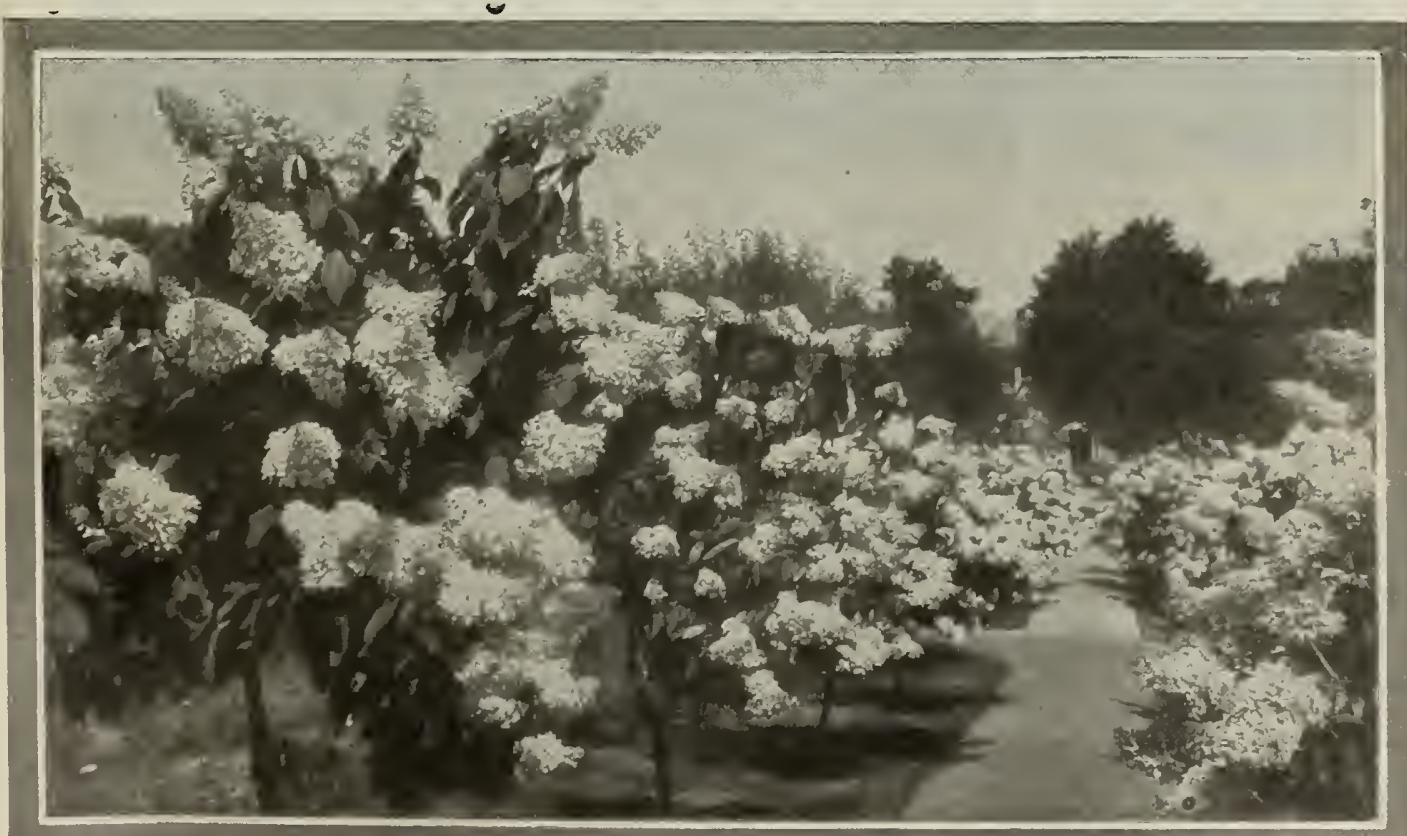




\section{HARDY ORNAMENTAL SHRUBS CONTINUED.}

\section{SAMBUCUS (Elder)}

Aurea.-Golden Elder. Beautiful golden yellow foliage, grand as a single specimen or for planting in masses. 2 to 3 feet, each $35 \mathrm{c}$, dozen $\$ 3.50$ Laciniata.-Cut Leaved Elder. Ea. 25c, doz. 2.50

\section{SNOWBERRIES}

For massing these shrubs are unsurpassed. They spread so rapidly from underground shoots that a few plants will produce a thicket in a short time. Far into winter the berries are as bright as before the cold came.

Racemosus.-Large white berries.

Vulgaris.-Red-fruited. Each 35 c, dozen $\$ 3.50$

\section{SPIREA}

Graceful shrubs everyone should plant; they are of easiest culture.

Perpetual-blooming Red Spirea, Anthony Waterer -A fine, hardy, perpetual-blooming shrub, particularly desirable for the lawn. Nice, round bushes, 3 feet high and wide; rosy red flowers in large, round clusters all over the bush.

Fine, bushy, 2 to $2 \frac{1}{2}$ feet, each $35 \mathrm{c}$, dozen $\$ 3.50$

S. Billardi.-Erect branches crowned with narrow dense spikes of bright pink flowers. June to September.

2 to 3 feet, each, 35 c dozen $\$ 3.50$

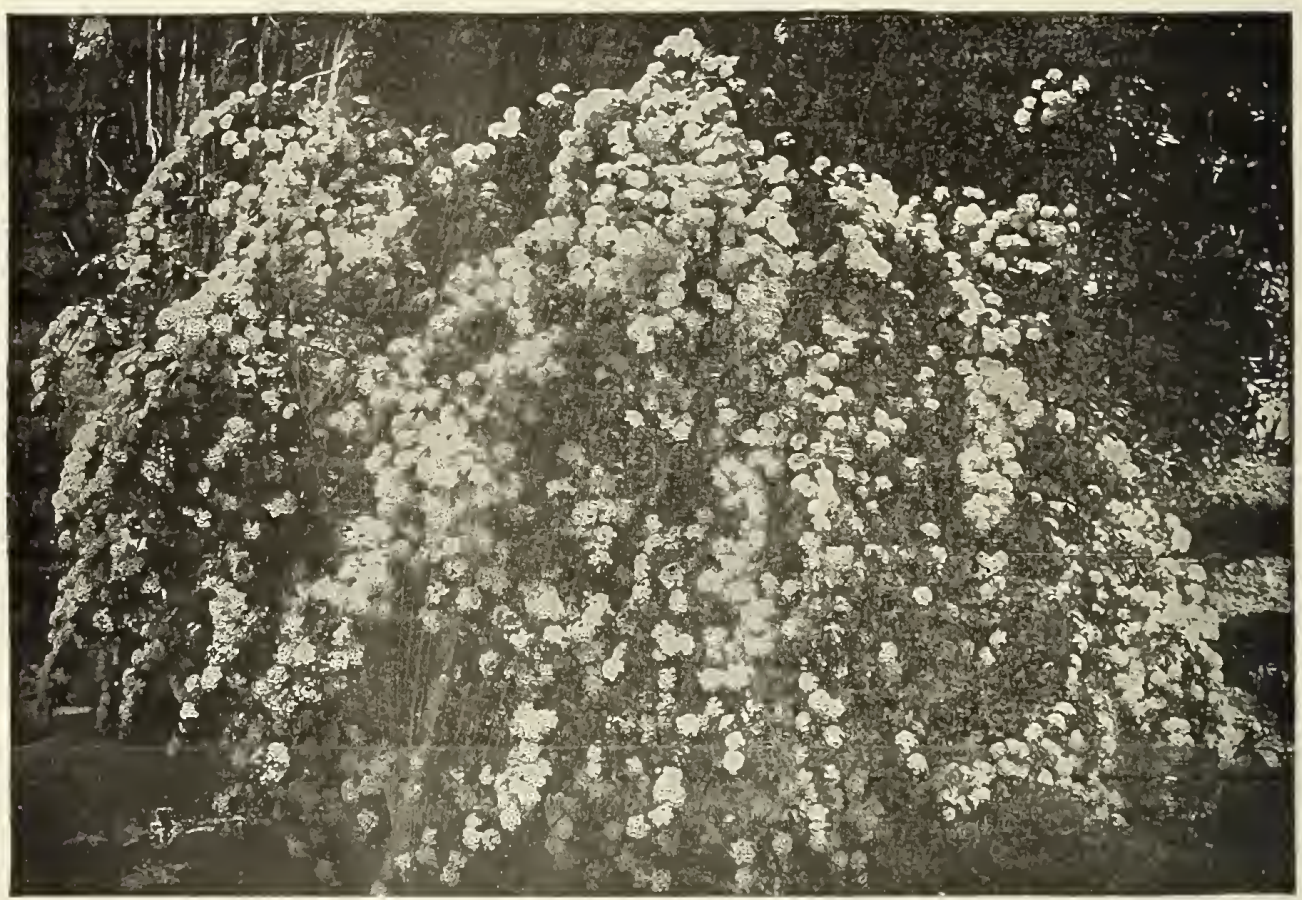

SPIREA VAN HOUTTEI (BRLDAL WREATH)

SPIREA VAN HOUTTEI.-(Bridal Wreath.) If you have need for but one spring-flowering shrub, plant Spirea Van Houttei. It is the grandest of all the white Spireas. A beautiful ornament for the lawn at any season, but when in flower it is a complete fountain of white bloom, the foliage hardly showing. Clusters of 20 to $30 \mathrm{flat}$ white florets make up the raceme, and are set close along the drooping stems.

2 to 3 feet, each 25 c, dozen $\$ 2.503$ to 4 feet, each 35 c, dozen $\$ 3.50$

Extra heavy specimen plants, 4 to 5 feet high, widely branched, each 75 c, dozen $\$ 7.50$

\section{VIBURNUMS.}

In this group are included the Snowballs, which give in spring the same showy effect produced by Hydrangeas in the fall.

Lantana.-May and June. White flower cluster's, succeeded by red fruits that later turn to black.

2 to 3 feet, each $40 \mathrm{c}$, dozen $\$ 4.00$

Opulus.-Cranberry Bush. Single white flowers borne in flat clusters. Highly valued for the brilliant red berries that cling to the branches all winter, unmolested by birds. Ea. 35c, dozen 3.50 Sterile.-The old-fashioned Snowball that grows almost anywhere and flowers so abundantly.

3 to 4 feet, each $35 \mathrm{c}$, dozen $\$ 3.50$
Viburnum Plicatum.-(Japan Snowball.) Large snow-white balls of flowers. Ea. 50c, doz. $\$ 5.00$

\section{WEIGELIAS}

Beautiful shrubs that bloom in June and July. Superb, large, trumpet-shaped flowers, produced very lavishly.

Candida.-Flowers pure white.

Eva Rathke.-Brilliant crimson; a beautiful, distinct, clear shade.

Rosea.-Rose colored; the most popular.

Variegata.-Leaves margined creamy white; flowers pink.

2 to 3 feet, each 35 c, dozen $\$ 3.50$ Extra large, each 50 c, dozen $\$ 5.00$ 


\section{DECIDUOUS ORNAMENTAL, \& FRUIT TREES}

All the trees that we offer have been grown with care, to make them straight, stocky, well headed and supplied with fibrous roots. Prices will be quoted on any desired size.

\section{ACER - THE MAPLES}

The Maples are perhaps more largely planted than any other family of trees. They are highly ornamental, regular in outline, beautiful in foliage and adapted to all soils.

Norway Maple.-Large, handsome tree of spreading, rounded form, with broad, deep green, shining foliage.

8 to 10 feet, each $\$ 1.25$

Purple Leaved Norway Maple.-(Schwendler's.) The red and purple tints contrast beautifully with the delicate green of spring. In summer and fall the color is not so pronounced. 6 to $8 \mathrm{ft}$., $\$ 1.50$

\section{AESCULUS - HORSE CHESTNUT}

White Flowering.-Magnificent spikes of white flowers. As a lawn tree or for the street it has no superior.

5 to 6 feet, each $75 \mathrm{c}$

\section{BETULA - THE BIRCHES}

Elegant, graceful form, with slender branches and light and airy foliage.

European White.-With slender branches and silvery bark. After a few years growth, assumes a graceful, weeping habit, adding greatly to its beauty. 6 to 8 feet, ea. 75 c, 8 to 10 feet, ea. $\$ 1.25$ Cut.Leaved Weeping.-One of the most elegant of all weeping or pendulous trees. Its tall, slender, yet vigorous growth, graceful, drooping habit, silvery white bark and delicately cut foliage present a combination of attractive characteristics rarely met with in a single tree.

4 to 5 feet, each $75 \mathrm{c}, 6$ to 8 feet, each $\$ 1.00$

\section{CATALPA}

Speclosa.-Large, heart-shaped, downy leaves, and compound panicles of white flowers. Very ornamental and useful.

8 to 10 feet, each $75 \mathrm{c}$

\section{FAGUS - THE BEECHES}

European Beech.-A beautiful tree, attaining a height of 60 feet.

4 to 6 feet, each $75 \mathrm{c}$

Purple Leaved Beech.-The foliage in spring is deep purple, later changing to erimson, and in fall to a dull purplish-green.

4 to 6 feet, each $\$ 1.25$

\section{TEAS' WEEPING MULBERRY}

The most beautiful of weeping trees. The slender branches grow downward parallel with the stem, forming an umbrella-like shape. All who have seen it agree that in light, airy gracefulness, delicacy of form and motion, it is without a rival. It has beautiful foliage, and is hardy and enduring.

2 year head, each $\$ 1.25$

\section{POPULUS - POPLAR}

Carolina Poplar.-For quickly producing street shade there is probably no tree which equals the Carolina Poplar. It is broadly pyramidal in form, very robust in growth, with large, glossy, deep green leaves. It stands the smoke and dust of eity streets better than any other shade tree.

8 to 10 feet, each $75 \mathrm{c}$

PYRUS - FLOWERING CRAB APPLE

Bechtel's Double Flowering.-One of the $\mathrm{mos} t$ beautiful flowering trees. Tree of medium size, covered in early spring with large, beautiful, aouble, fragrant flowers of a delicate pink color 3 to 4 feet, each $65 \mathrm{c}$

\section{TILIA - LINDEN}

Amcrlcan.-(Basswood.) A rapid growing, bea utiful tree, with very large leaves and fragrant Howers.

6 to 8 feet, each $75 \mathrm{c}$

\section{ULMUS - THE ELMS}

A merican.-A noble native tree of large size, wide-spreading head, and graceful drooping branches. The grandest park and street tree. 8 to 10 feet, each $\$ 1.002$ to $2 \frac{1}{2}$ inch trunk, $\$ 2.00$ Camperdown.-Its vigorous, irregular branches, which have a uniform weeping habit, overlap so regularly that a compact, roof-like head is formed. Leaves are large, glossy, dark green. A strong vigorous grower, The finest Weeping Elm and one of the best weeping trees.

\section{2 year head, each $\$ 1.25$}

\section{A SELECTION OF THE BEST SORTS OF FRUIT TREES}

\section{ARRANGED IN ORDER OF RIPENING}

\section{APPLES}

Duchess.-Good size, juicy, yellow streaked and shaded red. Should be in every orchard.

Wealthy.-A large, smooth apple of excellent quality, and very beautiful,-almost entirely overspread with brilliant dark red; very hardy.

Fameuse or Snow.-Medium size, deep crimson, flesh snowy white, tender, melting and delicious. Northwestern Greening.-Hardy, greenish-yellow; of good size, extra long keeper.

Pewaukee.-Medium to large; very hardy; bright yellow striped and splashed with dark red.

\section{5 to 7 feet, each 50 c, dozen $\$ 5.00$}

\section{CRAB APPLES}

Whitney.-Very large; green, striped and splashed with bright red.

Florence. - The best of all crabs; striped and mottled crimson and yellow.

Martha.-Beautiful bright yellow, shaded red.

$$
5 \text { to } 7 \text { feet, each } 50 \text { c, dozen } \$ 5.00
$$

\section{CHERRIES}

Dyehouse,-Larger, better, earlier than Richmond Montmorency.-Bea utiful, large, red, acid cherry, superior to Richmond in tree and fruit, and the best of the sour cherries.

English Morello.-Medium size, dark red, nearly black; juicy, acid.

5 to 7 feet, each $75 \mathrm{c}$, dozen $\$ 7.50$

\section{PEARS}

Bartlett.-Large, buttery and melting, with a rich musky flavor; golden yellow.

Flemish Beauty.-Pale yellow with reddish-brown cheek; sugary, rich, and juicy.

Kieffer.-Golden yellow, often tinted red on sunexposed side; very vigorous and a great yielder.

5 to 7 feet, each $50 \mathrm{c}$, dozen $\$ 5.00$

\section{PLUMS}

Burbank.-Large, round, cherry red.

Wild Goose.-Bright red, very sweet and juicy.

Lombard.--Medium size, fine quality, violet red.

Green Gage.-Small, but good; greenish-yellow.

Shipper's Pride.-Large dark purple.

5 to 6 feet, each $50 \mathrm{c}$, dozen $\$ 5.00$ 


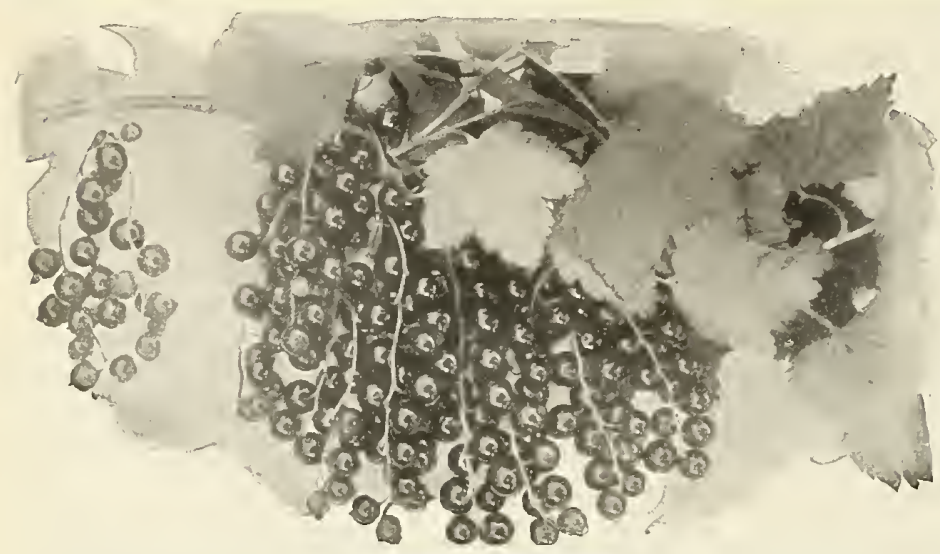

WILDER CURRANT

\section{BLACKBERRIES}

Mersereau.-A large jet black of fine quality.

Rathbun.-Very large, good quality, jet black.

Ea. 10 c, doz. $\$ 1.00,100 \$ 7.50$

\section{CURRANTS}

Black Naples.--Large and fine Fay's Prolific.-Popular red; fruit large and handsome.

Perfection.-Beautiful bright red, rich and mild, with few seeds. A great bearer.

Red Cross.-Deep red, sweet, and of high quality; large size long clusters.

White Grape.--Very large yellowish white of excellent quality.

Wilder.-Large, brilliant red, of fine quality. Great yielder. The fruit hangs on the bushes in fine condition after ripening.

TWO YEAR

Each $15 c$, dozen $\$ 1.50$

THREE YEAR

Each 20 c, dozen $\$ 2.00$

\section{DEWBERRY}

Lucretia.-A trailing variety of the Blackberry, ripening between the Raspberry and the Blackberry.

Each $10 \mathrm{c}$, dozen $\$ 1.00$

\section{ELDERBERRY}

Has jet black berries, borne in great clusters. Delicious for pies or canning.

Each $25 \mathrm{c}$, dozen $\$ 2.50$

\section{BUFFALO BERRY}

The berries, sometimes red and sometimes yellow, are very good for jelly.

Each $35 \mathrm{c}$, dozen $\$ 3.50$

\section{SMALL \\ FRUITS}

Until you have entered on the culture of berries and other small fruits, you have no idea of the joy and profit these bring to the amateur gardener. They are as easily grown as regetables, and on city and suburban lots should always be given preference over tree fruits.

We have prepared a booklet entitled "Small F'ruits for Home Garden and Orchard", containing direction for planting, pruning, cultivating and spraying all kinds of small fruits. It is free.

\section{GRAPES}

Brighton.-Bunches large; dark red.

Concord.-Blue-black; the most popular grape in America.

Diamond.-Greenish white, juicy with few seeds.

Niagara.-Bunch and berries are large; greenish white.

Worden.-A black grape of the Corcord type; larger and earlier. Each 20c, dozen $\$ 2.00,100 \$ 12.00$

\section{GOOSEBERRIES}

Cha utauqua.-Yellowish-white; sweet, rich, and of good quality. A great yielder.

Downing.-Large, handsome, of splendid quality; pale green. A vigorous grower

Houghton.-Small to medium, sweet, tender, thin skinned, red variety. Great bearer.

Pearl.-Light yellowish-green of high quality. It is a little larger than Downing.

TWO YEAR

Each 20 c, dozen $\$ 2.00$ THREE YEAR

Each 25c, dozen \$2.50

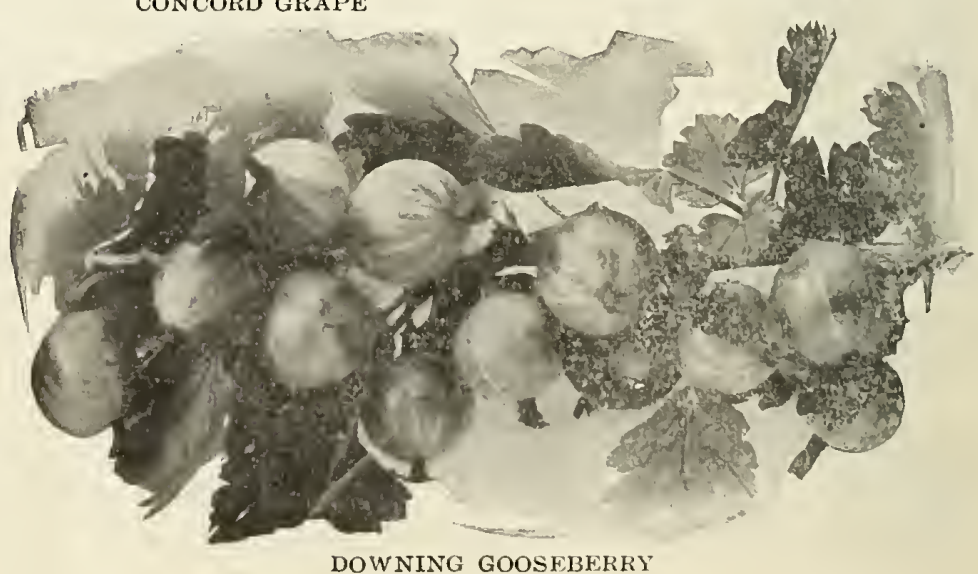




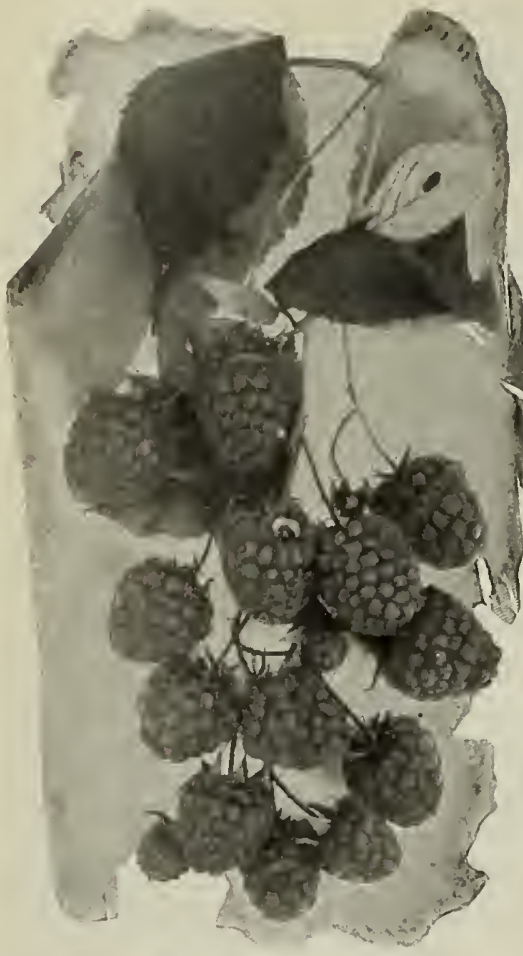

COTHBERT RASPBERRY

\section{SMALL FRUITS CONTINUED}

\section{RASPBERRIES}

Columblan.-Deep purplish red; sweet and highly fiavored. Cumberland.-The best black; very large, firm and prolific Cuthbert.-Deep rich crimson; very large, conical; hardy and prolific, and so firm they stand shipping long distances; flavor sweet and rich.

Marboro.-Light crimson; of large size, good quality, early, hardy, vigorous and firm.

Each 7c, dozen 75c, $100 \$ 5.00$

The Herbert Raspberry.-(New.) A raspberry of splendid quality, originated in Canada. A very strong grower, hardy and very productive. Fruit large to very large, conical, bright to rather deep red, moderately firm, juicy, and of good flavor. Season begins a few days before Cuthbert.

Each $15 \mathrm{c}$, dozen $\$ 1.25,100 \$ 8.00$

\section{STRAWBERRIES}

In the city or on the country place, the family garden is not complete without strawber. ries. The chief considerations for a home berry are flavor and beauty of form and color. The following are excellent varieties which meet all the requirements of a first-class home berry,

Brandywine.-Large, roundish, conical berry of fine, rich flavor. Color deep blood red to the center. Combines productiveness with size and beauty. Moderately firm; a good canner; season medium to late.

Uncle Jim.--Very large and prolific midseason variety. Dark crimson and showy.

Dozen 20c, $100 \$ 1.25,1000 \$ 7.50$

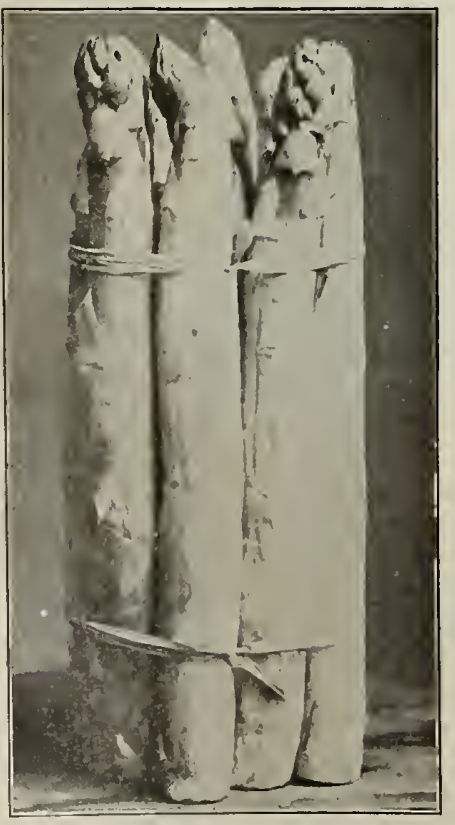

ASPARAGUS, COL. MAM. WHITE
VEGETABLE ROOTS \& PLANTS ASPARAGUS

Columbian Mammoth White.Shoots are white, very large, numerous and of fine quality. TWO YEAR

Dozen 15c, $100 \$ 1.00$

\section{CHIVES}

Each 5c, dozen 50c HORSE RADISH SETS

Dozen 20c, $100 \$ 1.00$ LAVENDER.-Is used for seasoning and perfumes.

Each 15c, dozen $\$ 1.50$

PEPPERMINT. / Ea. 10c SPIRMINT.- $\}$ doz. 1.00

\section{RHUBARB}

Victoria.-Leaf stalk very tall and large. Pulp quite acid. Very productive and profitable.

Each 10c and 15c, according to size.

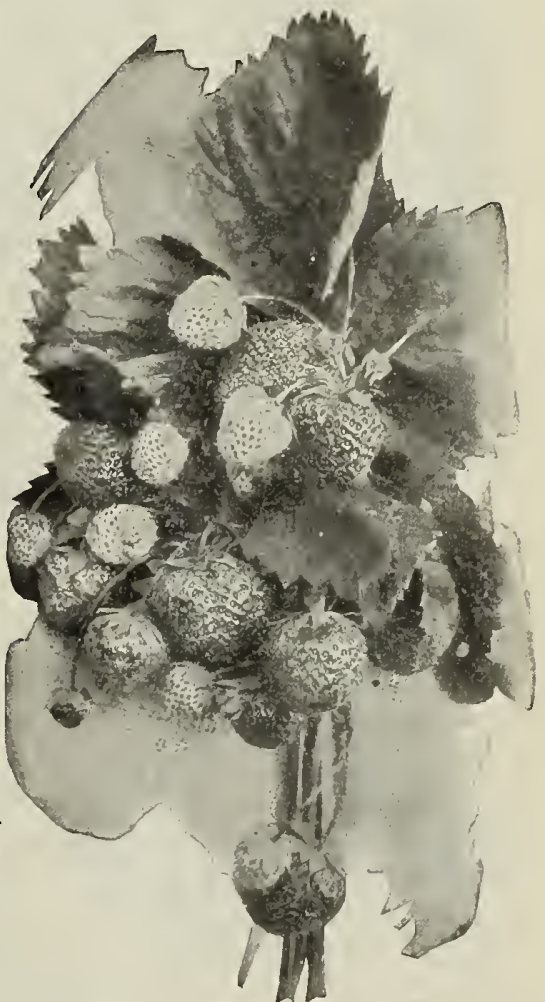

BRA NDYWINE STRA WBERRY

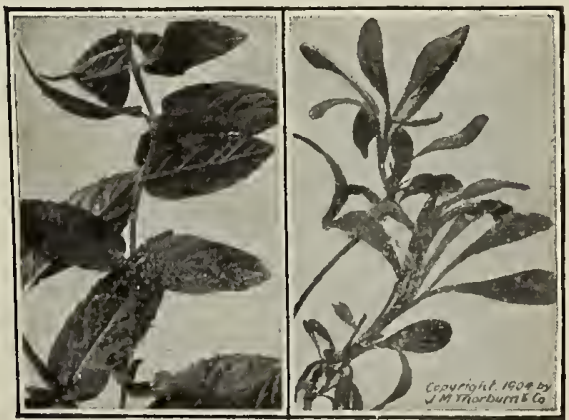



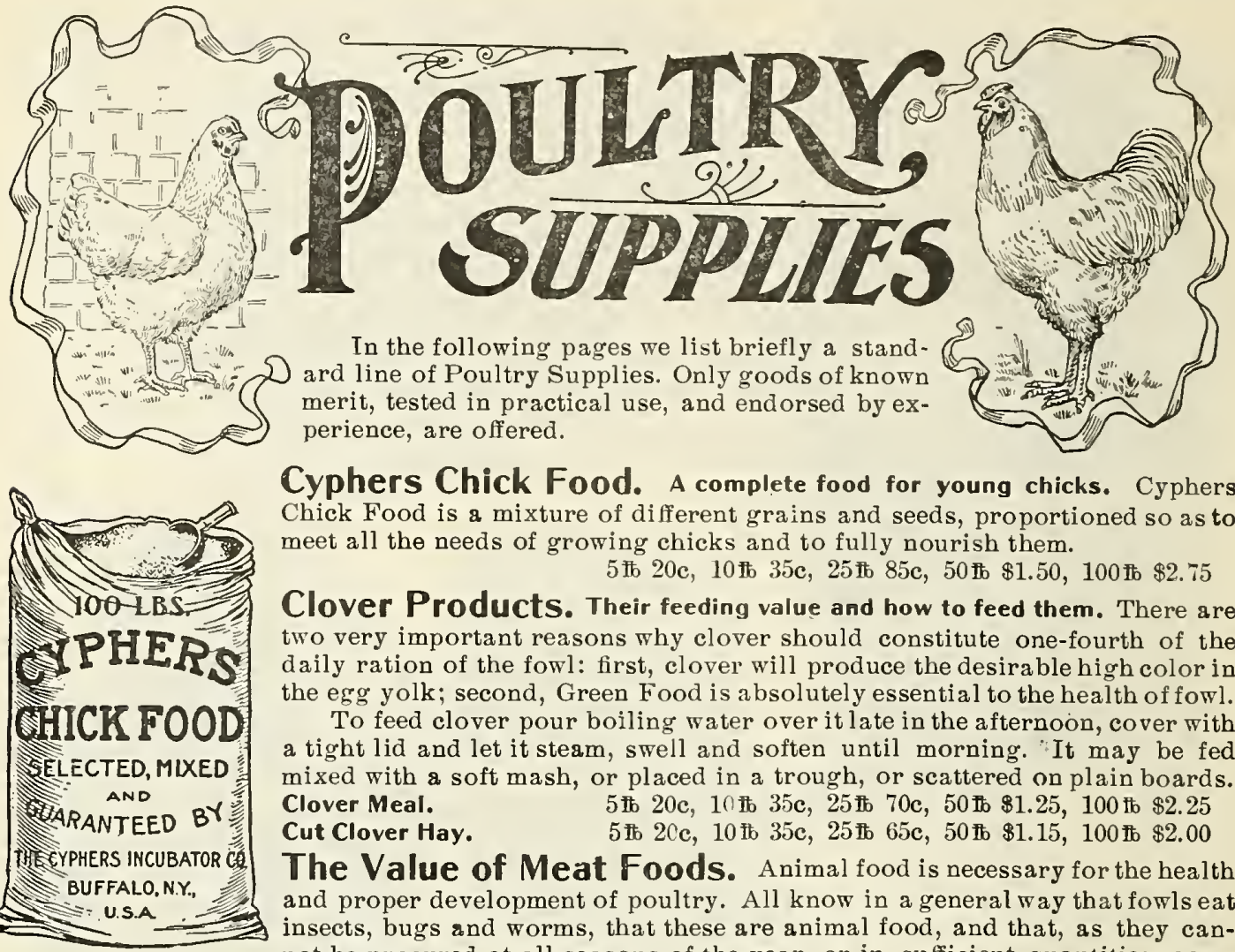

Cyphers Chick Food. A complete food for young chicks. Cyphers Chick Food is a mixture of different grains and seeds, proportioned so as to meet all the needs of growing chicks and to fully nourish them.

$5 \mathrm{fb} 20 \mathrm{c}, 10 \mathrm{fb} 35 \mathrm{c}, 25 \mathrm{fb} 85 \mathrm{c}, 50$ 开 $\$ 1.50,100$ 古 $\$ 2.75$

Clover Products. Their feeding value and how to feed them. There are two very important reasons why clover should constitute one-fourth of the daily ration of the fowl: first, clover will produce the desirable high color in the egg yolk; second, Green Food is absolutely essential to the health of fowl.

To feed clover pour boiling water over it late in the afternoon, cover with a tight lid and let it steam, swell and soften until morning. "It may be fed mixed with a soft mash, or placed in a trough, or scattered on plain boards. Clover Meal. $\quad 5$ tb 20c, 10 tb $35 \mathrm{c}, 25$ th $70 \mathrm{c}, 50 \mathrm{tb} \$ 1.25,100 \mathrm{tb} \$ 2.25$ Cut Clover Hay. $\quad 5 \mathrm{tb} 20 \mathrm{c}, 10 \mathrm{fb} 35 \mathrm{c}, 25 \mathrm{fb} 65 \mathrm{c}, 50 \mathrm{mb} \$ 1.15,100 \mathrm{fb} \$ 2.00$

The Value of Meat Foods. Animal food is necessary for the health and proper development of poultry. All know in a general way that fowls eat insects, bugs and worms, that these are animal food, and that, as they cannot be procured at all seasons of the year, or in sufficient quantities, some form of meat food must be supplied.

Beef Scrap.- An especially valuable meat food for poultry, and gives very satisfactory results when fed dry from a food hopper.

$5 \mathrm{fb} 25 \mathrm{c}, 10 \mathrm{tb} 45 \mathrm{c}, 25 \mathrm{fb} 90 \mathrm{c}, 50 \mathrm{tb} \$ 1.70,100 \mathrm{th} \$ 3.25$

Dried Blood Meal.- This is a highly concentrated form of animal food, rich in albumen and egg producing materials. It is odorless and contains only pure blood. Will make your hens lay, your chicks grow fat and keep your fowls healthy.

$5 \mathrm{tb} 35 \mathrm{c}, 10 \mathrm{tb} \cdot 60 \mathrm{c}, 25 \mathrm{tb} \$ 1.15,50 \mathrm{tb} \$ 2.10$, $100 \mathrm{tb} \$ 4.00$ Granulated Poultry Bone.-The Granulated Bone we offer is made from fresh, green bones, from which the moisture and grease have been taken, leaving nothing but the phosphates, lime, and protein, the only food values of bone, green or dry. $5 \mathrm{mb} 20 \mathrm{c}, 10 \mathrm{tb} 35 \mathrm{c}, 25 \mathrm{mb} 75 \mathrm{c}, 50 \mathrm{mb} \$ 1.35,100 \mathrm{mb} \$ 2.50$

CHARCOAL. - No poultryman can afford to be without charcoal. A little goes a long way, and it is worth its weight in gold to raisers of young chickens. It aids digestion, and promotes the health of brooder chicks to a wonderful extent. The use of charcoal is generally corrective of numerous poultry ills.

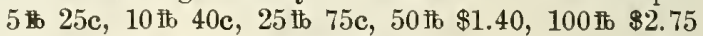

CRUSHED OYSTER SHELLS.-Crushed Oyster Shells to a large extent will supply the necessary material for grinding food, and at the same time furnish lime for the egg shells. They should be kept continually before the fowls, trusting to them to eat the amount needed rather than mixing the shells with food.

5 tb $10 \mathrm{c}, 10$ 范 $15 \mathrm{c}, 25 \mathrm{tb}$. $25 \mathrm{c},-50 \mathrm{lbs}, 40 \mathrm{c}, 100 \mathrm{lbs} .70 \mathrm{c}$

MICO-SPAR CUBICAL GRIT.-Superior to all other Grits. It is the best digester, and retains its cubical form until worn out. Hen and chick

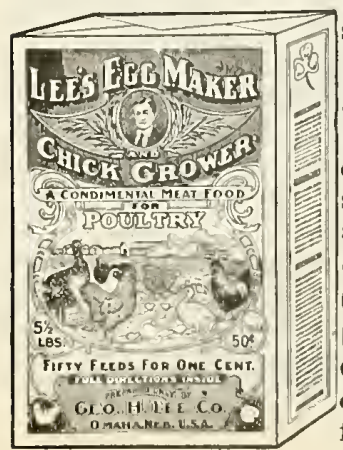
size. 5 lbs. $10 \mathrm{c}, 10 \mathrm{lbs} .15 \mathrm{c}, 25 \mathrm{lbs} .25 \mathrm{c}, 50 \mathrm{lbs} .45 \mathrm{c}, 100 \mathrm{lbs} .75 \mathrm{c}$ Lee's Egg Maker is largely granulated blood (deodorized), one pound of which is equal to 16 pounds of fresh beef, and with an actual tested protein feeding value in excess of 40 per cent. Feed it to hens and pullets and the result will be maximum egg yield, strong birds, glossy coats and bright eyes. Fed to chicks, they will be stronger, grow faster, and mature 2 to 4 , weeks earlier. $2 \frac{1}{2}$ lb. pkg. $25 \mathrm{c}$

GERMOZONE. A germicide, a borrel regulator, the best preventive and cure for Roup, Cholera, Colds, Bowel Complaint, Chicken Pox, etc. Equally good for little chicks or older fowls. Given twice a week in drinking water, keeps fowls healthy.

Tablets or Liquid, 50 cents

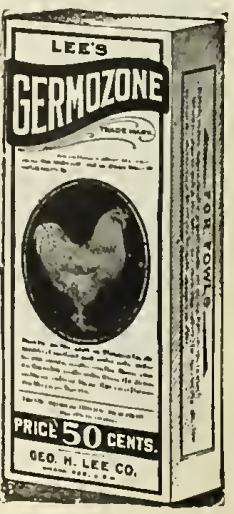




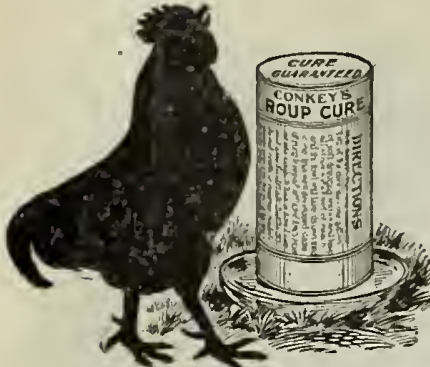

and for canker in pigeons.
CONKEY'S ROUP CURE. Conkey's Roup Cure positively cures roup in all of its forms. It is simply placed in the drinking water and the chicken takes its own medicine without knowing it. Coming into contact with the head and mucous membranes it kills the germs at once. It is equally effective for turkeys

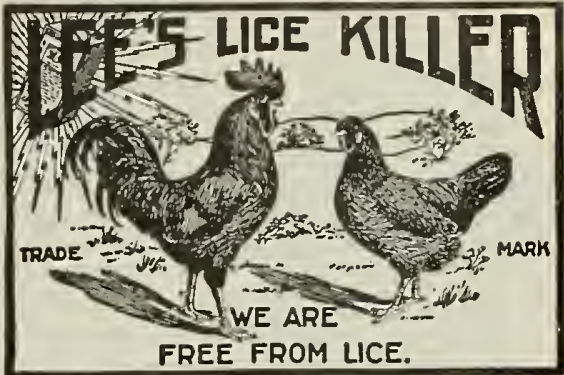

CONKEY'S CHOLERA CURE.-This is a positive cure for bowel trouble, indigestion, diarrboea, dysentery, cholera, etc., in fowls both old and young. It tones up the system and puts the flock in excellent condition.

Price 25c and 50c

Lee's Lice Killer. Lee's Lice Killer is a liquid preparation for destroying lice and mites on chickens, hogs and other stock. It was especially designed for killing lice and mites on chickens and hogs without the necessity of handling, dipping, dusting or greasing fowls or animals. The odor, gas or vapor given off by it kills the insects without touching them with the fluid itself. It is perfectly safe to use as directed.

Quart 35c, 2 quarts 60c

CONKEY'S HEAD.LICE OINTMENT.-Head Lice annually kill thousands of little chicks. Old hens and little chicks should be gone over carefully, and whenever found, these lice should be gotten rid of without delay. Conkey's Head Lice Ointment is a carefully prepared, nicely perfumed, non-poisonous article, which is instant death to these murderous insects, but perfectly harmless to chicks.

3 -ounce tin $25 \mathrm{c}$

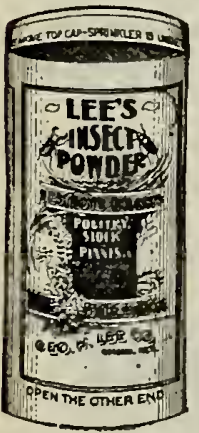

LEE'S INSECT POWDER.-Kills chicken lice, plant lice, roaches, cabbage worms, etc. It is of especial value for use on little chicks and setting hens. Where an insect powder is desired use Lee's. There is none better, and being prepared in $1 \frac{1}{4}$ pound sprinkler-top cans, it is very convenient for use. A large package of the best powder, 25c THE PRAIRIE STATE FOUNTAIN.-The water runs from the can into the basin as the fowls drink, so that the supply is always kept fresh and cool. The chicks cannot get into the basin to foul the water or to drown and will not roost on the top. They are easily cleaned, are light and durable, and will not freeze and burst in winter. 1-qt. 20c, 2-qt. 30c, 1-gal. 40c, 2-gal. 50c STONEWARE FOUNTAIN.-For anybody who desires a stoneware drinking fountain, these founts are not

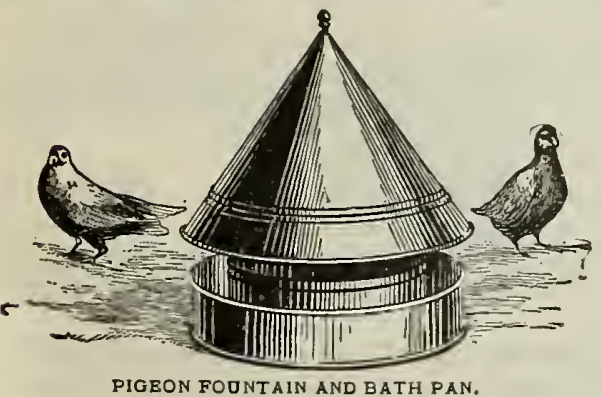

PIGEON FOUNTAIN AND BATH PAN.

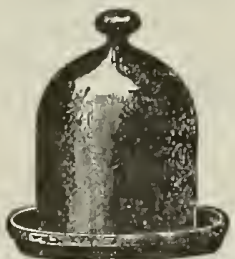

STONEWARE FOUNT.

xcelled for poultry or pigeons. They keep the water cool and clean, and are so manufactured that it is im. possible for chickens to get wet or drown while using them. They are easily filled and never tip over.

1 -quart 20c, 2-quart $30 \mathrm{c}, 4$-quart $40 \mathrm{c}$

PIGEON FOUNTAIN AND BATH PAN.-Made from best galvanized iron and will last for years. Keeps the birds clean healthy and happy. 14 inches, each $\$ 1.50$

PRAIRIE STATE FEED TROUGHS.-A convenience and a food-saving appliance. The chickens cannot get into the troughs to scratch the feed out, but stand along in a row and eat their feed the same as cattle eat hay out of a rack. They are low in price and first class in every respect. Made of bass wood. 18 in. $12 \mathrm{c}, 24$ in. $18 \mathrm{c}, 30$ in. $25 \mathrm{c}$ SWINGING POULTRY FEED TRAY.-Saves all waste of food Hens cannot scratch food out nor dirt in. Weight of hen tips the tray and throws her off. Upper rod tips up also if ben tries to roost on it. Legs fasten anywhere. $18 \mathrm{in} . \$ 1.00$

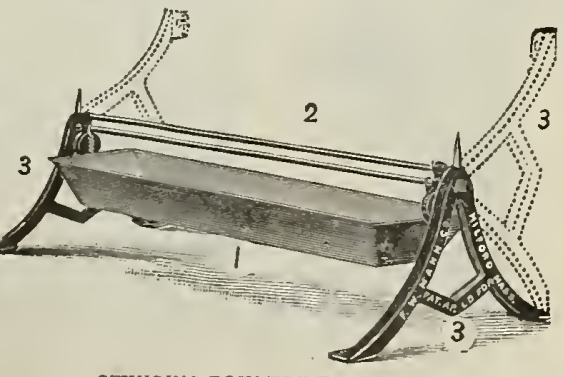

SWINGING POULTRY FEED TRAX. 

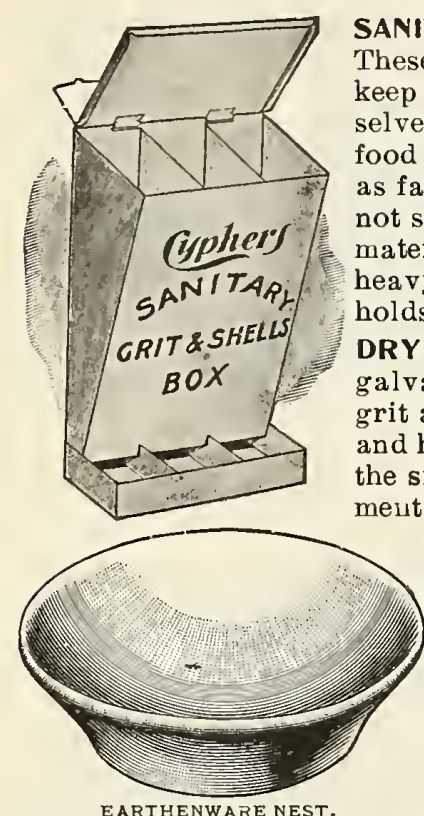

SANITARY GRIT AND SHELLS BOX.-

These boxes are a necessity to all who keep poultry, and they soon pay for themselves. They are automatic feeders, the food working down into the feeding spaces as fast as the fowls eat it. The fowls cannot scratch the feed out, thus saving the material. It has three spaces; made of heavy galvanized iron. Hangs on nail; holds four quarts.

Price 50c

DRY FOOD HOPPER.-This is a strong, galvanized iron feed box, similar to the grit and shell box, except that it is larger and has but two compartments, one twice the size of the other. The larger compart-

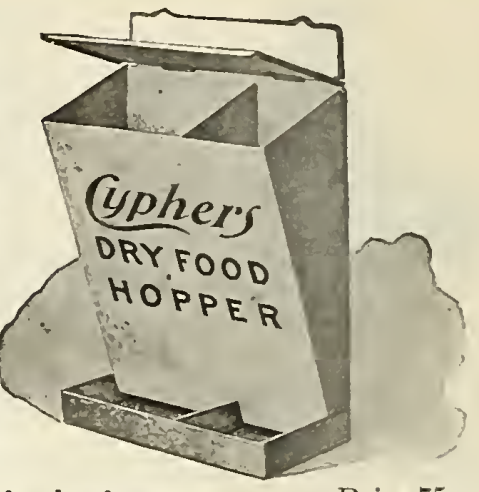
meut is intended for grain, the smaller for beef scraps.

Price $75 \mathrm{c}$

EARTHENWARE NESTS.-Made of very highgrade clay, terracotta in color, well formed in design and of superior finish. Diameter, eight inches.

Each $15 \mathrm{c}$

WIRE HENS' NESTS.-These nests are strongly made of heavy japanned steel wire and will last a lifetime. There is no room for lodging of lice or vermin of any kind; they are easy to keep clean and are far superior to wooden boxes. They are intended to be fastened to the wall with screws or screw hooks.

NEST EGGS.-Porcelain. The eggs are finest white flint glass.

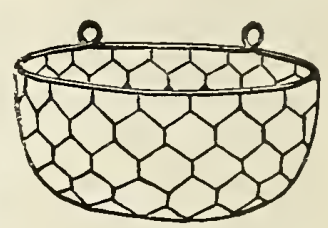

WIRE HENS' NESTS.

2 for $5 c$, dozen $25 \mathrm{c}$

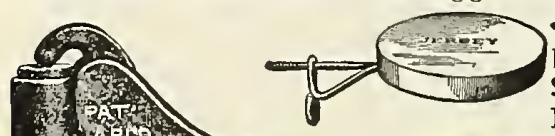

JERSEY PIGEON PERCH.-Of seasoned maple and coppered steel wire. Ea. 6c, doz. 60c SPRING LEVER POULTRY PUNCH.-Spring Lever Poultry Punch is the handiest punch now on the market. Will cut a clean clear hole, which will not grow together. It is durable and never tears the web. Each $25 \mathbf{c}$

PHILADELPHIA POULTRY MARKER.-Made in two sizes, one for chicks and one for adult fowls. Each $25 \mathrm{c}$ EGG TESTER.-This tester fits any No. 2 lamp burner and makes a strong powerful light, so that any person can easily determine whether eggs are fertile or not. Each 25c IMPROVED CHAMPION LEG BANDS.-This is a well known leg SPRING LEVER PUNGH.

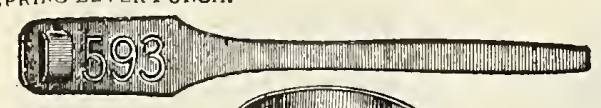
from one thin strip of aluminum, and

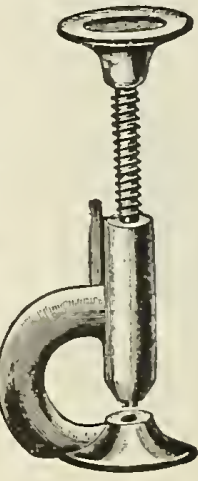
used by hundreds of successful breed-PHILADELPHIA MARK. ers and exhibitors. They are adjust-

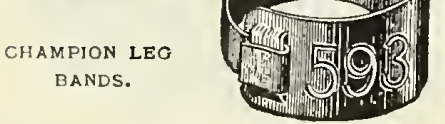

able to fit any fowl, and

being held by a double lock

it is impossible for them to

come off. $12,15 \mathrm{c} ; 25,30 \mathrm{c}$ $50,50 \mathrm{c} ; 100,80 \mathrm{c}$

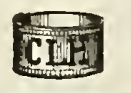

1902 D. B. 175
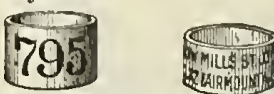

Lurariguris

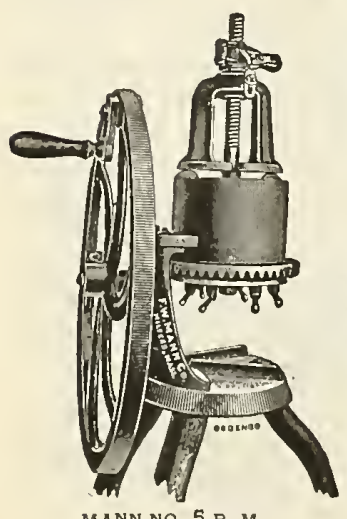

MANN NO, 5 B. M.

PIGEON BANDS.-By the use of ad-

PIGEON BANDS.

dress bands a bird will always wear the name and address in full of the fancier by whom it was bred. No homer breeder or flyer should be without them. Open Aluminum Bands.-Plain or Numbered only, dozen 25e, 25 for 40c Seamless ALUMindm Bands.-Plain, Year and No., or Year and Initials, dozen $25 \mathrm{c}, 100 \$ 1.90$

With Full Name and Address, dozen 40c

MANDY LEE THERMOMETERS.-Incubator, each 75c Brooder, each 5vc MANDY LEE HYGROMETER. Each $\$ 2.50$

Mann's Green Bone Cutters. Easiest to fill. Easiest to clean. Easiest to turn. Warranted against breakage. Guaranteed to give satisfaction. Never out of order. No. 5 B. M.................. $\$ 10.40$ No. 5 B. Same as 5 B. M., except has no stand; mount on table.... 8.00 No. 5 C. Same as 5 B., except has crank instead of balance wheel.. $\quad 6.00$ No. 7. The open cylinder device admits of easy access to the knives

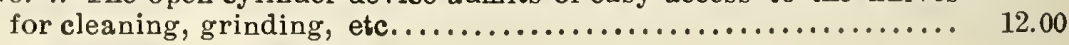




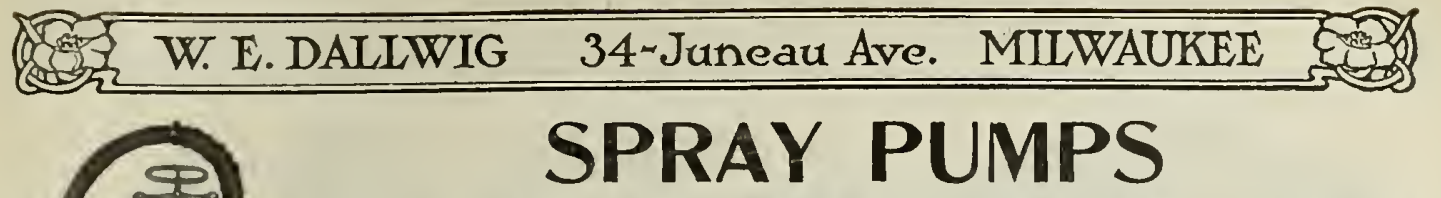

The matter of spraying is each year becoming of greater importance. It is no longer an open question whether spraying is profitable, but on the contrary, the overwhelming evidence of the last few years proves beyond doubt that planters cannot afford to neglect this method of protecting their crops and trees

We have compiled a booklet on "Spraying and Spray Pumps", which tells when and how to spray and what material to use against the various insect pests and fungus diseases. Copies may be had without charge.

For successful spraying a first class equipment is necessary. In the machines offered on this page, every known method and every known improvement have been combined to make them the best of their kinds. Their efficiency and durability are the result of mechanical perfection, not accident.

AUTO.SPRAY NO. 1. Consists of a reservoir of about 4 gallons capacity, made of heavy material, either brass or galvanized steel, as ordered. In this tank is inserted and locked a brass air pump which may be attached or detached by the simple shift of the cam. With this pump air is compressed on top of the solution. After the pressure is generated the operator has nothing to do

ADTO-SPRAY NO. 1. but direct the spray. A few strokes of the plunger will compress enough air to operate the machine for several minutes, and two pumpings will discharge all of the contents.

1A, Brass Tank, with Stop-Cock.......... \$6.75

1B, Brass Tank, with Auto-Pop.......... 7.65

1C, Galvanized Tank, with Stop-Cock...... 4.50

1D, Galvanized Tank, with Auto-Pop...... $\mathbf{5 . 4 0}$

Brass Extensions, 2 ft. lengths........... $\quad .45$

Two-Row Attachment................. 1.35

THE BRANDT SPRAYER. The tank is made of heavy brass or of galvanized steel and will not rust or corrode. Capacity 3 gallons. Filler plug and connections made of brass. The nozzle is made to work with a combination of liquid and air, giving a fine mist-like spray, sent out with great force.

No. 2, Galvanized Tank, with Shut-off Nozzle $\$ \mathbf{\$ 5 . 0 0}$

No. 3, Brass Tank, with Shut-off Nozzle..... $\mathbf{6 . 7 5}$

Double Nozzle \$1.50 Tree Nozzle, $3 \mathrm{ft}$.... 1.50
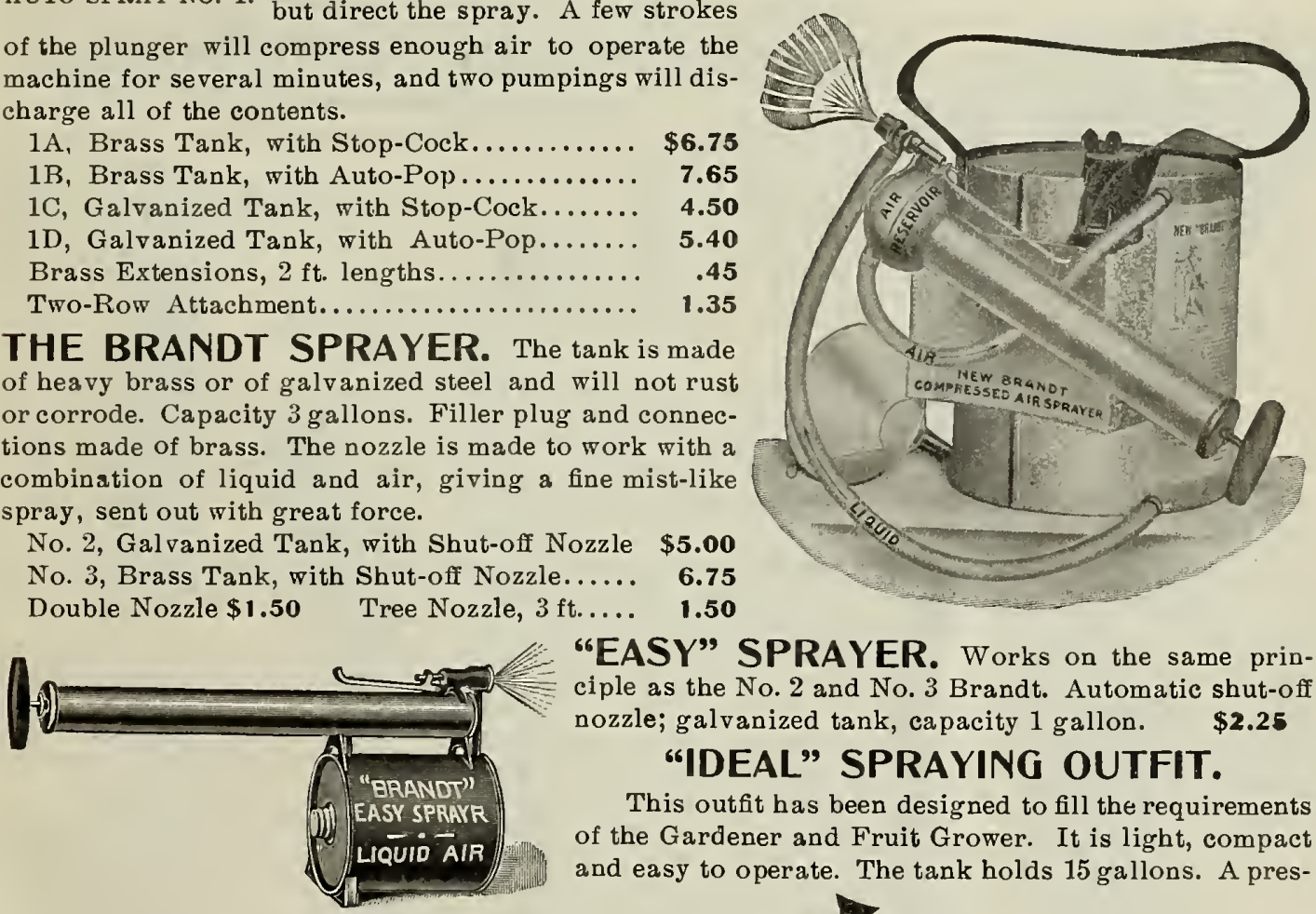

"EASY" SPRAYER. Works on the same principle as the No. 2 and No. 3 Brandt. Automatic shut-off nozzle; galvanized tank, capacity 1 gallon.

$\$ 2.25$

\section{"IDEAL" SPRAYING OUTFIT.}

This outfit has been designed to fill the requirements of the Gardener and Fruit Grower. It is light, compact and easy to operate. The tank holds $\mathbf{1 5}$ gallons. A pres-

sure of 150 pounds can easily be maintained. A mechanical agitator keeps the liquid well stirred Equipment includes: 10 feet $\frac{g}{3}$ in. Pressure Hose 10 feet Pipe Extension, in 3 pieces; $1 \mathrm{~T}$ Handle Shut-off cock; 1 "Ideal"' Nozzle.

$\$ 20.00$

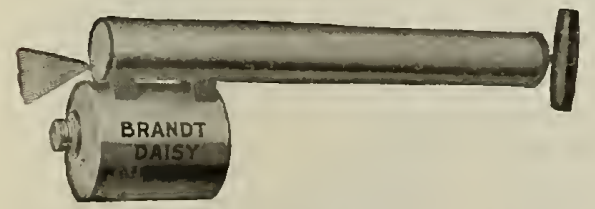

DAISY SPRAYER, Sprays on both strokes, for ward and return. 1 quart galvanized.

RAPID SPRAYER. Double jet; 1 qt. gal.

MISTY SPRAYER. 1 quart tin reservoir. $\quad .50$

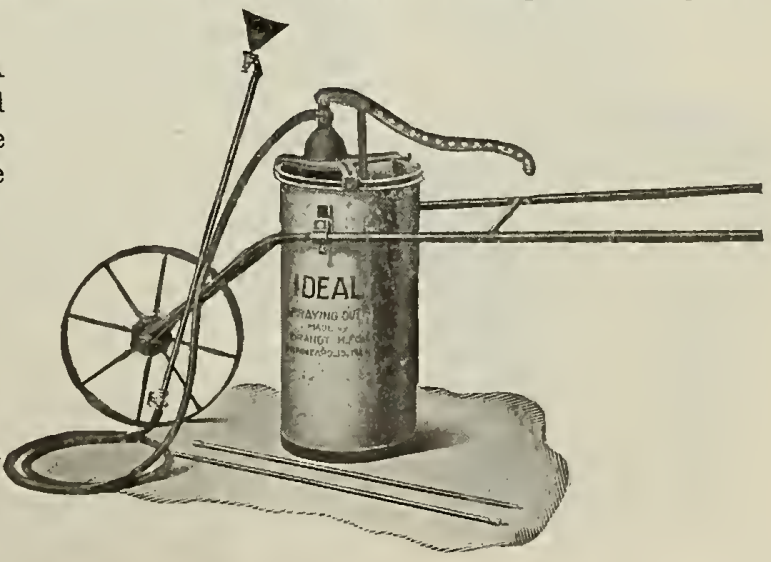



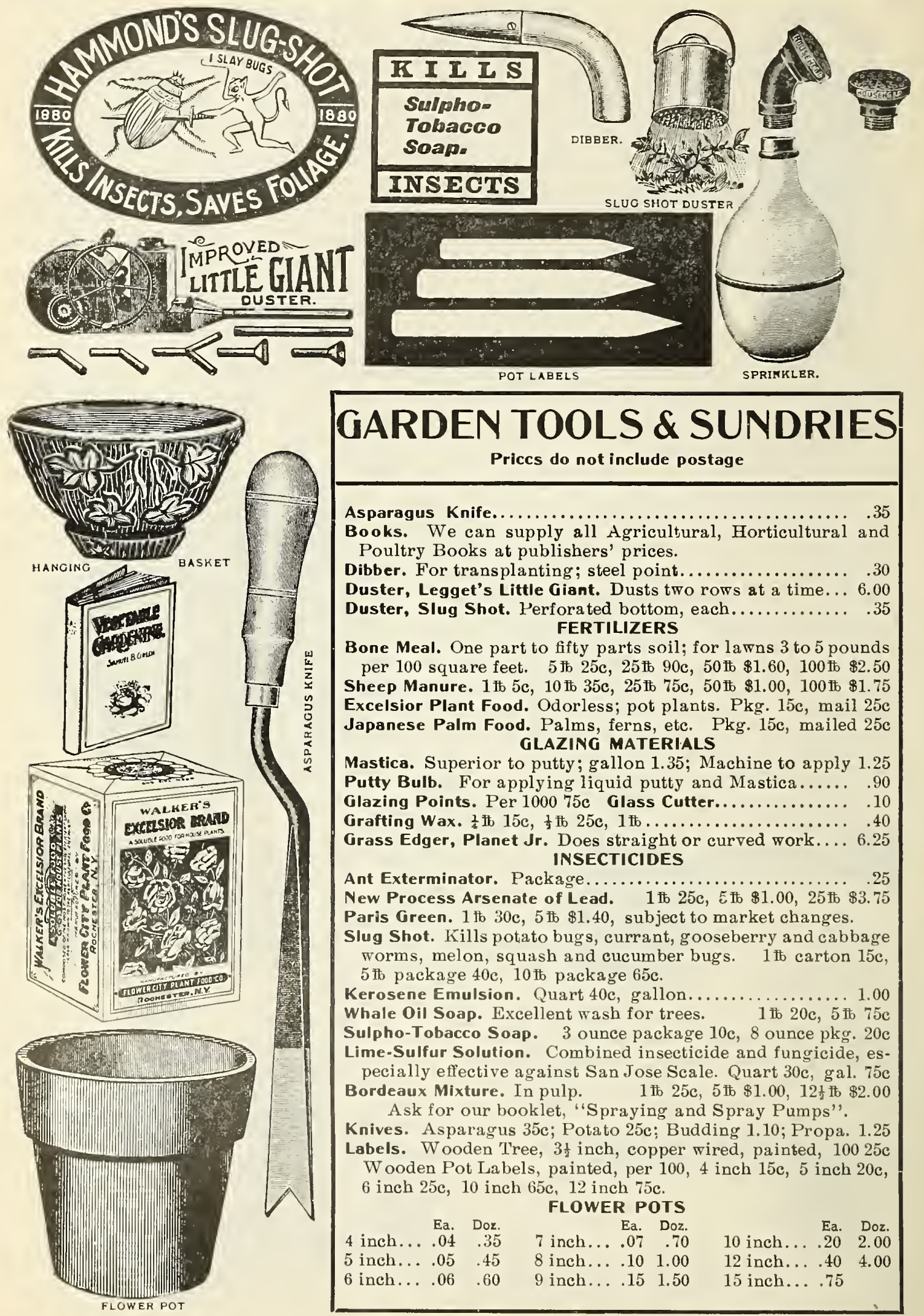

\section{GARDEN TOOLS \& SUNDRIES}

Priccs do not include postage

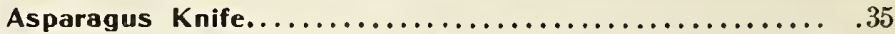

Books. We can supply all Agricultural, Horticultural and Poultry Books at publishers' prices.

Dibber. For transplanting; steel point................30

Duster, Legget's Little Giant. Dusts two rows at a time... 6.00

Duster, Slug Shot. Yerforated bottom, each.............35 FERTILIZERS

Bone Meal. One part to fifty parts soil; for lawns 3 to 5 pounds per 100 square feet. $5 \mathrm{fb} 25 \mathrm{c}, 25 \mathrm{tb} 90 \mathrm{c}, 50 \mathrm{fb} \$ 1.60,100 \mathrm{fb} \$ 2.50$ Sheep Manure. $1 \mathrm{fb} 5 \mathrm{c}, 10 \mathrm{fb} 35 \mathrm{c}, 25 \mathrm{fb} 75 \mathrm{c}, 50 \mathrm{fb} \$ 1.00,100 \mathrm{fb} \$ 1.75$ Excelsior Plant Food. Odorless; pot plants. Pkg. 15c, mail 25c Japanese Palm Food. Palms, ferns, etc. Pkg. 15c, mailed 25c GLAZING MATERIALS

Mastica. Superior to putty; gallon 1.35; Machine to apply 1.25 Putty Bulb. For applying liquid putty and Mastica..... .90 Glazing Points. Per 1000 75c Glass Cutter.............. 10 Grafting Wax. $\frac{1}{4} \mathrm{tb} 15 \mathrm{c}, \frac{1}{9} \mathrm{tb} 25 \mathrm{c}, 1 \mathrm{tb} \ldots \ldots \ldots \ldots \ldots \ldots \ldots .40$ Grass Edger, Planet Jr. Does straight or curved work... 6.25 INSECTICIDES

Ant Exterminator. Package...................... 25

New Process Arsenate of Lead. $1 \mathrm{ib} 25 \mathrm{c}, \Sigma_{\mathrm{ib}} \$ 1.00,25 \mathrm{tb} \$ 3.75$ Paris Green. $1 \mathrm{fb} 30 \mathrm{c}, 5 \mathrm{fb} \$ 1.40$, subject to market changes.

Slug Shot. Kills potato bugs, currant, gooseberry and cabbage worms, melon, squash and cucumber bugs. $1 \mathrm{tb}$ carton $15 \mathrm{c}$, $5 \mathrm{tb}$ package $40 \mathrm{c}, 10 \mathrm{tb}$ package $65 \mathrm{c}$.

Kerosene Emulsion. Quart 40c, gallon.............. 1.00 Whale Oil Soap. Excellent wash for trees. $\quad 1$ ib $20 \mathrm{c}, 5$ ib $75 \mathrm{c}$ Sulpho-Tobacco Soap. 3 ounce package 10c, 8 ounce pkg. 20c Lime-Sulfur Solution. Combined insecticide and fungicide, especially effective against San Jose Scale. Quart 30c, gal. 75c Bordeaux Mixture. In pulp. $\quad 1 \mathrm{tb} 25 \mathrm{c}, 5 \mathrm{fb} \$ 1.00,12 \frac{1}{2} \mathrm{tb} \$ 2.00$ Ask for our booklet, "Spraying and Spray Pumps".

Knives. Asparagus 35c; Potato 25c; Budding 1.10; Propa. 1.25 Labels. Wooden Tree, $3 \frac{3}{2}$ inch, copper wired, painted, $10025 \mathrm{c}$ W ooden Pot Labels, painted, per 100, 4 inch 15c, 5 inch 20c, 6 inch 25c, 10 inch 65c, 12 inch 75c.

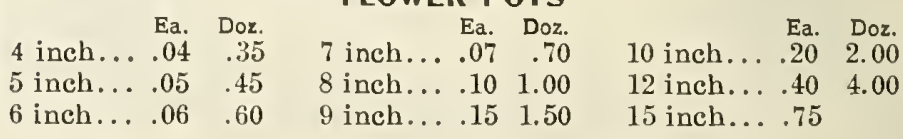



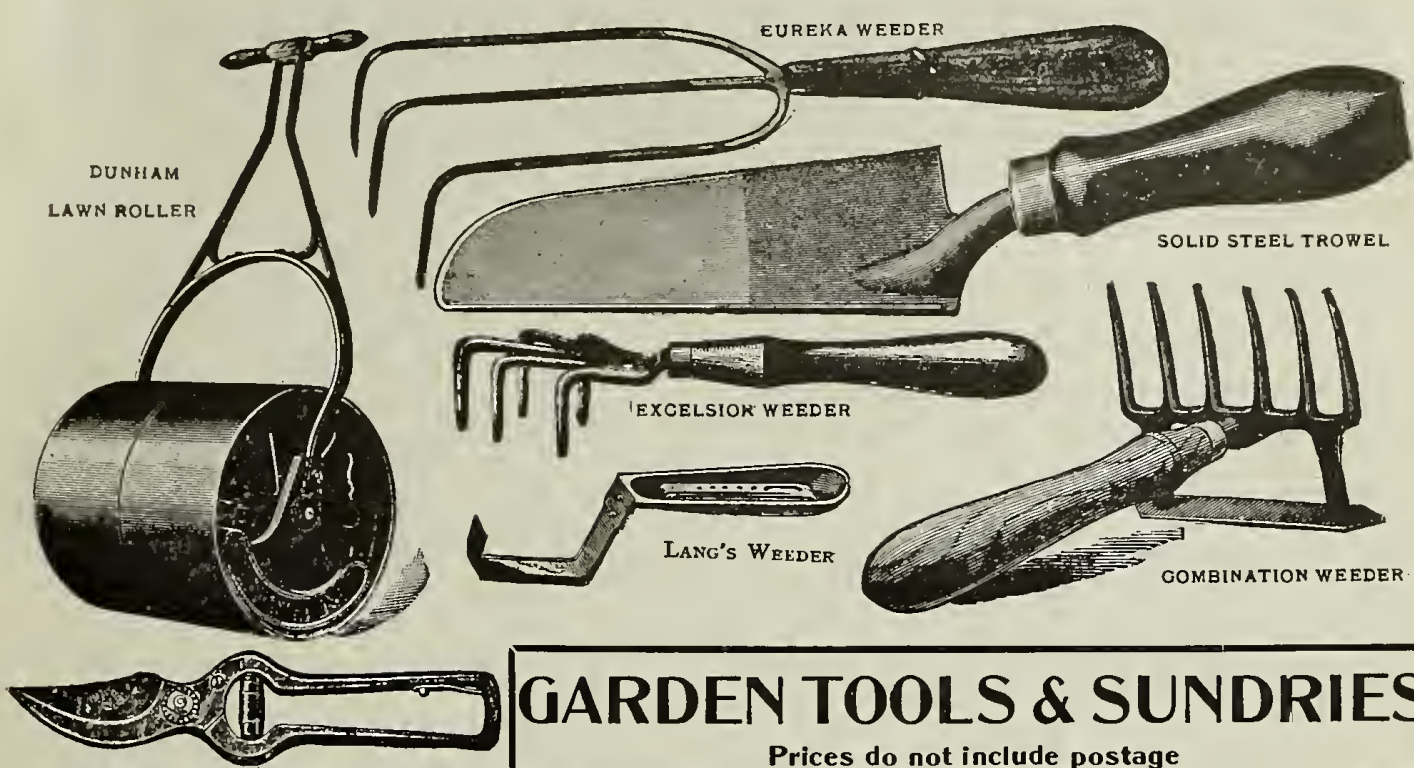

GARDEN TOOLS \& SUNDRIES

Prices do not include postage

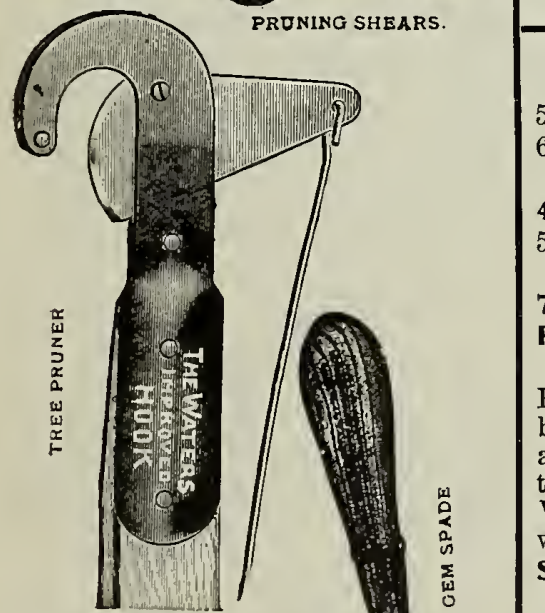

\section{BULB AND FERN PANS}

5 inch... Ea. Doz. 7 inch... Ea. Doz. 10 inch... Ea. Doz.

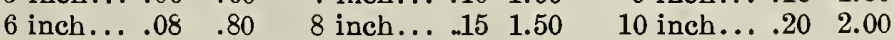
SAUCERS

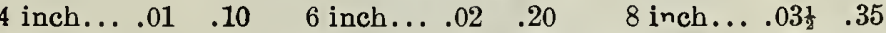

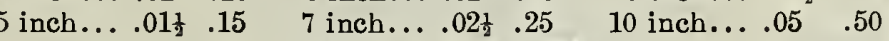

$\begin{array}{lllll}7 \text { inch... .20 } 2.00 \quad 8 \text { inch... } & .25 & 2.50 & 9 \text { inch... .25 } & 2.50\end{array}$

Raffia. Best tying material. Pound................ .25

\section{DUNHAM LAWN ROLLERS}

Run 44 per cent easier than any other through the use of rollerbearings, and high carbon steel, perfectly round and smooth axles-as used in automobile construction. In one, two and three sections, weighing from 150 pounds upward. The "W aterWeight" Roller can be filled with water or sand to any desired weight, can also be had in one or two sections. Ask for prices. Shears. German Pruning, $6 \frac{1}{2}$ inch 1.10, $7 \frac{1}{2}$ inch 1.25, $8 \frac{1}{2}$ inch 1.35 California Pruning, 9 inch......................65

Sheep, with thumb guard. For trimming grass........ .35

Sprinkler, Scollay's Rubber. Large size 90c, by mail..... . 1.00

Medium size 75 , by mail.................... .85

Stakes, Cane. $6-8$ feet long. Dozen 25 c, $100 \ldots \ldots \ldots \ldots \ldots 1.00$

Thermometers. Tin Case, 8 inch, each 20 c, 6 for....... 1.00

Hot Bed, brass point, wooden frame, each.......... 2.00 Imported German, glass, for propagating and hot beds .35 Incubator Thermometer 75c. Brooder Thermometer.. .50

Tree Pruner, Water's. Length of pole, 6 feet, 75c; 8 feet, 90c; 10 feet, $1.00 ; 12$ feet, 1.10

\section{TROWELS}

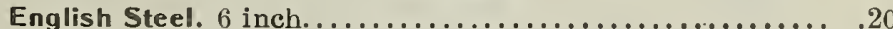

Solid Tempered Steel. Drop Shank Sockets............ . .50

Transplanting Trowel. Blade narrow and deeply curved... .20

Gem Spade. Three Prong Hand Forged Steel............ . 30

Turf Edger..................................... .

\section{WEEDERS}

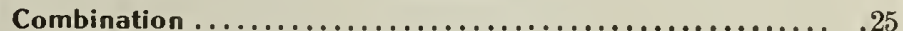

Eureka. Three Prong Hand Forged Steel............... . 35

Long Handled Eureka. With 2-ft. handle............. .50

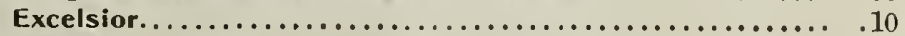

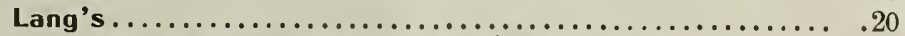

Mehler's Handy Gardener. Hoe, Rake, Weeder and Cultivator in one; handle $4 \frac{1}{8}$ feet long...................... 85 


\section{"PLANET JR." FARM AND GARDEN TOOLS}

Space will not permit our showing and describing all of the "Planet Jr." tools but we will send a fully illustrated catalogue FREE FOR THE ASKING to any who desire it, and we can supply promptly anything ordered. "Planet Jr." goods are standard machines, the best on the market. In sending your orders to us, you can rely on getting bottom prices.

\section{"PLANET JR." No. 4.}

COMBINED HILL. AND DRILL SEEDER, SINGLE WHEEL HOE, CULTIVATOR AND PLOW.

THIS admirable tool combines in a single convenient imple. 1 ment a capital hill dropping seeder, a perfect drill seeder, a single wheel hoe, a cultivator. and a plow. It holds two quarts and as a seeder it sows in a continuous row, or drops in hills at five different distances. It is thrown out of gear by simply raising the handles. The index is accurate, simple and easily set. The drill is detached and the tool frame substituted by removing but one bolt. It then becomes a single wheel hoe, garden-plow or cultivator. It is useful almost every day of the season, at every stage of garden work. With this one implement the small farmer can do practically all the work in his small crops.

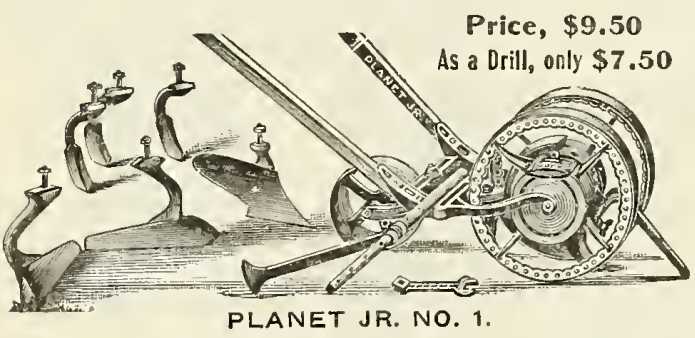

\section{COMBINED DRILL SEEDER AND WHEEL HOE, CULTIVATOR ANU PLOW.}

THIS has been long the most popular combined too 1 made. From a drill it is changed to its other uses by removing two bolts. when hoes, etc., can be quickly attached. It is an excellent seed sower, a first-class wheel hoe, an excellent furrower. an admirable whee cultivator, and a rapid and efficient garden plow. It is a practical, every-day time and labor saver, and a grand remedy for backache.

\section{No. 12 DOUBLE WHEEL HOE.} THIS perfected wheel hoe is invaluable for use in all 1 small crops. Its variety of work is almost incredible. Changes and adjustments of the tools are made with the greatest quickness. It has 11-inch wheels, which can be set at four different distances apart; the frame is malleable, with ample room for tool adjustment and can be set three different heights. The handles are adjustable at any height, and, being attached to the arch, are undisturbed in making shange frame permits the tools to be changed without removing the nuts.

PLANET JR. NO. 12.

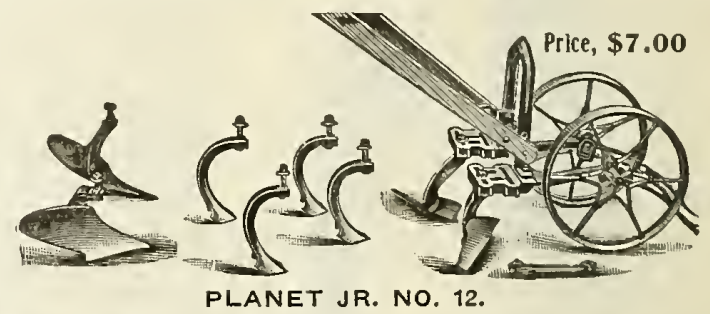

PLANET JR. No. 13 DOUBLE WHEEL HOE. With Hoe Blades only, price $\$ 4.75$

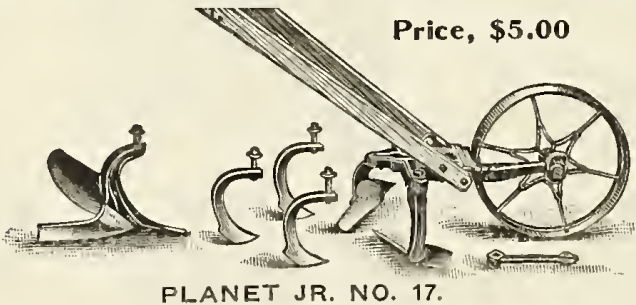

PLANET JR. TWELVE TOOTH HARROW

Gardeners chltivate better than formerly. It has been found to pay best. With the Twelve-Tooth Harrow you go as deep or shallow as you like, come up close to row without injuring plants, cut out all the weeds, stir the soil and mellow and fine it as with a garden rake. You widen and narrow as you please between 12 and 32 inches. It's a special favorite with strawberry growers, market gardeners and truckers.

A strawberry runner cutter consisting of a 10-inch flat steel disc mounted on an outrigger. Extra. Price\$1.85.

Beet Hoes for hoeing beets and all crops in rows from 15 to 30 inches. They do admirable work, leaving the ground level. Price, per pair, \$1.40.

\section{No. 17 SINGLE WHEEL HOE.}

THIS latest and best single wheel hoo has a very full set of tools. It has 11-inch wheel, with broad
face, is very light, strong a nd easy running. It has adjustable handles and quick-change frame.

\section{No. 18 Planet Jr. Single Wheel Hoe.} WITH HOE BLADES, ONLY $\$ 3.50$.

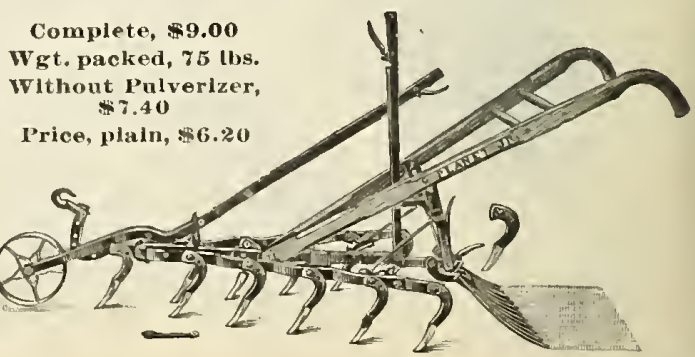


